University of Michigan Law School

University of Michigan Law School Scholarship Repository

\title{
Review of administrative acts : a comparative study of the doctrine of the separation of powers and judicial review in France and the United States
}

Armin Uhler

University of Michigan Law School

Follow this and additional works at: https://repository.law.umich.edu/michigan_legal_studies

Part of the Comparative and Foreign Law Commons, Courts Commons, and the Jurisdiction Commons

\section{Recommended Citation}

Uhler, Armin. Review of Administrative Acts: A ComparativeStudy of the Doctrine of the Separation of Powers and Judicial review in France and the United States. Chicago. Callagham \& Company, 1942

This Book is brought to you for free and open access by the Law School History and Publications at University of Michigan Law School Scholarship Repository. It has been accepted for inclusion in Michigan Legal Studies Series by an authorized administrator of University of Michigan Law School Scholarship Repository. For more information, please contact mlaw.repository@umich.edu. 


\title{
MICHIGAN LEGAL STUDIES
}

\author{
REVIEW OF \\ ADMINISTRATIVE ACTS
}

PUBLISHED UNDER THE AUSPICES OF THE UNIVERSITY OF MICHIGAN LAW SCHOOL (WHICH, HOWEVER, ASSUMES NO RESPONSIBILITY FOR THE VIEWS EXPRESSED) WITH THE AID OF FUNDS DERIVED FROM GIFTS TO THE UNIVERSITY OF MichigaN BY WILliam W. COOK 


\title{
MICHIGAN LEGAL STUDIES
}

\author{
Discovery Before Trial \\ George Ragland, Jr.
}

Torts in the Conflict of Laws

Moffatt Hancock

The Amending of the Federal Constitution Lester B. Orfield

Review of Administrative Acts

Armin Uhler 


\section{REVIEW OF}

ADMINISTRATIVE ACTS

A Comparative Study of the Doctrine of the Separation of Powers and Judicial Review in France and the United States

by

\section{Armin UhLer $=$}

J. U. D. (LEIPZIG) ; S. J. D. (MICHIGAN)

Foreword

by

E. BLYTHE STASON

Ann Arbor

The University of Michigan Press

Chicago

Callaghan \& Company

I 942 
Copyright, 1942 BY

University of MichigaN 
To

Dean Emeritus Henry M. Bates 


\section{Foreword}

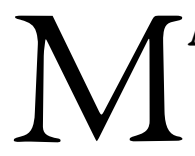

ANY helpful studies of administrative law and procedure have been brought to the light of day the vineyard, and the law review articles and monographs produced by them have been legion. Many public and quasipublic groups have delved into the subject. A brief glance will show the extent and seriousness of the interest.

In 1929 the British "Committee on Ministers' Powers" was appointed by the Lord High Chancellor and was directed to study delegated legislative and quasi-judicial powers in England. The Committee filed its notable report in 1932-a report regarded as a pioneer among contemporary cooperative studies in the field.

Beginning in 1933 and continuing to date, the American Bar Association has maintained a Special Committee on Administrative Law. This committee, confining its attention to the Federal administrative system, has submitted a series of annual reports containing a wealth of useful information. After years of diligent labor the committee finally prepared and, with the authority of the Association, sponsored before Congress the much-discussed Logan-Walter Bill, a measure which, after a stormy career, was passed by Congress, but died by Presidential veto. The American Bar Association has been active in yet another direction. In 1937 the Association Section on Judicial Administration established a section Committee on Administrative Agencies and Tribunals, with direction to study the administrative law of the forty-eight states of the Union. This Committee prepared and filed two instructive annual reports dealing with the subject matter under its jurisdiction. Furthermore, the Committee drafted a bill 
designed to serve as a model act for use by the several states, to be followed by them if desired in drafting statutes concerning state administrative procedures. This bill has now been submitted to the National Conference of Commissioners on Uniform State Laws for consideration in the hope that it will ultimately be promulgated as one of the national Conference Uniform Acts.

Still another manifestation of the current interest in the subject appears in the recently filed report of the Attorney General's Committee on Administrative Procedure, a committee appointed by the Attorney General of the United States on request of the President. For two years prior to reporting, the Committee and its research staff studied in detail the principal Federal administrative agencies. Its report represents the culmination of these studies. Moreover, the Report is destined to accomplish a more valuable result than mere occupancy of shelf space in libraries. It is accompanied by two proposed bills embodying notable legislative recommendations regarding administrative procedure. The bills have now been introduced into the United States Senate where they are known as S. 674 and S. 675. S. 675 has the support of the entire Attorney General's committee-S. 674, on the other hand, was prepared and submitted by a minority group, but it now bears the stamp of approval of the House of Delegates of the American Bar Association. It purports to establish in legislative form a Code of Fair Standards of Administrative Procedure, so far as it is possible to create such standards by legislation.

From this brief review of some of the principal manifestations of ferment in the field, it is apparent that administrative agencies and their procedures are being subjected to a vast amount of careful scrutiny by many well-qualified persons and groups. Moreover, it is by no means an overstatement to assert that all who have studied the subject objectively 
have found ample room for improvement. The end has not yet been reached.

In the midst of all of the ramifications of this dynamic subject, no single phase has proved of greater significance or interest than the power and extent of the right of the courts to review administrative action. No phase of administrative law has produced a more extensive literature. None has occasioned more careful thought by members of the bench, the bar, and the teaching branch of the profession. This intensity of interest need not be deemed unusual or extraordinary, for judicial review is one of the essential checks and balances.

Therefore, Mr. Uhler's monograph, comparing the history and operation of the doctrine of separation of powers in France with that in this country, so far as relates to judicial review of administrative acts, penetrates to the heart of one of the most significant areas of administrative law. The line of demarcation between the power of administration and that of the courts is, in the long run, determined not by immediate case to case necessity, but by the broad proposition that a free country can continue to be free in the best sense only if administrative usurpation is adequately held in check. With this thought in mind, Mr. Uhler's sketch of French juristic history compared with our own is most timely as well as most illuminating. In French legal history, as he so carefully points out, judicial review has passed from a stage, prior to the Revolution, of potent judicial control over administration, through a stage of minimized control, into the present regime in which the rule of law is again generously employed in the protection of private rights against administrative error-first a high state of judicial control, then, for political reasons, a low state of judicial control, and now again a relatively high state. The pendulum swings to and fro, and in France it has measured three half-strokes.

Compare French juristic history with that of this country. In post-Revolutionary days, fear of legislative power domi- 
nated our political thinking. Consequently, when our theory of government was formulated, the courts were placed on a parity with the legislative and executive branches in order that the checks and balances introduced thereby might neutralize the likelihood of disastrous consequences. Today, in the midst of a dynamic program of world change and American social reform, judicial power is being severely criticized, and in many quarters efforts are being made with substantial measure of success to subordinate the judiciary to the administration, especially when legal questions arising under current programs of social reform are involved. Courts are deemed by proponents of these efforts to stand in the way of needed social and political progress. Fortunately, with us this has taken place without revolution. With us the pendulum has up to now swung just two half-strokes; but, if the teachings of history are to be believed, in due course the pendulum will swing back again, just as surely as it did under the French Republic. The Courts will in the long run occupy a position of equality and independence, exemplifying the supremacy of the law in an orderly and balanced polity. Indeed, this must happen if the country is to remain free. So, in thinking of judicial review of administrative decisions, it is wise to regard it as a most important feature of the theory of checks and balances in our juristic and governmental scheme-a substantial part of the swinging pendulum. We must continually ask ourselves what is the proper degree of judicial review if a wise balance is to be maintained. That should be our guiding star.

Mr. Uhler has given us a careful and scholarly discussion of judicial review under the French administrative system. Today judicial review in this country is in a state of flux. The recent decision of the United States Supreme Court in the case of The Railroad Commission of Texas $v$. Rowan and Nichols Oil Company ${ }^{1}$ leads us to anticipate a substantial re-

\footnotetext{
${ }^{1} 310$ U. S. 573 .
} 
striction of the doctrine that has been current since I 920 concerning judicial review of constitutional facts. Statutes stipulating that judicial review of facts shall be precluded when "substantial evidence" is found to support administrative decisions are being interpreted variously but with increasing restrictivity. Some of the legislation now before Congress seeks to deal with the ever-present and all-important question of the power of the courts with respect to administration. The end is not in sight. The last word has not been said. Mr. Uhler's comparative study comes at a peculiarly appropriate time.

E. Blythe Stason 


\section{Preface}

7 HE present study was originally inspired by the widespread interest in the doctrine of the separation of

1 powers stimulated by current discussions of vital problems of administrative law. Frequent reference to this doctrine occurs especially in recent legal literature concerned with the relation between the administrative and judicial departments of government. Particular mention may be made of the attention which has been given the doctrine by the Special Committee on Administrative Law of the American Bar Association. However, the allusions to the doctrine in these discussions to prevalent separation of powers in the organization of government have not always been sufficiently discriminating. Mirabeau's warning in the constitutional debates of 1789 in France not to invoke the formula without first carefully ascertaining its true meaning is as timely today as it was then.

It is the object of this study to investigate the content of the doctrine of the separation of powers with a view to establishing the nature and extent of its bearing upon the problem of review of and relief from administrative action. Ultimately, this inquiry seeks to disclose the measure in which the doctrine has become a screen more or less effectively concealing the forces which actually determine the function of judicial control of administrative action.

The plan adopted necessitates an introductory analysis of the doctrine of the separation of powers. In order to fix its meaning, Montesquieu's ideas, so often relied upon, will be briefly reviewed. This will be followed by an examination of the functional value of the doctrine, that is, the historically conditioned place which it came to occupy at an early date 
as a factor in determining the relation of the judiciary to the administration. Particular care has been taken to give a clear presentation of the political conditions preceding the inauguration of a representative government in France. The historical facts of that time are of special interest for an understanding of the different significance of the separation of powers in the France of I789-1940 and in the United States. The full understanding of that difference in significance, in turn, is indispensable for correct appraisal of the developments during this century and a half, as well as for intelligent comparison of the French and American systems of reviewing administrative acts.

The phase of French public law selected for comparison presents many points of uncommon interest at the present time. The droit administratif, developed while France was an outstanding exponent of the doctrine of the separation of powers, has repeatedly been the subject of consideration from the viewpoint of administrative law in this country. However, it has not as yet been explored sufficiently to be capable of serving as a guide in the United States. The large part of this study dealing with the pertinent problems as they present themselves in French law is intended to afford a closer view of the droit administratif, and it is hoped that what has proved an extremely interesting task will indirectly throw fresh light on American administrative law.

One more observation should be made at this time concerning the general nature of the droit administratif. Much of French administrative law is embodied in a long succession of statutes, the first of which were enacted in I 789. But there has also been an impressive body of "common law," developed by the three distinguished courts of the country, the Cour de cassation, the Conseil d'Etat, and that great umpire, the Tribunal des conflits. Their decisions reflect important fluc- 
tuations and trends, particularly in respect to the jurisdiction of the ordinary courts over administrative action. Indeed, the phase of French public law which is the subject of the present discussion is almost entirely governed by rules having their origin in judicial decisions.

In concluding this introduction, allusion is briefly made to the events which have abruptly terminated the evolution of what was until so recently the French administrative system. But the destruction of institutions expressive of democratic ideas cannot impair their enduring intrinsic value.

The author desires to acknowledge his appreciation for the invaluable assistance and encouragement he has received from Dean E. Blythe Stason and Professor Hessel E. Yntema of the University of Michigan Law School. The author also expresses his gratitude to Professor Hobart R. Coffey, University of Michigan Law Librarian, for his assistance in securing foreign material, and to Miss Katherine Kempfer, Associate Editor of the Michigan Law Review, for her cooperation in the preparation of the final draft of the manuscript.

The Michigan Law Review has courteously consented to the republication of that part of the study which appeared in volume 37 of the Review, at page 209, under the title of "The Doctrine of Administrative Trespass in French Law; an Analogue of Due Process."

Armin UhLer

Ann Arbor, Michigan

September, 1940 


\section{Table of Contents}

PAGE

FOREWORD BY E. BLYTHE STASON.............vï

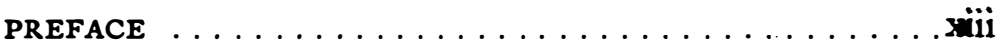

TABLE OF FRENCH CASES ................... XXं

TABLE OF AMERICAN CASES . . . . . . . . . . . . XXXiX

PART I. THE DOCTRINE OF THE SEPARATION OF POWERS .............. I

Chapter I. Development of the Doctrine of the

Separation of Powers in France........ 3

A. The Doctrine of the Separation of Powers as Conceived by Montesquieu............. 3

B. The Historical Background of the Doctrine of the

Separation of Powers in French Law. . . . . . 8

I. The King and the Parlements......... 8

2. Judicial Interference with the Executive.... . Io L

C. The Significance of the Doctrine of the Separation of Powers in Post-Revolutionary French Law. I I

I. The Basic Principle .............. I I

2. Evolution of the Administrative System.... I4

Chapter II. Comparative Significance of the Separation of Powers for Jurisdiction to Review Administrative Acts

PART II. THE REVIEW POWERS OF THE ADMINISTRATIVE COURTS IN FRANCE . . $\quad 29$

Chapter III. Recourse for Excess of Power.... . 3i

A. History of Annulment of Administrative Acts in the Conseil d'Etat................ 3I 
xviii

B. Substantive and Procedural Features of the Recourse for Excess of Power............ 33

I. Grounds for and Nature of the Appeal. .... 33

2. The Subject Matter of the Appeal...... 36

Chapter IV. Review of Administrative Acts on the Merits..................... 38

A. Theoretical Basis of Jurisdiction. ......... 39

I. Authoritative Acts and Acts of Management. . 39

2. The Public Service Criterion ........... . 40

B. Judicial Interpretation . . . . . . . . . 42

I. The Rule of the Blanco Case......... 42

2. Extension and Modification of the Rule of the Blanco Case ................. 46

3. The Public Service Criterion Applied to Contracts ..................... 50

(a) The Thérond Case........... 50

(b) Qualification of the Rule of the Thérond Case ................. 52

4. Later Developments-Commercial and Noncommercial Public Service.......... . 56

Chapter V. A Comparison of Administrative Review and Judicial Review........... 6 6 I

PART III. THE REVIEW POWERS OF THE ORDINARY COURTS IN FRANCE ..... 75

Chapter Vi. Review of Administrative Regula-

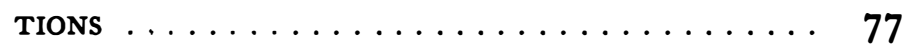

A. The Question of the Legality of Regulations... 77

B. The Intrinsic Nature of Regulations........ 80

C. Effects and Rationale of the Jurisdiction of the Ordinary Courts Over Regulatory Acts...... 
D. The Septfonds Case Compromise. . . . . . . . . 86

E. Conclusion and Comparison............ 88

Chapter Vil. Jurisdiction Over Public OffiCERS $\ldots \ldots \ldots \ldots \ldots \ldots \ldots \ldots \ldots \ldots \ldots \ldots$

A. The Conditions at the Time of the French Revolution ................... 94

B. The Constitutional Guarantee of Administrative Agents of the Year VIII . . . . . . . . . . . 96

C. Repeal of the "Administrative Guarantee"-Interpretation-Consequences ........... IOI

D. Reaction-The Tribunal des Conflits and the Pelletier Case .................. I05

Chapter VIII. Faute Personnelle and Faute de

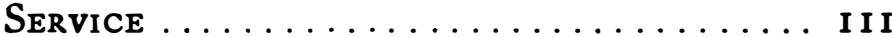

A. Early Period-Laferrière .............. II 3

I. Intent and Magnitude of Error......... I I3

2. Negligence $\ldots \ldots \ldots \ldots \ldots \ldots \ldots \ldots$ I 5

3. Abuse of Power ................ II6

B. Classifications of Jèze .............. I I 8

I. Bad Faith-Gross Error .............. II9

2. Fautes Lourdes . . . . . . . . . . . . . . . I 20

C. Later Developments ................ I 24

I. Duguit-Detachable and Nondetachable Errors ..................... I 24

2. Appleton-Intellectually Discernible Fault. . I25

3. Recent Decisions . . . . . . . . . . . . . I 27

D. Conclusion .................. I30

Chapter IX. The Doctrine of Administrative TRESPASS $\ldots \ldots \ldots \ldots \ldots \ldots \ldots \ldots \ldots \ldots \ldots \ldots \ldots \ldots \ldots \ldots$

A. Is There an Inherent Judicial Power to Protect Persons and Property Against Administrative Encroachments? 
B. The Trespass Concept ............... I 37

I. General Theoretical Considerations....... I 38

(a) Illegality ................ I 38

(b) Usurpation of Power............ I 139

2. Administrative Trespass Defined ........ I4I

(a) Applications $\ldots \ldots \ldots \ldots \ldots \ldots \ldots$ I43

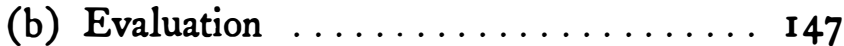

3. The Elements of Trespass Analyzed....... I 50

(a) Illegality-Usurpation and Procedural Irregularity $\ldots \ldots \ldots \ldots \ldots \ldots$ I 50

(b) Invasion of Civil Liberties and Property Rights ................. I 54

Chapter $X$. Recent Applications of the Tres-

Pass Doctrine ................. I 55

A. The Action Française Case ............ I 55

B. Administrative Execution Against Persons and Property ................ I62

I. The Rule of the Saint-Just Case........ I63

2. The Saint-Just Rule and the Action Française Case ...................... I69

C. A Third Element of Trespass-Extent of Invasion ............... I $7 \mathbf{I}$

D. Voie de Fait Distinguished from Faute Personnelle .................... I 73

E. The Significance of the Trespass Doctrine.... I I 74

$\{$ Chapter XI. Comparison and Conclusions ..... I 77 BIBLIOGRAPHY $\ldots \ldots \ldots \ldots \ldots \ldots \ldots \ldots$ I9I

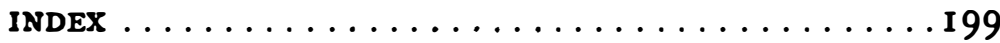




\section{Table of French Cases}

App. = Cour d'appel

Cass. $=$ Cour de cassation

C.d'Et. = Conseil d'Etat

C.d.préf. $=$ Conseil de préfecture

Confl. $=$ Tribunal des conflits

Trib. sup. $=$ Tribunal supérieur

PAGE

Alamichel v. Ville de Vichy, (Cass.) S. I 926.1.2 I 3 ...... 88 Anduran [matter of], (C.d'Et.) D. 1925.3.43 ..161, 162, 169 Anduze v. Maire de Chalabre, (Confl.) Rec. I 879.805 (806). I I4 Arrighi [matter of], (C.d'Et.) Rec. 1936.966, S.

1937.3.33(37), noted 54 R.D.P. (1937) $370 \ldots \ldots \ldots 83$ Bailly v. Carques, (Conf.) D. I 1918.3.I(4) ....... I60, I 72 Baldy v. Préfet de Saône-et-Loire, (C.d'Et.) D. I920.3.25 . I6I Béguin v. Choquet, (App. Paris) Gaz. Pal. 1935.2.257 (258),

mentioned 52 R.D.P. (1935) $811 \ldots \ldots \ldots \ldots \ldots \ldots 128$ Benjamin [matter of], (C.d'Et.) D. 1933.3.54 ........ I 59 Bertrand v. Rimbaud, (Confl.) Rec. 1874.643(644)...... I I5 Béziat v. Société Nord-Lumière, (Cass.) D. 1937.1.17(24),

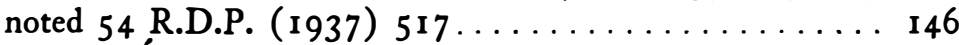
Blanco v. l'Etat, (Confl.) D. 1873.3.17(20), S.

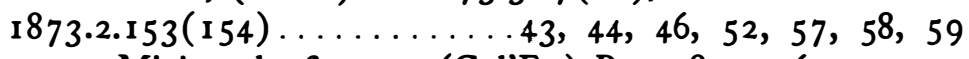

Blanco v. Ministre des finances, (C.d'Et.) Rec. 1874.416 ... 43 Bouhier v. Candelier, (Confl.) Rec. I881.918(919)...... I20 Bousquet v. Pougin, (Çonfl.) Rec. 1878.47 (48) ....... 115 Boyer et Jullian v. l'Etat, (Confl.) D. I93I.3.33, noted 48 R.D.P. (1931) 807.................. 54

Bruant (abbé) v. Maire de Breurey-les-Faverney, (C.d'Et.)

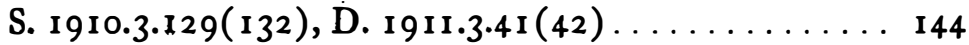

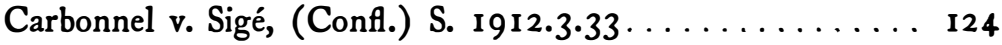
Catta v. Troquier, (Confl.) Rec. 1881.403 .......... I I4 Chailly-en-Bière, Commune de [matter of], (C.d'Et.) D. I 930.3.I, D.H. I 929.5 I 2, noted 47 R.D.P. (I 930) 773 . 60 Chambre syndicale, etc. [matter of], (C.d'Et.), Rec. I916.243 125 Chan Pek Chun v. Ministre de la Marine, (C.d'Et.) Rec.

1931.1125 ........................ 160 
Chauveau [matter of], (C.d'Et.) D. I934.3.I(2), noted 50 R.D.P. ( I 933) 246 .

Chemins de fer du Nord v. Vion et fils, (Confl.) D. 1916.3.57 (60), S. I917.3.I(2)

Chiron v. Sineau, (Cass.) D.H. I926.8I

Claire v. Jamot et Loison, (Confl.) Rec. I 929.389 . . . . . . . . 128

Clouet, Général [matter of], (C.d'Et.) Rec. I 844.493 . . . . I 36

Colonie de la Côte-d'Ivoire v. Société commerciale, etc., (Confl.)

D. $1921 \cdot 3 \cdot 1$.

Compagnie d'assurances "le Soleil" v. l'État, (Confl.) Rec. I 910.446 (449)

Compagnie d'assurances Rhin et Moselle v. Henry, (Confl.) D.

I 933.3.4 I

126

Compagnie générale de navigation, etc. v. Grandperrin, (Cass.)

D. I908.1.76.

Compagnie nouvelle d'éclairage, etc. v. Guiringaud, (Cass.) D.

I937.1.17, noted 54 R.D.P. (I937) $517 \ldots \ldots \ldots \ldots$ I 46 Compagnie nouvelle des Chalets, etc. [matter of], (C.d'Et.)

Rec. $1902.42 \ldots \ldots \ldots \ldots \ldots \ldots \ldots$ I59, I6 I

Corbon, Commune de, v. Vallet, (Cass.) D. 1877.1.9( (10) . . I I 39 Cotte [matter of], (C.d'Et.) Rec. I924.839 . . . . . . 159, I69 Coudert [matter of], (C.d'Et.) S. 1937.3.33(36), noted 54 R.D.P. (1 937) 370.

Coutareau v. Gillet, (Confl.) D. I913.3.130, S.

I 914.3 .5 I (52)

Cumont (de) \& Stofflet v. Engelhard, (C.d'Et., Confl.) D.

$$
\text { I } 872.3 .17(18)
$$

Dekeister v. Administration des postes, (C.d'Et.) S. I 862.2.1 39 .

Despujol [matter of], (C.d'Et.) S. I 930.3.4 I, noted 48 R.D.P.

(1931) 163

Dézétrée v. Maire de Meslay-le-Grenet, (Confl.) Rec.

I 883.939

Dionnet et Proton v. l'État, (Conff.) S. 1920.3.47(48) . . . I 28

Dubois [matter of], (C.d'Et.) Rec. I921.231 . . . . . . I 58

Duez v. Fournier, (App. Douai) D. 1936.2.5 I (53), noted 53

R.D.P. (1936) $685 \ldots \ldots \ldots \ldots \ldots \ldots \ldots \ldots$

Dufeuille v. Préfet de police, (Confl.) D. I890.3.65(66) . . . I 57

Dune v. Engelhard, (C.d'Et., Confl.) D. I 872.3.17( I8) . . . I 104 
Durand v. Société l'Energie électrique Rhône et Jura, (Confl.) D. $1934 \cdot 3 \cdot 57(60)$.

Engelhard [matter of], (Cass.) D. 1873.1.289 (29I) . . . . I04

Favre v. Mas, (App. Lyon) D. 1904.2.32 I (322) . I 42, I43, 148 Feutry v. Département de l'Oise, (Confl.) S. I908.3.97

(98) $\ldots \ldots \ldots \ldots \ldots \ldots \ldots \ldots \ldots \ldots 4,47,48,57$

Fonscolombe (de) v. Ville de Marseille, (Confl.) S. I 909.3.49

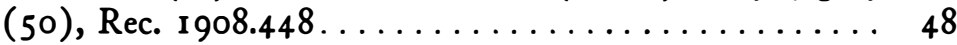

Fontenas v. B. . . , (Cass.) Gaz. Pal. 1923.2.319...... 127

Fournier v. Bonnefond, (App. Poitiers) D.H. 1936.502 (503),

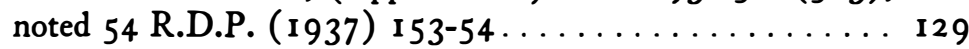

Frécon [matter of], (C.d'Et.) D.H. 1935.183, noted 52

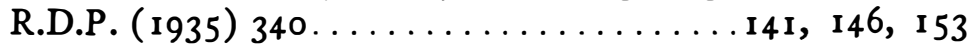
Frémy [matter of], (C.d'Et.) Rec. I 933.II $59 \ldots \ldots \ldots \ldots$ I 73

Gasté (de) v. Hospices, etc., (Conff.) D. I895.3.45 (46) . I60, I 73 Gérôme v. Gerbault, (Confl.) Rec. I 908.501 . . . . I 120, I24, I 28 Gilibert [matter of], (C.d'Et.) Rec. 1933.930 . . . . . . . I 68 Gillet v. Panier et l'Etat, (Confl.) S. I $909 \cdot 3.49$ (50) . . . . . 48 Ginière [matter of], (C.d'Ét.) Rec. I 904.88 . . . . . . . . I I 43

Girodet v. Morizot, (Confl.) D. I908.3.57, S. I908.3.8I, Rec. I908.597(603), noted 25 R.D.P. (I908)

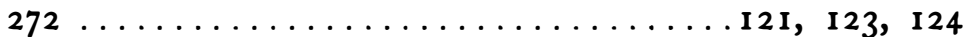

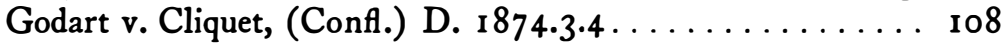

Gounouilhou v. de Tracy, (Confl.) Rec. I877.93 I (936), S.

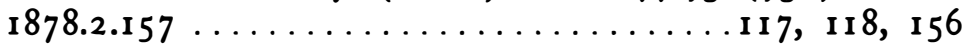

Grosson v. Souhet, (Confl.) Rec. I $902.644 \ldots \ldots \ldots \ldots$. . . I 19

Guillou v. Préfet de la Seine, (Cass.) S. I9I8-1919.1.193

(I94) $\ldots \ldots \ldots \ldots \ldots \ldots \ldots \ldots \ldots \ldots \ldots \ldots \ldots$ i, 83

Hostein \& Cie. [matter of], (C.d'Et.) D. I901.3.53 . . . I59, I6 I Huignard, consorts [matter of], (C.d'Et.) Rec. I 923.727 . . I 58

Immarigeon v. Perrin, (Confl.) Rec. 1922.185 . . . . . . 128

Joullié v. Assoc. syndic. du Canal, etc., (Confl.) S.

I $909.3 .49(50) \ldots \ldots \ldots \ldots \ldots \ldots \ldots \ldots \ldots \ldots$

Labadié v. Gaillardon, (Cass.) D. 1876.1.289(292) . 140, 143, I 73

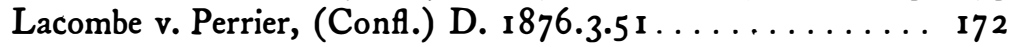


L'Action française v. Bonnefoy-Sibour, (Confl.) D. 1935.3.25 (28), noted 53 R.D.P. (1936) 296

$$
\text { 136, 141, 147, 155, 161, 169, 170, 172, 173, } 174
$$

Lajudie (de) v. Pomarède, (Cass.) D. I919.1.32 ....... 159

Lalande v. Peynaud, (Confl.) D. I899.3.93, Rec. I 897.758 (759), S. 1899.3.95 .............. II9, I 20, 124

Lamy v. Chemins de fer du Nord, (App. Paris) Gaz. Pal. I 930.1.68.4

Laumonnier-Carriol [matter of], (Confl.) S. 1878.2.93, D. 1878.3 .13

Laur v. Lemonnier, (Cass.) D. 1921.1.17 .......125, 126

Lebel v. Bault, (Confl.) D. I 892.3.1 10.......... I45, I 53 Lefèvre-Pontalis v. Chéronnet, (Cass.) S. I 864.1.248.97, 100, Io I Lemaire v. Préfet du Nord, (C.d.préf.) Gaz. Pal. 1937.1.396, noted 54 R.D.P. (1937) 381 .

Mabille v. Ville de Paris, (C.d'Et.) D. 1934.3.9(13) . .57, 58, 59 Marquié [matter of], (C.d'Et.) Rec. 1926.383 ........ 158 Martin v. Ville de Marseille, (Cass.) S. I918-1919.1.73(74). . 86 Mascaras v. Séné et Chiché, (Confl.) Rec. 1902.209, D.

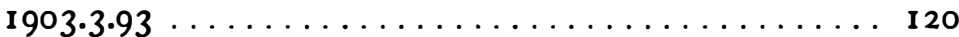

Maudière v. Maire et commune de Nouzon, (Confl.) Rec.

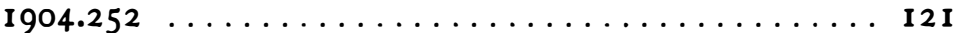

Mayer v. Kraencker, (Cass.) D.H. 1934.398 . . . . . . . 128 Mélinette [matter of], (Confl.) S. I 933.3.97, noted 5 I R.D.P. (1934) $140 \ldots \ldots \ldots \ldots \ldots \ldots \ldots 5,58,59,60,137$ Mende, Ville de, v. Roussel, (Cass.) D. I910.1.266(267) . 145, I 73 Meyère v. Rollin, (Cass.) D. I 872.I.385....... I03, I04, 108 Michau et Lafreney v. Boegner, préfet du Loiret, (Confl.) D. $1890.3 .65(67) \ldots \ldots \ldots \ldots \ldots \ldots \ldots \ldots \ldots \ldots \ldots \ldots$ Mignon (abbé) v. Godet, (Confl.) Rec. I910.442, S. 1910.3.129(132), D. I911.3.41(42).

Ministre des Travaux publics v. Mahieu, (C.d'Et.) D.H. 1932. I54, S. 1932.3.60................... I4 I Mohammed-ben-Belkassem [matter of], (Confl.) Rec. I89I. 542, D. 1892.3.125 ................... 123 Monpillié v. Gruet, Maire de Bordeaux, (Cass.) D. I92 I.I.4I (42), S. I918-1919.2.1.(2) . I I 3, I 24, I 25, I 26, I 59, I68, I72 
PAGE

Monségur, Commune de, v. Lalanne, (C.d'Et.) S. 1921.3.49. 56 Montlaur v. Balmigère, Maire de Tournissan, (Confl.) Rec. 1904.888(890), D. 1906.3.58(59) ........... 122, 172

Navarro et Mounier [matter of], (Confl.) D.H. 1926.55 ... 127

Neveux v. Administration des Postes et Télégraphes, (Confl.)

Rec. 1884.909 (910) . ................... 146

Pelletier v. de Ladmirault, (Confl.) S. 1874.2.28, D.

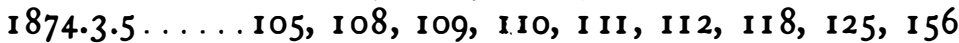

Pénicaud [matter of], (C.d'Et.) D.H. 1929.39 . . . . . . 159

Pérignon [matter of], (C.d'Et.) S. 1936.3.97 (98), noted 54

R.D.P. (1937) 146.................... 34

Petit [matter of], (Cass.) D. 1873.1.390............ 105

Piment (abbé) v. Guichard-Voillemond, Maire, (Confl.) Rec.

$1910.323(324)$, S. 1910.3 .129 (130), D.

I9II.3.4 I .................. 141, 144, I5I

Plet [matter of], (C.d'Et.) S. 1936.3.97(98), noted 54

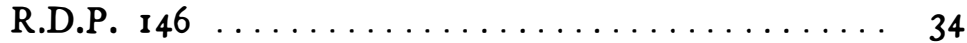

Pradines [matter of], (Confl.) Rec. $1875.764(765) \ldots \ldots$ II 6

Préfet de la Haute-Garonne v. Loumagne, (Confl.) Rec.

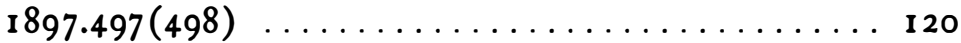

Raoulx v. Gallet, (Trib. sup.) D. I 897.2.225(226) ...... 82

Rèalmont (curé de) v. Maire de Rèalmont, (Confl.) S.

1935.3.97(98) ............ 144, I 48, I53, 173

Régie du Syndicat intercommunal, etc. v. Same, (Cass.) D.

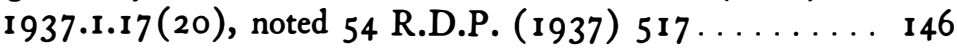

Regnault [matter of], (Cass.) S. 1 846.1.590.......... 100

Réquilé v. Grignoux-Vienne, (Confl.) Rec. 1879.803

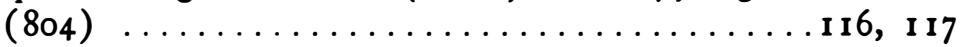

Rosay [matter of], (Confl.) D.H. 1933.336......... 27

Rubelles (de) v. Préfet de l'Allier, (Confl.) Rec. 1880.999

(1000) .......................114, 120

Saff roy v. Martin et Ligeron, (Confl.) Rec. 1894.628, D.

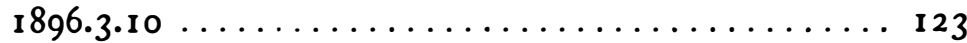

Sagot du Vauroux v. Fazuilhe, (Confl.) Rec. 1906.803 ..... 4 4

Saint-Martin v. Gaussorgues, (Cass.) Gaz. Pal. 1938.1.1 84, noted 55 R.D.P. (1938) 168. 
Schmitz v. Cabanel, (App. Paris) Gaz. Pal. I935.2.257 (258),

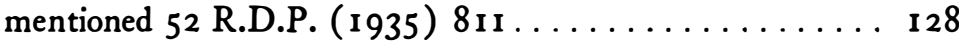

Septfonds v. Chemins de fer du Midi, (Confl.) S. I 923.3.49 (50), D. 1924.3.4 I . . . . . 81, 83, 86, 87, 88, 89, 93 Société des Eaux de Deauville [matter of], (C.d'Et.) D. I 934.3.I (3), noted 50 R.D.P. (I933) 246, 5 I R.D.P.

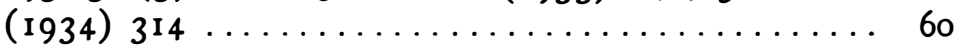
Société des Forces motrices d'Arrens v. Pahu, (Confl.) D. $1934 \cdot 3 \cdot 57(60)$

Société des granits, etc., v. Ville de Lille, (C.d'Et.) D. I916.3.35,

S. $1917 \cdot 3.15 \ldots \ldots \ldots \ldots \ldots \ldots \ldots$ 52, 54, 55, 56, 59 Société française d'industrie chimique [matter of], (C.d'Et.)

S. $1916.3 .1(2) \ldots \ldots \ldots \ldots \ldots \ldots \ldots \ldots \ldots \ldots$ Société immobilière de Saint-Just v. Préfet du Rhône, (Confl.)

D. $1903 \cdot 3 \cdot 4$ I (45), S. 1904.3.17(20)

1 39, I $51,163,164,165,167,168,169,171$ Société Laitière Maggi [matter of], (C.d'Et.) H.D.

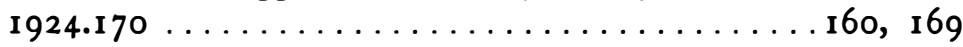
Soleillet v. Brière de Lisle, (Confl.) Rec. I 882.373(374) . . . I I 5 Spitz [matter of], (C.d'Et.) Rec. I920.1005(1006) . . . . . I 58 Sureau v. Rigaudie, (Confl.) Rec. I906.196, D.

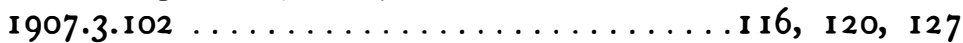

Suremain (de) [matter of], (C. d'Et.) Rec. 1907.345(348) . I 68 Syndicat des communes, etc. v. Société Cuvelier, (Cass.) D.

I937.1.I7(27), noted 54 R.D.P. (1937) $517 \ldots \ldots \ldots$ I46 Syndicat des communes, etc. v. Société Phelan-Ségur, (Cass.)

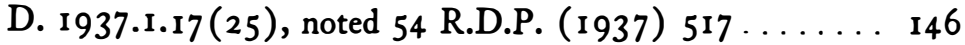
Syndicat des Marais mouillés v. Chauveau, (C.d'Et.) D.

I934.3.I (2) 60

Templier v. Commune de Sempigny, (Confl.) S. I928.3.129,

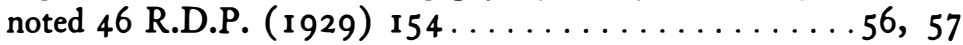
Terrier v. Département de Saône-et-Loire, (C.d'Et.) D.

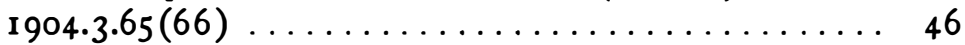
Thépaz v. Mirabel, (Confl.) Gaz. Pal. 1935.2.26 I . . . . . 128 Thérond v. Ville de Montpellier, (C.d'Et.) S. I9II.3.I 7 $50,51,52,54$

Thiney (abbé) v. Dompnier, (Confl.) Rec. I9I6.52 . . . . . I 44 Thomas v. Ruaux, (Confl.) Rec. I928.87I (872) . . . . . . 128 
Tubeuf v. Général du Guiny, (C.d'Et.) Rec. I 893.154(155). I16 Uhel v. Le Visage, (Confl.) Rec. I 900.5 I . . . . . . . . I I I Union Villeneuvoise de conserves, etc. [matter of], (Confl.) D.H. I $931.135 \ldots \ldots \ldots \ldots \ldots \ldots$ 145, I 53, I60, 173 Usannaz-Joris v. Lefebvre du Grosriez, préfet de la Savoie, (Confl.) D. I890.3.65(66) ................ 157

Valentin v. Haas, (Cass.) D. 1876.1.289(297) . . . . . . 108 Vaugeois-Héron v. Rieunier, (Cass.) D. I919.1.32 ...... 159 Verbanck v. Le Béguec, (Confl.) D. 1934.3.9(13), S. I 934.3.33, noted 50 R.D.P. (1933) 620, 5 I R.D.P.

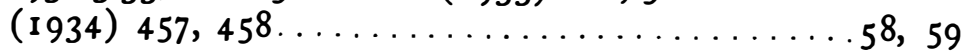
Viette v. Dalloz, (Confl.) Rec. 1877.1075(1077) ....... I1 Vimont v. Préfet de la Marne, (Confl.) Rec. I 884.58 I (582). . I 14 Vincent v. Fosse, (Confl.) Rec. I 890.1 83, D. I 891.3.3 I

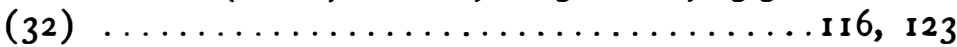




\section{Table of American Cases}

Bacon v. Rutland R: Co., (1914) 232 U. S. 134...... I79

Bakelite Corp., Ex parte, (1929) 279 U. S. 438 . . . . . . 63 Baltimore \& Ohio R. Co. v. United States, (1936) 298 U. S.

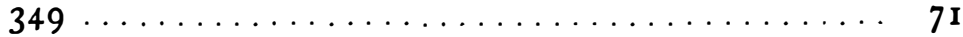

Barratt's Appeal, In re, (1899) I 4 App. D. C. $255 \ldots \ldots$. . I80

Borax Consolidated v. Los Angeles, (1935) 296 U. S. I o... . 7 I

Borgnis v. Falk Co., (I9II) I 47 Wis. $327 \ldots \ldots \ldots$ I 8 I, I 83

Borreson v. Department of Public Welfare, (1938) 368 Ill. 425 63,64

Chicago, Milwaukee \& St. Paul Ry. Co. v. Minnesota, ( 1890 ) I34 U. S. $418 \ldots \ldots \ldots \ldots \ldots \ldots \ldots \ldots \ldots$ 178, I79

Chin Yow v. United States, (1908) 208 U. S. 8 . . . . . I 182 Crowell v. Benson, (1932) 285 U. S. $22 \ldots 7$ I, I 33, 181, 1 83

Edward Hines Yellow Pine Trustees v. United States, (1923) 263 U. S. $143 \ldots \ldots \ldots \ldots \ldots \ldots \ldots \ldots \ldots$

Elliott v. El Paso Electric Co., (C. C. A. 5th, 1937) 88 F. (2d) 505

Ex parte-see under name of party.

Federal Radio Commission v. General Electric Co., (1930)

28 I U. S. $464 \ldots \ldots \ldots \ldots 33,63,64,66,179,180,187$

Federal Radio Commission v. Nelson Bros. Bond \& Mortgage

Co., (I933) 289 U. S. $266 \ldots \ldots \ldots \ldots \ldots$. . . . . 63, 64

Federal Trade Commission v. Klesner, (1 929) 280 U. S. I9. 70 Foss v. City of Lansing, (1927) 237 Mich. 633 ...... 58

Haley v. City of Boston, (I906) I9 I Mass. 29 I . . . . . 58 Hartwell Mills v. Rose, (C. C. A. 5th, 1932) 6I F. (2d) 441 . 132 Hayburn's Case, (1 792) 2 Dall. (2 U. S.) 409. . . .663, 66, 68 Hodges v. Public Service Commission, (I93I) i ro W. Va.

$649 \ldots \ldots \ldots \ldots \ldots \ldots \ldots \ldots \ldots \ldots \ldots \ldots \ldots \ldots \ldots \ldots$

Interstate Commerce Commission v. Northern Pacific Ry. Co.,

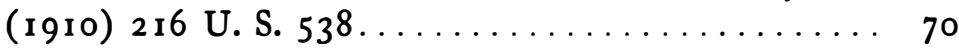


Keller v. Potomac Electric Power Co., ( I 923) 26 I U. S. 428. . 63 Liberty Warehouse Co. v. Grannis, (I927) 273 U. S. 70. . . 9I Moore (George) Ice Cream Co. v. Rose, (1933) 289 U. S. 373

Murray's Lessee v. Hoboken Land \& Improvement Co., (1 855) I 8 How. (59 U. S.) $272 \ldots \ldots \ldots \ldots \ldots \ldots \ldots$ I79, I 87 Muskrat v. United States, ( I 9 I I) 2 I 9 U. S. $346 \ldots \ldots \ldots 66$, 9 I Myers v. Bethlehem Shipbuilding Corp., (1938) 303 U. S. 41 . . 68

Nectow v. City of Cambridge, (1928) 277 U. S. 183 . . . . 33 Ng Fung Ho v. White, (I922) 259 U. S. $276 \ldots \ldots \ldots \ldots$ I . . . 82 Norwalk Street Railway Company's Appeal, (1897) 69 Conn. 576 186

O’Donoghue v. United States, ( I 933) 289 U. S. $516 \ldots$. .64, I 85 Ohio Valley Water Co. v. Ben Avon Borough, (1920) 253 U. S. $287 \ldots \ldots \ldots \ldots \ldots \ldots$ I , I 79, I 82

Oklahoma Natural Gas Co. v. Russell, (1923) 26 I U.S. $290 .$. 37 Old Colony Trust Co. v. Commissioner of Internal Revenue, (1929) 279 U. S. 716.

Pacific States Box \& Basket Co. v. White, (1935) 296 U. S.

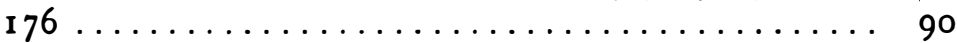

Palermo Land \& Water Co. v. Railroad Commission of California, (D. C. Cal. 1915) 227 F. 708. I 81

Panama Refining Co. v. Ryan, (1935) 293 U.S. 388. 90

People ex rel. Central Park, N. \& E. River R. Co. v. Willcox, ( I 909) I 94 N. Y. 383. I 82

People ex rel. Steward v. Board of Railroad Commissioners, (1899) I60 N. Y. $202 \ldots \ldots \ldots \ldots \ldots \ldots \ldots \ldots$ I 86

Piedmont \& Northern Ry. Co. v. United States, (I 930) 280

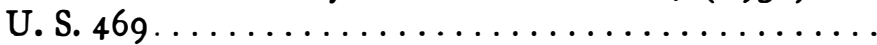

Postum Cereal Co. v. California Fig Nut Co., (1927) 272 U. S. $693 \ldots \ldots \ldots \ldots \ldots \ldots \ldots \ldots \ldots \ldots \ldots \ldots \ldots$, 186

Prentis v. Atlantic Coast Line Co., (1908) 2 I I U. S. 2 I 0 $\ldots \ldots \ldots \ldots \ldots \ldots \ldots \ldots \ldots \ldots 33,37,68$, I 79, I 8 1, I 86

Proctor \& Gamble Co. v. United States, (I912) 225 U. S.

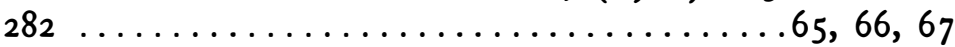

Public Service Commission of Puerto Rico v. Havemeyer, ( 1936 ) 296 U.S. 506 
Rochester Telephone Corp. v. United States, (1939) 307 U. S. I $25 \ldots \ldots \ldots \ldots \ldots \ldots \ldots \ldots \ldots \ldots \ldots \ldots, 66,67,69,183$

St. Joseph Stock Yards Co. v. United States, (1936) 298 U. S. 38

Schechter (A. L. A.) Poultry Corp. v. United States, ( 1935)

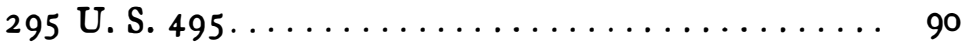
Shields v. Utah Idaho Central R. Co., (1938) 305 U. S. I77 . . 7 I Texas \& Pacific Ry. Co. v. Abilene Cotton Oil Co., (I 907) 204

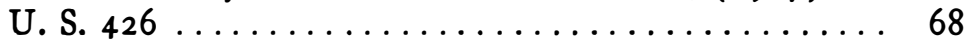

United States v. Ju Toy, (I 905$)$ I 98 U. S. $253 \ldots \ldots \ldots 70$, I 82 United States v. Los Angeles \& S. L. R. Co., ( 1927 ) 273 U. S. $299 \ldots \ldots \ldots \ldots \ldots \ldots \ldots \ldots \ldots \ldots \ldots$, 66, I 79

United States v. Sherman, (I 878 ) 98 U. S. $565 \ldots \ldots \ldots \ldots$ I 32 United States Navigation Co. v. Cunard Steamship Co., (1932) 284 U. S. $474 \ldots \ldots \ldots \ldots \ldots \ldots \ldots \ldots \ldots$, I 8 I Upshur County v. Rich, (I890) I 35 U. S. $467 \ldots \ldots \ldots \ldots$ I . . 86 Village of Saratoga Springs v. Saratoga Gas, Electric Light, \& Power Co., (1908) ig I N. Y. I $23 \ldots \ldots \ldots \ldots \ldots \ldots$ I 82

White v. Hopkins, (C. C. A. 5th, I93 I) 5 I F. (2d) I $59 \ldots$... I 3 I Willing v. Chicago Auditorium Assn., (I928) 277 U. S. 274 . 9I Wood Towing Corp. v. Parker, (C. C. A. 4th, 1935) 76 F. (2d) 770 7 I 


\title{
PART I
}

\section{THE DOCTRINE}

\author{
OF THE
}

\section{SEPARATION OF POWERS}

\begin{abstract}
"The doctrine of the three powers, when carefully analyzed, perhaps shows the readiness of the human mind to take words for things, formulas for arguments, and to accept a certain set of ideas without ever reexamining the intelligible definition which it has taken for an axiom." Mirabeau, in the Constituent Assembly of $\left.{ }_{1789}\left(J_{u l y}{ }_{16}\right)\right)^{1}$
\end{abstract}

${ }^{1}$ Quoted by Ducrocq, Cours de droit administratif, 7th ed. (1897), Vol. 1, p. 39; Moreau, Le règlement administratif (1902), p. I 79, note I. The translation of the passage in White, James, Speeches of M. de Mirabeau, the Elder, Pronounced in the National Assembly of France (London, I 792), pp. 133-34, is slightly different. 


\title{
Development of the Doctrine of the Separation of Powers in France
}

\section{A. THE UOCTRINE OF THE SEPARATION OF POWERS}

\author{
AS CONCEIVED BY MONTESQUIEU
}

$\mathrm{N}$ order to appraise the influence of the doctrine of the separation of powers ${ }^{1}$ upon the formulation of certain con1 cepts of administrative law, it is indispensable to review its historical evolution. Only complete awareness of the historic political environment attending its reception into a given governmental scheme can insure the requisite definiteness of meaning. Abstract theory ever since Aristotle, to be sure, has had nodifficulty in distinguishing various functions of the state, i. e., functions in the sense of differing forms of state activity

${ }^{1}$ Out of the great mass of general and topical treatments of the separation of powers doctrine, the following deserve especial mention in connection with the subject at hand:

For an excellent general survey of the doctrine as conceived at various times by well-known writers of the English- and non-English-speaking world, see Fairlie, "The Separation of Powers," 21 Mich. L. Rev. (1923) 393. See also Ghose, Comparative Administrative Law (1919), p. 75 ff.

For an equally noteworthy treatment of the subject, primarily devoted to its significance in the United States, see Sharp, "The Classical American Doctrine of 'The Separation of Powers," " 2 U.Chi. L. Rev. (1935) 385 . See also The Federalist, Nos. 47, 48 and 51; Erlick, La séparation des pouvoirs et la Convention Fédérale de 1787 (1926).

Of primary importance for France are the pertinent chapters in Duguit, Traité du droit constitutionnel [2d ed, 1921-1925], and Esmein, Eléments du droit constitutionnel frangais et comparé [7th ed., 1921]. Jacquelin, Les principes dominants du contentieux administratif (1899) and Artur, De la séparation des pouvoirs et de la séparation des fonctions de juger et d'administrer (1905) [first published in 13 R. D. P. (1900) 214, 470, 14 ibid. (1900) 34, $236,436,17$ ibid. ( 1902 ) 78, 234, 439, 20 ibid. (1903) 41 5], are especially concerned with the interpretation of the doctrine in the light of French administrative law.

Topical expositions will be found in the various treatises on administrative law referred to in the text and notes. See Berthélemy, Traité élémentairs de droit administratif, I $3^{\text {th }}$ ed. (1933), p. $9 \mathrm{ff}$. 
designed for the accomplishment of a variety of state purposes. But the doctrine of separate powers in the modern sense of a working mechanism is not an abstract code of law. Nor does this doctrine of the separation of powers spring from a theory of higher law comparable to the familiar concept of natural law. In every instance where its offices are invoked, it is made to serve the practical governmental exigencies of the moment. In every such instance its invocation is the immediate consequence of given political situations for which some remedy or improvement is sought. ${ }^{2}$ And although the political theorists who, up to the middle of the eighteenth century, had concerned themselves with problems of governmental powers ${ }^{3}$ may not have expressly admitted it, they were undoubtedly and invariably influenced by the prevailing ideas and conditions of their times.

When Montesquieu wrote his book, L'Esprit des lois, France was dominated by the absolutistic regime which nurtured the elements of the Revolution. Montesquieu's extended travels ultimately had brought him to England, and during his sojourn there he found inspiration in the institutions of that country. ${ }^{4}$ In Book XI of his well-known work, in the chapter (VI) headed "Of the Constitution of England," he says that liberty depends upon and can exist only if a particular principle of government is applied, i. e., if the powers of government are exercised by separate agencies. The principle so expounded was novel in its emphasis upon the distribution of governmental powers, and in this form it was destined to at-

${ }^{2}$ See Fairlie article, 2 I Mich. L. Rev. 393. Cf., e. g., Jellinek, Allgemeine Staatslehre, 3d ed. (1929), p. 595 ff.; Duguit, Traité, Vol. 2, pp. 514 ff, 534 ff. Vol. 3, p. 29 ff.; Duguit, Etudes de droit public (1903), Vol. 2, p. 281 ff.; Kelsen, Hauptprobleme der Staatsrechtslehre, 2d ed. (1923), p. 5 I I ff.; Moreau, Le règlement administratif (1902), p. 252; Mayer, Deutsches Verwaltungsrecht, 2d ed. (1914), Vol. 1, p. 57, note 2; Stein, Grenzen und Beziehungen zwischen Justiz und Verwaltung ( 191212$)$, p. I ff.

${ }^{8}$ See Fairlie article, 2 I Mich. L. Rev. 393.

'See Montesquieu, The Spirit of Laws, Nugent translation (1823 reprint of I 766 ed.), p. v ff. 
tract the minds of the contemporary statesmen of the two liberty-seeking peoples of the United States and of France. The principle, as variously interpreted at the time, found its way into the respective constitutions of these countries. ${ }^{5}$ Since then, uninquiring tributes and references to Montesquieu have been without number and are still frequent today. Instead of indulging in more tributes, it is proposed first to reexamine ${ }^{6}$ objectively Montesquieu's ideas, and then to ascertain the respective evils sought to be remedied by applying his precept. This procedure is indispensable to the correct appraisal of the interpretations of the doctrine of the separation of powers and of its consequent effects upon the relation between administration and judiciary.

In the examination of Montesquieu's theory, three observations are of particular significance. First, it is not open to serious doubt that Montesquieu, in keeping with many writers, including John Locke, ${ }^{7}$ recognized only two primary powers of the state, the legislative and the executive. ${ }^{8} \mathrm{An}$ analysis by d'Alembert introducing Montesquieu's book confirms the view that then prevailing thought envisaged but these two governmental powers. Thus, d'Alembert says, "There are in the constitution of every state two sorts of powers, the legislative and the executive; and this last has

${ }^{5}$ See the French constitutions of September 3, 1 791; 5th Fructidor, year III (Aug. 22, 1 795); November 4, 1848.

- Without claim to originality or novel treatment. For a drastic illustration of the dangers lurking in hastily formulated or preconceived notions, see Professor Georg Jellinek's critique, "Eine neue Theorie über die Lehre Montesquieu's von den Staatsgewalten," 30 Zeitschrift für das Privat und Öffentliche Recht der Gegenwart (1903) I ff.; and Professor Rehm's reply, ibid. 4 7 ff.

${ }^{7}$ Locke, distinguishing three powers corresponding to the legislative, executive, and federative tasks of the commonwealth, concludes that "Though ... the executive and federative power of every community be really distinct in themselves, yet they are hardly to be separated, and placed at the same time, in the hands of distinct persons. ..."Locke, An Essay Concerning Civil Government (1773), p. 78; also in Two Treatises of Government (1698), p. 280.

${ }^{8}$ Montesquieu, L'Esprit des lois, Book XI, chap. VI [Pourrat ed. (1834), Vol. I, p. 293 ]. For an English translation, see that of Thomas Nugent made in 1766 and reprinted in 1823 . 
two objects, internal affairs and foreign relations." ${ }^{9}$ This passage is particularly helpful because Montesquieu's use of terms is conveniently loose and has lent itself to differing interpretations. In the first paragraph of chapter VI Montesquieu himself opens with the well-known statement in which he distinguishes "three kinds of powers; ${ }^{10}$ the legislative power, the power to regulate the affairs depending upon the law of nations, ${ }^{11}$ and the power to regulate those depending upon the civil law."12 This might seem to indicate that the author conceived of two powers, the legislative and the executive, and of three functions, one coinciding with the legislative and the other two falling under the executive power. Nevertheless, the succeeding paragraph again leaves one at sea. There is no difficulty about the first power, but the second is described as that concerned with the external matters of "peace and war, the sending and receiving of ambassadors, security, prevention of invasions." The third power extends to the "punishing of - crimes, and the adjudication of the differences of individuals," and is called "the power to adjudicate." What has become of the management of internal affairs? Is administration embraced in the second or third? Apparently what seemed important to Montesquieu was that two powers should be recognized, one of which, the executive, envisaged two distinct objects. There is very little indication, if any, of an intent to classify the "power to adjudicate" as an independent coordinate power. On the contrary, in another place in the text ${ }^{13}$ "the three powers" forming "the fundamental structure of

'Pourrat ed., Vol. I, p. 9 (Nugent translation, p. xx).

${ }^{10}$ In the first part of the sentence the word "pouvoir" is used, while "puissance législative" and "puissance exécutrix" appear after the colon.

${ }^{11}$ Both of these powers are termed "puissances exécutrices," i. e., powers "for the execution" of the law of nations on one hand, and of the civil law on the other hand.

${ }^{2}$ Montesquieu, Book XI, chap. VI (Pourrat ed., Vol. I, p. 293).

Ibid., p. 307 . 
the government of which we have spoken" expressly refer to the two houses of the legislature and to the executive. And again, another passage ${ }^{14}$ states that "of the three powers [puissances] which we have mentioned, the judicial power is somehow nonexistent [ mulle]. There are in fact but two."15

Secondly, what appears to be of the foremost interest to Montesquieu is the distribution among separate agencies of the functions to be exercised. This emphasis upon the differentiation of agencies, which is generally recognized as original with Montesquieu, is expressed in clear terms at the beginning of chapter VI. It is further accentuated in the closing chapter of the book, ${ }^{16}$ where it is said that the degree of liberty possible under any government is determinable according to the distribution of the governmental "powers." 17

The third proposition to which attention should here be directed is the placing in Montesquieu's theory of the judicial "power." The opinion has already been expressed that judicial power was considered but one phase or branch of the executive, and a separate "power" only in the limited sense of a function to be exercised by distinct officials or agencies. ${ }^{18}$ It

1s Ibid., p. 300.

${ }^{15}$ The question whether two or three powers had been envisaged by Montesquieu was the subject of a great deal of discussion in the constitutional assembly of 1789 . Most prevalent seems to have been the viewpoint defended by Ducrocq, Cours de droit administratif, 7th ed. (1897), Vol. 1, p. $37 \mathrm{ff}_{\text {.y. }}$ i. e., that there are but two powers and that the judicial "power" was part of the executive, because "all justice emanates from the Crown."

Cf. Aucoc, Conférences sur l'administration et le droit administratif, $3 \mathrm{~d}$ ed. ( 1885 ), Vol. I, p. 55 ff.; Duguit, Traité, Vol. 2, p. 538 ff.; Berthélemy, Traité, p. I1. Cf. also the modern doctrines as to the basic legislative and administrative functions. Mayer, Vol. 1, p. 57; Jellinek, Allgemeine Staatslehre, p. 558; Kelsen, p. 511 . See also the American authorities cited incidentally in Beutel, "Valuation as a Requirement of Due Process of Law in Rate Cases," 43 Harv. L. Rev. (1930) 1249 at 1257 , note 22.

${ }^{10}$ Montesquieu, Book XI, chap XX (Pourrat ed., Vol. I, p. 347 ).

${ }^{17}$ " $\mathrm{Je}$ voudrois rechercher, dans tous les gouvernements modérés que nous connoissons, quelle est la distribution des trois pouvoirs, et calculer par là les degrés de liberté dont chacun d'eux peut jouir. . . ."

${ }^{18} \mathrm{Cf}$. Appleton, Traité élémentaire du contentieux administratif (1927), p. 18 . 
must also be noted that Montesquieu advocates that the power and influence of the judicial authorities be minimized, ${ }^{19}$ and that they be not treated as a coordinate branch of the govern-

- ment but as entirely subordinate to the legislature and the executive. ${ }^{20}$ It is important to bear in mind Montesquieu's conception of the judicial branch of the government, for it had its roots in the very conditions of the times. It will be shown that this conception was well adapted to the objectives of the ensuing revolution, whose leaders it must have prompted in seizing upon Montesquieu's ideas for guidance.

B. THE HISTORICAL BACKGROUND OF THE DOCTRINE OF THE SEPARATION OF POWERS IN FRENCH LAW

It is clear that in France, as in this country, the separation of powers had a definite function to perform when it was made an integral part of a new regime. The separation of powers was intended to make secure the achievements of a recent revolution. Consequently the conditions preceding the revolution are elementary factors in determining the true meaning of the doctrine and they must be recalled if the latter is to be fully understood.

\section{The King and the Parlements}

A monarchy of the absolute type, like that of prerevolutionary France, combines in one person, the monarch, all powers requisite for carrying on the functions of the state. However, the complexity of the affairs of the state necessitates a division of labor. Thus, in the middle of the eighteenth century governmental power in France was vested in the king

${ }^{19}$ Montesquieu, Book XI, chap. VI (Pourrat ed., Vol. I, p. 296).

${ }^{20}$ Ibid., pp. 296, 300-306. Referring to impeachment of public officers, Montesquieu suggests (p. 306) that the lower house of the legislature "can be but the accuser; but before whom shall it make its accusation? Shall it stoop before the ordinary courts which are its inferiors?" 
and exercised by him nominally through his council and his intendants with the cooperation of the parlements. Actually, the latter had entered into competition with the Crown. ${ }^{21}$ The king, from whom all power was held to emanate, governed through the Conseil $d u$ roi $^{22}$ (embracing four principal and distinct conseils) and intendants, ${ }^{23}$ to whom power was delegated primarily for the administration of the royal finances and taxation. On the other hand, a considerable amount of governmental authority, coupled with political power, rested with the parlements. Indeed, we find that in addition to their judicial powers, the parlements claimed and exercised important legislative and administrative powers ${ }^{24}$ which came into direct conflict with governmental action originating in the Crown. This conflict derived from the very fact that whatever powers the parlements possessed were delegated ones.

At the outset the king dispensed justice personally with the aid of his council, the same council that advised him in matters of state. It was this council from which the Parlement de Paris first detached itself as an independent body, while similar provincial parlements were later formed throughout the land. ${ }^{25}$ In theory these courts continued to owe their authority to the Crown, which might revoke and exercise it personally at will. However, in time these judicial bodies began to assert their independence. And even though they came to use their

${ }^{21}$ Out of the old curia regis had developed first the Parlement de Paris. Provincial Parlements were then added, all of which in turn became the highest courts of justice in the land, although they continued to participate in the exercise of legislative and administrative functions. Esmein, Cours élémentaire d'histoire du droit fraņ̧ais, 11th ed. (1912), p. 409 ff.; Laferrière, Traité de la juridiction administrative et des recours contentieux, $2 \mathrm{~d}$ ed. (1896), Vol. 1, p. 139 ff.; Hauriou, Précis de droit administratif, 1 oth ed. (1921), p. 5 ff., I 2th ed. (1933), p. 4 ff.; Brissaud, A History of French Public Law (translated by James W. Garner, The Continental Legal History Series, 1915 ), p. $378 \mathrm{ff}$.

\footnotetext{
${ }^{29}$ Esmein, Cours élémentaire, p. 528 ; Brissaud, p. 378.

Esmein, p. 658 ; Brissaud, p. 406.

${ }^{2}$ Esmein, p. 582 ff.; Brissaud, p. 432 ff.

${ }^{20}$ Esmein, p. 434 ff.; Brissaud, p. $432 \mathrm{ff}$.
} 
growing influence to obstruct the central administration, it had now become impossible to divest them of their powers. The judicial offices-parlements and inferior tribunals alike -in the course of time had become venal and hereditary. With the constantly increasing needs of the royal treasury, the sale of these offices had become a substantial source of revenue, to the obvious detriment of royal sovereignty. In turn, the judicial officers found themselves compelled to "sell justice" in order to reimburse themselves and to get a return on their investment. ${ }^{26}$ When, under Louis XIV, reforms were proposed, it was found that the evil was too firmly rooted to be eradicated. A class of public officials had come into existence whose tenure would no longer yield to ex parte revocation. Crown and judiciary alike depended on the established system for income.

\section{Judicial Interference with the Executive}

The various forms of interference by the judiciary to which the administrative was henceforth exposed affected both the legislative and the administrative prerogatives of the king. ${ }^{27}$ In the first place, under their general jurisdiction the parlements could take cognizance of matters of political consequence. Thus they could, and frequently did, prosecute high public officials for crimes imputed to them with or without factual foundations. Their most powerful weapon, however, consisted in the requirement that all acts resulting from the exercise of legislative power by the Crown be registered in parlement, i. e., "verified" after deliberations. ${ }^{28}$ Registration could be refused in whole or in part, with power to make modifications, and by way of "remonstrance" the reasons for the action taken were transmitted to the king. This power of

${ }^{20}$ Esmein, p. 45 I ff.; Brissaud, p. 458.

${ }^{27}$ Esmein, p. $582 \mathrm{ff}$.; Brissaud, p. $445 \mathrm{ff}$. As to the legislative powers of the Etats généraux, cf. Esmein, p. $539 \mathrm{ff}$.

${ }^{\circledast}$ Esmein, p. 585 ; Brissaud, p. 445 ff. 
"registration" belonged equally to the Parlement de Paris, to the twelve provincial parlements, ${ }^{29}$ and to the other sovereign courts.

Against all these sources of friction the Crown maintained -the position that all governmental power, though delegated to some extent, remained ultimately in the king, and this principle was not entirely devoid of sanctions. On the theory of justice retenue, ${ }^{30}$ the king could withdraw from the courts (by way of évocations) controversies over which they had acquired jurisdiction, in order to have them disposed of in his council. ${ }^{31}$ Where legislative powers were involved, the king again relied on the theory that all powers of the parlements rested solely upon concession from him. Hence he might send a written command to the parlement demanding registration of his royal ordinance ${ }^{32}$ or, where this failed to enforce obedience, he could proceed by what was known as lit de justice, ${ }^{33}$ i. e., he could appear personally in the parlement and direct the immediate inscription of the ordinance in his presence. The parlements in turn had a further effective means by which they could obstruct the Crown if their hands had been forced by a lit de justice. Acting as courts, or their individual members as judges, they might retaliate by refusing to take notice of or to enforce ordinances so registered against their will.

C. THE SIGNIFICANCE OF THE DOCTRINE OF THE SEPARATION OF POWERS IN POST-REVOLUTIONARY FRENCH LAW

\section{The Basic Principle}

The acute lack of synchronization of the executive and judicial machinery under the ancien régime in France had

${ }^{\infty}$ Esmein, p. 436.

${ }^{80}$ Esmein, p. 484 ff.; Brissaud, p. $428 \mathrm{ff}$.

"Esmein, P. 485; Brissaud, p. 430.

"Letwe de jussion-Esmein, P. 591 ; Brissaud, p. 449.

Esmein, Pp. 591-592; Brissaud, p. 449. 
caused serious frictions which could not fail to have disastrous consequences. After the revolution had swept over France, the leaders of the new regime were greatly concerned with devising means to prevent the recurrence of similar conditions. To this end they incorporated Montesquieu's theory of free government ${ }^{34}$ in the legislation of 1789 and in the subsequent constitutions, hoping to accomplish two things: ( 1 ) to secure a new form of monarchical government in which popular sovereignty was reflected, and political liberty established, through a legislative body which was independent of the executive; (2) to insure a system under which the administration could fulfill unhampered the tasks which the revolution had entrusted to it. These objectives were to be attained by the separation of the legislative and executive powers, and by a differentiation of the administrative and judicial agencies.

Thus, the doctrine of the separation of powers in France carries a two-fold meaning. It denotes, frst the divorce of the two recognized powers of the legislative and executive, commonly referred to as séparation des pouvoirs, and, second, the distribution of the judicial and administrative functions among separate agencies. This latter aspect of the doctrine is usually termed la séparation des autorités administrative et judiciaire or, more briefly, la séparation des autorités. ${ }^{35}$ It is this second meaning which will be the exclusive subject of the following analysis, and in order to preserve the essential distinction it will be designated as "differentiation of agencies."36 It was felt that the government could not effectively

${ }^{34}$ Many of the prominent members of the Assemblée Constituante of 1789 were familiar with Montesquieu's writings. They extolled, discussed, but also criticized extensively in the constitutional debates his theory of the separation of powers. See Ducrocq, Vol. I, p. 37 ff.; Aucoc, Vol. I, p. 47 ff.; Jacquelin, Les principes, p. I 4 ; Duguit, Traité, Vol. 2, p. $514 \mathrm{ff}$.

${ }^{85}$ Berthélemy, Traité pp. 9 ff., 20 ff.

${ }^{30}$ The terminology employed in France is generally consistent in observing the distinction. Nevertheless there are occasional instances in which séparation des pouvoirs is used by courts though the intended reference is to the differen- 
pursue its new policies if the courts were permitted to continue to exercise any direct or indirect influence or control ... over administration. Montesquieu's theory, according to which the judicial "power," though given to a separate body of officials, was to be a subordinate branch of government without political power, lent itself admirably to the accomplishment of this purpose and to the dispelling of existing fears that the political and administrative unity of the centralized government might be disturbed by a judiciary presumed to be always reactionary. From the differentiation of the administrative and judicial agencies in this sense, high hopes were held for the efficacy of the new regime. Through it evils flowing from class distinctions, differences in custom, and even differences in nationality might be overcome. ${ }^{37}$

The principle of the differentiation of agencies found expression in a series of constitutional and statutory enactments, all of which provide in substance that the judiciary shall not in any manner whatever interfere with administrative action. ${ }^{38}$

tiation of agencies, and in translating quotations it will be necessary here and there to adopt the less accurate term.

${ }^{87}$ Laferrière, Vol. I, pp. 1 82-83; Jacquelin, Les principes, p. 22 ff.; Esmein, Précis élémentaire de l'histoire du droit français de 1789 à 1814 (1908); Esmein, Eléments de droit constitutionnel, Vol. 1, p. 531 ff.; Jèze, Les principes généraux du droit administratif, 3d ed. (1925), p. 265 ; Duguit, "The French Idministrative Courts," 29 Pol. Sci. Q. (1914) 385 (translation).

${ }^{38}$ Sec. III, art. 7, Law of December 22, 1789 : "The administrations of the departments and districts shall not be hampered in the exercise of their functions by any acts of the judicial power." Tit. II, art. 13, Law of 16-24 August, I 790: "The judicial functions are distinct and shall forever remain separated from the administrative functions. The judges may not, under penalty of forfeiture, interfere in any manner whatsoever with the operations of the administrative agencies; nor shall they summon before them administrative functionaries on account of their official functions." Tit. III, chap. V, art. 3, of the Constitution of Sept. 3, 1791: "The courts shall . . . not assume any administrative functions or summon before them administrative officers on account of functions exercised by them." Law of the 16 th Fructidor, year III (Sept. 2, I 795): "The courts are again prohibited from taking cognizance of all acts of the administration of whatever nature." See Laferrière, Vol. 1, pp. 1 81-83; Duguit, Traité, Vol. 3, pp. 31-32; Appleton, p. 20; Duguit et Monnier, Les Constitutions et les principales lois politiques de la France depuis 1789 , 4th ed. (1925). 
Penalties and forfeitures were provided for transgressions by courts and judges, ${ }^{39}$ while administrative officials were equally enjoined not to encroach upon the judicial domain. ${ }^{40}$ The principle thus established ultimately led to the administrative system now in force, which is characterized by its alleged freedom from interference and control by the judicial branch of government, and which has developed its own independent courts.

\section{Evolution of the Administrative System}

At the outset, before administrative courts had come into existence, the prohibition against interference by the judicial --courts resulted in making the administrative hierarchy judge in its own cause, in the fullest sense of that expression. ${ }^{41}$ The individual citizen depended entirely upon the several administrative agencies for the hearing of his complaints. For obvious reasons, at this stage of development protection of the individual was not the main objective. Concern with administrative self-protection stood in the foreground, and only gradually did considerations of private interest gain momentum as a force contributing to the evolution of modern administrative law concepts. ${ }^{42}$

- Up to I 849 the Conseil d'État, which was to become so prominently identified with the dispensation of administrative justice, was but an advisory council ${ }^{43}$ of the chief execu-

${ }^{30}$ Tit. II, art. 1 3, Law of 16-24 August, I 790, supra.

${ }^{10}$ Tit. III, chap. IV, sec. II, art. 3, Constitution of Sept. 3, I 79I: "The administrative functionaries . . . may not encroach upon the domain of the judicial authorities." Art. 189 , Constitution of the 5 th Fructidor, year III (Aug. 22, I 795): "The administrative authorities . . . shall not interfere with matters of judicial competence."

"Laferrière, Vol. 1, pp. 13-14.

${ }^{4}$ Duguit, Les transformations du droit public (1921); Hauriou, Précis, I oth ed., p. 874, 12 th ed., p. 344 .

${ }^{4}$ Although in 1806 the first Commission du contentieux was formed within the council for the adjudication of administrative controversies. See Appendix, pp. I 6-1 8, for a detailed description of the Conseil d'ttat and other administrative courts. 
tive. The latter, on the theory of justice retenue, retained ... power finally to decide all administrative controversies. In I 849 the principle of justice déléguée was adopted with the creation of an administrative court (section du contentieux) within the Conseil d'Etat with final and exclusive jurisdiction in administrative matters. Still later, in 1852 , due to changing political fortunes, the "court" once more lost its independence, justice retenue was restored, and administrative justice once more had its nominal source in the chief executive.

Nevertheless, the Conseil by way of precedent gradually expanded its jurisdiction. By decree of November 2, 1864, recourse to the Conseil d'État against acts of administrative agents who had exceeded their powers was deliberately encouraged, with the enactment of a statute reducing to an almost negligible sum the costs connected with filing protests. While political reasons had first begotten the postulate of differentiation of administrative and judicial agencies, the necessity for a central judicial control within the administrative now made itself felt. This need was expressed by Leon Aucoc, an outstanding writer and member of the Conseil, in these words: "The government, upon which falls the responsibility for the mistakes of its agents, has a great interest that all complaints which they may cause be brought before it; for the most minute grievances, when increasing in number, may lead to serious discontent. There is then a sort of safety valve which must ever be open." ${ }^{\text {44 }}$ It should be observed that the question whether this judicial control should be given to the ordinary courts was at one time a subject of dispute. ${ }^{45} \mathrm{How}-$ ever, the traditional doctrine of the differentiation of agencies, aided by the weighty argument of the special fitness of administratively trained officials, caused the pendulum to swing

\footnotetext{
* Aucoc, ist ed. (1869), Vol. 1, p. 394, quoted by Laferrière, Vol. I, p. 258.

${ }^{4}$ Jacquelin, Les principes, p. 1393 Duguit, article, 29 Pol. Sci. Q. 385 at 390-391.
} 
far toward administrative courts for the adjudication of controversies involving administrative acts. ${ }^{46}$

With the enactment of the law of May 24, I 872 , the Conseil d'Etat ${ }^{47}$ became definitely established as an administrative court, with plenary power of adjudication delegated to it. Original jurisdiction has been conferred upon the court, as well as appellate jurisdiction in the case of decisions of the Conseils de préfecture ${ }^{48}$ and of other inferior administrative courts $^{49}$ which had original jurisdiction under various statutes.

It is an interesting fact that in the earlier stage of this development the decisions of the highest administrative agents, the ministers, were exempt from the original jurisdiction of the Conseil d'État. Under the doctrine of the ministre-juge certain determinations of the ministers were deemed to be in the nature of judicial pronouncements and therefore subject only to appellate review in the Conseil d'Etat. Thus for some time, these administrative officers continued to have combined administrative and judicial powers, notwithstanding the accomplished separation of functions within the administrative organism..$^{\mathbf{5 0}}$

${ }^{46}$ Hauriou, Précis, roth ed., pp. $870 \mathrm{ff} ., 886$; Bonnard, Le Contrôle juridictionnel de l'administration (1934), p. 153 ff. (Bibliothèque de l'institut international de droit public, No. VI); Esmein, Droit constitutionnel, Vol. I, p. 535 .

${ }^{47}$ See Appendix, below.

${ }^{49}$ First established in the year VIII.

40 Appendix, below; Laferrière, Vol. I, p. 2 I 5 ff.; Berthélemy, Traité, p. 27 ; Duguit, article, 29 Pol. Sci. $Q .385$ a t 389.

${ }^{s 0}$ Laferrière, Vol. I, p. $450 \mathrm{ff}$.; Dareste, Les voies de recours contre les actes de la puissance publique (1914), p. 54, note 2; Hauriou, Précis, roth ed., pp. 405, note 1, 887, note; Berthélemy, Traité, pp. 1 107-1 109.

\section{APPENDIX}

The most important administrative courts, under the system in force, are the Conseil d'Etat and the Conseils de préfecture. The former is a court of general jurisdiction and the latter are courts of limited jurisdiction. Waline, Manuel élémentaire de droit administratif (1936), p. 59 ff.; Berthélemy, Traité, p. $1107 \mathrm{ff}$.

The supreme administrative court is known as the Conseil d'Etat. But that name has a far broader significance, which it may be well to sketch briefly. (For a more detailed description, see Waline, pp. 59-72; Berthélemy, Traité, pp. $147-156$. 
The Conseil d'Etat is also the administrative advisory council of the ministers. In this capacity it advises the administration at the voluntary or statutory request of the latter. Although the government is generally not bound by the advice of the Conseil, this must be obtained preceding the promulgation of all regulations required under a statute. There are a certain number of other instances where the obligation to request the advice of the Conseil is specifically prescribed. On the other hand, in a few matters the law does not permit the administration to take action contrary to the advice of the Conseil, as for instance in connection with the refusal of naturalization papers (under the special conditions of art. 8, Civil Code). Furthermore, the Conseil may be called upon to give its advice or to prepare a draft of a statute which the administration intends to introduce. However, Waline (Manuel, p. 67) regrets that the Conseil in fact is no longer consulted on proposed legislation. And again under specific statutory provisions, the Conseil hears administrative appeals from determinations of inferior authorities.

For the performance of these administrative functions the Conseil d'Etat utilizes a large, well-trained personnel. There are thirty conseillers en service ordinaire, and thirty conseillers en service extraordinaire. The latter belong to the various departments of the ministers and have a voice only in the deliberations concerning their respective departments. The ministers themselves may participate in the discussions and deliberations of the affairs concerning their individual ministries (departments), though actually they do not make use of that right.

All matters coming before the Conseil (officially presided over by the "Keeper of the Seal," who is also the Minister of Justice, but actually presided over by the Vice-President) are prepared by the lower personnel, consisting of thirtynine maîtres des requêtes and forty-four "auditors." The latter are subdivided into twenty auditors of the first class and twenty-four of the second class.

Beginning at the bottom, the second class auditors are selected by members of the Conseil through competitive examinations of applicants twenty to twentysix years old. They must be well trained in the law and are to form the "juristic element" in the Conseil. (Waline, p. 6r.) Auditors of the first class are exclusively taken from among the former, not less than twenty-five nor more than thirty-four years of age. Three-fourths of the "masters," at least thirty years old, must be recruited from among the first class auditors, and the remainder from administrative functionaries with at least ten years' service (thus forming an element of mixed origin, scholars and practitioners). (Waline, p. 62.) The thirty "ordinary councilors" must be at least forty years old and must retire at seventy-five. Two-thirds of them must have been masters, and the remaining third preferably former high officials of the administration. They are nominated by the Council of Ministers. The thirty "extraordinary councilors" are active high officials (directors) and are ex officio representatives of their ministries in the Conseil. (Waline, p. 62; Berthélemy, Traité, p. 151.)

The administrative work of the Conseil is assigned to the three administrative sections into which it is divided according to subject matter. (See the "decree" of July 24, 1934, modifying the organization of the Conseil d'Etat.) In some matters two of the sections may act jointly, and again, other matters (for example, matters of special importance, or at the request of a minister) may come before the plenum (Assemblée générale) of the Conseil.

In addition to the administrative functions and the corresponding divisions of the Conseil d'Etat, it has separate judicial functions; the latter are given to a special judicial section known as the section du contentieux. It is this administrative court which is commonly and indiscriminately referred to as the Conseil 
d'Etat. The section comprises a presiding member and twelve Conseillers d'État en service ordinaire; to these may be added four councilors from the administrative sections. Twenty-eight masters and thirty auditors serve as commissaires $d u$ gouvernement and rapporteurs to the eight subsections into which the section is divided. According to importance, the cases will be heard and decided by ( $\mathrm{I})$ the assemblée plénière du contentieux, i. e., the vice-president of the Conseil d'Etat, the president of the judicial section, the presiding members of the subsections, and three councilors from the administrative sections; (2) the judicial section, i. e., its president and the presiding members of the subsections; (3) one of the senior subsections (five to eight in number, and each composed of two councilors and a master or an auditor) which specialize in routine matters (pensions, elections, fiscal affairs, etc.); (4) two of the subsections combined. The individual subsections, having one to four members, have no power of decision and hence only prepare a case for judgment. A subsection, or the section, of its own motion or that of the vice-president, the section-president, or the commissaire du gouvernement, refers the case before it to the judicial section or the plenary assembly.

The reorganization of 1934 is criticized because of the reduction of the judicial personnel, which is unfavorable to the expeditious handling of cases. Also it admits the cumulation of administrative and judicial functions in case of the four members which are recruited from the administrative sections. However, no councilor may participate in the adjudication of a matter in which he acted previously in an administrative capacity.

As to tenure, the members of the Conseil d'Etat are nominated and removable by decree of the Council of Ministers. But actually they seem almost irremovable. Waline (p. 66) refers to an attempt to recall the vice-president in 1924 which the government abandoned under the pressure of public opinion.

The Conseils de prefecture have changed in structure materially with the recent reforms. (Waline, p. 76.) The laws ("decrees") of September 6 and 26, 1926, May 5, 1934, and July 19, 1935, contributed greatly to improve their standing as judicial bodies. Changes in the selection and a substantial reduction of the administrative element in the personnel aided the purposes of their reorganization. The prefects are no longer members of these tribunals, which are now composed of four councilors and a president, nominated by the Minister of the Interior. The number of these Conseils has been reduced so that there is now one to every three or four départements, instead of one for each. Since this tended to place the courts at a greater distance from those seeking their protection, the new law makes provision for a conseiller délégué who goes from one department seat to the other to adjudicate matters of lesser importance.

The councilors are divided into three classes. The third class is selected through competitive examinations of law graduates. Three-fourths of the second and first class members are recruited by advancements in the respective lower classes.

The jurisdiction of these "inter-departmental councils of prefecture" is limited by statute to specific controversies; for instance, controversies arising in connection with the construction, maintenance, or operation of public works, direct taxes, etc.

There are a number of other administrative courts of special jurisdiction (Waline, p. $80 \mathrm{ff}$.) : the judicial councils for the colonies; the court of accounts, which audits and adjudicates all public accounts; the special courts for Alsace-Lorraine; the Superior Council of Public Instruction, and the Councils of Revision, determining the duty to do military service. 


\section{Chapter II}

\section{Comparative Significance of the Separation of Powers for Jurisdiction to Review Administrative Acts}

$7 \mathrm{HE}$ doctrine of the separation of powers, like governmental theory in general, is subject to qualification 1 in its application. Conceivably, those who first extolled its merits hoped that they had found a solid and immovable foundation upon which an enduring form of government might safely be built. But if they did so hope, they misjudged the texture of their precept. In fact, the doctrine has proved to be of extraordinary elasticity, giving way easily to pressure and capable of ready adaptation to political, economic and social needs.

In France, the absolute separation of powers, as well as its corollary, the attempted strict differentiation of the administrative and judicial agencies, almost at the very beginning were recognized as neither practical nor wholly desirable. Moreover, the immediate political need for differentiation vanished into a more and more remote past. Cooperation, rather than separation, of the departments of government became a watchword. ${ }^{1}$ It is therefore not astonishing that both the process of formation and the outline of the area in which judicial and administrative action meet and overlap are of a complicated pattern.

${ }^{1}$ Esmein, Eléments de droit constitutionnel français et comparé, 7 th ed. (1921), Vol. 1., pp. 467-70; Duguit, Traité de droit constitutionnel, 2d ed. (1923), Vol. 2, pp. 514-42, Vol. 3, p. $29 \mathrm{ff}$; Duguit Etudes de droit public (1901), Vol. 2, p. $281 \mathrm{ff}$; Jèze, Les principes généraux du droit administratif, 3d ed. (1925), pp. 257-58, 264-68, 309-10; Berthélemy, Traité élémentaire de droit administratif, 1 3th ed. (1933), p. 15-16. 
The enactments of the revolutionary government embodying the postulate of absolute freedom of the administrative agencies from interference by the courts left the administrative to judge its own actions. ${ }^{2}$ At the beginning this principle was unaccompanied by the idea of administrative courts, but in the course of time "judicial"3 protection against administrative action emerged. The administration active, with a system of appeals within its hierarchy, became distinguished from the juridiction administrative, i. e., the administrative courts.

It should be observed here that the 1938 Report of the Special Committee on Administrative Law of the American Bar Association, ${ }^{4}$ citing Professor Bonnard's treatise on the droit administratif, ${ }^{5}$ does not do justice to the historical reason for the "spirit of hostility [of the civil courts] to administrative action." "The explanation offered in the committee's report seems to rest upon a misconception. For the French system, with now fully developed "judicial" review by special courts, is not apt to arouse the "jealousy of courts manned by judges" because "of any falling short of hearing both sides fully." ?

With the development of the new system of adjudicating administrative controversies, and particularly under the influence of the Conseil d'Etat, the principle of differentiation

${ }^{2}$ Laferrière, Traité de la juridiction administrative et des recours contentieux (1896), Vol. 1, pp. 14, 185.

"The use of the term "judicial" in connection with the administrative courts is necessary to distinguish the judicially conducted review by these courts from administrative review at the instance of the various administrative agencies themselves. "Judicial review" under the French system therefore denotes not only the reviewing function of the ordinary courts, but that of the administrative courts as well. However, in order to avoid confusion, "judicial review" will be used hereafter only in the sense in which it is understood in this country, $i$. e., review by the ordinary courts.

- 63 Rep. A. B. A. (1938) 331 ff.

- Bonnard, Précis de droit administratif (1935), pp. 1 10-1 1 (the American Bar Association citation to pp. 79-80 is apparently to a different edition).

- 63 Rep.A.B.A. (1938) 331 at 341 .

Ibid. 
of agencies became attenuated. The forerunners of a changing attitude have been dated as far back as $1806 .^{8}$ The memory of prerevolutionary conditions gradually lost its force in shaping policies, and this resulted directly in a relaxed interpretation of the separation of powers and its corollary. Consequently, the administrative determinations in some instances ceased to be binding upon the ordinary courts, and in several classes of cases cognizance of administrative acts has been restored to those courts. The area of administrative jurisdiction contracted, and its contours became less rigid, as it came to be recognized that the fact that an act was administrative or originated with an administrative agency or had been performed in the public interest was not sufficient ground to withdraw that act completely from the jurisdiction of the ordinary courts. ${ }^{9}$ Other factors must be present before the doctrine of differentiated agencies becomes operative and reserves the act for the administrative courts.

In its outward appearance the resultant French régime administratif differs materially from the administrative system that has developed in the United States. In France fear of the recurrence of prerevolutionary experiences caused an adoption of Montesquieu's idea of the separation of powers with especial emphasis upon a strict differentiation of the administrative and judicial agencies. Under the fundamental law, all administrative action henceforth was exempt from inquiry by the judicial courts. In time, a separation of the judicial from the administrative functions took place within the administrative branch of the government through the organization of administrative courts and the consequent distinction of the

'See Hauriou, Précis ille droit administratif et de droit public, roth ed. (1921), p. 874, 12th ed. (1933), p. 344.

- Aucoc, Conférences sur l'administration et le droit administratif, $3 \mathrm{~d}$ ed. (1885), Vol..7, pp. 473, 481; Laferrière, Vol. I, p. 471 ff.; Hauriou, Précis, Ioth ed., pp. 464-65, note 2, p. 874 ff.; 12th ed., pp. 459-60; Berthélemy, Traité, pp. 23, 1099-1106; Bonnard, Précis, p. 150 ff.; Waline, Manuel élémentaire de droit administratif (1936), p. $42 \mathrm{ff}$. 
administration active from the juridiction administrative. The decisions of the latter in reviewing the acts of the former, however, are "administrative acts" in the sense that they can never be subject to attack in the ordinary courts. In other words, the pronouncements of both sets of courts have identical force and the same degree of finality.

In the United States the evolution of administrative law, in so far as it depends upon the influence of the separation of powers, looks back upon a different history. At the time of the adoption of the Constitution, its framers were apprehensive, not of past experience, but of the dangers lurking in the "novel experiment of popular rule on a large scale." ${ }^{10}$ In the - debates of the Federal Convention of I 787 great stress was laid upon the doctrine of separated powers as expounded by Montesquieu. But the proponents of the doctrine extolled its merits as a means of protection against legislative encroachments upon fundamental rights of liberty and property. Thus the separation of powers, though derived from the same philosophical source, was endowed with a meaning divergent from that attributed to it contemporaneously in France. Removed from its native environment, no difficulty was encountered in giving it a construction favorable to the postulate of equal dignity of the three powers. The judiciary could be erected into a coordinate branch of government in order that it might function as a check upon each of the other branches. The incidental power of the ordinary courts in this country to review administrative action became as necessary and inevitable a constitutional mandate as the principle of judicial noninterference in France.

${ }^{10}$ See the comprehensive treatment by Malcom P. Sharp, "The Classical American Doctrine of 'The Separation of Powers," " 2 U. Chi. L. Rev. (1935) 38 5; Professor Sharp very clearly demonstrates that the main objective was to guard against legislative tyranny (pp. 393, 396, 397, 408, 420, 434-435). See also Fuchs, "Concepts and Policies in Anglo-American Administrative Law Theory," 47 Yale L. J. (1938) 538 at 541 ff.; Report of the Special Committee on Administrative Law, $63 \operatorname{Rep}$. A.B.A. (1938) 331 at $352 \mathrm{ff}$. 
The basic considerations, therefore, which led to the adoption of Montesquieu's theory in the two countries envisaged the solution of widely differing political problems. In France one of the most pressing concerns was to make the administrative independent of the judiciary, while this country felt the need of an independent judiciary to check legislative excesses. ${ }^{11}$ In each instance the adoption of the doctrine of the separation of powers was accompanied by an interpretation which fitted it to the particular demands. In France this resulted directly in a denial to the ordinary courts of all power to interfere with administrative action. Conversely, in the United States a nominally coordinated, and in fact supreme, judiciary was assigned a task which of necessity carried with it the power to scrutinize the acts of all administrative agencies.-

However, comparison does not for this reason come to an impasse. In the constant flux of political conditions, the original content of the doctrine of the separation of powers, both here and in France, has changed imperceptibly. Through the formulation of exceptions and the devising of distinctions it has been modified and readapted to changing conditions. The intended strict differentiation of the administrative and the judiciary in France very soon became attenuated. Gradually the ordinary courts, even though only in a limited sense, returned to the adjudication of acts originating with administrative officials and agencies, as will be demonstrated in detail later. Similarly, the rigid conception in the United States of three independent departments, exercising the functions named after the three corresponding powers, also had to give way to more workable compromises. Aided by strict interpretation, "we had carried to the extreme a system of judicial interference with administration. Something very

\footnotetext{
${ }^{11}$ At the same time a strong executive was favored, not in regard to the judicial power, but to serve with the latter to counteract the power of the legislature. Sharp, article, 2 U. Chi. L. Rev. 385.
} 
like a paralysis of administration by judicial order or judicial review was an everyday spectacle."12 Paradoxically a situation was thus created which was closely analogous to the very conditions which the differentiation of agencies in France had been instituted to combat. A reaction proportioned to the increasing needs for administrative handling of new social and economic problems was inevitable. In turn, the ensuing increase in administrative activity has brought forth insistence upon a reinterpretation of the separation of powers doctrine in regard to administrative agencies so as to require "a segregation of their judicial functions." ${ }^{13}$ Unmistakably, divergent forces are constantly at work which necessitate sporadic interpretative readjustments in order to balance accrued surpluses or deficiencies in administrative and judicial powers. These competitive forces are the interests of the public, on one hand, and private interests, concerned with the protection of personal liberty and property rights, on the other. ${ }^{14}$ In the United States the separation of powers in its constitutional setting has placed the collective interest represented by the administration at a disadvantage. In France the basic situation is reversed, and indeed the French courts have continued to reaffirm the differentiation of judicial and administrative agencies as originally conceived. But neither the privileged position of the administration in France nor the far-reaching powers of the constitutional courts in this country have withstood the pressure of certain identical political and social forces. Jurisdiction to review administrative acts has had to be

\footnotetext{
${ }^{12}$ Report of the Special Committee on Administrative Law, ${ }_{3}$ Rep. A. B. A. (1938) 331 at 353.

${ }^{23}$ Report of the Special Committee on Administrative Law, 6r Rep. A. B. A. (1936) 720 at 725 , and quotation at 730 : "In this situation the committee feels justified in looking beyond the particular turn given to the doctrine by the Supreme Court decisions, and in appealing to what seem to be its underlying implications and its natural corollaries for the sound and efficient administration of justice."

${ }^{14}$ Fuchs, article, 47 Yale L. J. 538 at 559.
} 
redefined, and it will be the object of the following chapters to sketch the evolution and to survey the meandering course of the imaginary line of demarcation separating the spheres of administrative and judicial action in France.

Before proceeding to the discussion of the jurisdictional details themselves, it is necessary that an account be taken of the machinery which has been devised for the enforcement of the constitutional mandate of separated powers. Perhaps the thought of an independent mechanism for maintaining the differentiation of judicial and administrative authority does not so readily occur in the United States. The constitutional scheme which appointed the courts its guardians thereby subjected not only legislative but also administrative acts to the scrutiny of those courts with respect to all constitutional inconsistencies. The limits of their own powers in regard thereto are consequently self-determined. Not so in France. There the prohibition "to interfere in any manner" with the administration rendered the ordinary courts wholly unfit to enforce administrative independence. Still, a mechanism for safeguarding it was essential.

The Conflit. At the outset of the new regime, the solution of the problem of securing the administrative against anticipated usurpations by the judiciary was fashioned after the procedure which formerly had served the Crown. The latter could, and often did, withdraw from the courts ${ }^{15}$ controversies in which it was interested. Thus, the administrative was empowered by legislation to divest the courts of matters allegedly falling within the administrative jurisdiction. ${ }^{16}$ The power was first lodged in the executive, although at various times it was coupled with a requirement of concurrence by the

${ }^{25}$ By way of évocations, supra, chap. I, at note $3 \mathrm{I}$.

${ }^{26}$ Hauriou, Précis de droit administratif et de droit public, 1 oth ed. (1921), p. 879, 12th ed. (1933), p. $336 \mathrm{ff}$., and bibliography there; Berthélemy, Traité élémentaire de droit administratif, 13th ed. (1933), p. 1086 ff.; Bonnard, Précis de droit administratif (1935), p. 164. 
legislature, or of advice by the Conseil d'Etat, which later became the sole judge of jurisdictional conflicts. ${ }^{17}$ Further developments, in which abuses of this power by the government ${ }^{18}$ played a part, ultimately led ${ }^{19}$ to the organization of a neutral agency with exclusive jurisdiction to determine such conflicts.

The Tribunal des conflits. The Tribunal des conflits, which has thus been entrusted with the resolution of jurisdictional controversies, has the appearance of an impartial tribunal, being composed of judges recruited in equal numbers from among the members of both the administration (Counseil d'État) and judiciary (Cour de cassation), and presided over by the Minister of Justice. Nevertheless, it continues to rest on the theory of a unilateral protection of the administration against the civil courts. This is evident in the fact that the Tribunal des conflits acts only at the instance of certain administrative officials, the prefects. These officers alone can élever le conflit, i. e., resort to the Tribunal for the purpose of divesting a judicial court of jurisdiction. There is no corresponding right in favor of the judicial authorities. ${ }^{20}$

The unilateral right to assert a conflict of jurisdiction and the ensuing judicial determination of the limits of competency of the respective judicial or administrative agencies are the primary safeguards afforded by the French system for the principle of the differentiation of agencies. Protests by the

${ }^{17}$ Laferrière, Traité de la juridiction administrative et des recours contentieux, 2d ed. (1896), Vol. I, pp. 21-25; Aucoc, Conférences sur l'administration et le droit administratif, 3d ed. (1885), Vol. 1, p. 709 ff.; Ducrocq, Cours de droit administratif, 7th ed. ( 1898 ), Vol. 3, p. 296 ff.; Jacquelin, Les principes dominants du contentieux administratif ( 1899 ), p. 54 ff.; Berthélemy, Traité, p. ro8 7; Laroque, "Les conflits d'attributions" 49 R.D.P. (1932) 5; Appleton, Traité élémentaire du contentieux administratif ( 1927 ), p. $50 \mathrm{ff}$.

${ }^{18}$ Infra, chap. VIII.

${ }^{19}$ In 1849 and again in 1872 .

${ }^{20}$ Hauriou, Précis, 1 oth 'ed., pp. 879-880, 12 th ed., pp. 336-37; Berthélemy, Traité, p. 1088. Cf. also Duguit, Traité de droit constitutionnel, $2 \mathrm{~d}$ ed. (1923), Vol. 3, pp. 53-58. 
prefects concerning jurisdiction over controversies pending in the ordinary courts give rise to what are known as "positive conflicts." ${ }^{21}$ A second sanction of the differentiation of agencies exists in the requirement that the highest judicial and administrative tribunals, i. e., the Cour de cassation and the Conseil d'État respectively, must of their own motion annul the acts of inferior agencies of the respective hierarchies whenever the acts of the one constitute encroachments upon the jurisdiction of the other. Furthermore, the jurisdiction of the Tribunal des conflits may be invoked by the parties to a suit for the determination of "negative conflicts." This type of conflict arises when both the administrative and the judicial courts have declined to take cognizance of a controversy. ${ }^{22}$ In such cases the office of the Tribunal des conflits is to protect litigants against a denial of justice. In deciding in these circumstances to which court its "mandamus" should be addressed, the Tribunal again acts as the custodian of the differentiation of agencies, the principle by which its decisions must be guided. Comparatively recently, ${ }^{23}$ the jurisdiction of the Tribunal des conflits has been extended to conflits de décision. The enabling statute confers power upon the Tribunal to make an independent decision on the merits of any case in which an administrative and an ordinary court have rendered inconsistent decisions. Previously, such situations actually resulted in a denial of justice. ${ }^{24}$

The foregoing analysis presents three aspects of the doctrine of the separation of powers which are of primary im-

${ }^{21}$ Laferrière, Vol. I, p. 472 ; Berthélemy, Traité, p. 1088; Bonnard, Précis, p. I62; Waline, Manuel élémentaire de droit administratif (1936), p. 36 .

${ }^{22}$ Appleton, p. 79; Berthélemy, Traité, p. 1096; Bonnard, Précis, p. I65; Waline, Manuel, p. 40.

${ }^{23}$ Law of April 20, 1932.

${ }^{24}$ Bonnard, Précis, pp. 166-67; Bonnard, Le contrôle juridictionnel de l'administration ( 1934 ), p. I 75, note I (Bibliothèque de l'institut international de droit public, No. VI); Waline, Manuel, p. 40; Appleton, Supp., pp. I 1-1 3. See Matter of Rosay D. H. 1933.336. 
portance from the viewpoint of jurisdiction to review administrative acts. First, the historical and political atmosphere determining the original content of the doctrine of separate powers; second, the resultant relation of the administrative and judicial departments of government; and, thirdly, the mechanism designed both to maintain and to adjust the constitutional scheme under changing conditions. The review powers of the French courts will now be developed in the light of these factors. 


\section{PART II}

\section{THE REVIEW POWERS}

\section{OF THE}

\section{ADMINISTRATIVE COURTS IN FRANCE}




\section{Chapter III \\ Recourse for Excess of Power}

\section{A. HISTORY OF ANNULMENT OF ADMINISTRATIVE ACTS IN THE CONSEIL D'ÉTAT}

T $N$ France the Conseil d'État alone has power to annul administrative acts ${ }^{1}$ it alone can dispense the remedy 1 known as the recours pour excès de pouvoir, ${ }^{2}$ which, if successfully prosecuted, leads to the setting aside of the administrative determination of which complaint is made. ${ }^{3}$ Among the available methods of obtaining relief from administrative action, ${ }^{4}$ this method of direct attack ${ }^{5}$ is peculiar to the French system.

The fact that petitions for annulment of administrative decisions come within the exclusive jurisdiction of the highest administrative court is significant, not only in the light of the doctrine of differentiated administrative and judicial agencies, but also in view of the evolution of the remedy itself. The recours pour excès de pouvoir is not, as might be sup-

${ }^{1}$ French law commonly distinguishes four different objects with a view to which the administrative courts may exercise their jurisdiction: annulment (contentieux de l'anmulation), (2) review on the merits (contentieux de pleine juridiction), (3) interpretation of administrative acts (contentieux de l'interpretation) and (4) application of penal sanctions (contentieux de la repression). See the analysis of this classification by Professor Waline in article, 52 R. D. P. (1935) 205.

${ }^{2}$ There is one unimportant exception under the law of May 5,1934 . See Waline, Manuel élémentaire de droit administratif (1936), p. I 14 .

'Laferrière, Traité de la juridiction administrative et des recours contentieux, 2d ed. (1 896), Vol. 2, p. 391 ff.; Hauriou, Précis de droit administratif, roth ed. (1921), p. 420 ff.; 1 2th ed. (1933), p. 401 ff.; Berthélemy, Traité élémentaire de droit administratif, I $3^{\text {th }}$ ed. (1933), p. $1126 \mathrm{ff}$.; Bonnard, Le contrôle juridictionnel de l'administration (1934), p. $\mathrm{I}_{7} \mathrm{ff}$. (Bibliothèque de l'institut international de droit public, No. VI); Bonnard, Précis de droit administratif (1935), p. 192 ff.; Waline, Manuel, p. 115 ff.; Appleton, Traité élémentaire du contentieux administratif (1927), p. 525 ff., Supp. (1936), p. $86 \mathrm{ff}$.

'See Dareste, Le voies de recours contre les actes de la puissance publique ( 1914 ).

'Dareste, p. $288 \mathrm{ff}$. 
posed, a method of attack originally created by statute as an integral part of the post-revolutionary scheme of public administration. On the contrary, it was essentially developed through precedent in the Conseil d'Etat, proceeding much like a court of equity. ${ }^{6}$ In a sense, the evolution of the remedy was completed in 1872 with the passage of article 9 of the law of May 24th of that year giving legislative sanction to the jurisdiction of the Conseil over petitions for annulment. On the other hand, there are several earlier enactments which had mediately influenced and contributed to the development of the recours. ${ }^{\text {? }}$

Before the Revolution, the theory of justice retenue permitted the chief executive to set aside acts of subordinate administrative officers, and in doing so he often relied upon the advice of his council, the Conseil $d u$ roi. ${ }^{8}$ It has been observed in an earlier chapter that the theory of justice retenue, with one exception, ${ }^{9}$ prevailed until I 872 , and it must also be remembered that the Conseil d'Etat did not become an independent court until several decades after the Revolution. Thus, in its capacity as an advisory body, it could in the name of the chief executive invalidate acts of inferior agencies which had exceeded their powers. During this period the Conseil d'État, as the appointed guardian of the differentiation of agencies, was therefore equipped with a double-edged weapon. Through the exercise of its jurisdiction over conflicts ${ }^{10}$ it could abate usurpations by the ordinary courts, and at the same time it possessed the power to annul the acts of its own subordinates, primarily in order to keep them within the limits constitutionally set to their powers. ${ }^{11}$

- Laferrière, Vol. 1, pp. 1 7-18, Vol. 2, p. 402 ff.; Berthélemy, Traité p. 1126 ; Bonnard, Précis, p. 192 ff.; Hauriou, Précis, 12th ed., p. 406.

${ }^{7}$ Laferrière, Vol. 2, pp. 402-406.

${ }^{8}$ Supra, chap I, p. 9.

- Supra, chap I, p. I5.

${ }^{10}$ Supra, chap II, p. 26.

II As to technique, the Conseil d'Etat has largely paralleled the Cour de cassation in matters of excess of power by the judicial authorities. Laferrière, Vol. 2, pp. 397-402. 
Strictly speaking, annulment by the Conseil d'État, prior to its establishment as an administrative court, was not a judicial appraisal but an administrative disapproval ${ }^{12}$ by the highest administrative body of the determinations of inferior officials. The original character of the recourse for excess of power was that of a nonjudicial, administrative appeal, a recours hiérarchique. ${ }^{13}$ Even at the present time, where the recours is taken to a judicial body, i. e., to a modern administrative court, it still partakes of some of its former nature. However, it differs from the recours hiérarchique ${ }^{\mathbf{1 4}}$ in that it can lead only to the annulment, not to the reformation, of the act attacked. In this latter respect the recourse for excess of power is a judicial appeal as it is understood in this country. ${ }^{\mathbf{1 5}}$

\section{B. SUBSTANTIVE AND PROCEDURAL FEATURES OF THE}

RECOURSE FOR EXCESS OF POWER

\section{Grounds for and Nature of the Appeal}

A recourse to the Conseil d'Etat demanding the annulment of an administrative determination can be validly formulated by anyone whose legitimate interests are directly and adversely affected thereby. The Conseil d'État, through continued extensive interpretation, has gradually broadened the availability of the remedy. ${ }^{16}$ The grounds upon which it may

${ }^{12}$ For the specific reason of excess of power.

${ }^{23}$ Laferrière, Vol. 2, p. 4 I 3 ; Dareste, p. 304 ff.

${ }^{14}$ Laferrière, Vol. 1, p. 446 ff.; Dareste, p. 289 ff.; Hauriou, Précis, roth ed., p. $106 \mathrm{ff}$., 12 th ed., p. $80 \mathrm{ff}$. Hauriou (ibid.) further distinguishes the recours hiérarchique from the recours gracieux. The latter is the complaint lodged with an authority regarding its own action, and the term emphasizes the discretion of that authority to reconsider its action.

${ }^{16}$ Prentis v. Atlantic Coast Line Co., (rgo8) 2 I U. S. 2 ro; Federal Radio Commission v. General Electric Co., (1930) 28 I U. S. 464.

${ }^{1}$ Waline, Manuel, p. $120 \mathrm{ff}$. See also Laferrière, Vol. 2, p. 436; Hauriou, Précis, roth ed., p. 436 ff., 1 2th ed., p. 424 ff.; Berthélemy, Traité, p. 1030; Appleton, p. 554 ff., Supp., p. 87 ff.; Bonnard, Précis, p. $202 \mathrm{ff}$.

Although a mere interest nominally will not support a direct attack upon an administrative determination in this country, some of the asserted proprietary rights which have sufficed for the judicial invalidation of zoning ordinances present a fair analogy. Cf. Nectow v. City of Cambridge, (1928) 277 U. S. 183. 
be prosecuted are collectively designated as "excess of power" and are classified as: (a) want of statutory authority (incompétence), (b) disregard of statutory formalities (vice de forme), (c) violation of rules of law (violation de la loi), and (d) abuse of power (détournement de pouvoir). ${ }^{17}$

The control over administrative acts through the power to annul, although judicial in form and effect, must nevertheless be viewed as exercised chiefly in the interests of administrative efficiency. In the hands of an administrative court it is not a control in the sense of a check upon the power of one branch of government by another. The administrative department itself finally adjudicates the validity of determinations which its agents have made. If they have exceeded their powers, the actions of the administration active are censured by way of annulment. ${ }^{18}$ The dual purpose of the recourse for excess of power, envisaging both the promotion of administrative efficiency and the safeguarding of private interests, has interesting consequences. Even though the proceeding can be instituted only by a private party seeking protection against an allegedly injurious act, the annulment which may ensue operates erga omnes. ${ }^{19}$ The proceeding is directed against the act itself, thus being in rem and not against a person. ${ }^{20}$ Indeed, the adversely affected interest which is required to support a recourse is not the primary concern of the administrative, although this prerequisite serves to eliminate from consideration complaints not made in good faith. ${ }^{21}$ The relief afforded by an annulment is incidental.

${ }^{17}$ Laferrière, Vol. 2, p. 496 ff.; Hauriou, Précis, roth ed., p. 448 ff., I 2 th ed., p. 424 ff.; Berthélemy, Traité, p. 1136 ff.; Appleton, p. 591 ff., Supp., p. $90 \mathrm{ff}$.; Bonnard, Précis, p. 216 ff.; Waline, Manuel, p. $140 \mathrm{ff}$.

${ }^{18}$ There is a marked trend to broaden the use of the recourse for excess of power as a means of judicial censure by the highest administrative court of illegal acts of the administration active. See Appleton, p. 596; Alibert, note accompanying two decisions (Plet and Pérignon) of the Conseil d'Etat reported in S. 1936.3.97, condensed in 54 R. D. P. (1937) 146.

${ }^{10}$ Laferrière, Vol. 2, pp. 568, 573 ; Hauriou, Précis, roth ed., p. 462.

${ }^{20}$ Dareste, p. 307; Hauriou, Précis, roth ed., p. 414, 12th ed., p. 394; Berthélemy, Traité, p. I 138.

${ }^{2}$ Berthélemy, Traité, p. 1131 . 
In keeping with the "impersonal" nature of annulment proceedings, an informal written protest by the party prosecuting the recourse is sufficient, representation by counsel is dispensed with, and the costs are negligible. ${ }^{22}$ On the other hand, the recourse for excess of power is not available to an interested party to whom a concurrent remedy, a "parallel recourse," is open..$^{23}$ Administrative appeals (recours hiérarchiques) are not concurrent remedies in this sense, and therefore annulment by the Conseil d'État and strictly administrative relief in respect to the same determination are not mutually exclusive. ${ }^{24}$ Conversely, a recourse for excess of power may be had without first exhausting the administrative appeals; or, as the principle is usually stated, the former remedy is open omisso medio. In other words, the recourse for excess of power may; but need not, be an appeal from a decision reviewing the original determination of an inferior administrative agency. ${ }^{25}$

${ }^{22}$ Berthélemy, Traité, p. 11 38; Hauriou, Précis, roth ed., p. 414, 12th ed., p. 394 .

${ }^{33}$ The recours parallele must be a complete remedy in an administrative court other than the Conseil d'Etat, or in a civil court; a mere possibility of collateral attack by way of defense to a prosecution is insufficient. In this respect there has also been a growing tendency to enlarge the use of the recourse for excess of power. The obstacle of a concurrent remedy has been minimized by requiring that it must afford relief at least equivalent to that flowing from annulment. The rule is obviously comparable to the principle by which equity may interfere where there is no adequate remedy at law. Waline, Manuel, pp. 136-40. See also Laferrière, Vol. 2, p. 474 ff.; Dareste, p. 423 ff.; Hauriou, Précis, roth ed., p. 444 ff.; Berthélemy, Traité, pp. 11 32-33; Bonnard, Précis, pp. 209-1 I.

${ }^{24}$ Hauriou, Précis, roth ed., p. 443, note 2.

2o Laferrière, Vol. 2, p. 451 ; Dareste, p. 306; Hauriou, Précis, 12 th ed., p. 409.

The recourse for excess of power must be begun within two months from the date of actual or constructive notice of the determination sought to be annulled by the interested party. On the other hand, administrative appeals are not limited in point of time. However, the latter must be entered within the two-month period if the right to the former is to be preserved. In this case judicial annulment may be applied for within two months after the disposition of the hierarchic recourse. Laferrière, Vol. 2, p. 468 ; Berthélemy, Traité, p. I 133 ff.; Hauriou, Précis, 1 oth ed., p. 442, 1 2th ed., p. 429; Waline, Manuel, p. 132 ff. See also the note by Alibert, accompanying a decision of the Conseil d'Etat of January ro, 1930, S. 1930.3.41, $48 R$. D.P. (1931) 163, concerning certain methods of circumventing the two-month limit for the recours en annulation. 


\section{The Subject Matter of the Appeal}

An attack in the form of a recourse for excess of power can be directed only against an administrative determination or decision. French doctrine, insisting that administrative agencies having determining powers ${ }^{26}$ must always proceed by way of "decisions which are susceptible of immediate execution," has developed the concept of décisions exécutoires. ${ }^{28}$ This term is but an expression of the synthetic understanding of the administrative process. It embraces expressed or implied findings and conclusions preceding the determination, ${ }^{29}$ notice of which must be given to all interested parties. ${ }^{30}$ Hauriou $^{31}$ in familiar language explains the décision exécutoire as (I) requiring administrative agencies to deliberate before taking action and (2) furnishing the necessary foundation for court review. These décisions exécutoires, as manifestations of the sovereign power by which "the administrative publicly asserts its right and its intention to proceed in a stated manner, ${ }^{\mathbf{3 2}}$ are administrative acts par excellence. In other words, they are declarations of policy, which, under the principle of differentiated agencies, are protected against any interference by the ordinary courts. The recourse for excess of power, essentially designed for the annulment of administrative determinations, thus falls peculiarly within the exclusive province of the administrative courts.

20 These include the chief executive, the ministers, prefects and underprefects; departmental councils and commissions; municipal councils and the mayors.

${ }^{27}$ Hauriou, Précis, roth ed., p. 393 ff., 1 2 th ed., p. $371 \mathrm{ff}$., and cases cited.

${ }^{28}$ Hauriou, ibid.; Waline, Manuel, p. 439 ff. See also Laferrière, Vol. 2, p. $427 \mathrm{ff}$.

${ }^{20}$ The usual form of décision is a written order, although it may be verbal only and transmitted by telephone. Waline, Manuel, pp. 440-4I, and cases cited.

${ }^{80}$ Notice must be personal or by publication; constructive notice is rarely deemed sufficient. Waline, Manuel, p. 131 and cases cited.

${ }^{32}$ Précis, roth ed, p. 393 ff., 1 2 th ed., p. 371 ff.

Hauriou, Précis, roth ed., p. 394. 
It should be observed, however, that even annulment by the Conseil d'Etat is in a sense considered as judicial interference with administration. Recourses for excess of power therefore ordinarily do not operate as a supersedeas. Prompt administrative action must not be impeded, and only in exceptional situations in which administrative expediency and private interest coincide are annulment proceedings permitted to stay the execution of the order attacked. ${ }^{33}$

${ }^{*}$ Waline, Manuel, p. 448. In time it was found that administrative officials, in order to escape the censure implicit in the annulment of their acts, avoided the formality of issuing executory orders. To safeguard against this subterfuge, the requirement of the décision exécutoire has been fortified with a double sanction. (r) Administrative officials taking affirmative action without observing the prescribed formality have been made personally liable for the consequences of the act. Hauriou, Précis, roth ed., p. 393, 12th ed., p. 371 , and cases cited. (2) If in case of action solicited by a private party the administrative agency disregards the application, petition or complaint, such inaction is deemed equivalent to an express rejection, provided it has continued over a period of four months. Art. 3 of the law of July 1 7-19, 1900; see also art. 7 of the decree of Nov. 2, 1864 . The implied negative decision then becomes subject to recourse for excess of power without any limitation in point of time. Laferrière, Vol. 2, pp. 429, 469; Berthélemy, p. 1123 ff.; Hauriou, Précis, 1 oth ed., p. $408 \mathrm{ff}$., 442, 12 th ed., p. 386 ff., 430; Bonnard, Précis, pp. $189-90$. The effect of the latter provision is particularly salutary where a hierarchic appeal has been taken after the expiration of the two months within which a recours pour excès de pouvoir might have been instituted. Except for the statute, inaction by the administrative agency to which the appeal has been addressed would leave the aggrieved party without remedy, since neither mandamus nor mandatory injunctions are possible under the French system. On the other hand, if the hierarchic superior confirms the action complained of, no new recourse lies to the Conseil d'Etat. However, if the order appealed from is revoked or modified, the disposition made constitutes a new decision which may be attacked for excess of power. Laferrière, Vol. 2, p. 462.

Compare the situation in this country where the aggrieved party has a remedy in the federal courts if administrative relief is deliberately delayed or withheld, as in the case of Oklahoma Natural Gas Co. v. Russell, (1923) 26 r U. S. 290, making an exception to the rule of Prentis v. Atlantic Coast Line Co., (1908) 2 I I U. S. 2 I 0. 


\title{
Chapter IV
}

\section{Review of Administrative Acts on the Merits}

\author{
THE ORDINARY RECOURSE
}

LTHOUGH the recourse for excess of power is an
outstanding feature of the French administrative
system, the most common method of obtaining relief from administrative action is the prosecution of an ordinary action against the particular agency, with inquiry by a court into the law and facts, and adjudication on the merits of the case. Unlike the former remedy, the latter has no characteristics which automatically limit jurisdiction to the administrative courts, and only a rigid interpretation of the differentiation of agencies could entirely oust the ordinary courts from entertaining such actions. This form of attack upon the acts of administrative agencies, generally known as the recours de pleine juridiction, ${ }^{1}$ resembles closely a civil action, and it is therefore often referred to as the recours ordinaire. ${ }^{2}$ A mere interest is no longer sufficient, and the violation of a right ${ }^{3}$ must be shown if the recourse is to be successful. Moreover, a judgment for the plaintiff may carry reformation of the act of which complaint is made, as well as indemnity or restitution.

${ }^{1}$ Laferrière, Traité de la juridiction administrative et des recours contentieux, 2d ed. (1896), Vol. 1, p. I 5 ff., Vol. 2, p. I1 5 ff.; Hauriou, Précis de droit administratif et de droit public, I oth ed. (1921), pp. $463 \mathrm{ff}$., 875, I 2th ed. (1933), pp. 458 ff., 345; Berthélemy, Traité élémentaire de droit administratif 13 th ed. (1933), p. $1120 \mathrm{ff} . ;$ Bonnard, Précis de droit administratif (1935), p. 183 ff.; Waline, Manuel élémentaire de droit administratif (1936), p. $113 \mathrm{ff}$.

${ }^{2}$ Hauriou, Précis, roth ed., p. 464, I 2th ed., p. 459.

Berthélemy, Traité, pp. 1121-1123. 
A. THEORETICAL BASIS OF JURISDICTION

\section{Authoritative Acts and Acts of Management}

It was inevitable that a complex situation should have arisen as soon as the doctrine of exclusive administrative adjudication was abandoned. In other words, the recognition that the differentiation of agencies did not, or should not, require the indiscriminate exclusion of the ordinary courts wherever action originating with an administrative agency was involved, immediately called for a basis upon which jurisdiction could be predicated. A solution was found in construing the legislation of I 790 and the year III as comtemplating nothing more than that the judicial courts should be barred from taking cognizance of acts performed in the exercise of delegated sovereign power. ${ }^{4}$ It has been said that the administrative, representing sovereignty, acts by commanding, regulating or prohibiting, as a superior would in his relations with subordinates. To this extent the judicial department, itself representing sovereignty, might be the equal of the administrative but not its superior. ${ }^{5}$ Acts of this type, but for the existence of administrative courts, could not under the French system be subject to "judicial" review. ${ }^{6}$ However, not all actions of administrative officials are of this kind. In performing their duties administrative officials must often resort to forms of action which are common to private intercourse. This is the classical distinction which the French have made between authoritative acts (actes de puissance publique or actes d'autorité), and acts of management (actes de gestion). ${ }^{7}$ The notion prevailed that the ordinary courts should be left competent

'Laferrière, Vol. I, p. 477 ff.

${ }^{5}$ Duguit, Traité de droit constitutionnel, 2d ed. (1921), Vol. I, p. 44I ff., Vol. 2, p. $521 \mathrm{ff}$.

- Berthélemy, Traité, p. 1100.

${ }^{7}$ Laferrière, Vol. I, pp. 484 ff.; Berthélemy, Traité, p. 1100. 
to adjudicate controversies arising from transactions which do not differ from similar dealings between private individuals.

In the case of a recourse for excess of power, the act attacked is always of the authoritative type. ${ }^{8}$ On the other hand, an ordinary recourse may involve one or the other form of administrative action, so that the question of jurisdiction becomes acute. In dealing with the question, the basic jurisdictional rule, whose foremost exponent was Laferrière, ${ }^{\boldsymbol{\theta}}$ seemed clearly indicated by the classification of administrative acts as authoritative acts and acts of management. Accordingly all actes de puissance publique should belong to the administrative courts as a matter of right, while all actes de gestion automatically would come within the cognizance of the ordinary courts. In other words, in case of the former, jurisdiction can only exceptionally be given to the civil courts, while jurisdiction over the latter cannot be withdrawn from these courts except by statute. ${ }^{10}$ These principles have retained much of their fundamental importance, although later doctrine, under the pressure of the increase in volume and complexity of administrative tasks, has drifted away from them in search of new criteria. However, the old mode of determining jurisdiction has never been wholly abandoned, and even contemporary writers defend it rigorously as the only logical line of demarcation, notwithstanding divergent developments over a long period of time. ${ }^{11}$

\section{The Public Service Criterion}

With the modern expansion of governmental activity and its growing importance in the solution of social and economic

${ }^{8}$ Hauriou, Précis, roth ed., p. 875 , r 2th ed., p. 344.

- Laferrière's treatise on administrative jurisdiction continues to have great authority and is frequently referred to by the courts in modern times, even though it is out of date and does not reflect the developments since 1896 .

${ }^{10}$ Laferrière, Vol. I, pp. 484-485; cf. Ducrocq, Cours de droit administratif, 7th ed. (1 897 ), Vol. 2, p. 1 o ff.

${ }^{11}$ See Berthélemy, Traité, pp. 24-25, note I, 1 100, note I; Waline, Manuel, p. 43 . 
problems, the concept of service public ${ }^{12}$ became a factor in determining the limits of the administrative and ordinary jurisdictions. It was introduced in the latter part of the last century, and, without superseding the former line of delimitation, it has had a dominating influence on the interpretation of the differentiation of agencies until the most recent times. The public service factor modifies the older rule by claiming for the administrative jurisdiction not only all acts of authority ${ }^{13}$ but also all acts of management in so far as they are directly connected with the performance of a public service. ${ }^{14}$ This reinterpretation of the principle of differentiated agencies in France runs closely parallel with the tendency to enlarge administrative finality in this country, and the real reason must be looked for in the greater aptitude of an administratively trained personnel ${ }^{15}$ to deal with technical administrative problems. ${ }^{16}$

15 The term "public service," as used in France, is a collective mode of reference to the various governmental functions or duties to the public which must be performed through the administrative machinery for the maintenance and furtherance of public safety and security, public health and order, and public welfare in general. Appleton, Traité élémentaire du contentieux administratif (1927), p. 114, gives the following concise definition: "Un service public est donc un moyen, organisé par les pouvoirs publics, de satisfaire socialement un besoin général par des procédés propres au droit administratif." This may be translated: "A public service, therefore, is a method provided by the state for the satisfaction of general social needs through proper administrative channels." Berthélemy (Traité, p. 266) classifies the services as ( 1 ) essential services, comprising the police for the maintenance of public health and order, national defense, and the management of state-owned property (p. $267 \mathrm{ff}$.); (2d) optional services, supplementing nonexistent or insufficient private initiative, including regulation of transportation, mining, forestry, agriculture, industry and commerce, public schools, encouragement and conservation of art and art treasures, social security (p. $760 \mathrm{ff}$.). Finances (budget and taxation) are treated as "ways and means" under a separate heading (p. ro29 ff.). Cf. Hauriou, Précis, roth ed., pp. $25,467 \mathrm{ff}$., I 2th ed., p. $64 \mathrm{ff}$.

${ }^{13} \mathrm{Cf}$. the decision of the Tribunal des conflits, in Sagot du Vauroux v. Fazuilhe, Rec. 1906.803.

${ }^{14}$ Bonnard, Précis, pp. $154^{-1} 55$.

${ }^{15}$ See Appendix, pp. 16-1 8, supra.

${ }^{16}$ Bonnard, Précis, p. I52; cf. Landis, "Administrative Policies and the Courts," 47 Yale L. J. 519 at 529, 535; Dickinson, Administrative Justice and the Supremacy of the Law (1927), pp. I 3-1 5; Freund, Administrative Powers over Persons and Property (1928), p. 73 ff. 
Since the injection of the criterion of public service into the jurisdictional issue in France, the guiding principles have been formulated thus: (I) The adjudication of all controversies arising from the performance and functioning of the public services must be left to the administrative courts, irrespective of whether the administrative acts involved are authoritative or managerial. (2) All acts of management not connected with the functioning of a public service come under the jurisdiction of the ordinary courts. These rules have become subject to exceptions founded on both statute and precedent. ${ }^{\mathbf{1 7}}$ However, it is interesting to observe that the late Professor Hauriou, ${ }^{18}$ who often anticipated future trends, adopted a new terminology in the 1933 edition of his treatise. Relinquishing public service as the pivotal factor, he distinguished gestion publique from gestion privée, i. e., public management from private management. This may well be taken to indicate a return to the classical juxtaposition of puissance publique and gestion. Or perhaps this latter distinction has always dominated. It would indeed be possible to say that so-called acts of management, through intimate connection with the performance of a public service, become impregnated with sovereign power.

\section{B. JUDICIAL INTERPRETATION}

\section{The Rule of the Blanco Case}

The line intended to separate the administrative from the judicial sphere of influence, and developed by the courts on the basis of the foregoing distinctions, is marked by a number of important decisions.

${ }^{17}$ Hauriou, Précis, roth ed., p. 875 ff.; Berthélemy, Traité, p. $1100 \mathrm{ff} . ;$ Bonnard, Précis, p. I 54 ff.; Waline, Manuel, p. 47 ; Appleton, p. I 14 ff., Supp., p. I 6.

${ }^{18}$ Précis, 12 th ed., p. 345 ff., $1064 \mathrm{ff}$. 
The first milestone in the survey is the famous decision in the Blanco case, ${ }^{19}$ decided by the Tribunal des conflits in I873. Agnes Blanco, a minor, had been seriously injured by a wagon pushed from a government tobacco warehouse into the street by four employees. The father of the minor instituted an action for damages in the civil court against the four employees and against the state. The prefect of the district asserted the existence of a conflict, denying the jurisdiction of the civil court in a matter of responsibility of the state for mistakes of its agents ${ }^{20}$ in connection with a public service. The opinion ${ }^{21}$ of the commissaire du gouvernement (David) pointed out that, up to the time of this conflict, the Conseil d'État, representing the attitude of the administrative, and the Cour de cassation, representing that of the judiciary, had persistently and firmly adhered to contradictory views. The opinion then proceeds to give a minute and excellent analysis of the principal issue at stake and of the applicable doctrines. It had been conceded by the Cour de cassation that ${ }^{22}$ the ordi-

${ }^{10}$ Blanco v. l'Etat, (Feb. 8, 1873 ) D. 1873.3 .20$, S. 1873.2 .153 ; see also subsequent proceeding in Rec. 1874.416 . See Laferrière, Vol. 1, p. 681; Berthélemy, Traité, pp. 25-26, note 2, 1101; Bonnard, Précis, p. 155; Waline, Manuel, p. 45 ff. Cf. Dekeister v. Administration des postes, (C. d'Et.) S. I 862.2.139.

The court was divided on the issue involved and it required the vote of the Minister of Justice to resolve it in favor of the administration. The decision has recently been attacked by $\mathrm{J}$. Luchet in a thesis mentioned in 52 R. D. P. (1 935 ) 385 .

${ }^{30}$ See chap. VIII, infra.

${ }^{21}$ Regardless of their importance, the decisions of the French courts are rendered in an extremely concise form. It is necessary to consult carefully the opinions (conclusions) of the commissaires du gouvernement (government attorneys), which are usually incorporated in the reports of the decisions. These conclusions go into detailed analyses of the principles involved and, in many cases, the courts adopt them although they are by no means bound by them. The commissaires du gouvernement are maîtres des requêtes (see chap. I, Appendix, supra) specially appointed upon recommendation of the vice-president of the Conseil d'Etat. It is for them to defend the viewpoint which appears to them as conforming most accurately to the law in force. Berthélemy, Traité, p. I I 7. These opinions are frequently relied on in subsequent cases and carry a great deal of weight, particularly if the author is a jurist of especial renown.

${ }^{20}$ Under the laws of Dec. 22, 1789 ; Jan. 8, 1790 (Dec. 22, 1789); Aug. 16-24, 1 790, tit. II, art. I 3; and Fructidor 16, year III (Sept. 2, 1 795), embodying the differentiation of the administrative and judicial agencies (supra, p. 13, note 38 ). 
nary civil courts were without jurisdiction over suits against the state in the case of damages resulting from the acts or omissions of administrative agencies. But the court maintained that in the case of damage caused by the mistakes or negligence of the employees of the state the civil courts were the proper forum.

In the Blanco case the plaintiff insisted that the proceeding was governed by article I384 of the Civil Code, regulating the liability of a master for damage caused by his servants, and that consequently the civil courts were competent to take cognizance of the matter. The state, on the other hand, invoked ( $\mathrm{I}$ ) the doctrine of differentiation of agencies, which reserved to the administrative courts complaints against the state involving its responsibility on account of the performance of a public service, and (2) the laws of 1790 and the year III, according to which the administrative jurisdiction alone could "declare the state debtor." The representative of the state did not concede the applicability of the article of the Civil Code relied on by the plaintiff. After reviewing the origin and the development of administrative justice from the time of the Assemble e Constituante, he pointed out that the original interdiction addressed to the judiciary " $d e$ troubler, de quelque manière que ce soit, les opérations des corps administratifs" ${ }^{23}$ was intended in the last analysis to deny to the judicial courts all power to adjudicate claims against the state whenever a public service was involved. Moreover, the commissaire emphasized that this was meant to apply not only where an action tended to cause the annulment, reformation, or interpretation of an administrative act by those courts, but also where the complaint simply called for pecuniary reparation for damages caused by the act. Citing Thouret's report on the law of August I6-24, I 790, and a dictum by the famed jurist, Henrion de Pansey, as authorities on the respective domains of the administrative and judiciary, the

${ }^{2}$ Law of August 16-24, 1790 , tit. II, art. 13. 
commissaire concluded that the state, as puissance publique charged with carrying on the various services administratifs, could not be subject to the jurisdiction of the ordinary courts. He conceded, however, that wherever the state acts as a private person, as owner of property or as party to a contract, it is amenable to those courts. This rule, he insisted, applied in all cases in which a demand was made upon the state on account of torts committed by its agents in the performance of a public service. He said: ${ }^{24}$

"For the state cannot-in justice or reason-be likened to private persons in respect to liability for acts done by its agents. The part played by the state in carrying out the public services is not voluntary but obligatory; these duties have been imposed upon it not for a private purpose but in the interest of all. We must also consider . . . the enormous number of agents of all sorts which the extent of these services necessitates; as well as the manner of their appointment and advancement. The latter are often determined by general laws or regulations, rather than left to the free choice of each agency. . . . Consequently, the responsibility of the state for the mistakes of these employees cannot be taken to be general or absolute; it must vary so as to be in harmony with the laws and regulations governing each service, and with the individual requirements or nature of the employment. The judicial courts are inherently ill suited to give due consideration to these factors. . . . Their appraisal naturally belongs to the administrative courts, which are in a much better position to interpret administrative laws and regulations, to evaluate the requirements of each service, and finally to reconcile the essential interest of the state with private rights, this reconciliation being the foremost mission of the administrative courts."

After some elaboration of the various points, the commissaire finally emphasized the irrelevance of the fact that the employees involved were ordinary laborers, and concluded: ${ }^{25}$

${ }^{84}$ D. $1873 \cdot 3.20$ at $21: 3$.

25 Ibid. at 2 I-22. 
"What is certain is that the acts complained of are directly connected with an administrative public service, a circumstance which is the very foundation upon which the demand against the state rests. This is all that is necessary to bring the complaint within the general rule that demands upon the state growing out of a public service belong to the jurisdiction of the administrative courts; a rule which is but the application in practice of the doctrine of the separation of powers."

The decision of the Tribunal des conflits affirming the jurisdiction of the administrative courts emphasized especially that the responsibility of the state in circumstances such as those before it "is neither general nor absolute," but "is subject to special rules varying with the requirements of the different services and with the necessities of reconciling the interests of the state with private rights." ${ }^{26}$ The Tribunal held that these matters can be passed upon only by the administrative courts.

2. Extension and Modification of the Rule of the Blanco Case

The principle established in the Blanco case was applied only to actions against the state. Strangely enough, ${ }^{27}$ the civil courts were left to take cognizance of similar actions against districts (départements) and municipalities. This condition persisted unchanged until I 903. In that year the Conseil d'État, and in I 908 and I 909 the Tribunal des conflits, in decisions which are frequently quoted, extended the rule so as to give it general application. In the Terrier case ${ }^{28}$ the Conseil d'État in a somewhat inconclusive manner held itself competent to pass on the liability of a département.

${ }^{26}$ Ibid. at $22: 1$.

${ }^{27}$ See the historical review by the government attorney in the Feutry case, infra, note 29.

${ }^{28}$ Terrier v. Département de Saône-et-Loire, (C. d'Et. 1 903 ) D. 1 904.3 .65$. See Berthélemy, Traité, pp. 26, 1102 ; Hauriou, Précis, 1 oth ed., p. 464, 1 2th ed., p. 459; Bonnard, Précis, p. I 55 ; Waline, Manuel, p. 46. 
The logical extension of the principle to all the political subdivisions of the state was, however, definitely brought about by the decision of the Tribunal des conflits in the Feutry case. $^{29}$ This was an action for damages against a département prosecuted in the civil courts on account of the destruction of private property through fire caused by a lunatic who had escaped from an asylum. The decision in this case is particularly interesting because of the accompanying opinion of another outstanding authority, G. Teissier, who acted as commissaire du gouvernement. ${ }^{30}$ The opinion reviews in an illuminating and instructive manner the doctrinal developments and the adjudications of the three highest courts, which culminated in the firm entrenchment of the rule that the jurisdiction of the administrative courts is exclusive in all actions against the state or its political subdivisions on account of injuries resulting from the functioning of the public services. The rule can be stated more precisely thus: (I) Regardless of the nature of the act causing the damage, if action is brought against the state, a département, colony or municipality, i. e., against a body politic representing the puissance publique, the judicial courts have no power to determine either the fact or the extent of injury; (2) if, on the other hand, action is brought against an individual officer or agent, a distinction must be made between "administrative errors" and "personal errors." ${ }^{31}$ Administrative mistakes concern-

${ }^{20}$ Feutry v. Département de l'Oise, S. 1 908.3.97. See Berthélemy, Traité, pp. 26, 11 02; Hauriou, Précis, 1 oth ed., pp. 41, 465, 1 2th ed., pp. 460, 1065; Bonnard, Précis, p. 155; Waline, Manuel, p. 49.

${ }^{30} \mathrm{~T}$ he report of the decision is also accompanied by an important note by Hauriou, S. 1908.3.97. Cf. the collection of the numerous notes of this author in Hauriou, La Jurisprudence administrative de 1892 à 1929 (1929), Vol. I, p. 573 at 584 .

${ }^{81}$ Fautes de service and fautes personnelles, see chap. VIII, infra; Laferrière, Vol. 1, p. 646 ff.; Ducrocq, Vol. 3, p. $330 \mathrm{ff.;}$ Aucoc, Conférences sur l'administration et le droit administratif, 3d ed. ( 1885), Vol. 1, p. 758 ff.; Teissier, La responsabilité de la puissance publique (1 906), passim; Hauriou, Précis, roth ed., p. 363 ff.; Berthélemy, Traité, p. 82 ff.; Appleton, p. 232 ff., Supp., p. 33 ff.; Bonnard, Précis, pp. 92, 99 ff.; Waline, Manuel, p. $376 \mathrm{ff}$. 
ing the functioning of public services are subject neither to the canons of the civil law nor to the scrutiny of the civil courts. Personal mistakes, however, are deemed to deprive the act in question of its administrative character altogether, thereby eliminating the very foundation for administrative jurisdiction.

In three contemporary cases, one of which ${ }^{32}$ was decided shortly before and $\mathrm{two}^{\mathbf{3 3}}$ within three months after the Feutry decision, the Tribunal des conflits was confronted with similar jurisdictional problems. Hauriou ${ }^{34}$ extracted from the holding in the Feutry case and the three other cases the following principles: If a public service is involved (I) the jurisdiction belongs to the ordinary courts provided the damage is due to a faute personnelle "separable from the exercise of official functions" $;^{35}(2)$ the jurisdiction is administrative $^{36}$ in case of faute de service; (3) in the event of damage attributable neither to official nor to unofficial conduct of administrative agents, but to a public works itself, the administrative jurisdiction ${ }^{37}$ must be invoked.

The tendency to broaden the administrative jurisdiction, reflected in the foregoing precedents, was critically commented upon by at least one of the experts in the field. Professor Berthélemy ${ }^{38}$ at the time pointed out interestingly that the Conseil d'Etat, in exercising jurisdiction over controversies arising from fautes de service, did not administer judicial relief; no violation of a right being involved, favor-

${ }^{22}$ Gillet v. Panier et l'Etat, S. 1 909.3.49.

${ }^{33}$ De Fonscolombe v. Ville de Marseille, and Joullié v. Assoc. Syndic. du Canal, both also reported in S. 1909.3.49.

${ }^{34}$ See S. 1908.3.97, Jurisprudence, Vol. I, p. 588 ff.; 25 R. D. P. (1908) $691-92$.

${ }^{35}$ Infra, chap. VIII.

${ }^{36}$ Conseil d'Etat.

${ }^{\text {or }}$ Conseil de préfecture.

${ }^{38}$ Traité de droit administratif, sth ed., p. 891, disapprovingly referred to by Jèze in a note on the Feutry decision in $25 R$. D. P. (1908) 266 at $269 \mathrm{ff}$. 
able action by the Conseil was essentially executive in that it granted voluntary indemnity. This construction is not altogether surprising if one considers the history of the Conseil d'État as an administrative body, and also the administrative aspects of judicial annulment, by the Conseil, of administrative acts. ${ }^{39}$ It is arguable that in matters of state responsibility, arising from public service operations, the administrative department cannot be relied upon to be sufficiently impartial in granting indemnity. Furthermore, it is true that to require all private claims, even those against municipalities, to come before a single court, such as the Conseil d'État, constitutes a hardship upon claimants.

It should be remembered, however, that the one-time movement which favored the ordinary courts for the adjudication of such claims, even though based on the ground that the claims arose from actes de gestion, was intimately connected with the absence of independent administrative courts. As these courts were developed and improved, and as confidence in their impartiality and especial familiarity with administrative law problems grew, the general sentiment became actually reversed. ${ }^{40}$ Jèze ${ }^{41}$ has gone so far as to remark that today, "one must take into account that in France the ordinary courts have little prestige and are afraid of displeasing the administrative." If this is true, it must seem natural that claimants prefer to come before the administrative courts, which, although distant, have no hesitations in granting indemnity, "rather than to resort to the ordinary courts, [which are] nearer, but traditionally known to be reluctant to condemn the administrative, fearing to be accused of obstructing the acts of its agents." ${ }^{42}$ Viewed in this light, the

\footnotetext{
${ }^{30}$ Recourse for excess of power, supra, pp. $31-33$.

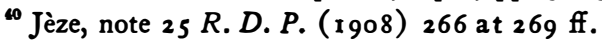

42 Ibid., p. 272 ; cf. Waline, Manuel, p. 300.

2 Jèze, p. 272.
} 
differentiation of agencies would seem to have succeeded far beyond securing the administrative against judicial interference, by enveloping the judiciary in a more or less transparent veil of subservience, thereby enhancing the popularity of, and confidence in, administrative justice. ${ }^{43}$ However, statements to this effect are extreme and should be received with caution. It can be demonstrated ${ }^{44}$ and it is highly important that in other respects the contrary is true.

\section{The Public Service Criterion Applied to Contracts}

\section{(a) The Thérond Case}

The concessions to the administrative jurisdiction in controversies arising from public service, beginning with actions against the state involving its liability for injury or damages to private persons, and extending gradually to the similar liabilities of the départements and municipalities, culminated in the decision of the Conseil d'Etat in the case of Therond v. Ville de Montpellier. ${ }^{45}$ Although the public service criterion had long since become an important limitation upon the jurisdiction of the ordinary courts over actes de gestion, it had not as yet been applied to litigation involving contracts. Despite the countless instances in which the agents of the government, for the accomplishment of various administrative purposes, must needs resort to the contractual form of action, the jurisdiction of the ordinary courts over all contract disputes with the administrative agencies remained intact. ${ }^{46}$ Only where the contracting agency clearly acted as puissance publique, and where the contractual aspect of its action was purely incidental, did the administrative ju-

\footnotetext{
${ }^{2}$ Cf. Appleton, p. 9 ff., Supp., pp. 7-8.

4 Chaps. IX and $X$, infra.

${ }^{45} \mathrm{~S}$. 1911.3 .17 , decided in 1910.

so Jèze, comment on the Thérond decision, $27 R, D, P$. (1 gro) 249.
} 
risdiction prevail. This rule was subject only to express statutory exceptions. ${ }^{47}$

In the Therrond case, for the first time, extended but logical use was made of the public service concept for the purpose of determining jurisdiction in contract cases. The city of Montpellier had entered into a contract with Thérond for the capture of stray dogs and the removal of dead animals in the city. A dispute arose over the agreement and action was brought in the Conseil d'Etat. ${ }^{48}$ Discharging the duty of determining its own jurisdiction, the Conseil found that the contract was intended for the performance of a public service, i. e., the protection of public health and safety, and that therefore the case was properly before it. With this important step in the interpretation of the differentiation of agencies, ${ }^{49}$ the Therond decision seemed to terminate the development which was marked by the earlier cases discussed in this chapter.

Retracing the entire development, we observe that at the initial stage all acts of the administrative were indiscriminately withdrawn from the cognizance of the ordinary courts. Later, acts of management were restored to the jurisdiction of these courts, and ultimately public service, i. e., performance of strictly governmental functions, was accepted as a unit of action and a basis of jurisdiction. ${ }^{50}$ The result of the holding in the Therond case, subjecting all contracts made in connection with governmental functions to administrative jurisdiction, was to make the special technical fitness of the administrative courts available for the adjudication of all disputes where it might be desirable.

${ }^{47}$ Laferrière, Vol. 1, p. 587 ff.; Berthélemy, Traité, p. 11 1.

48 The contract granting Thérond a monopoly was held ultra vires and consequently rescission and restitution were awarded to Thérond.

${ }^{\infty} \mathrm{Cf}$. Hauriou's note accompanying the Thérond decision-S. 1911.3 .17 and Jurisprudence, Vol. 3, pp. 679 at 685 ff. See also his Précis, roth ed., p. 465, 12 th ed., p. 460.

${ }^{50}$ See the comment by Jèze in $27 R . D . P$. (1910) 249. 
However, it soon became obvious that the latest extension of the administrative jurisdiction involved a noticeable disadvantage in engaging the administrative court machinery with countless trivial matters, which unnecessarily taxed their limited facilities. Quite naturally, therefore, the evolutionary process which had its beginning in the Blanco decision did not terminate abruptly with the Therrond case. It is noteworthy that only a few months after the Conseil d'Etat had asserted its jurisdiction over the contractual relation in that case, on the ground that the contract pertained to public service, the Tribunal des conflits, in Compagnie d'assurances "le Soleil" v. l'Etat, ${ }^{\text {51 }}$ signified its adherence to the older doctrine, expounded by Laferrière, ${ }^{52}$ according to which jurisdiction over controversies founded on contract belongs to the civil courts "even if the object of the contract is the functioning of a public service."

\section{(b) Qualification of the Rule of the Thérond Case}

The rule announced in the Therrond decision, which seems to have been ignored by the Tribunal des conflits, was modified by the Conseil d'État itself when, two years later, it declined to take jurisdiction in the case of Société des granits $v$. Ville de Lille. ${ }^{54}$ The plaintiff corporation there sought to recover a sum of money under a contract for the furnishing

$\sigma$ Rec. 1910.446.

Vol. I, pp. 587-88, 595 .

"The contract in the "Le Soleil" case was not one of a private person with the government, but one between a city and the military for the temporary occupation by troops of a city-owned building. A fire occurred and the insurer of the premises, as subrogee of the city, filed suit against the state in the Court of Appeals of Paris.

In this case the commissaire du gouvernement, whose conclusions the Tribunal adopted, was the attorney general, i. e., a member of the judiciary. Jèze, in a critical comment, $27 R$. D.P. (1910) 468, suggests that had the commissaire brought the Thérond decision to the attention of the Tribunal, the latter would have followed the principle announced by the Conseil d'Etat.

${ }^{4}$ D. 1916.3 .35 ; S. 1917.3.15. See Berthélemy, Traité, p. 1103; Bonsard, Précis, p. 156; Waline, Manuel, p. 48. Cf. Duguit, Traité, Vol. 3, P. 39 ff. 
of paving material to the defendant city ${ }^{55}$ Leon Blum, ${ }^{56}$ acting as commissaire du gouvernement, injected into his opinion a new distinction. He insisted that while precedent had overcome the former interpretation of the principle of the differentiation of agencies, it was not the purpose of the new doctrine to withdraw indiscriminately from judicial cognizance all claims sounding in contract to which an administrative agency is a party. He argued that even though the object of the contract is related to a public service, ${ }^{57}$ the question of jurisdiction should be determined by establishing whether the contract is an "administrative contract" or an "ordinary common-law contract." The government attorney said that a contract is administrative if it is so in form and context; in other words, the contract must be one which can be made only by a personne publique, and which creates a definite, continuing relationship between the private party and the municipal corporation or the public. Conversely, according to $\mathbf{M}$. Blum's definition, the contract is a private one whenever these conditions do not obtain, and when the contractual relationship does not persist, as in the case of an executed sale of paving material. He concluded that the administrative in this case had contracted as a private party and any subsequent litigation, therefore, was for the determination of the ordinary courts. The Conseil d'État adopted this opinion and the resulting solution.

The holding in the last case seems to be tantamount to a return to the old distinction between "authoritative acts"

${ }^{56}$ The case concerns, and is of importance in connection with, similar contracts of départements and municipalities only. As to the state, the administrative jurisdiction had been fixed at an early date by statute (Decree of June I I, 1806, art. 13) in regard to contracts coming within the category of supply contracts (marchés de fournitures). Hauriou, Précis, roth ed., p. 792 ff., 12 th ed., p. 953 ff.; Berthélemy, Traité, p. 593.

" Later Premier of France (1936-1937, 1938).

${ }^{57}$ Particularly, as in the instant case, the furnishing of material for the paring of streets. 
and "acts of management" in so far as the contracts of administrative agencies are concerned. Applied to contracts, the doctrine of public service, carefully developed as an expedient mode of determining the bounds of administrative jurisdiction, failed to show the supposed qualities of an opensesame. ${ }^{58}$ The solution adopted in the Sociéte des granits case is in keeping with the generally pragmatic rather than strictly doctrinal tendencies of the Conseil d'Etat. The criteria proposed by Commissaire du Gouvernement Blum for determining jurisdiction yield a rule sufficiently elastic to permit the sifting of the mass of contractual disputes and to guard the Conseil d'Etat against having to pass on countless unimportant matters. ${ }^{59}$ Nevertheless, it is equally true that the rule complicates the determination of jurisdiction and precludes the latter from being predicted with much accuracy, thus working hardship upon private litigants. Just when a contract is or is not administrative is by no means easily determined under all circumstances. It is evident that both the doctrine of the Therrond case and the more flexible rule of the Société des granits decision are apt to produce undesirable results. ${ }^{60}$

This situation presents the problem of a difficult choice between the overcrowded docket of a high court and the uncertainty attending the selection of the competent forum by private parties dependent upon judicial interpretation of their contractual rights: Under circumstances such as those which prevail, it would seem that the interests of litigants at large would be best served by maintaining the quality of the

${ }^{8}$ The Société des granits decision was cited and followed by the Tribunal des conflits in Boyer et Jullian v. l'Etat, (1930) D. 1931.3.33; 48 R. D. P. (1931) 807.

${ }^{50}$ This view has been aptly illustrated by Berthélemy (Traité, p. 1104), who refers to the possibility of "having to settle a bill for the purchase of a bottle of ink or a box of pens because they were purchased to be used by a public school." See also ibid., p. 6 I 5 (and roth ed., p. 525, note 3 ).

"o Jèze, in a comment in 31 R. D.P. (1914) 145, attacks the latter decision on the score that "the organization of the courts is designed for the convenience of the parties and not for that of the judges or lawyers." Ibid., p. I 52. 
court's work by reducing the class of cases cognizable by the Conseil d'État, so long as additional court machinery is not available.

In 1934, by a decret-loi, ${ }^{61}$ original jurisdiction was in fact conferred upon the Conseils de préfecture in a number of matters which had been cognizable in the Conseil d'Etat. The statute applies to four specified types of cases, including contract and damage claims other than those against the central government. ${ }^{62}$ However, this measure is largely ineffectual for the purpose of unburdening the Conseil d'Etat. It merely leads to a changed system of appeals, since the Conseil d'Etat is still open for the review of these same controversies.

However, the ultimate significance of the decision in the Sociéte des granits case lies in that it questions the adequacy of public service as the only criterion by which to determine jurisdiction over contracts, and that it stresses the necessity for making other distinctions. In this connection it is important to note the statutory solution in case of contracts made by the central government for supplying its public services. ${ }^{63}$ The statute, which expressly classifies these contracts as "administrative contracts" and subjects them to the jurisdiction of the Conseil d'Etat, antedates by many decades the recognition of public service as the primary factor in the determination of jurisdiction. It may well be assumed that the statute is declaratory of a principle, and that the making of contracts of this type by the state was deemed an "act of authority," in view of the importance of the marchés de fournitures. $^{64}$

${ }^{81}$ Decret-loi of May 5, 1934.

see the critique of the statute in 51 R. D.P. (1934) 318.

"Marchés de fournitures, supra, note 55.

'See Berthélemy, Traité, pp. 593-94; Hauriou, Précis, I oth ed., p. 793, I 2 th ed., p. 954. There is an apparent inconsistency in Hauriou's relating this instance of administrative jurisdiction to the public service concept. roth ed., p. 876 , note I (a). 
The rule of jurisdiction concerning contracts was further qualified in I 928 , when the Tribunal des conflits, deciding the case of Templier v. Commune de Sempigny, ${ }^{65}$ adopted a new distinction which was not in any way related to the public service notion. Radically departing from the former line of approach, the Templier decision makes the administrative jurisdiction dependent upon express clauses appearing in the respective contracts. This not only permits a choice of jurisdiction in advance of litigation, but it forces administrative agencies to proceed by way of contrat administratif rather than by contrat judiciare, if they desire the contract to be subject to interpretation in the administrative courts exclusively. The holding seems to signify the abandonment of the service public criterion in favor of puissance publique as the primary basis of the administrative jurisdiction in the matter of contract. ${ }^{68}$ This indeed had already been suggested by Commissaire Blum in the Société des granits case. ${ }^{67}$

\section{Later Developments-Commercial and Noncommercial Public Service}

The most recent developments concerning the jurisdiction of the administrative courts had their basis in the holding of

${ }^{65}$ S. 1928.3 .129$.

${ }^{60}$ See the note by Hauriou accompanying the decision, summarized in 46 R. D. P. (1929) 1 54. Hauriou, Précis, 1 2th ed., pp. 954-55, argues: "Consequently the administration is enabled to determine the jurisdiction at will by inserting into, or omitting from, the contract stipulations manifesting the exercise of sovereign power." Cf. Hauriou's note accompanying the earlier decision of the Conseil d'Etat in Commune de Monségur v. Lalanne (S. 1 921 1.3.49) where he takes issue with Jèze, who insists that service public is the basic concept underlying all administrative law theory.

${ }^{\circ 7}$ As to "administrative contracts," see Jèze, Les contrats administratifs (1927), and by the same author "Théorie générale des contrats de l'administration," 47 R. D. P. (1930), 82, 260, 426, 680; 48 R. D. P. (1931) 70, 245, 496, 681; 49 R. D.P. (1932) 244, 581; 50 R. D.P. (1933) 51, 371, 573; 51 R.D.P. (1934) 70, 570; 52 R.D.P. (1935) 5, 237, 482, 712; 53 R. D. P. (1936) 4I, 239 . 
the Tribunal des conflits in the Feutry case. ${ }^{68}$ The immediate effect of the decision was to give general validity to the concept of public service, initiated by the Blanco case, as a limitation upon administrative competence in respect to claims for damages against the state and its political subdivisions. Indirectly this resulted in a corresponding redistribution of jurisdiction over contracts, although the ultimate solution concerning the latter is marked by a reversion to the older distinction of authoritative and nonauthoritative acts. It may be granted that the chronological sequence of events has been largely coincidental. Nevertheless, it was not until preoccupation with jurisdiction over contracts subsided, following the Templier decision, that interest became focused again upon the jurisdictional problems arising from administrative torts and quasi-torts. Conflicting considerations gave impetus to varying solutions.

In I 934 the Conseil d'État, in the matter of Mabille v. Ville de Paris, ${ }^{69}$ declared the juridiction administrative, rather than the ordinary courts, competent to pass on the liability of the municipality for injuries and damages resulting from the collision of a taxi with a truck operated by the streetcleaning department, a public service. The particular significance of the decision lies in the fact that it seemed to "overrule" a decision of the Tribunal des conflits rendered a few months earlier in the Mélinette case. ${ }^{70}$ In that case the Tribunal was divided and, contrary to the opinion of the commissaire du gouvernement, ${ }^{71}$ in the face of almost identical facts, declared the judicial courts competent to hold the city of Paris liable in damages. It must be noted, however, that the plaintiff, Mme. Mélinette, within her statutory rights, had

${ }^{88}$ S. r 908.3 .97 , supra, note 29.

${ }^{\oplus}$ Decided February 9, 1934. D. 1934.3.9; see the note in 51 R. D. $P$. (1934) 130.

${ }^{70}$ (July II, I933) S. 1933.3.97; note by Jèze, 50 R. D.P. (1933) 426.

${ }^{n} \mathrm{Cf}$. the accompanying note by Alibert [analyzed 5 I R. D.P. (1934) 140]. 
simultaneously instituted an action ex delicto against the driver of the city truck and an action against the city. The decision of the Tribunal des conflits therefore produced the desirable result that the same court could hear both actions, instead of subjecting the plaintiff to the inconvenience of having to seek relief before different tribunals. In order to avoid the implicit deviation from the principle of differentiated agencies as previously interpreted, ${ }^{72}$ the court resorted to the expedient of distinguishing industrial or commercial public services ${ }^{73}$ from other public services. ${ }^{74}$ Declaring the service involved to be of the first type, i. e., "conducted by methods similar to those which a private industrial enterprise would employ," ${ }^{\prime 75}$ the court decided the Mélinette conflict in favor of the ordinary jurisdiction. ${ }^{76}$

A better view of the jurisdictional situation subsequent to the Mélinette decision may be gained from the resolution of the conflict ${ }^{77}$ in Verbanck v. Le Béguec, ${ }^{78}$ reported conjointly with the Mabille case. Apparently the alarm caused by the Mélinette decision was not justified. In the first place, the contrary holding by the Conseil d'État in the Mabille case

72 Jèze, 50 R. D.P. at 427.

${ }^{73}$ Bonnard, Précis, pp. 156, 169; Waline, Manuel, pp. 50, 587.

${ }^{74}$ A similar distinction seems to have been rejected by the opinion in the Blanco case.

${ }^{\pi 5}$ See note by Waline, D. 1934.3.9; 51 R. D. P. (1934) 458. An analogy may be found in the American state cases holding that a municipality is subject to suit for damages in the civil courts if the performance of a governmental function is coupled with an incidental profit-Foss v. City of Lansing, (1927) 237 Mich. 633-or if the public service is partly of a commercial characterHaley v. City of Boston, (1906) I 91 Mass. 291 at 293.

${ }^{70}$ This sub-classification of public services furnished the basis for the criticism which the decision provoked. It was severely attacked in the conclusions of the commissaire du gouvernement upon which the Conseil d'Etat subsequently decided the Mabille case, supra, note 69.

${ }^{77}$ The accidental death which was the cause of action came about through the negligent operation on a highway of a truck of the state highway department.

${ }^{78}$ D. 1934.3 .9$, S. 1934.3 .33 , 50 R. D. P. (1933) 620; see particularly the accompanying note in Dalloz by Professor Waline, analyzed 5 I R. D. P. (1934) 458, and that by Alibert in Sirey, analyzed 51 R. D. P. (1934) 457 . 
seemed to indicate that the Tribunal des conflits had not intended to establish a new principle; for, ordinarily, the Conseil d'État respects rather than disregards the holdings of the Tribunal. In the second place, it is possible to reconcile the two decisions because of a difference in the facts. In the earlier matter (Mélinette) the driver had left the truck unguarded in the street, while in the second case (Mabille) at the time of the accident the employee was driving and was in control of the vehicle. It was, therefore, possible to consider the injury in the Mélinette case as having resulted not directly, but in a manner independent from the operation of a public works. In the Verbanck case, where the truck was again in the control of the negligent driver, the opinion suggested further that "it would scarcely occur to anyone to assimilate the bridge and highway department to a commercial enterprise." The Tribunal upholding the administrative jurisdiction borrowed language from the Blanco decision. One cannot read the comments elicited by the Mabille and Verbanck cases without the impression that considerable relief was experienced over the apparent return to the established principle of administrative competence in all matters pertaining to public service. ${ }^{79}$

Nevertheless, the spectre of the vaguely defined distinction between industrial or commercial and other public services continued to thwart the ready determination of jurisdiction. ${ }^{80}$ The distinction actually was not a new one. Originally used in connection with controversies between governmental services and customers, it came to be progressively applied first to relations between these services and their personnel and

${ }^{70}$ See the note by Alibert, S. 1934.3.33, 51 R. D. P. (1934) 457, pointing out the return in the Verbanck case to the principles first established by the Blanco decision and also characterizing the Mabille decision as "a return to sound traditions."

${ }^{80} \mathrm{Cf}$. the similar objection advanced by Jèze concerning the differentiation of contracts affecting a public service in Société des granits, supra, note 60. 
then to relations between the services and other administrative agencies. Finally, the distinction caused concern when the Mélinette decision extended its application to controversies between a public service and a third party. ${ }^{81}$ It was deemed desirable therefore to limit the term "industrial or commercial public service" to those services whose performance, according to their legislative design, ${ }^{82}$ conforms to the methods which would be employed if they were rendered to the public by private enterprise. Thus indemnity cases, very similar to contractual disputes, if occasioned by the public services, must be litigated in the ordinary courts whenever the manner in which the administrative conducts its business gives rise only to questions of private law. ${ }^{83}$

The general tendency, however, is to favor the administrative courts. This is evidenced by two recent decisions of the Conseil d'Etat holding, for the first time, that controversies between two independent contractors engaged upon the same public works, fall within the administrative jurisdiction of the Conseils de prefecture. The reason given was that even though damage to an independent contractor was directly caused by another contractor, it must nevertheless be deemed to have resulted from the execution of the public works upon which both were employed, i. e., from a public service. $^{84}$

${ }^{81}$ See the note by Waline in D. 1934.3.9, 51 R. D. P. (1934) 459; Bonnard, Précis, pp. 1 56-57. In an earlier case (Colonie de la Côte d'Ivoire, D. 1921.3 .1 ) the commissaire du gouvernement proposed that the differentiation of agencies required that the administrative courts be competent only in regard to "essentially administrative functions" and not to acts which are outside these "natural functions," even though they are in the public interest.

${ }^{82}$ A typical instance is the law of July 15, 1845, art. 22, concerning the operation of railroads. See the later decision of the Conseil d'Etat of July 26, 1929 (Commune de Chailly-en-Bière, D. 1930.3.1, D. H. 1929.512; $47 R$. D. P. ( 1930 ) 773), particularly the accompanying note (2) in Dalloz by Professor Appleton as to restricting the distinction in this sense.

${ }^{83}$ See Waline's note, D. 1934.3.9; Waline, Manuel, p. 50.

84 Matter of Chauveau and Matter of Société des Eaux de Deauville, (Dec. 16, 1932) D. 1934.3.1, 50 R. D.P. (1933) 246, 51 R. D. P. (1934) 314. 


\section{Chapter V}

\section{A Comparison of Administrative Review and Judicial Review}

HE main object of the jurisdictional concepts whose formulation accompanied the development of French

1 administrative law was to permit, as far as possible, a distribution of jurisdiction which would be not only logical, but workable and readily ascertained. Before the Conseil d'État had become well organized as a court of justice, administrative adjudication was limited to actes de puissance publique, i. e., to acts which, because of their authoritative nature, clearly could not be interfered with by the ordinary courts without violating the differentiation of agencies. As the administrative courts gained prestige, and as the modern demands upon the administration increased, the classic distinction between authoritative acts and simple acts of management lost some of its usefulness. It had to be realized that although some of the administrative business often paralleled and closely resembled private business, these acts of administrative agencies in many instances were inseparably connected with and indispensable to the performance of essential governmental functions. If the ordinary courts were permitted to take cognizance of such acts, they might, without difficulty, obstruct administrative action in the sense of the constitutional prohibition. Thus service publique came to supplement puissance publique. Both the narrower sphere of administrative jurisdiction over actes de puissance public and the larger area covered by all acts pertaining to public service were susceptible of fairly clear definition. But watchfulness on the part of both courts and legal critics has prevented the rigor mortis of a fixed line of demarcation. Conflicting considerations 
forced the maintenance of flexibility. In response, subclassifications, such as the distinction of administrative from ordinary contracts and the distinction of commercial or industrial services from all other public services, emerged.

Viewed in the light of the separation of powers, the relationship between administrative and judiciary in France is unique. After the establishment of administrative courts, there has been no problem of judicial review in the Anglo-American sense. Review and relief administered by courts are guaranteed, and the sole question which arises is concerned with the allocation of jurisdiction to two independent sets of courts.

On the other hand, the actual distribution of jurisdiction between the administrative and the ordinary courts in France reveals ideas and preoccupations quite familiar to the American lawyer. So far as the administrative courts are concerned today, any tendency to enlarge ${ }^{1}$ their competence usually expresses the desire of making, or rather keeping, the expertness and special training of a carefully selected personnel ${ }^{2}$ available in all matters which are essentially and intrinsically administrative. The French system offers few obstacles in this respect, and it has been relatively simple to formulate concepts which have satisfied this general trend.

The corresponding situation which presents itself in this country seems on the surface to be radically different. In truth, however, this is only a first impression caused by the basic constitutional arrangement. As has been pointed out earlier, ${ }^{3}$ one of the immediate objects of the adoption of the separation of powers was to create a strong judiciary. It was

"Admittedly, the word "enlarge" is not entirely accurate in this connection. The jurisdiction of the French administrative courts, with their inherent power over all administrative acts, is theoretically not susceptible of enlargement. However, the term "administrative" has required reinterpretation from time to time with corresponding shrinkages or enlargements in the actual scope of administrative jurisdiction.

Supra, chap. I, Appendix.

- Chap. II, p. 22. 
inevitable that judicial power should be defined broadly since interference with either legislative or administrative action, whenever necessary under the Constitution, was intended. In order, therefore, to elicit the facts which are pertinent to the present comparison, the question must be asked, "What have the courts of the United States done?", while the inquiry as to the French system was, "What may the ordinary courts do?" \&

\section{Separation of Powers}

Interpreting the constitutional separation of powers, the United States Supreme Court at an early date, in connection with Hayburn's Case, ${ }^{4}$ rejected a congressional assignment to the federal judiciary of "duties" not "properly judicial." In a consistent line of subsequent decisions the court perpetuated the rule that the constitutional courts cannot exercise administrative functions. ${ }^{6}$ Thus in the recent case of Federal Radio Commission v. General Electric Co. ${ }^{7}$ the Supreme Court held that $\S 16$ of the Radio Act of $1927^{8}$ conferred upon the Court of Appeals of the District of Columbia "purely administrative" powers in directing it to "hear, review and

( (1792) 2 Dall. (2 U. S.) 409.

- The act of March 23, 1 792, I Stat. L. 243, imposed upon the federal circuit courts the duty of passing upon petitions of persons who wished to be put on the pension list of the United States. The determinations of the courts were made subject to revision by Congress and by executive officers. The judges of the circuit courts for Pennsylvania, New York and North Carolina had expressed opinions against the validity of such legislation. See Hayburn's Case, (1792) 2 Dall. (2 U.S.) 409 at 4 ro, note.

- Federal Radio Commission v. General Electric Co., (1930) 28 I U. S. 464 [cf. Federal Radio Commission v. Nelson Bros. Bond \& Mortgage Co., (1933) 289 U. S. 266 at 276-277]; Postum Cereal Co. v. California Fig Nut Co., (1927) 272 U. S. 693 ; Ex parte Bakelite Corp., (1929) 279 U. S. 438 at 449; Keller v. Potomac Electric Power Co., (1923) 26I U. S. 428 at 444; see the dissenting opinion in Old Colony Trust Co. v. Commissioner of Internal Revenue, (1929) 279 U. S. 7 16. Cf. Borreson v. Department of Public Welfare, (1938) 368 Ill. 425 , noted 37 Mich. L. Rev. (1 939 ) 639.

${ }^{7}$ (1930) 281 U. S. 464.

44 Stat. L. 1169 , providing for the granting of and renewal of licenses to radio stations (italics added in quotation). 
determine" appeals from the Federal Radio Commission, and to "alter, or revise the decisions appealed from and to enter such judgment as to it may seem just." Consequently, the Supreme Court could not review the judgments of the court of appeals without assuming to perform an "essentially administrative function." The Radio Act was then amended ${ }^{9}$ by limiting the review powers of the court of appeals to "questions of law." Passing on the amended statute, ${ }^{10}$ the Supreme Court decided that the "limitation manifestly demands judicial, as - distinguished from administrative, review." "11 Hence the decision of the court of appeals had become susceptible of revision by the highest constitutional court.

This development is of interest for the present purpose. For to the extent of the established doctrine, the constitutional courts cannot, no more than can the judicial courts of France, participate in determining purely administrative questions, ${ }^{12}$ although the American courts by the same constitutional principle may exercise a large amount of control over the acts by which administrative policies are carried into effect. On the other hand, it is necessary to take into account the type

- (1930) 46 Stat. L. 844; now superseded by the Communications Act of 1 934, 48 Stat. L. 1 064, 47 U. S. C. (1 934), § 151 et seq.

${ }^{10}$ Federal Radio Commission v. Nelson Bros. Bond \& Mortgage Co., (1 933 ) 289 U.S. 266 at 276.

${ }^{11}$ So far as the Court of Appeals of the District of Columbia is concerned, Congress may confer administrative (as well as legislative) functions upon the court, since it is a legislative and not a constitutional (Art. III) court. See Katz, "Federal Legislative Courts," 43 Harv. L. Rev. (1930) 894.

The subsequent action of the Supreme Court, holding that the courts of the District of Columbia have a dual status as legislative (Art. I) and constitutional (Art. III) courts did not deprive those courts of the power to exercise other than judicial functions. O'Donoghue v. United States, (1933) 289 U. S. 516 at 550-551. But compare the dissenting opinion of Chief Justice Hughes, ibid. at 551 .

13 The situation under the several state constitutions is not so clear. In many instances state courts exercise statutory review functions which would be condemned under the doctrine of Federal Radio Commission v. General Electric Co., supra, note 7. But compare the extreme case of Borreson v. Department of Public Welfare, supra, note 6, where the Illinois Supreme Court invalidated an assignment of "executive functions" to the judiciary. 
of acts which under the rule have been held to involve only non-judicial questions. Past interpretations of the term "administrative" reveal considerable judicial temperament. There has been much emphasis upon the relative directness or indirectness of affectation of vested rights as a criterion. Other important considerations for holding acts administrative, and therefore not subject to judicial revision, have thereby become obscured. This has been particularly evident in the socalled "negative order" doctrine, which has recently received disapproving analysis by Mr. Justice Frankfurter in the case of Rochester Telephone Corporation v. United States. ${ }^{13}$ The doctrine, whose origin is associated with Procter E Gamble Co. v. United States, ${ }^{14}$ the Supreme Court's interpretation of the review provisions of the act of Congress creating the Commerce Court, ${ }^{15}$ requires that administrative orders to be reviewable must be affirmative. ${ }^{16}$ One of the chief illustrations of the doctrine discussed in the opinion is the familiar decision in United States v. Los Angeles E S. L. R. Co. ${ }^{17}$ There the final valuation of railroad property was held not to present a justiciable question because the order under the Valuation Act ${ }^{18}$ was made solely for the purpose of information to be incorporated into the records of the Interstate Commerce Com-

19 (1939) 307 U. S. 125. See "A Redefinition of Judicial Review of Administrative Orders," 48 Y'ale L. J. (1939) 1257; see also 38 Mich. L. Rev. (1940) 682.

14 (1912) 225 U. S. 282.

${ }^{15}$ ( 1910 ) 36 Stat. L. 539, later $\$ 207$ of the Judiciary Act of March 3, 191 1, 36 Stat. L. 1087 at 1148 , and as amended now 28 U. S. C. (1934), \$ 4 I $(27,28)$.

${ }^{16}$ Three groups of orders which are not affirmative are distinguished and illustrated: ( 1 ) orders which do not have the effect of forbidding or compelling conduct without further action by the administrative body; (2) orders denying exemption from a statutory command; (3) orders declining to forbid or compel conduct by a third person. Rochester Telephone Corp. v. United States, (1939) 307 U. S. 125 at $129-130$.

${ }^{17}$ (1927) 273 U.S. 299.

${ }^{10}$ Sec. r 9 a of the Act to Regulate Commerce of Feb. 4, I 887, 24 Stat. L. 379, as amended; now 49 U. S. C. (1934), § r 9 a. 
mission. The order was not made with a view to immediate further action, as for the establishment of rates of transportation. Mr. Justice Frankfurter, quoting language from the opinion, ${ }^{19}$ explains the nonreviewability of the order in the Los Angeles case by the absence of a "case or controversy" in the sense of Article III, section 2 of the United States Constitution, as elaborated in the Muskrat case. ${ }^{20}$ It is believed, however, that the clue is furnished by the separation of powers doctrine and the reasoning which connects Hayburn's Case with Federal Radio Commission v. General Electric Co. The valuation function, taken as an example, particularly if wholly disconnected from further action, such as rate-making, is so peculiarly administrative in a technical sense that "judicial abstention"21 seems no more than the realization of a logical division of work. ${ }^{22}$ Thus "the impelling consideration" which Mr. Justice Frankfurter feels actually underlies the decision in the Procter $E$ Gamble case must apply with equal force to the Los Angeles case. The passage quoted by him, ${ }^{23}$ as well

${ }^{10}$ Rochester Telephone Corp. v. United States, (1939) 307 U. S. 125 at 130-1 3 I, quoting from United States v. Los Angeles \& S. L. R. Co., (1927) 273 U. S. 299 at 309-310: "The so-called order here complained of is one which does not command the carrier to do, or to refrain from doing, anything; which does not grant or withhold any authority, privilege or license; which does not extend or abridge any power or facility; which does not subject the carrier to any liability, civil or criminal; which does not change the carrier's existing or future status or condition; which does not determine any right or obligation."

${ }^{20}$ Muskrat v. United States, (I 9 I I ) 2 I 9 U. S. 346.

21307 U. S. 125 at 13 I.

22 In fact, Mr. Justice Frankfurter also classifies Hayburn's Case with the Muskrat case. However, it seems quite clear that the constitutional background of Hayburn's Case is the separation of powers, while that of the Muskrat case is the narrower principle of $\S 2$ of Art. III of the Constitution.

${ }^{23} 307$ U. S. 1 37, note 14, quoting from Procter \& Gamble Co. v. United States, (1912) 225 U. S. 282 at 296-297: “. . . we have learned of no instance where it was held or even seriously asserted, that as to subjects which in their nature were administrative and within the competency of the Commission to decide, there was power in a court, by an exercise of original action, to enforce its conceptions as to the meaning of the act to regulate commerce by dealing directly with the subject irrespective of any prior affirmative command or action by the Interstate Commerce Commission. On the contrary, by a long line of decisions, whereby applications to enforce orders of the Commission were con- 
as other parts of the opinion in the Procter $\mathcal{G}$ Gamble case, clearly recognizes the importance of leaving all purely administrative matters to be dealt with by technical experts. This aspect of nonreviewability has many times been emphasized. ${ }^{24}$

The orders of nonjudicial tribunals, however, much more frequently are not strictly confined to the disposition of technical administrative matters. In many instances they are coupled with the simultaneous creation of rights and duties, and it is at this juncture that, under the American administrative system, they are deemed to lose their constitutional immunity and to fall within the area of reviewability in the courts. Unhampered by any recognized implications of the separation of powers, the courts have only their own discretion to guide them in the circumscription of their review functions. But once an administrative order has been classified as not strictly administrative and therefore reviewable, ${ }^{25}$ it becomes all the more important that the benefits of primary expert administrative determination should be retained. Ac-

sidered and disposed of or where requests to restrain the enforcement of such orders were passed upon, it appears by the reasoning indulged in that it was never considered that there was power in the courts as an original question without previous affirmative action by the Commission to deal with what might be termed in a broad sense the administrative features of the act to regulate commerce by determining as an original question that there had been a compliance or non-compliance with the provisions of the act."

24 "A Redefinition of Judicial Review of Administrative Orders," 48 Yale L. J. (1939) 1257 at 1258; Cooper, "Administrative Justice and the Role of Discretion," 47 Yale L. J. (1938) 577 at 600; Landis, The Administrative Process (1938), p. 142 ff.; Dickinson, Administrative Justice and the Supremacy of the Law (1927), pp. 61, 71-72, 233-235, 254.

${ }^{25}$ Compare the "Classification of Judicial Functions Exercised by Federal Administrative Agencies," attempted by the Special Committee on Administrative Law of the American Bar Association, 61 Rep. A. B. A. (1936) 720 at 745. Observe that licensing is quite commonly thought to be administrative, while the revocation of a license is deemed a judicial act, leaving considerable doubt as to the nature of the renewal of licenses, particularly when renewal is denied for the concealed purpose of revocation. Cf. Piedmont \& Northern Ry. Co. v. United States, (1930) 280 U. S. 469 , and the critique of this decision in the opinion of Rochester Telephone Corp. v. United States, (1939) 307 U. S. 125 at I33, note. 
tually the federal courts have responded to this demand by devising rules of self-limitation.

\section{Prior Resort and Exhaustion}

Two doctrines are commonly resorted to for the purpose of marking off certain areas within which administrative activity enjoys a limited amount of autonomy. The first of these devices ${ }^{26}$ requires that a complaining party, before invoking the courts, must await the action of the competent administrative tribunal ${ }^{27}$ or must exhaust all the administrative remedies available against any action which has already been taken. ${ }^{28}$ That the predominant purpose of the rule is to give due play to administrative expertness appears clearly from its applications, as well as from the exceptions to its application. ${ }^{29}$ Concerning the former, the ground of comity ${ }^{30}$ and the argument

${ }^{2}$ The doctrine has been variously referred to as "exhaustion of administrative remedies," "prior resort to administrative action," or "primary jurisdiction" doctrine.

${ }^{27}$ See, for instance, Texas \& Pacific Ry. Co. v. Abilene Cotton Oil Co., ( 1907 ) 204 U. S. 426; United States Navigation Co. v. Cunard Steamship Co., (1932) 284 U. S. 474; see also the recent decision in Myers v. Bethlehem Shipbuilding Corp., (1938) 303 U. S. 41 at 50-52.

${ }^{28}$ Prentis v. Atlantic Coast Line Co., (rgo8) 2 r 1 U. S. 2 ro. The distinction between the principle of primary jurisdiction and that of exhaustion of remedies is real, although it is commonly disregarded. The former has reference to situations in which original administrative action has not as yet been taken. It is therefore possible that the contemplated act is of the purely administrative type so as to come within the rule of Hayburn's Case and to escape judicial revision entirely. Thus, by applying the prior resort doctrine, the court merely indicates that under the circumstances the anticipated administrative act necessarily will involve a justiciable issue. In other words, the courts have found the separation of powers doctrine inadequate, if not inconvenient, in cases where mixed administrative and justiciable questions are involved. On the other hand, exhaustion of remedies envisages the possibility of hierarchic review of primary administrative action and the doctrine emphasizes the desirability of giving precedence to administrative review over judicial review.

${ }^{20}$ For detailed discussions, see "Administrative Action as a Prerequisite of Judicial Relief," 35 Col. L. Rev. (1935) 230, and Berger, "Exhaustion of Administrative Remedies," 48 Yale L. J. (1939) 981; see also Kirchwey, "The Interstate Commerce Commission and the Judicial Enforcement of the Act to Regulate Commerce," I4 Col. L. Rev. (I914) 2 I I.

${ }^{s}$ Prentis v. Atlantic Coast Line Co., (r 908 ) 2 II U. S. 2 I 0. 
that the administrative remedy is analogous to one at law which, if adequate, bars equity, ${ }^{31}$ are more in the nature of judicial reconciliations of the prior resort and exhaustion doctrines with prevailing notions of judicial power and procedure. Nevertheless, the courts have to some extent been activated by a desire to keep their dockets clear of a great mass of tedious litigation. On the other hand, the exceptions to the requirement of prior resort and exhaustion have been formulated with regard to the absence of technical questions and to the actual or relative nonavailability of administrative relief. $^{32}$

\section{Administrative Finality}

The second rule which is designed to insure respect for the competence of administrative agents is embodied in the doctrine of administrative finality. ${ }^{33}$ Accordingly, "even when [under the exhaustion doctrine] resort to the courts can be had to review a Commission's order, the range of issues open to review is narrow. Only questions affecting constitutional power, statutory authority and the basic prerequisites of proof can be raised. If these legal tests are satisfied, the Commission's order becomes incontestable." ${ }^{34}$ The practical applications of the rule, however, lack the symmetrical beauty implicit in Mr. Justice Frankfurter's terse statement. Questions of constitutional power, as well as of statutory authority, not infrequently depend upon fact determinations; and it is familiar doctrine in American administrative law that "jurisdictional facts" and "constitutional facts" cannot be

an Elliott v. El Paso Electric Co., (C. C. A. 5th, 1937) 88 F. (2d) 505.

* For detailed discussion, see "Administrative Action as a Prerequisite of Judicial Relief," 35 Col. L. Rev. (1935) 230 at 233-240; and Berger, "Exhaustion of Administrative Remedies," 48 Yale L. J. (1939) 981 .

* Dickinson, Administrative Justice, chap. III, p. 39 ff.

${ }^{20}$ Rochester Telephone Corp. v. United States, (1939) 307 U. S. 125 at 139-140. See chap. XI, infra. 
conclusively determined by administrative agencies. ${ }^{\mathbf{3 5}}$ This is so even though the facts to be established may clearly call for the expert knowledge of appointed administrative specialists.

Briefly stated, ${ }^{36}$ whenever the jurisdiction of an administrative body depends upon the existence of specific facts, a court reviewing an administrative determination must reach its own conclusions as to the existence of those facts. ${ }^{37}$ It is nevertheless true that if the latter are "jurisdictional" only in a statutory sense, the statute itself may make the findings of the administrative agency conclusive. ${ }^{38}$ Conversely, if the pres- ence of particular facts is made necessary to the validity of an administrative act by the constitution, ${ }^{\mathbf{3 9}}$ then the fact determination must always be reviewable by the courts. Administrative finality is thus subject to limitations whose extent is largely within the discretion of those courts.

The field actually reserved for administrative fact finding is indicated by the judicial expressions of respect for administrative expertness. In regard to findings of "jurisdictional facts," looking to statutory authority only, the courts have inclined towards admitting the conclusiveness of such findings or have limited their inquiry to the reasonableness of the findings. ${ }^{40}$ On the contrary, judicial scrutiny of "constitutional

${ }^{85}$ Dickinson, Administrative Justice, p. 309 ff.; Dickinson, “Crowell v. Benson: Judicial Review of Administrative Determinations of Questions of 'Constitutional Fact,'" 8o U. Pa. L. Rev. (1932) 1055.

${ }^{30}$ Professor Dickinson's article in 8o U. Pa. L. Rev. ro55 (note 35, supra) should be consulted for a complete treatment of the subject.

${ }^{87}$ See, for instance, Federal Trade Commission v. Klesner, (1 929) 280 U. S. I 9; Interstate Commerce Commission v. Northern Pacific Ry. Co., (rgro) 216 U. S. 538; cf. United States v. Ju Toy, (1905) 198 U. S. 253; Freund, Administrative Powers over Persons and Property (1928), p. 291 ; Dickinson, Administrative Justice, p. 292.

${ }^{38}$ Dickinson, article, 8o U. Pa. L. Rev. I055 at ro59, ro63.

${ }^{30}$ This does not involve the constitutionality of the enabling statute as such, but the constitutional propriety of its application to a given situation. Dickinson, article, $80 \mathrm{U}$. Pa. L. Rev. 1055 at ro68.

${ }^{20}$ Dickinson, Administrative Justice, pp. 310-3 12 ; article, 80 U.Pa. L. Rev. I 055 at 1067 . Professor Dickinson points out the relation between the method of review (certiorari as compared with collateral damage suits) and its scope. 
facts" is more pronounced. In the now classic Ben Avon case, ${ }^{41}$ which was concerned with confiscation as a question of due process, the United States Supreme Court indicated that where constitutional issues are involved the court must form an independent judgment from the record made before the administrative agency. ${ }^{42}$ Finally, Crowell v. Benson, ${ }^{43}$ equally well known because of its enigmatic potentialities, went still further, requiring a trial de novo "for the final determination of the existence of the facts upon which the enforcement of the constitutional rights of the citizen depend." ${ }^{44}$ Thus the courts, although they have refrained from doing so extensively, ${ }^{45}$ may in their discretion subordinate administrative finality whenever such "fundamental or jurisdictional facts" in issue.

41 Ohio Valley Water Co. v. Ben Avon Borough, (1920) 253 U. S. 287.

2 See also St. Joseph Stock Yards Co. v. United States, (1936) 298 U. S. 38 , and Baltimore \& Ohio R. Co. v. United States, (1936) 298 U. S. 349.

(1932) 285 U. S. 22. Dickinson, article, 80 U. Pa. L. Rev. ro55. See also Wood Towing Corp. v. Parker, (C. C. A. 4th, 1935) 76 F. (2d) 770, and Borax Consolidated v. Los Angeles, (r 935 ) 296 U. S. ro; cf. Shields v. Utah Idaho Central R. Co., (1938) 305 U. S. 177, noted in 39 Col. L. Rev. (1939) 693.

${ }^{44}$ Crowell v. Benson, (1932) 285 U. S. 22 at 56. The full passage is as follows: "In relation to these basic facts, the question is not the ordinary one as to the propriety of provision for administrative determinations. Nor have we simply the question of due process in relation to notice and hearing. It is rather a question of the appropriate maintenance of the Federal judicial power in requiring the observance of constitutional restrictions. It is the question whether the Congress may substitute for constitutional courts, in which the judicial power of the United States is vested, an administrative agency-in this instance a single deputy commissioner-for the final determination of the existence of the facts upon which the enforcement of the constitutional rights of the citizen depend. The recognition of the utility and convenience of administrative agencies for the investigation and finding of facts within their proper province, and the support of their authorized action, does not require the conclusion that there is no limitation of their use, and that the Congress could completely oust the courts of all determinations of fact by vesting the authority to make them with finality in its own instrumentalities or in the Executive Department. That would be to sap the judicial power as it exists under the Federal Constitution, and to establish a government of bureaucratic character alien to our system, wherever fundamental rights depend, as not infrequently they do depend, upon the facts, and finality as to facts becomes in effect finality in law."

${ }^{45}$ See the note in 39 Col. L. Rev. (1939) 693.

${ }^{40}$ Crowell v. Benson, (1932) 285 U. S. 22 at 63. 


\section{Administrative Law Reforms}

The discretionary element in both the exhaustion and the finality doctrines must be kept well in mind if proposed administrative law reforms in this country are to be intelligently appraised. Any legislative attempts to enlarge, or even to fix, the circumference of administrative autonomy is hemmed in by judicial conceptions of basic constitutional principles. Legislation which transcends the indicated limits will escape a declaration of unconstitutionality only if it is susceptible of an interpretation that will neutralize those provisions not in harmony with the announced principles. It must also be observed that the utility of proposals tending to strengthen rather than to curtail court control of the administrative may run afoul of the same barriers. The defunct Logan Bill, ${ }^{47}$ first sponsored $^{48}$ and later abandoned ${ }^{49}$ by the American Bar Association, embodied a scheme for the creation of a federal administrative court or, as it was later termed, "a consolidation of existing legislative courts." ${ }^{\text {50 }}$ This organism, to be composed of trial and appellate divisions and nominally intended "for the gradual segregation of judicial functions now exercised by federal administrative agencies," 51 would actually have adjudicated controversies arising from administrative action. Being a legislative court, it would have had the power, not enjoyed by the constitutional courts, to pass on administrative questions. ${ }^{52}$ Assuming that the personnel of this tribunal would have been selected with a view to administrative qualifications and that through its routine the court would in any case have soon developed into an expert

\footnotetext{
${ }^{17}$ S. 3787 and H. R. 12297, 74th Cong., 2d sess. (1936).

46 6 I Rep. A. B. A. (1936) 720 at 760.

${ }^{40} 62$ Rep. A.B.A. (1937) 789 at 805.

${ }^{50} 62$ Rep.A.B.A. (1937) 789 at 805.

"6 6 I Rep.A.B.A. (1936) 720, recommendation 2 (a).

"2upra, note 11 .
} 
body, the net gain would still have been disproportioned to the effort spent. For while all disputes to come before the court would have received specialized treatment, the limitative interpretations of the exhaustion and finality principles in an indeterminate number of instances would have reduced the effect of the scheme to hardly more than a multiplication of available appeals. Viewed in this light, at least the ultimate object of one feature of the new Administrative Law Bill, ${ }^{53}$ which has not fared well with the critics, ${ }^{54}$ deserves some credit. ${ }^{55}$ Section 4 of the bill provides for intra-agency review by specially organized review boards whose personnel would be recruited from within each agency. The institution of hierarchic appeals in the case of all administrative agencies is indispensable to an integrated administrative process and contributes substantially to the respect which administrative competence should and can command. ${ }^{56}$

However, no legislative proposals nor new designs for the judicial or administrative apparatus are of themselves sufficient to insure the best possible relationship between the two departments of government. The problem is not merely one of mechanics; it is also one of attitudes. In this country administrative autonomy, because of constitutional conceptions, is to a large extent dependent upon judicial self-restraint. It is important, therefore, that this restraint should be carried to the point where the interplay of adjudication and adminis-

${ }^{*}$ S. 9 I 5, H. R. 4236, 76th Cong., ist sess. (1939). See McGuire, "The American Bar Association's Administrative Law Bill," I La. L. Rev. (1939) 550. See also infra, chaps. VI, XI.

s Jaretzki, "The Administrative Law Bill: Unsound and Unworkable," 2 La. L. Rev. (1 940) 294; Symposium, "American Bar Association's Administrative Law Bill," 34 Ill. L. Rev. (r940) 641; see also Jaffe, "Invective and Investigation in Administrative Law," 52 Harv. L. Rev. (1939) 1201 at $1225-1232$.

${ }^{50}$ The procedural and technical defects of section 4 are fully discussed by Professor McAllister in his contribution, "Administrative Adjudication and Judicial Review," to the Symposium in 34 Ill. L. Rev. 641 at 680, and by Mr. Jaretzki in the article in $2 L a$. L. Rev. 294 at $311-315$.

${ }^{\circ}$ Cf. Jaffe's article, 52 Harv. L. Rev. 1201 at 1227. 
tration becomes cooperative rather than competitive. To this end "we must learn, as quickly as we may, how to make popular government at once responsible, capable, and just." Manifestly, traditional prejudice against administrative activity, born of a habit of thinking, is most apt to recede in the proportion that the tasks assigned to the administrative are customarily well done. ${ }^{58}$ Consequently the constant supply of adequately trained personnel ${ }^{59}$ to take over those tasks is essential, and a critical glance at the law schools, in which a large number of our public servants receive their preparation, is pertinent. Philosophically there may be no fundamental distinction between private law and public law. However, in our law schools, which are primarily geared to preparation for immediate practical tasks, the differentiation of private and public law courses in the curriculum is in need of greater emphasis. A better integration of the public law courses would be of benefit to our future public servants.

\footnotetext{
${ }^{57}$ Fuchs, "Concepts and Policies in Anglo-American Administrative Law Theory," 47 Yale L. J. (1938) 538 at 576.

${ }^{68}$ Landis, The Administrative Process, pp. 143-144. Cf. Cooper, "Administrative Justice and the Role of Discretion," 47 Yale L. J. (1938) 577 at 601.

"See the proposal of the American Bar Association concerning "A Yearly Clinic to Study Administrative Processes," 62 Rep. A. B. A. (1937) 789 at 801 ; cf. Ballantine, "Administrative Agencies and the Law," 24 A.B. A.J. (1938) rog.
} 


\section{PART III}

\section{THE REVIEW POWERS}

OF THE

ORDINARY COURTS IN FRANCE 


\section{Chapter VI}

\section{Review of Administrative Regulations}

T $N$ FRANCE, under the principle of differentiated agencies, a system has evolved which sanctions adminis1 trative finality in all matters of administrative concern, and the sanction extends to actual administration, as well as to the adjudication of ensuing controversies. Nevertheless, a mere summary conclusion that all matters not specifically interpreted to have administrative content are cognizable by the ordinary courts would fall far short of an accurate appraisal of the French administrative system. Judicial authority in regard to administrative action at certain points has always asserted itself and has not been content with concessions of jurisdiction. These assertions indicate areas in which public and private interests overlap and compete and where the actual review powers of the ordinary courts of France assume a familiar significance.

\section{A. THE QUESTION OF THE LEGALITY OF REGULATIONS}

Despite the firm language of the enactments prohibiting judicial interference with administration, ${ }^{1}$ there have been read into the differentiation of agencies nonstatutory exceptions which actually permit the ordinary courts of France to control administrative action to some extent. This power of the civil courts, which generally rests upon illegality, varies in scope with the nature of the act ${ }^{2}$ before them, and especially in the case of administrative regulations it has been subject to fluctuating limitations.

Administrative regulations result from the exercise of the power of administrative agencies to make rules and to adopt

\footnotetext{
${ }^{1}$ See p. 13, supra.
}

${ }^{2}$ See Duguit, Traité de droit constitutionnel, 2d ed. (1921), Vol. 2, p. 263 ff. 
ordinances. ${ }^{3}$ Such regulations have been defined as "obligatory rules imposed by a public agency other than the legislature." ${ }^{4}$ For a long time it has been conceded that the courts have power not only to interpret these regulations but also to inquire into their legality. ${ }^{5}$ Likewise, a duty on the part of the courts to exercise these powers has been recognized. ${ }^{8}$ Historically, the acknowledged jurisdiction of the ordinary courts in regard to the interpretation and legality of administrative regulations has its origin in a famous statutory exception to * the rule prohibiting the judicial agencies from obstructing the actes de la puissance publique. By virtue of the Penal Code of $1832,{ }^{7}$ the judicial courts were permitted to interpret and to verify the legality of certain regulations before they proceeded to impose the penalties provided for their transgres-

'Aucoc, Conférences sur l'administration et le droit administratif, $3 \mathrm{~d}$ ed. (1885), Vol. I, p. 123 ff.; Ducrocq, Cours de droit administratif, 7th ed. (1897), Vol. 1, pp. 81 ff., 178 ff.; Moreau, Le règlement administratif (1 902); Hauriou, Précis de droit administratif, 1oth ed. (19.2 I), p. $60 \mathrm{ff} ., 12$ th ed. (1933), p. 555; Berthélemy, Traité élémentaire de droit administratif, $13^{\text {th }}$ ed. (1933), p. I 21 ff.; Esmein, Eléments de droit constitutionnel, français et comparé, 7th ed. (1921), Vol. 1, pp. 536, 537, Vol. 2, p. 75 ff.; Duguit Traité, Vol. 2, p. 182 ff.; Duguit, Law in the Modern State, English translation (1919), p. 79 ff.; Bonnard, Précis de droit administratif (1935), p. 246; Waline, Manuel élémentaire de droit administratif (r936), p. $290 \mathrm{ff}$.

- Moreau, p. 2.

'Aucoc, Vol. 1, p. 499 ff.; Ducrocq, Vol. 3, p. 291 ; Moreau, p. 260; Esmein, Droit constitutionnel, Vol. I, pp. 536, 537; Duguit, Traité, Vol. 3, pp. 49 ff., 721 ; Dareste, Les voies de recours contre les actes de la puissance publique (1914), pp. 165, 167; Hauriou, Précis, roth ed., p. 69, 12th ed., p. 568; Appleton, Traité élémentaire du contentieux administratif (1927), p. I05 ff.; cf. Jèze, Les principes généraux du droit administratif, 3d ed. (1925), p. 378.

- Ducrocq, Vol. I, p. 84: "The principle that regulations are subject to the limitations of the laws has received the double sanction of the recourse to the Conseil d'Etat for excess of power, and the obligation of the judicial authorities not to apply regulations until after having verified their legality." (Italics added.) See also Moreau, p. 261 ; Duguit, Traité, Vol. 2, p. 189 , Vol. 3, p. 49; Dareste, p. 165, note 3, citing note by Sarrut, D. 1897.2.225; Appleton, p. ro5.

${ }^{7}$ Code pénal, art. $47 \mathrm{I}, \S_{\mathrm{I}} 5$, confers upon the judicial courts power to convict, and subject to the penalties provided, "those who shall have offended - against regulations lawfully made by administrative agencies, and those who shall not have complied with regulations or orders issued by municipalities." (Italics added.) 
sion. ${ }^{8}$ However, even before the enactment of this statute, and as far back as I $8 \mathrm{IO}$, the Cour de cassation insisted upon this right of the courts to inquire into administrative regulations. ${ }^{9}$ In doing so the courts carefully avoided asserting the power to annul regulations or to interpose direct obstacles to the execution of administrative orders. But they took the position that they must refuse any aid in the execution of unlawful orders because they had authority to grant judicial enforcement only where it served the execution of laws. Consequently, before they could intervene on behalf of an administrative agency they were bound to ascertain whether or not the act to be enforced was legal and was therefore law. ${ }^{\mathbf{1 0}}$ Thus, in I 830, a civil court ${ }^{11}$ refused to apply an administrative regulation on the ground that "ordinances may not be issued except for the purpose of executing or maintaining the laws, and that the regulation before it would, on the contrary, have the effect of violating a statute." The regulation involved attempted to suspend the freedom of the press. ${ }^{12}$ Giving due consideration to this attitude of the judicial courts, it is not surprising that the enactment of I 832 came to be interpreted extensively at once, and that the power of the courts to refuse to enforce police regulations which they deemed il-

${ }^{8}$ Laferrière, Traité de la juridiction administrative et des recours contentieux, 2d ed. (1896), Vol. 1, p. 480 ff.; Berthélemy, Traité, pp. 1104I 106; Réglade, "L'Exception d'illégalité en France," 40 R. D. P. (1 923 ) 393; Waline, Manuel, p. 295.

- Laferrière, Vol. I, pp. 481-482, and the cases cited in the note on p. 482; Berthélemy, Traité, p. 1105; Moreau, pp. 260-261, note 6, and cases cited there; Garner, "Judicial Control of Administrative and Legislative Acts in France," $9 \mathrm{Am}$. Pol. Sci. Rev. (1915) 637; Garner, "French Administrative Law," 33 Yale L. J. (1924) 597.

${ }^{10}$ See the opinion of the commissaire du gouvernement in the Septfonds case (infra, note $4 \mathrm{I}$ ), S. 1 923.3 .49 , D. I $924.3 .4 \mathrm{I}$, and the accompanying note by Hauriou, La jurisprudence administrative (1929), Vol 1, pp. 50, 52, 53.

${ }^{12}$ The Tribunal de commerce de la Seine; see Hauriou, ibid., p. 53.

12 The ordinance of July 25, 1830, was held to violate the law of July 18 , 1828 , regulating the freedom of the press. 
lega ${ }^{13}$ was, for a time, held to extend to all types of administrative regulations. The statute indeed was held to express nothing more than the legislative sanction of a "pre-existing and superior rule." ${ }^{14}$

\section{B. THE INTRINSIC NATURE OF REGULATIONS}

It was inevitable that the doctrine of the differentiation of administrative and judicial agencies should lead to virtually insoluble difficulties at this juncture. Actually, it complicated the question of jurisdiction over regulations to a degree which, up to very recent times, precluded reconciliation of the respective attitudes of the two sets of courts. ${ }^{15}$ This condition was the result of mutual insistence that the application of the doctrine of differentiated agencies depended upon the intrinsic nature of the rule-making function and of administrative regulations, ${ }^{16}$ a matter itself in dispute.

The theory of delegated legislation has been quite generally rejected by modern French writers. ${ }^{17}$ On the other hand, the legislative character of administrative regulations

${ }^{13}$ Laferrière, Vol. 1, pp. 481, 483; Duguit, Traité, Vol. 3, p. 51 .

${ }^{14}$ Ducrocq, Vol. 3, p. 292. See also Duguit, Traité, Vol. 3, p. 52 . Appleton, pp. r 06-107 (and cases cited): "At this point judicial doctrine began to see in

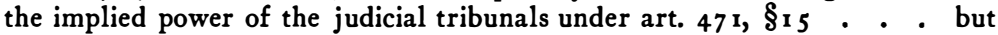
an individual application of a general, presupposed rule, according to which the courts may interpret regulatory acts and test their legality in connection with controversies over which they have jurisdiction." (Italics added.) The entire development is set out in the opinion of Commissaire Matter in the Septfonds case and in Hauriou's accompanying note (see note 10, supra).

${ }^{16}$ Bonnard, Précis, p. 162 ; Appleton, Supp., pp. 1 5-16.

${ }^{16}$ Cf. Waline, Manuel, p. 7 ; Duguit, Traité, Vol. 3, p. $182 \mathrm{ff}$.

${ }^{17}$ Esmein, Droit constitutionnel, Vol. 2, p. 81; Duguit, Manuel de droit constitutionnel, 3d ed. (1918), p. 506; cf. Duguit, Traité, Vol. 2, p. 414, Vol. 3, p. 144; Hauriou, Précis, 1 oth ed., pp. 61, 68, I 2 th ed., pp. 556, 567, 576; Moreau, p. $164 \mathrm{ff}$.; Réglade, 40 R. D. P. at 403; Berthélemy, Traité, pp. 1 24-1 25 ; Jèze, Principes, p. 378 ff. Cf. Dareste, p. 165 , and a case cited there decided by the criminal division of the Cour de cassation in 1845 , using this language: "the ordinance of May 2, 1 841, being but the result of a delegation of legislative power, was essentially in the nature of a law and its interpretation belongs to the ordinary courts." 
persists in being partly acknowledged, although it is the subject of much controversy. ${ }^{18}$ The disputable argument has been advanced that the character of regulations is nonlegislative because of the sole fact that they emanate from agencies other than the legislature. But neither the assimilation nor the distinction of the two types of general rules resulting from legislation and from rule-making could contribute materially to the clarification of the complex situation confronting courts and theorists. If Duguit's analysis, unquestionably correct in its emphasis upon the two-fold quality of the regulation, is accepted, it is possible to avoid objection to the power of the courts to interpret general administrative rules. For the constitutional prohibition contemplated administrative acts only, not legislative acts; and the interpretation of legislative acts, by whomever promulgated, is certainly the very essence of

This interesting problem cannot be considered except by way of the most perfunctory allusion, because of the proportions it has assumed in the discussions of both continental and Anglo-American writings. See, e.g., Jacoby, "Delegation of Powers and Judicial Review: A Study in Comparative Law," 36 Col. L. Rev. (1936) 871 ; Jellinek, Gesetz und Verordnung (1887); Mayer, Deutsches Verwaltungsrecht, 2d ed. (1914), Vol. I, pp. 65, 68-70.

${ }^{18}$ The principal exponent in France of the theory of intrinsic identity of laws and regulations is Duguit; see Traité, Vol. 2, pp. 182, 189, Vol. 3, pp. 49 ff., 721 . In the same sense, Moreau, p. 60; Réglade, $40 R$. D. P. at 401 ; Bonnard, Précis, p. 247; Jèze, Principes, p. 28. For the contrary view, see among others, Hauriou, Précis, roth ed., p. 54 ff. [However, the insistence upon a fundamental difference is no longer to be found in the 12 th edition (p. $563 \mathrm{ff}$.) and one may rather conclude that the similarity is implicitly admitted.]; Berthélemy, Traité, p. 122 ff.; Appleton, p. 108.

The courts seem to favor the theory that although formally regulations are administrative they bear a notable resemblance to the laws. See, e. g., Compagnie générale de navigation v. Grandperrin, (Cass.) D. 1908.1.76, holding that the judicial agencies could interpret a regulation concerning river navigation because it was not an "individual and special administrative act" but a regulatory ordinance made under the police power conferred upon the administrative by law, and therefore "partaking of the character of a law." Similarly the same court, in Guillou v. Préfet de la Seine [S. I 9 I 8-1 9 I 9.1. I 94 at 1 95, cited by Duguit, Traité, Vol. 2, p. 190, Vol. 3, pp. 721-722; see the note in 34 R. D. P. (1917), p. 620], said that the "regulations . . . do not constitute special and individual administrative acts . . . but general provisions made by virtue of the rule-making power of the administration, which consequently partake of the character of the laws." The same language was employed by the Tribunal des conflits in the Septfonds case, infra, note $4 \mathrm{I}$. 
the judicial function. ${ }^{19}$ Conversely, the remaining adminis- trative quality of regulations would still prevent the judicial courts from ascertaining their legality as a condition precedent to their application.

Admittedly the argument involved is highly formalistic. Nevertheless it deserves to be elaborated further, if only to demonstrate the complications into which the seemingly welldefined doctrine of differentiated agencies has led. While it has not been difficult to maintain that, due to their legislative aspect, regulations may be interpreted by the ordinary courts without violating the principle of judicial noninterference, ${ }^{20}$ the recognition of a power in those courts to inquire into their legality has necessitated an exception to the doctrine of differentiation. ${ }^{21}$ For, the nullification incident to declarations of illegality most clearly constitutes interference with administration. But the impediment of the doctrine can be - avoided by disregarding the administrative origin of regulations, and by deriving from their legislative character not only the power and duty of the courts to interpret them, but also the power to refuse application for illegality. ${ }^{22}$ In the

${ }^{10}$ Duguit, Traité, Vol. 2, p. 1 89, Vol. 3, pp. 49, 721.

${ }^{20}$ Ibid., Vol. 3, pp. 50-52.

Ibid. p. 52; Duguit insists that this exception, originally statutory and limited to one specific type of ordinance (art. 471, $\S_{15}$, Code Pénal, supra, note 7), came to be given general scope "par la force 'même des choses." "

${ }^{22}$ See the note by Sarrut accompanying the decision in Raoulx v. Gallet, D. 1897.2.225 at 226:2: "The ordinary courts have a right to interpret these $\checkmark$ regulatory decrees; since they are in the nature of laws there is no violation of the principle of the separation of powers. . . . The ordinary courts may, and are even required to, verify the legality of these regulatory decrees, that is, they must inquire whether the chief executive did not exceed his delegation, and whether he observed the form and other requirements imposed by law. For in doing so, far from exercising an improper control over the law itself . . . they [the courts] on the contrary cause the text and spirit of the law to be protected in regard to the act which the law authorized the chief executive to accomplish within designated limits." (Quoted by Dareste, p. 165 , note 3.)

See also Ducrocq, Vol. 1, p. 84, Vol. 3, p. 29.1 ; cf. Berthélemy, Traité, p. 26, note 1 . 


\section{REVIEW OF ADMINISTRATIVE REGULATIONS 83}

very case $^{23}$ repeatedly referred to by Duguit, decided upon the report of an outstanding jurist of the day, ${ }^{24}$ the court said verbatim: "for that reason [that regulations partake of the nature of laws $]^{25}$ it is for the judicial authorities . . . to test their legality and to interpret their meaning." On the other hand, the power to declare regulations illegal has also been defended on the ground that it is an integral part of the judicial function, whether exercised by the administrative or the ordinary courts, and therefore is not dependent upon the intrinsic nature of regulations. Thus Professor Hauriou very interestingly has referred to the principle of the "supremacy of the law" insisting that every court must be able to refuse to apply regulations which are illegal. ${ }^{26}$

${ }^{28}$ Guillou v. Préfet, S. 1918-1919.1.r94, cited supra, note 18.

${ }^{4}$ Ambroise Colin; see Duguit, Traité, Vol. 3, p. 722 ; note, 34 R. D. P. (1917) 623 .

${ }^{25}$ See note 18 , supra.

${ }^{26}$ Hauriou, Précis, roth ed., p. 69 (see I 2 th ed., p. 568); cf. Appleton, p. ro9. As far as the differentiation of agencies is concerned, Hauriou, while finding nothing in the relevant statutes in the way of this power of the ordinary courts, considered the precept displaced by the more important rule that "le juge de l'action doit être juge de l'exception." See Hauriou, Jurisprudence, Vol. I, p. 60 (note under the Septfonds case) and Précis, r 2th ed., p. 568.

In the roth edition of his Précis (p. 55) Hauriou circuitously argued that administrative regulations "are not laws" for "they can be declared illegal." It would seem, however, that the existence or nonexistence of a power in the courts to make declarations of illegality depends upon the constitution rather than upon the nature of the impeached act. Cf. Duguit, Traité, Vol. 2, p. I 933 but see Berthélemy, Traité, p. I 23 , note I, interpreting the Guillou decision, supra, notes 18 and 23 , as not assimilating regulations to laws, "because it affirms the right of the courts to inquire into their legality."

On the absence of judicial authority in France to declare parliamentary laws illegal, see: Laferrière, Vol. I, p. 483; Moreau, p. 263, note i ; Dareste, p. I63, note I ; Esmein, Droit constitutionnel, Vol. 1, p. 563; Duguit, Traité, Vol. 2, p. 193; Duguit, Etudes de droit public (1903) Vol. 2, p. 520 ff. See also Duez, "Le contrôle juridictionnel de la constitutionnalité des lois en France," in Mélanges Maurice Hauriou (1929), p. 2 I I ff., disapproving contemporary efforts to vest the courts with power to question the constitutionality of the acts of the legislature; also the note in $53 R$. D. P. (1936) 670 ff., concerning two recent decisions of the Conseil d'Etat [Arrighi and Coudert, Rec. 1936.966, S. 1937.3.33, 54 R. D. P. (1937) 370]. Cf. Waline, Manuel, p. 7. See also Ducrocq, Vol. I, p. 19, as to the former power of the Senate to determine the constitutionality of laws. 
C. EFFECTS AND RATIONALE OF THE JURISDICTION OF THE ORDINARY COURTS OVER REGULATORY ACTS

In view of the doctrine of differentiation of agencies, considerable emphasis has been placed upon the fact that a judicial declaration of the illegality of a regulation is but a refusal to apply the regulation in a specific instance, and amounts in no way to an annulment. ${ }^{27}$ Since annulment can be obtained only through the administrative jurisdiction, i. e., the Conseil d'Etat, ${ }^{28}$ a regulation stigmatized as illegal by an ordinary court nevertheless continues in force. Consequently, so long as an administrative agency does not see fit to revoke a given regulation, or so long as the regulation has not been annulled by the Conseil d'État upon a recourse for excess of power, each successive litigant whose right of action or defense depends upon the invalidity of the same regulation must renew the collateral attack. This circumstance seemed to open one more avenue of escape from the confusion which necessarily surrounded all efforts to harmonize the power of the ordinary courts over the quasi-legislative acts of the administrative with the principle of noninterference. The argument was made $^{29}$ that the statutory provisions embodying the principle must be given a practical interpretation to the effect that (a) every governmental agency ought to be left to fulfill its mission with absolute freedom, (b) every act by which one agency encroaches upon the freedom of action of another should be deemed void. Both of these rules were supposed to justify the contested review powers of the courts. First, without these powers the courts could not freely perform their adjudicating functions, and secondly, in pronouncing regula-

${ }^{27}$ Laferrière, Vol. 1, p. 504; Ducrocq, Vol. 1, pp. 84-85, Vol. 3, p. 292 ; Moreau, pp. 263, 265-266; Dareste, p. I69 (note particularly the interesting analysis of authorities in note 1); Duguit, Traité, Vol. 3, pp. 50, 722 ; Réglade, 40 R. D. P. at $416 \mathrm{ff}$; Hauriou, Jurisprudence, Vol. 1, p. 59; Appleton, p. 110.

${ }^{28}$ Supra, chap. III.

${ }^{20}$ Moreau, p. 263. 
tory orders illegal the ordinary courts did not encroach upon the administrative sphere of action since they merely refused to give a concurrence to which the particular administrative acts were not entitled. ${ }^{30}$ But even though this theory pretends to break with the "obscure notion" ${ }^{31}$ of the traditional differentiation of agencies, the substituted "clear notion" of "the relative independence of the different agencies"32 presents little more than a change of argument and rationalization.

The fact that an administrative regulation remains intact notwithstanding a judicial declaration of illegality is comparatively unimportant. Consistent refusal by the highest judicial tribunal to apply a regulation certainly may become an effective means of forcing an administrative agency to repeal or to amend its act. ${ }^{33}$ The administrative department can enforce its regulations manu militari only in exceptional circumstances; ordinarily it is dependent upon judicial machinery for the enforcement of its rules and orders. ${ }^{34}$ Except in case of urgency ${ }^{35}$ the ordinary courts were thus actually placed in a position where they could exercise a certain control over the policies of the administration. ${ }^{36}$ This result was not a desirable one in all respects, particularly because it could lead to the anomalous situation where a regulation declared illegal by one of the ordinary courts was treated as valid and applicable by the administrative courts. ${ }^{37}$

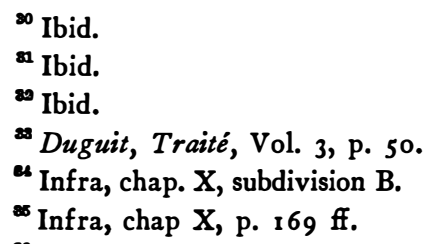

${ }^{\text {" }}$ Hauriou, Jurisprudence, Vol. 1, p. 63; cf. Berthélemy, "De l'exercice de la souveraineté par l'autorité administrative," 21 R. D. P. (1904) 209 at $221-$ 222. Moreau ( $p_{\text {. 263 }}$ ) evidently underestimated the potential effects of the power of the ordinary courts in this respect.

${ }^{\text {" }}$ See Laferrière, Vol. 1, p. 504 ff. 
Obviously the problem of the reviewability of administrative regulations was fraught with inconsistencies. Professor Appleton in his treatise on administrative jurisdiction ${ }^{38}$ suggested that the situation could be clarified only by a proper understanding of the doctrine of the separation of powers, which he maintained should be taken in a political rather than a strictly functional sense. Conceding the mixed legislativeadministrative nature of regulations, he realized that the separation of powers as previously interpreted could only lead to an impasse. For, "if regulations are deemed to be laws, the ordinary courts cannot adjudge them illegal or refuse to apply them without violating the principle of the separation of powers and the law of August I 6-24, I 790, title 2, article IO; on the other hand, if regulations are looked upon as administrative acts, the courts can no more test their legality because this would be to misconstrue the principle of the differentiation of the judicial and administrative functions, proclaimed by title 2, article I 3 of that statute." ${ }^{39}$

\section{THE SEPTFONDS CASE COMPROMISE}

During the time when legal writers searched for a more realistic basis, the judicial courts conservatively continued to predicate their review powers on the legislative quality of administrative regulations. Many of the decisions of the Cour de cassation and of the lower courts contain assertions of the right to interpret and to declare illegal general acts on that ground. ${ }^{40}$ Not until I 923 did the Tribunal des conflits signify its dis-

\footnotetext{
${ }^{88}$ Pp. r $09-1$ r 0.

Ibid., p. ro8. Cf. the opinion in the Septfonds case, D. 1924.3.41 at 44 (VIII), infra, note $4 \mathrm{I}$.

${ }^{40}$ See the cases collected by Appleton, p. 107 ; Hauriou, Jurisprudence, Vol. I, p. $52 \mathrm{ff}$. In one instance, Martin v. Ville de Marseille, S. $1918-1919.1 .73$, the Cour de cassation seemed to deviate from a consistent line of decision, holding that the judicial courts could not interpret an ambiguous term in a municipal taxing statute. However, Duguit, (Traite, Vol. 3, p. 5o) considers the decision merely an "accidental error." Cf. Hauriou, Jurisprudence, Vol. I, p. 54.
} 
agreement with these holdings in the much discussed decision in the case of Septfonds v. Chemins de fer du Midi. ${ }^{41}$ The Tribunal adopted the opinion of Commissaire Matter, who argued the case for the government. After analyzing minutely the question which was before the court, the commissaire du gouvernement suggested the necessity of making a distinction between the power of the courts to interpret regulations and the power to test their legality. The argument was founded exclusively upon the basic law $^{42}$ which prohibits the judicial agencies from "disturbing the operations of the administrative department." The commissaire concluded that interpretation which "follows, conforms to and applies" the regulation, does not constitute an interference, while "a declaration of illegality and a refusal to apply it wipes out the regulation, and consequently interferes with the administrative action." ${ }^{43}$ Consequently the power of the ordinary courts to interpret administrative rules was conceded and the right to determine the question of legality was denied.

It is of interest to note that already in an earlier case ${ }^{44}$ the Tribunal des conflits seems to have attempted to create an exception to the rule by which the courts inquired into the legality of the administrative acts. That case involved a regulation issued by the military authorities in time of war and the Tribunal held the civil court bound by the regulation. The decision was severely criticized and it was insisted that not even the exigencies of the war could justify an "extension in the application of the principle of the differentiation of agencies." 45

1 D. 1924.3 .41 , S. 1923.3 .49 ; see Hauriou, Jurisprudence, Vol. I, p. 50 ff.; Précis, 12 th ed., p. 568; Appleton, p. 111 , Supp., p. 16; Berthélemy, Traité, p. 1 24, note; Bonnard, Précis, p. I62; Waline, Manuel, p. 51.

${ }^{2}$ Law of Aug. 16-24, 1790, tit. 2, art. 1 3, supra, p. 13, note 38.

${ }^{\infty}$ D. $1924 \cdot 3 \cdot 4$ I at $44: 2$ (VIII).

4 Chemins de fer du Nord v. Vion et fils, S. 1917.3.1, D. 1916.3.57, decided July 29, 19 1 6.

${ }^{45}$ See Réglade, 40 R. D. P. at 406; Hauriou, Jurisprudence, Vol. I, p. 34 ff., p. 57 and note, S. $1917 \cdot 3.1$. 
The doctrine of the Septfonds case reserving the question of legality for the administrative courts became the accepted rule after the Cour de cassation, in $1926,{ }^{46}$ asserted once more the jurisdiction of the judicial courts over the legality of administrative regulations. The subsequent adherence on the part of the judiciary to the Septfonds compromise is reflected in the case of Lamy v. Chemins de fer du Nord, ${ }^{47}$ decided by the Cour d'appel of Paris in 1930.

\section{E. CONCLUSION AND COMPARISON}

The rule announced by the Tribunal des conflits in the Septfonds case standing by itself seems to mark a return to a stricter interpretation of the differentiation of agencies and the consequent curtailment of the scope of judicial review of administrative regulations. Such a development seems to be in harmony with the previously discussed trends in the direction of autonomy in all essentially administrative matters. However, it would be a grave error to assume that the sequel of the Septfonds doctrine was a complete surrender by the judiciary of previously asserted power. The true import of the doctrine is indicated by the exceptions to which the rule is subject. These exceptions were carefully pointed out by the commissaire du gouvernement, although they were not involved in the case. ${ }^{48}$ They were grouped under two separate categories, the first of which derives from express statutes. Most important is section I 5 of article 47 I of the penal code, interpreted to confer power on the judicial tribunals to verify the legality of all regulations imposing criminal penalties. Secondly, plenary jurisdiction over all matters of indirect taxation has been given to the civil courts. Of far greater significance, however, is the reference to certain nonstatutory

*A Alamichel v. Ville de Vichy, S. 1 926.1.213, cited Bonnard, Précis, p. 162.

${ }^{87}$ Gaz. Pal. 1930.1.684. See the note there; Appleton, Supp., p. 16.

${ }^{43}$ D. $1924 \cdot 3 \cdot 41$ at $44: 2-45: 1$. 
exceptions comprised in the second group. The commissaire, citing various authorities, ${ }^{49}$ defended the theory that the ordinary courts could always determine whether an administra- .. tive agency had acted within its power in issuing any regulation affecting ( $\mathrm{I}$ ) personal liberty, and (2) personal status or property rights. ${ }^{50}$

That the Septfond's decision has not been understood to inaugurate a sweeping change is very probably indicated by the fact that criticism has been confined to its procedural implications. It must be borne in mind that the abolition of judicial review of the legality of regulations is not synonymous with complete absence of court review. Ascertainment of legality, so far as affected by the Septfonds decision, has merely been remitted to the exclusive jurisdiction of the administrative courts. Therefore, if a judicial court, called upon to apply an administrative regulation, is in doubt as to its legality, it must refer the issue to the Conseil d'Etat. ${ }^{51}$ That this procedural complication was undesirable because of the additional expense and delay involved is evident. ${ }^{52}$

${ }^{40} \mathrm{D} .1924 \cdot 3 \cdot 41$ at $45: 1$.

${ }^{50}$ Infra, chap. IX, subdivision $A$.

${ }^{5}$ Prior to the Septfonds case the Conseil d'Etat not infrequently had to pass upon the legality of regulations which had been referred to it by lower judicial courts, even though the latter might have decided the issue themselves under art. 47 I, $\S_{1} 5$ of the Code Pénal (supra, note 7 ). See Réglade, 40 R. D.P. at 424; Hauriou, Jurisprudence, Vol. 1, p. 6o, Précis, i 2th ed., p. 568.

Technically the issue of legality in these cases becomes what is known as a question préjudicielle. The doctrine of the questions préjudicielles through a system of declaratory judgments operates to keep intact the respective spheres of administrative and ordinary jurisdictions. Thus whenever the decision of a controversy properly before a court necessitates the determination of a question that may not be passed upon by that court, that question must be referred to the competent tribunal. See Laferrière, Vol. I, p. 492 ff.; Appleton, p. $126 \mathrm{ff}$.; Hauriou, Précis, roth ed., p. 877 ff.; Bonnard, Précis, p. 159 ff.; Waline, Manuel, p. $158 \mathrm{ff}$. The courts will not allow a question préjudicielle obviously designed to delay judgment; cf. the conclusions (VIII) of the commissaire in the Septfonds case, D. I 924.3.4I at 45. See the recent decisions of the Tribunal des conflits in Société des forces motrices d'Arrens v. Pahu, and Durand v. Société L'Energie électrique Rhône et Jura, D. 1934.3.57 (6o) (and note by Prof. Pepy), noted 52 R. D. P. (1935) 329.

${ }^{60}$ Hauriou, Jurisprudence, Vol. 1, pp. 51-52, Précis, 1 2th ed., p. 568, note I 9 ; Appleton, Supp., p. 16. 
In the United States the separation of powers as originally conceived has been favorable to judicial control of the legality of the quasi-legislative acts of administrative agencies. Administrative regulations are deemed to grow out of the exercise of delegated power, and the courts may invalidate the delegation by the legislature if it is too broad. ${ }^{53}$ Morever, they may set aside the regulation if the administrative body in making it has exceeded the delegation. ${ }^{54}$ In the adjudication of controversies the courts have reserved to themselves the interpretation of regulations although weight is given to prior consistent administrative interpretation.

The circumstance that American administrative law has been unencumbered by the difficulties accompanying the development of the French droit administratif makes the similarity of the net result of the two systems all the more impressive. True, the French judiciary was finally limited to the interpretation of administrative regulations. However, the statutory exceptions, read in conjunction with the general doctrine that the legality of any general rule encroaching upon personal liberties or property rights is subject to judicial appraisal, render the review powers of the French courts comparable, if not equal, to those of the constitutional courts in the United States.

The proposal of the Administrative Law Bill ${ }^{55}$ to vest the United States Court of Appeals for the District of Columbia with power "to hear and determine whether any [administrative] rule ... is in conflict with the Constitution of the

${ }^{88}$ Panama Refining Co. v. Ryan, (1 935) 293 U. S. 388 ; A. L. A. Schechter Poultry Corp. v. United States, (1935) 295 U. S. 495. Cf. Waline, Manuel, pp. 321-24, referring to certain extreme instances of legislative "abdication" in France during the period 1924-1935.

${ }^{4}$ Pacific States Box \& Basket Co. v. White, (1 935 ) 296 U.S. 176.

${ }^{65}$ S. 915, H. R. 4236 , 76th Cong., Ist sess. (1939), $\$ 2 ; 62 \operatorname{Rep} . A . B . A$. (i 937 ) 789 at 816,$847 ; 63$ Rep.A.B.A. (1938) 331 at 334 ; McGuire, "The American Bar Association's Administrative Law Bill," I La. L. Rev. (1939) 550; Symposium, 34 Ill. L. Rev. (1940) 641 . 
United States or the statute under which issued" would not affect the foregoing result. Nevertheless, for present comparative purposes the proposal is exceptionally noteworthy. It is not intended as a substitute for existing methods of judicial review of regulations in connection with actual controversies. ${ }^{56}$ But it provides a procedure for obtaining declaratory judgments on the validity of administrative rules. ${ }^{57}$ Since the federal constitutional courts, even under the Declaratory Judgments Act, ${ }^{58}$ could not render such judgments, except in connection with a "case or controversy," it must be assumed that the court of appeals would render such judgments in its capacity as a legislative, or let us say an administrative, court. Thus administrative rules could be annulled upon the petition of private parties in precisely the same manner in which the French Conseil d'État acts upon a recourse for excess of power. If, however, the petition fails and the rule is upheld, then it may again become subject to attack in connection with an ordinary action.

However, it should not be overlooked that there has been a tendency to incorporate more drastic provisions for the judicial review of regulations into modern statutes, of which the Food, Drug and Cosmetic Act of $1938^{60}$ is the most outstand-

${ }^{B 0}$ Sec. 3 specifically provides that "nothing contained in this section shall prevent the determination of the validity or invalidity of any rule which may be involved in any suit or review of an administrative decision or order in any court of the United States as now or hereafter authorized by law."

${ }^{87}$ S. 915, sec. 3: "The court . . . shall have no power in the proceedings except to render a declaratory judgment holding such rule legal and valid or holding it contrary to law and invalid."

${ }^{68} 48$ Stat. L. (1934) 955, 28 U. S. C. (1934) § 400.

${ }^{60}$ Muskrat v. United States, (I9I I) 2 I 9 U. S. 346; Liberty Warehouse Co. v. Grannis, (1927) 273 U. S. 70; Willing v. Chicago Auditorium Association, (1928) 277 U.S. 274.

${ }^{\circ 0} 2$ Stat. L. (r938) ro40; 2 I U. S. C. (Supp. r 939), § 30 r et seq. See "The New Food, Drug and Cosmetic Legislation," 6 Law Eo Contem. Prob. (1 939) I; Fuchs, "The Formulation and Review of Regulations under the Food, Drug and Cosmetic Act," ibid. 43. 
ing instance. Under this statute ${ }^{61}$ "any person who will be adversely affected" may obtain a review of the regulation in a United States Circuit Court of Appeals. These courts are given jurisdiction not only to "set it aside in whole or in part, temporarily or permanently," but also "if the Secretary [of Agriculture] refuses to issue, amend or repeal a regulation ... [to] order [him] to take action, with respect to such regulation, in accordance with law."62 Provisions of this type seem to run so definitely counter to heretofore accepted notions of division of labor in the departments of government that the flagrant imposition of administrative functions upon federal courts can scarcely be expected to stand the test of constitutionality. Since they have not as yet been put to that test, it is very doubtful whether they should be considered as representative of the American administrative system.

a 21 U. S. C. (Supp. 1939), § 371 (f).

- Ibid., §371 (f) (3). 


\section{Chapter VII}

\section{Jurisdiction Over Public Officers}

TURISDICTION of the ordinary French courts has been limited in regard to administrative regulations on the constitutional ground that they emanate from administrative bodies. ${ }^{1}$ As a rule ${ }^{2}$ acts of general application, even if illegal, retain their administrative immunity. So far as the judicial courts are concerned, they are not nullities until so declared by the administrative courts. Acts of individual application, ${ }^{3}$ however, have not been accorded the same treatment. In respect to these acts it has been held that certain kinds of illegality deprive them of their administrative character, notwithstanding their administrative origin, so that controversies to which they give rise must be litigated in the ordinary courts. The classic instances with which the new régime administratif had to deal were official acts which furnished the basis for actions ex delicto or quasi-ex delicto against administrative officials. The difficulties which at the outset grew out of these casés had an important bearing upon subsequent jurisdictional developments.

\footnotetext{
${ }^{1}$ Reference must again be made to the law of the 16 th Fructidor, year III (Sept. 2, I 795): "Défenses itératives sont faites aux tribunaux de connaître des actes d'administration de quelque espèce qu'ils soient. . . . "See translation, supra, chap. I, note 38 .

${ }^{2}$ Septfonds v. Chemins de fer du Midi, S. I 923.3 .49 , D. 1924.3.41, supra, chap. VI, note $4 \mathrm{I}$.

${ }^{8}$ Continental writers have frequently given specific attention to the distinction between acts of general and acts of limited application. See, e. g., Waline, "Observations sur la gradation des normes juridiques établie par $\mathbf{M}$. Carré de Malberg," 51 R. D. P. (1934) 521 at 539; Mayer, Deutsches Verwaltungsrechi, 2d ed. (1914), Vol. I, pp. 84 ff., 95 ff.; Bernatzik, Rechtsprechung und materielle Rechtskraft (1886), pp. I ff.
} 
A. THE CONDITIONS AT THE TIME OF THE FRENCH

\section{REVOLUTION}

The new regime, solicitous to ward off interference by the judiciary with administrative objectives and policies, prohibited not only judicial inquiry into administrative acts but also actions against administrative officials and agents on account of such acts. ${ }^{4}$ For it was apparent that without the second interdict the first might easily be circumvented. But even so, the problem to be solved was far too intricate to yield to these simple rules.

The new order could not hope to succeed by discarding the institutions of the ancien régime in their entirety; nor did it attempt to do so. Certain traditions. inevitably survived and served to qualify the content of the new doctrines and the meaning of the new labels. It was not difficult to oust the judicial courts from all participation in and control over administrative action. On the other hand, to prohibit those courts from assuming jurisdiction over the persons of administrative agents conflicted sharply with the fact that redress of all delictual and quasi-delictual acts was available only in the ordinary courts. This limitation was itself due to the doctrine of the differentiation of agencies, which precluded the administrative from exercising jurisdiction over strictly judicial matters. ${ }^{5}$ But it is well to bear in mind also that at the beginning the new administrative organism was not equipped with any machinery for the judicial disposition of complaints. ${ }^{6}$ The personal liability of public officers became thus at once submerged in a vexing problem of jurisdiction.

"Statutes quoted supra, chap. I, note 38.

'Art. 89, Constitution of the 5th Fructidor, year III (Aug. 22, 1795). See supra, chap. I, note 40.

- See supra, chap. I, subdivision C. 
In France, prior to and immediately following the Revolution, ${ }^{7}$ the maxim obtained that "the king can do no wrong." " Consequently suits for damages sustained on account of the acts of governmental agents could be directed only against those agents personally and had to be prosecuted in the ordinary courts. But the political background of the French system forced later developments to take a turn away from the earlier practice. In France the position of the judiciary prior to I 789 was extremely strong, although it was so in a political rather than in a constitutional sense. Prosecutions of administrative officials in the judicial courts often had political significance, and the Crown frequently found it necessary to protect itself with évocations, ${ }^{9}$ that is, by withdrawing from the courts the jurisdiction which they had assumed over the person of public officers. The revolutionary legislators therefore felt that they were confronted with a double task. Provision had to be made for the personal liability of public officials in order to provide an effective guarantee against arbitrary invasion of civil liberties. ${ }^{10}$ At the same time, it seemed necessary to protect administrative agents against mala fide actions which, as the experiences of the past taught, might indirectly impair administrative efficiency. The personal liability of public officers was originally sanctioned by article i 5 of the Bill of Rights of $1789,{ }^{11}$ and was reiterated in article 24

${ }^{7}$ Cf. Hauriou, Précis de droit administratif et de droit public, roth ed. (1921), p. 367.; Duguit, Traité de droit constitutionnel, 2d ed. (1923), Vol. 3, p. $262 \mathrm{ff}$. (also the bibliography at p. 294 ).

${ }^{8}$ Hauriou, supra, note 7 , referring to the Anglo-American conditions, suggested that this principle can survive only in countries where "the courts are pervaded with the sense of their responsibility." Cf. Duguit, Etudes de droit public (1903), Vol. 2, p. 637.

${ }^{\circ}$ Supra, pp. I1, 25 ; cf. Laferrière, Traité de la juridiction administrative et des recours contentieux, $2 \mathrm{~d}$ ed. (1896), Vol. I, p. 638, note I.

${ }^{10}$ Duguit, Traité, Vol. 3, pp. 263-264; Ducrocq, Cours de droit administratif, 7 th ed. (1897), Vol. 3, p. 330 .

11 "Sbciety has a right to demand that each public officer account for his official acts." Declaration of Rights of Aug. 26, 1789, art. 15, quoted in 
of the Bill of Rights of $\mathrm{I} 793 .{ }^{12}$ Regulation of criminal liability was effected through specific sections of the criminal code, ${ }^{13}$ while civil liability for torts was derived from the broad language of article 1382 of the civil code ${ }^{14}$ which provides that "Anything done by a person which causes damage to another obligates the person through whose fault the damage has occurred to make reparation." On the other hand, abuses of criminal prosecutions and civil actions against administrative functionaries were first sought to be checked by a statute enacted in $1790^{15}$ which required the concurrence of the hier-

- archic superior before a court could proceed to determine the personal liability of an official on account of an act done in the exercise of his official function.

\section{B. THE CONSTITUTIONAL GUARANTEE OF ADMINISTRATIVE} AGENTS OF THE YEAR VIII ${ }^{16}$

The incorporation in the constitution of the year VIII ${ }^{17}$ of the provisions of its article $75,{ }^{18}$ requiring the consent of the

Duguit, Traité, Vol. 3, p. 264; Ducrocq, Vol. 3, p. 330; Jacquelin, Les principes dominants du contentieux administratif (1899), p. 126.

${ }^{20}$ The security of society "cannot exist if the limits of the functions of the state are not clearly defined by law and if the personal liability of all functionaries is not assured.": Declaration of Rights of May 29, 1793, art. 24, quoted by Duguit, Traité, Vol. 3, p. 264.

${ }^{10}$ See Duguit, Traité, Vol. 3, p. 267.

${ }^{14}$ See Ducrocq, Vol. 3, p. 331 ; Hauriou, Précis, roth ed., p. 364.

${ }^{16}$ Law of $7-14$ October, 1790 ; see also the similar provision of the law of Dec. 14, 1789, art. 61, as to municipal officers. Laferrière, Vol. 1, p. 637; Ducrocq, Vol. 3, p. 331; Jacquelin, Principes, p. 126; Appleton, Traité élémentaire du contentieux administratif (1927), p. 20. This provision must be read together with the statutes enacting the differentiation of agencies and imposing forfeiture for nonobservance by the courts (supra, p. 1 3 ).

${ }^{16}$ De Cormenin, Droit administratif, sth ed. (1840), Vol. 2, p. $338 \mathrm{ff}$.; Laferrière, Vol. I, p. 637 ff.; Ducrocq, Vol. 3, p. 332 ff.; Jacquelin, Principes, p. 127 ff.; Hauriou, Précis, roth ed., pp. 367-368; Appleton, pp. 228-229; Berthélemy, Traité élémentaire de droit administratif, 13th ed. (1933); p. 85-86.

${ }^{17}$ 1 799-1 800 .

${ }^{18} 22$ Frimaire, Year VIII (Dec. 1 3, 1799): "Art. 75. The agents of the government, other than the ministers, may not be prosecuted on account of acts related 
Conseil d'État to prosecutions of administrative agents, did not establish a new principle. The enactment merely gave new emphasis to the necessity of protecting administrative agents and placed the power to authorize actions against them uniformly and exclusively ${ }^{19}$ in the hands of the highest administrative body. However, this article 75 became the basis of important developments which caused a great deal of dispute and discussion because of their bearing upon both the scope of the differentiation of agencies and the extent of the personal liability of administrative functionaries. Corresponding to the diverging attitudes toward the issues involved, interpretation and appraisal of the effect of article 75, which remained in force until I 870 , fluctuated considerably. ${ }^{20}$

In the case of Lefèvre-Pontalis v. Chéronnet, ${ }^{21}$ decided in I 864, the Cour de cassation held that "the guarantee of art. 75 is but the consequence of the fundamental principle of the separation of powers," and that "its only object is to insure independence of the administrative department from the judiciary and to protect, not the accused person, but the administrative act." ${ }^{22}$ However, it is quite clear that the requirement of special authorization of suits against administrative agents was motivated by other equally forceful considerations. ${ }^{23}$ At the beginning of the new regime the only remedy which a private party had to recover compensation for administratively inflicted injuries was an action against the of-

to their functions, except in pursuance of a decision of the Conseil d'Etat. In that case the action must be prosecuted in the ordinary courts."

${ }^{10}$ There were nevertheless a few, though unimportant, exceptions. See Laferrière, Vol. 1, p. 638 ; Jacquelin, Principes, p. 127.

${ }^{20}$ The life-span of the provision was somewhat of an anomalous phenomenon. Art. 75 continued to be applied as a strictly administrative rule, notwithstanding its origin as a constitutional precept and notwithstanding the fact that several succeeding constitutions had not reenacted it. Ducrocq, Vol. 3, p. 332 ; Jacquelin, Principes, p. 129; Appleton, p. 228 ; Berthélemy, Traité, p. 85, note 1. Cf. de Cormenin, Vol. 2, Appendix, pp. 99-100.

${ }^{2} \mathrm{~S}$. 1864 1 1.248.

22 In the same sense, de Cormenin, Vol. 2, p. 342.

${ }^{28}$ Berthélemy, Traité, p. 87 . 
ficial. The potential intimidation of administrative agents, who were thought to be exposed not only to personal liability but also to prosecutions tainted with personal and political motives, had to be counterbalanced by a certain amount of protection. Even without the attempted differentiation of agencies, this seemed necessary in a country where deliberate judicial interference with administration was anticipated. Likewise the placement of a protective mechanism in the hands of the highest administrative body was more effective than a mere procedural device for the guidance of the courts. The latter, Hauriou ${ }^{24}$ suggested, would have been adequate only in a country with a "stronger and a more responsible judiciary" than that of France at the time.

The amount of protection of officials from mala fide prosecutions actually afforded by article 75 can be gathered from its sanctions as well as from its practical operation. Whenever a criminal or civil action was instituted in a judicial tribunal to whose jurisdiction it normally belonged, ${ }^{25}$ the court was bound ${ }^{26}$ to exercise its jurisdiction, unless the incriminated act was "related to an administrative function" within the meaning of the constitutional provision. Whether or not this was the case the court determined for itself. ${ }^{27}$ The administrative department had no authority to assert a conflict, since there was no dispute as to jurisdiction; only its exercise was subjected to administrative consent. ${ }^{28}$ In view of these limitations, the scope of article 75 could easily be overestimated. ${ }^{29}$

${ }^{2 s}$ Précis, roth ed., p. 367 .

${ }^{25}$ Ducrocq, Vol. 3, p. 333.

${ }^{28}$ Ibid., p. 334, and cases cited.

27 Ibid., p. 338 ; Jacquelin, Principes, p. 128; Hauriou, Précis, roth ed., p. 368, note 2 .

${ }^{28}$ Ducrocq, Vol. 3, p. 337 ; Jacquelin, Principes, pp. 128-129. Art. 3 of an ordinance of June I, 1828 expressly prohibited conflicts. There was no occasion for the administrative to vindicate jurisdiction, and conversely the authorization to be given by the Conseil d'Etat did not confer jurisdiction but merely removed a procedural obstacle to its exercise. Laferrière, Vol. I, pp. 638-638.

${ }^{20}$ Cf. Ducrocq, Vol. 3, p. 338; Hauriou, Précis, roth ed., p. 368, note 2. 
Nevertheless, the provision was implemented with sanctions which rendered it far more effective than was ultimately found desirable. The law of August 16-24, I 790, ${ }^{30}$ embodying the differentiation of agencies, and also the criminal code ${ }^{31}$ provided forfeiture and civic degradation for judicial officers who deliberately interfered with matters of administration by entertaining actions and executing judgments against administrative officers. ${ }^{32}$ Furthermore, the criminal code ${ }^{33}$ imposed money fines for wilful violations of article 75 . In fact, the cases in which the courts requested authorizations from the Conseil d'État were numerous, ${ }^{34}$ and the general consensus is that the constitutional provision was "scandalously abused." 35 According to statistics for the latter part of the period which ended in 1870 , the number of authorizations by the Conseil was uniformly much lower than that of the rejections. ${ }^{36}$ This, however, contrasts sharply with the corresponding figures for the years $\mathrm{I} 808$ to $\mathrm{I} 8 \mathrm{I} 3$, when the authorizations far outnumbered refusals. ${ }^{37}$ It is in regard to this earlier period that de Cormenin spoke of the Conseil d'Etat as an advisory body "without favor and without hatred, and better suited than any other official body to protect at once

${ }^{30}$ Supra, p. 13 , note 38.

${ }^{81}$ Art. 127 (2), Code pénal.

Ducrocq, Vol. 3, p. 337.

Art. 1 29. Ducrocq, ibid.; Hauriou, Précis, r oth ed., p. 367 , note 3 .

see the tables of the Mises en jugement concluding each volume of the Recueil des arrêts du conseil for the years 1845 through 1866; see also the statistics given by De Cormenin, Vol. 2, p. 380 .

${ }^{35}$ Laferrière, Vol. 1, p. 640; Ducrocq, Vol. 3, pp. 338-39; Jèze, $26 R . D . P$. (1909) 263 , quoting from the conclusions of Commissaire du Gouvernement Tardieu in Girodet v. Morizot [D. 1 1908.3.57:3; S. 1908.3.81]; Hauriou, Précis, roth ed., p. 368; Waline, Manuel élémentaire de droit administratif (1936), p. 373 .

${ }^{3}$ See Ducrocq, Vol. 3, p. 333. It is difficult to reconcile the figures given by Jacquelin, Principes, p. 128 , for 1852 to 1864 with the data referred to by Ducrocq; the latter, however, seem to be more in accord with the tabulations in the volumes of the Recueil des arrêts (supra, note 34) for the same years.

${ }^{87}$ De Cormenin, Vol. 2, p. 380: 1227 authorizations, 305 rejections. 
the governmental agents against private vengeance, and private persons against arbitrary action of such agents."38 Later, when the situation reversed itself, proportionately the greatest number of rejections involved civil actions against administrative functionaries, ${ }^{39}$ which do not seem to have been within the purview of article 75 at the time of its enactment. ${ }^{\mathbf{4 0}}$

The gist of article 75 of the constitution of the Year VIII lies in that its operation was limited to suits on account of "acts related to [official] functions." ${ }^{41}$ The limitation, as interpreted, attained an importance far beyond the immediate occasion in so far as it rested on the fundamental distinction between faute personnelle and faute de service. Undoubtedly -bearing in mind the political environment of article 75there is some significance in the fact that the interpretations of the limiting phrase subsequently relied upon are those contained in the decisions of the judicial courts rather than in the mises en jugement of the Conseil d'État. The case most frequently referred to is Lefèvre-Pontalis v. Chéronnet, ${ }^{42} \mathrm{de}-$

33 Ibid., pp. 339-40.

${ }^{3}$ Ducrocq, Vol. 3, p. 333 ; Jacquelin, Principes, pp. $127-128$; cf. the tables in the volumes of the Recueil des arrêts covering the corresponding years.

${ }^{40}$ Jacquelin, p. I 27 ; Hauriou, Précis, roth ed., p. 368, note 2.

12 Supra, note 18.

42 S. 1864.1.248; referred to by Laferrière, Vol. 1, p. 639; Ducrocq, Vol. 3, p. 334; Jacquelin, Principes, p. I 28. Action was brought against the mayor of a town who in the course of duties performed in connection with an election had publicly slandered the plaintiff. Defendant invoked the protection of art. 75 and was upheld both at the trial and upon appeal. The Cour de cassation reversed the lower courts.

Laferrière, however, insists that the decision misconstrues the scope and intent of art. 75, because of certain language which must be taken as dictum only and not essential to the definition of acts of administrative officers which are relatifs a leurs fonctions. The court prefaced the body of its decision by terming art. 75 "a consequence of the separation of powers" (supra, at page 97) and "protecting not the inculpated person, but the administrative act."

Earlier, in the matter of Regnault [S. 1846.1.590], the same court had found art. 75 to apply because delictual acts imputed to a public weigher were "related to the function." The officer in charge of a public weighing machine, after having performed his duty at the instance of the owner of a wagon, was requested to reweigh the wagon upon the intervention of the mayor. The weigher, taking offense, refused to reweigh and accompanied his refusal with verbal abuses, threats, and assault upon the mayor. These acts, having occurred 
cided by the Cour de cassation in I 864. It held that for article 75 to be applicable "it is not sufficient that the defendant be an administrative agent, nor that the incriminated acts occur during the performance of his duties," but that "it is essential that the acts are related to the function, in other words, that they form a part of the very function with which they are identified, and of which they constitute the execution, even though a malicious one."

\section{REPEAL OF THE "ADMINISTRATIVE GUARANTEE"- INTERPRETATION-CONSEQUENCES ${ }^{43}$}

The growing unpopularity of the protection of administrative agents under article 75 of the constitution of the Year VIII manifested itself through frequent attacks upon the provision in and out of parliament. ${ }^{44}$ Ultimately, pressure from liberal factions ${ }^{45}$ resulted in an assault upon its protracted existence ${ }^{46}$ through the abrogating text of the decree of September 19, I $870 .{ }^{47}$ However, the seemingly unambigu-

upon the demand made and in connection with the refusal to perform an act within official duties, were deemed related to the function. (Laferrière, loc. cit., contrasts this decision with that in the Chéronnet case as representing the correct doctrine.)

${ }^{48}$ Laferrière, Vol. I, p. 640 ff.; Ducrocq, Vol. 3, pp. 332, 339 ff.; Jacquelin, Principes, p. I 30 ff.; Duguit, Traité, Vol. 3, p. 291 ff.; Hauriou, Précis, roth ed., p. $368 \mathrm{ff}$.; Appleton, p. 229 ff.; Berthélemy, Traité, p. 84 ff.; Waline, Manuel, p. 373 ff.

"Laferrière, Vol. I, p. 640; Ducrocq, Vol. 3, p. 332 ; Duguit; Traité, Vol. 3, pp. 290-291.

${ }^{4}$ Laferrière, loc. cit; Duguit, loc. cit.

${ }^{48}$ See note 20, supra.

${ }^{47}$ The provisional National Defense Government of 1870 , which was endowed with virtually dictatorial powers, decreed:

"Art. I. Article 75 of the constitution of the year VIII is repealed.

"Also repealed are all other provisions of general or special laws whose object is to impede actions against officers of all classes.

"Art. 2. Provision shall hereafter be made for civil penalties which in the public interest may have to be imposed upon private persons instituting illfounded actions against funtionaries."

This enactment in the form of a "decree-law" (décret-loi), subsequently ratified in national convention, had all the legislative force of an act of Parlia- 
ous death sentence of the decree served only to prove the transmigratory powers of the substance of the ill-respected article 75 .

The language of the decree was indeed broad. All laws obstructing suits against administrative officers ${ }^{48}$ were repealed. But the law of August I6-24, I 790, which contained one of the sanctions of the former "administrative guarantee," gave statutory expression to the constitutional differentiation of the judicial and administrative agencies. Whether this law, together with other statutes depending upon it, was affected by the decree was therefore of the utmost importance. It must be remembered that the ouster of the ordinary courts from jurisdiction over matters pertaining or related to public administration had never been acquiesced in unconditionally in all quarters. It is particularly interesting here to follow Jacquelin's ${ }^{50}$ defense of his thesis that the decree of 1870 repealed the differentiation of the two jurisdictions. To Jacquelin the intent of the decree was obvious. It reflected the ideas of the liberal party of the day. On September I 8, I 870 the government appointed a commission which was to examine the question of suppressing the administrative courts. A favorable report was unanimously voted. On the following day, September I 8, the law abrogating article 75 of the constitution of the Year VIII was passed. This viewpoint that the legislative intent behind the decree of 1870 was to remove any and all obstacles, with no solicitude for the maintenance of the differentiation of agencies, has at various times been forcibly defended. ${ }^{51}$ The contrary attitude received its chief

ment. Jacquelin, Principes, p. 130. Cf. Laferrière, Vol. I, p. 640; Ducrocq, Vol. 3, p. 355 .

${ }^{48}$ Ducrocq, Vol. 3, p. 353, Jacquelin, Principes, pp. 131-32; Appleton, pp. 229-30.

${ }^{40}$ Supra, chap. I, note 38 .

${ }^{50}$ P. 139.

${ }^{61}$ See Ducrocq, Vol. 3, pp. 339 ff.; 345, 351; Waline, Manuel, p. 374, referring to the conclusions of Léon Blum, who, in a 1918 case before the Conseil 
support from the argument that the absence of specific language $^{52}$ in the hastily made ${ }^{53}$ decree does not warrant the assumption that it should have such drastic consequences.

It seems natural that the judicial tribunals should have seized the opportunity to exercise once again, without restriction, their traditional jurisdiction in criminal and tort cases. The impediment of having first to ascertain whether the crime or tort was a functional rather than a personal act had been removed. It is in this sense that the Cour de cassation in 1872 interpreted the decree of 1870 in Meyère v. Rollin, ${ }^{54}$ which has become the leading case on the point. The court held that

d'Etat, undertook to deduce the intent of the framers of the decree from the preceding debates.

Hauriou (Précis, roth ed., p. 369, note), taking issue with Jacquelin, advances the argument that the latter might be correct "if the principle of [statutory] interpretation, which consists in supplementing the language of statutes by the intent of the legislature and by preparatory material, were universally accepted"; that, however, "this is not so," and "that, quite to the contrary, the principle applied in practice is that of purely objective interpretation, $i$. e., the reconciliation of the language with the situation to be regulated by the statute."

${ }^{52}$ Laferrière, Vol. 1, p. 641 .

${ }^{6}$ Berthélemy, Traité, p. 87. The reporter of the decree, in the Collection complète des lois, décrets, etc. [Duvergier, Vol. 70 (1870), p. 335, note] was apprehensive of the broad implications of the decree, which was passed at a time (war of 1870 with Germany) "when even the firmest minds did not retain desirable composure." He remarks that the National Convention would have to decide whether or not the decree should have the broad effects given to it at the time, perhaps without fully realizing the consequences. [The decree was later approved without restriction (supra, note 47 ), though no civil penalties pursuant to art. 2 of the decree were ever enacted. Ducrocq, Vol. 3, pp. 355-56; Répertoire de législation (Dalloz) Supp. (1892), Vol. 1o, p. 786.]

st D. 1872.1 .385 ; Laferrière, Vol. 1, pp. 642-643; Ducrocq, Vol. 3, p. 340; Jacquelin, Principes, p. 134; Hauriou, Précis, roth ed., pp. 368-369, note 4; Appleton, p. $23 \mathrm{I}$.

The case involved a civil action against an army general (Meyère) who had Rollin imprisoned for two weeks, without a hearing in court, after an altercation with an officer. The general contended that Rollin was a member of the mobilized forces. Rollin denied that he came under the jurisdiction of the general and recovered a judgment ordering his release as well as damages for wrongful imprisonment after the civil court found that he was not a member of the army (because previously rejected on account of physical defects). The general appealed, asserting that the civil court violated the principle of the differentiation of agencies in that it had interfered with the execution of an administrative act. 
the necessary effect of the decree was to permit the judiciary to appraise and determine the nature of the act of a government agent alleged to give rise to a civil action for damages. It was argued that if the determination of this question had to be referred to the administrative courts, this would revive, in a different form, the former protection of administrative officers. However, it is of even greater significance that the administrative Conseil d'Etat ${ }^{55}$ had already attached the same meaning to the decree of I 870 , less than a year after its promulgation, in another oft-cited case, de Cumont $\mathcal{E}^{2}$ Stoffet $v$. Engelhard. ${ }^{56}$ In the appeal Engelhard ${ }^{57}$ the Cour de cassation again held that the differentiation of the administrative and judicial agencies did not nullify the right restored to private individuals by the decree of September 19, I 870, to proceed directly against administrative officials in the civil courts in order to obtain indemnity for injuries to such individuals. Moreover, the decision pointed out that the ordinary courts could not be denied the power to appraise the facts and motives entering into the delictual acts brought before them without rendering illusory the remedy afforded. The language employed was repeated by the Cour de cassation in the matter of

* Charged at the time with the disposition of conflicts (supra, p. 26).

${ }^{56}$ D. 1872.3 .18 ( 3 d case), decided contrary to the conclusions of Laferrière. The case was referred to by the commissaire du gouvernement in the Meyère case. It is cited by Laferrière, Vol. 1, pp. 641-642; Jacquelin, Principes, p. 1 34 ; Hauriou, Précis, roth ed., p. 369, note 4. Two newspapers had been suspended for two months upon the order of a prefect, at the instance of military authorities in time of war, with approval of the Minister of the Interior. The prefect's publicly posted order set forth as grounds that the newspapers incited to civil war, that their owners were guilty of conniving with the enemy, and that they endangered their country. The publishers sued to have these statements declared defamatory and libelous and to have the judgment published at defendant's expense. See also Dune v. Engelhard, D. 1 872.3.18 (2d case).

${ }^{67}$ D. 1873.1 .291 . After the Conseil d'Etat had confirmed the jurisdiction of the civil court in de Cumont v. Engelhard (supra, note 56), the plaintiffs recovered judgment. Engelhard, the defendant prefect, appealed; but the Cour de cassation rejected the plea that the judgment violated the "separation of powers." The case is discussed in Répertoire de législation (Dalloz) Supp. ( 1888 ), Vol. 3, p. 245, and referred to by Laferrière, Vol. 1, pp. 643, 645; Jacquelin, Principes, p. 134 . 


\section{JURISDICTION OVER PUBLIC OFFICERS I05}

$P e t i t^{58}$ decided during the same year. Consequently the repeal of the "administrative guarantee" had effectively removed all obstacles to the exercise of jurisdiction by the ordinary courts in actions against administrative agents.

\section{REACTION-THE TRIBUNAL DES CONFLITS AND THE PELLETIER CASE}

The judicial interpretation of the decree of 1870 , which made a visible inroad upon the well-guarded administrative sanctum, had begun to entrench itself firmly. Suits against public officers on account of their official acts increased in number. ${ }^{59}$ Possibly the fear-or hope-that the principle of differentiation was losing vitality was well founded. However, fear and hope subsided suddenly with the advent of the Tribunal des conflits and its resolution of the conflict in the case of Pelletier v. Général de Ladmirault. ${ }^{60}$

The Tribunal des conflits was permanently established by the law of May 24, I $872 .{ }^{61} \mathrm{~A}$ year later the administrative department invoked its jurisdiction in an effort to have the judgment of a civil court in the Pelletier case set aside because of an erroneous interpretation of the decree of 1870 , and of the consequent violation of the differentiation of agencies. The Tribunal in its decision ${ }^{62}$ sustained the challenge and

${ }^{58}$ D. 1873.1 .390 ; cited in Répertoire de législation (Dalloz) Supp. (1888), Vol. 3, p. 245 ; Laferrière, Vol. 1, pp. 643, 645; Ducrocq, Vol. 3, p. 340 (see also the other cases there); Jacquelin, Principes, p. 134. The case involved an "administrative delict" of a member of a municipal council; no detailed facts are given in the decision.

${ }^{\infty}$ Laferrière, Vol. I, p. 643.

${ }^{\infty}$ S. $1874.2 .28 ; D, 1874.3 .5$.

${ }^{61}$ Supra, p. 26.

${ }^{6}$ Pelletier v. de Ladmirault, S. 1874.2 .28 ; D. 1874.3 .5 [the decision is reported as of July 30, 1873, but by many writers (Laferrière, Ducrocq, Jacquelin, Duguit, Hauriou) it is assigned to July 26,1873 ]. The relevant parts of the decision are in the following language: "Article 75, constitution of the year VIII, does not affect the prohibition addressed to the civil courts regarding cognizance of administrative acts, and refers exclusively to the 


\section{confined the operation of the decree of 1870 within limits sufficiently narrow to preserve the full force of the law of August I6-24, I790, fortified by that of the I6 Fructidor, Year III.}

prohibition to summon before them administrative functionaries on account of their functions. . . . These texts [the laws of August I 790 and Fructidor, year III, on the one hand, and article 75 of the constitution of the year VIII, on the other] established two distinct prohibitions which, although they both rest upon the principle of the separation of powers, whose exact interpretation they were intended to assure, referred to different objects and do not produce the same consequences in point of jurisdiction. The prohibition addressed to the judicial courts to take cognizance of acts of administration of whatever nature constitutes an absolute and general rule of jurisdiction designed to protect administrative acts and can be enforced by the administrative department by exercising its right to assert a conflict whenever, contrary to this prohibition, the judicial courts have assumed jurisdiction over an administrative act. The prohibition to sue the agents of the government without previous authorization, designed first of all to protect public functionaries against malicious prosecution, did not constitute a rule of jurisdiction, but created a plea in bar, placing an obstacle in the way of all suits against these agents on account of acts related to their official functions, even when the acts in question did not have an administrative character and constituted crimes or delicts subject to the jurisdiction of the ordinary courts. This plea was available only in the ordinary courts and could never occasion the assertion of a conflict on the part of the administration. The decree . . abrogating article 75 of the constitution of the year VIII, as well as all other provisions of general and special laws whose object is to hinder suits against public functionaries of all kinds, has had no other effect than to suppress the plea in bar founded on the absence of authorization with all its legal consequences, and to restore to the ordinary courts their entire freedom of action within the limits of their jurisdiction; however, it [the decree] could not have had the further effect of extending the limits of their jurisdiction, and of removing the prohibition, addressed to them in provisions other than those expressly repealed, by the decree, to take cognizance of administrative acts, and to deny in that case to the administrative authorities the right to assert conflicts. Such an interpretation could not be reconciled with the law of May 24, 1872, which, by establishing the Tribunal des conflits, sanctions anew the principle of the 'separation of powers' and the rules of jurisdiction which follow from it. Furthermore, in the case at bar it is necessary to apply the special legislation concerning the state of siege. In fact the action commenced by Pelletier . . . against Général de Ladmirault . . . intends to have the seizure (performed - . by virtue of the law concerning the state of siege) of the newspaper published by Pelletier declared arbitrary and illegal, and therefore of no force and effect, and consequently to have ordered the restitution of the copies improperly seized and to have the defendants jointly condemned to the payment of two thousand francs in damages. The prohibition and seizure of the newspaper ordered by the general as commander of the state of siege constituted a preventive police measure taken by the general as a representative of the state in the exercise and within the limits of the extraordinary powers conferred upon him by article 9, section 4 of the law of August 9, 1849, concern- 
The decision attracted widespread attention ${ }^{63}$ commensurate to its immediate and mediate import, and although it disposes of a purely jurisdictional issue, the facts upon which the original cause of action rests must be specifically noted. As in the de Cumont $\mathcal{E}$ Stofflet case, ${ }^{64}$ the plaintiff in the original action was a publisher, the first issue of whose newspaper had been confiscated upon the order of an army general in time of war. If, therefore, the civil court had the power to declare the seizure of the newspaper, illegal—as it did—so that the plaintiff might recover judgment for restitution and damages, it had necessarily power to scrutinize the propriety of the administrative act, ${ }^{65}$ the seizure itself.

In laying the foundation for its decision the Tribunal des conflits referred to the statute to which it owed its existence. $^{66}$ This law, the Tribunal held, reaffirmed the differentiation of agencies, and that doctrine consequently could

ing the state of siege, and responsibility for which rests with the government which delegated its powers to him. Plaintiff's claim rests entirely upon this exercise of police power, and, aside from this act, does not impute to defendants any personal errors of the character which would involve their personal liability; in fact the action is directed against the act itself, represented by and merged in the functionaries who caused its performance and cooperated in its execution. Upon these grounds the civil court of Senlis was incompetent to take cognizance of plaintiff's claim."

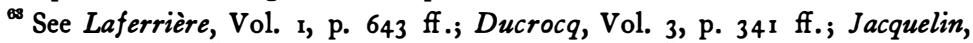
Principes, p. 134 ff.; Duguit, Traité, Vol. 3, p. 291 ff.; Jèze, $26 R$. D. P. at 264; Hauriou, Précis, roth ed., p. 368; Appleton, p. 231 ; Waline, Manuel, p. $373 \mathrm{ff}$.

64 Supra, note 56 .

${ }^{68}$ Compare the opinion of the commissaire du gouvernement, David, who contended (D. $1874 \cdot 3.6: 3$ ) that the de Cumont case (D. 1872.3 .18 , supra, note 56) was decided by the Conseil d'Etat in the opposite sense only because the civil court did not have to pass upon the validity of the administrative act in order to determine the consequences of the delictual act complained of, which could be appraised separately. Cf. Waline, Manuel, p. 374 .

${ }^{60}$ Supra, p. r 05. Jacquelin (Principes, p. I 4 I) objected that a conflict could no more be asserted by the administrative under the regime of 1870 , than formerly when art. 75 of the constitution of the year VIII was in force; for art. 3 of the ordinance of June 1,1828 , never having been repealed, still prohibited conflicts in matters of suits against administrative agents. However, it would seem that the very language of the statute precluded its operation once the system of administrative authorizations had been abolished. 
not be affected in its scope by the decree of 1870 . The latter, it found, had only abolished the "plea in bar" by which the exercise of jurisdiction normally belonging to the ordinary courts could be arrested in the absence of preliminary authorization. The decision draws a distinction between the statutes of I790 and the Year III as compared with the repealed article 75. The former were said to contain a general rule of jurisdiction intended to protect all administrative acts; the latter only afforded a procedural protection for the benefit of administrative agents. The procedural obstacle indeed had been removed, but the jurisdiction of the ordinary courts was not thereby enlarged. It was obvious that unless the abrogating decree of I 870 was construed to leave the differentiation of agencies unaffected, actions against administrative officials could be readily turned into a device for collateral attacks on administrative acts in the civil courts. To forestall this contingency ${ }^{67}$ was the unmistakable aim of the Tribunal des conflits.

The doctrine announced in the Pelletier decision became at once the law applied by all courts, ${ }^{68}$ and its significance is well reflected in the subsequent developments. The critics of

${ }^{67}$ D. $1874 \cdot 3 \cdot 5$ :3. Cf. the conclusions of the Attorney General, Reverchon, in the Meyère case (D. 1872.1 .385 at $391: 1$ ): "It [the decree of 1870 ] indisputably derogates the principle of the separation of powers, and it is not to be supposed that its authors did not sign it with full knowledge. But even if they had not realized all the consequences thereof, it would not be for the judicial authorities to pass upon its wisdom. . . . It is their duty . . . simply to assure its exact and faithful application." See also Ducrocq, Vol. 3, p. 340. But see the conclusions in the matter Valentin, cited by Laferrière, Vol. I, pp. 645-46, note 2, criticizing the Meyère decision.

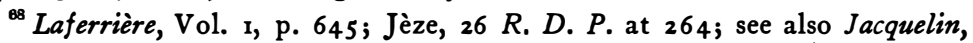
Principes, p. 134 ff.; Duguit, Traité, Vol. 3, p. 291 . The force of the decision is interesting as an indication of the great respect which the Tribunal des conflits commanded immediately following its organization.

Cf. Ducrocq, Vol. 3, p. 343, citing early cases in which, by way of distinction, the Tribunal had held the civil courts competent in actions against administrative officers because the acts attacked were deemed purely personal and not requiring inquiry into official functions (e. g., Godart v. Cliquet, D. 1 874.3.4). 
the doctrine of the Pelletier case insisted not only that it resurrected the former "administrative guarantee," but also that it replaced that guarantee with an even more effectively protective mechanism. ${ }^{69}$ Indeed, formerly the ordinary courts determined for themselves whether a cause before them required the formality of authorization by the Conseil d'État. But the new order of things apparently enabled the administrative department to withdraw from the civil courts suits against administrative agents which they had determined to be within their jursdiction. The defendant official would therefore escape personal liability whenever a conflict should be resolved against these courts; for the administrative courts have no power to hold the individual members of the active administration liable in damages. ${ }^{70}$ The argument which saw in the new system an aggravation of the evil sought to be remedied $^{71}$ apparently assumed that the Pelletier decision would encourage the administrative department to abuse its right to challenge the jurisdiction of the judicial courts, and furthermore that it would have the necessary support of the Tribunal des conflits. Had these anticipations been wellfounded, the subsequent legislative proposals to restore administrative protection as it existed prior to 1870 would have been almost certain to become law. ${ }^{72}$ However, the fears engendered by the Pelletier holding did not materialize. Even though the decree of I 870 , as finally interpreted, afforded

${ }^{6 \theta}$ Ducrocq complained that the decree of ${ }^{8} 870$ seemed to be destined to have none of the effects intended by its authors (see also p. 346).

Jacquelin, Principes, pp. 132-133, 143: “. . . it [the administrative protection] has been reestablished ... with the aid of the erroneous conception of the principle of the separation of powers."

${ }^{70}$ Jacquelin, Principes, p. 133; Waline, Manuel, p. 374.

${ }^{\pi}$ Ducrocq, Vol. 3, p. 352 ; Jacquelin, Principes, p. 133.

${ }^{72}$ Bills continued to be introduced after 1873 ; in 1879 , the principle co-author of the decree of September 19, 1 870 , introduced a draft of a law to this effect, which was favorably reported by a committee. Ducrocq, Vol. 3, pp. 343-345; Jacquelin, Principes, pp. 143-44. 
protection to administrative agents, it was a new form of protection. It was no longer administrative but judicial protection- ${ }^{73}$ protection by judicial methods. ${ }^{74}$

T3aline, Manuel, pp. 373, 375 .

"Berthélemy (Traité, p. 87) defends the doctrine of the Pelletier case on another ground: Even if it be conceded that the doctrine limits greatly-not wholly-the scope of the decree of 1870 , it is unimportant. For neither under the old nor under the new systems was the administrative officer privileged as compared with a private person. There could, $a b$ initio, be no privilege because what is protected is the functional act only. The private person, not having any official functions, needs no such protection (p. 85). The argument is valid if in each case the functional act can be and actually is distinguished, and if the machinery provided is capable of precluding abuse or even error. 


\section{Chapter VIII}

\section{Faute Personnelle and Faute de Service}

$\neg$ HE Pelletier decision was an award by the newly appointed arbiter, the Tribunal des conflits, in favor of

1 the continued unimpaired validity of the principle of the differentiation of agencies. Nevertheless, only the actual applications of the doctrine announced can throw light upon whether or not it has succeeded in barring collateral attacks upon administrative acts in the form of damage suits in the civil courts. In order to appraise the respective developments accurately, various circumstances must be taken into consideration.

Some of the anticipated effects of interpreting restrictively the act that repealed the unpopular "administrative guarantee" were checked almost at once, and one factor in particular contributed to making generally palatable the doctrine whose birth had been attended by so much skepticism. At the time of the Pelletier case an old notion was being superseded, ${ }^{2}$ and the French had definitely arrived at admitting that the king can do wrong. In other words, the principle of state liability had taken root and was being established on a broader basis as time went on until, soon after the turn of the century, it extended to all administrative acts, excepting only acts of state. ${ }^{3}$

${ }^{1}$ Laferrière, Traité de la .juridiction administrative et des recours contentieux, 2d ed. (1 896), Vol. 1, p. 646 ff.; Jèze, note, 26 R. D.P. (1903) 263 ff.; Duguit, Traité de droit constitutionnel, $2 \mathrm{~d}$ ed. (1923), Vol. 3, p. $277 \mathrm{ff}$.; Appleton, Traité élémentaire du contentieux administratif (1927), p. 232 ff., and notes, D. 1921.1.41 ff., D. 1921.1 .17 ; Hauriou, Précis de droit administratif et de droit public, 1 oth ed. (1921), p. $370 \mathrm{ff}$.; Bonnard, Précis de droit administratif (1935), p. 99 ff.; Waline, Manuel élémentaire de droit administratif (1936), p. 376 ff. (See chap. IV, note 31 , supra.)

'Hauriou, Précis, roth ed., p. 366; Duguit, Traité, Vol. 3, p. 426 ff.

Bonnard, Précis, p. 97, and cases cited there. According to the numerous adjudications, state liability seems to have been primarily based on a theory of 
With state liability complementing the administrative agent's personal liability, private persons injuriously affected by administrative action appeared to have ample protection. It mattered little what instrumentality administered the relief to which they were entitled, so long as the dispensation of relief was fair and satisfactory. Furthermore, the solvency of the state, as compared with that of the individual agent, afforded greater assurance of ultimate indemnification. Thus, what once was purely a jurisdictional issue now turned primarily into the less vexing problem of allocating liability, ${ }^{4}$ and the spectre of the differentiation of agencies withdrew into a convenient distance. Nevertheless, the two issues remained inseparably connected, and any decision fixing liability, which must always turn on the distinction between personal and service errors, inevitably and automatically determines whether an administrative or a civil court shall have jurisdiction. Consequently, the actual extent of the jurisdiction of the ordinary courts in suits against administrative officers depends upon the current definition of faute personnelle. It is important for the purpose of this investigation to demonstrate conclusively that the definitions underlying the long line of adjudications initiated by the Pelletier decision ${ }^{5}$ disclose no attempts to transform suits against officers into indirect attacks upon administrative acts by broadening the concept. Indeed, if there had been, for an instant, a breach through which judicial competence might have been extended to strictly administrative acts, that breach was wellnigh hermetically sealed by the doctrine of the Pelletier decision, aided by the evolving theory of state liability.

"fault," i. e., faulty (defective) functioning of the public services, equivalent to which is the failure to function and delay in the functioning (ibid., p. 92, and cases cited). However, the courts have gone a step farther and have recognized liability for exceptional risk in some instances (ibid., pp. 94-95).

'Hauriou, Précis, roth ed., p. 366; cf. Duguit, Traité, Vol. 3, p. 274.

${ }^{5} \mathrm{D}$. 1874.3 .5 at $7: 3$ : "Pelletier's claim is founded exclusively upon the administrative act ... [and] imputes no personal act whatever to the defendants which would involve their personal liability." 


\section{A. EARLY PERIOD-LAFERRIÈRE}

"Personal fault" and "fault in the service" are mutually exclusive concepts. The classification of official conduct as one or the other determines the liability of the individual whose apparently authorized act has caused injury to a private person. ${ }^{6}$ This acute difference in the consequences calls for accurate definitions. But in law mutually exclusive concepts are forever prone to defy inclusion in neatly divided groups. They overlap, and every disputed area means litigation and work for the courts, as well as stimulus for the minds of the theorists. The latter, in France, endeavoring to detect and fix the characteristics of faute personnelle, have time and again suggested abstractions. Repeatedly attempts have also been made to demonstrate that the abstract criteria thus proposed are the ones which have guided the courts in fixing liability in individual cases.

\section{Intent and Magnitude of Error}

The pioneer analysis of the qualities which indicate that the act of an administrative officer is personal rather than administrative is that of Laferrière. ${ }^{7}$ The matter of LaumonnierCarriol, ${ }^{8}$ in which Laferrière acted as commissaire du gouvernement, originated with an action for damages in the civil courts by a match manufacturer who sought to hold two former ministers of finance and a prefect personally liable for

- As to concurrent liability, see note 72 , infra.

${ }^{7}$ Vol. I, p. $648 \mathrm{ff}$.

${ }^{8}$ Decided by the Tribunal des conflits in 1877 , S. 1878.2 .93 , D. 1878.3 .13 . The decision is important also because it holds that the annulment of an administrative decision does not retroactively render its execution illegal. However, in this case the state was declared liable in damages subsequent to the annulment of the administrative act. The excess of power, which was found to be the ground for annulment, consisted in the attempt to circumvent expropriation proceedings in order to avoid compensation. Cf. Monpillié v. Gruet, infra, note $7 \mathrm{r}$. On the other hand, execution of an annulled decision is personal error. Duguit, Traité, Vol. 3, p. 284. 
having had plaintiff's factory closed. The Tribunal des conflits found that no acts had been alleged which pointed to personal liability so as to justify the ordinary jurisdiction. In this often cited case Laferrière suggested to the Tribunal that there could be no personal liability for the following reason: The acts complained of were administrative and not personal because they "revealed an administrative agent, a representative of the state, more or less subject to error," but they did not reveal "the human being with his weaknesses, his passions, his indiscretions." ${ }^{\prime}$ The personal nature of the act, which is the condition precedent to personal liability, manifests itself according to Laferrière either through the magnitude of the error, where it "exceeds the ordinary risks of the function," 10 or in the "bad intentions" of the administrative officer. ${ }^{11}$ In support of this proposition, Laferrière referred to the following fact situations ${ }^{12}$ which had previously come before the Tribunal des conflits and which had been held to involve personal acts: (I) defamatory utterances of a police commissioner concerning the official functions of a former magistrate ${ }^{13}$ (2) libelous statements concerning private persons contained in a prefect's letter to an under-prefect and divulged to third parties; ${ }^{14}$ (3) incriminating allusions, oral ${ }^{15}$ or inserted in the minutes of a council meeting. ${ }^{16}$ Although these verbal acts had been committed while the respective functionaries were engaged in the performance of their official functions, they could be easily distinguished from the function.

${ }^{9}$ Laferrière, Vol. I, pp. $648-649$; see the case, S. 1878.2 .93 at $94: 3$ and D. $1878.3 .13: 1$.

${ }^{10}$ Laferrière, ibid.

u Ibid.

12 Ibid.

${ }^{13}$ Catta v. Troquier, Rec. 1881.403.

${ }^{14}$ De Rubelles v. Préfet de 1'Allier, Rec. 1880.999.

${ }^{15}$ Vimont v. Préfet de la Marne, Rec. I 884.581.

${ }^{16}$ Anduze v. Maire de Chalabre, Rec. 1879.805. 
In addition, Laferrière pointed out another type of case, the classification of which, however, proved far more troublesome. This is the type of case presented by an act which obviously is quasi-delictual, if not delictual, because of the nature of its injurious consequences, and yet coincides so completely with the administrative act which constitutes the legitimate performance of a function that to judge the one would be to judge the other. In one case referred to by Laferrière, ${ }^{17}$ an administrative agency, in order to justify certain action it had taken, published a statement rectifying facts alleged in an article by the party adversely affected. In an action against the responsible official, the plaintiff claimed damages because of (inter alia) the defamatory nature of the statement so published. The Tribunal found that it was within the power of the administrative agency to publish the statement and that "no passage thereof could be separated so as to be susceptible of individual appraisal."18 Consequently, the Tribunal held the act administrative in its entirety and therefore not cognizable in the ordinary courts.

\section{Negligence}

The Tribunal des conflits in Laferrière's time, however, was far from applying a well-formulated concept of faute personnelle. This is amply illustrated by a number of decisions. Various degrees of negligence frequently appear to have been sufficient for the Tribunal to find that the nature of the acts complained of was personal: ${ }^{19}$ e.g., misdirection of a valuable letter by a carrier; ${ }^{20}$ errors in the text or delay

${ }^{17}$ Vol. 1, p. 649 ; Soleillet v. Brière de Lisle, Rec. 1882.373.

${ }^{18}$ Similarly, involving official publication of statements of facts, Viette $v$. Dalloz, Rec. 1877.1075; Bousquet v. Pougin, Rec. 1878.47; see Laferrière, Vol. 1, pp. 649-650, note 6.

${ }^{10}$ Laferrière, loc. cit.

${ }^{20}$ Bertrand v. Rimbaud, Rec. I 874.643 . 
in delivery of telegrams; ${ }^{21}$ negligent homicide resulting from the disregard of precautions by a highway engineer; ${ }^{22}$ personal injuries inflicted upon a private person by the horse of an army officer out riding but not on duty. ${ }^{23}$

\section{Abuse of Power}

The personal character of acts connected with the performance of official functions is more evident in those early decisions which involved abuses of power. Laferrière ${ }^{24}$ refers, as an illustration, to a case of mutilation by administrative officers of an election advertisement recommending candidates for election and also attacking certain members of the government. ${ }^{25}$ The mutilation, though made upon the order of the Minister of the Interior, was held to involve personal liability, since it infringed upon the statute ${ }^{26}$ by which the defacing of election advertisements was made a delict irrespective of the person by whom it was committed. The case of Réquilé v. Grignoux-Vienne, ${ }^{27}$ involving abuse of power, which the Tribunal des conflits was called upon to decide in 1879 , has often served to indicate the point at which erroneous official action may turn into personal fault. A government munitions factory had ordered that all stray dogs entering upon its premises be poisoned by throwing a poisonous substance into the courts and paths of the factory grounds. An agent employed on the premises intentionally attracted a dog and threw some of the poisonous substance to it, caus-

${ }^{21}$ No early cases involving this particular situation have been found although Laferrière (loc. cit.) uses it as an illustration; but see Sureau v. Rigaudie, D. $1907 \cdot 3.102$, Rec. 1906.196.

${ }^{23}$ Matter of Pradines, Rec. 1875.764.

23 Tubeuf v. Général du Guiny, Rec. 1893.154.

${ }^{24}$ Laferrière, Vol. 1, p. 650.

${ }^{25}$ Vincent v. Fosse, Rec. 1890.183 ; D. 1891.3 .31 .

${ }^{20}$ Art. I 7, law of July 29, 1881 .

${ }^{27}$ Rec. 1879.803 . 
ing its death. The officer was held personally liable to the owner. Classified along with the Réquilé case is that of Dézétrée v. Maire de Meslay-le-Grenet, ${ }^{28}$ where the action of a mayor was found to have been personal rather than administrative. The facts were as follows: A member of the town council on three occasions had absented himself from meetings of the council without offering a valid excuse. Under these circumstances a declaration of resignation could have been obtained by the mayor from the prefect. However, the mayor, omitting this formality, ordered the member to leave when he appeared at a subsequent meeting. This act was held to engage the mayor's personal liability.

By way of contrast, one should note the far more consequential case of Gounouilhou v. de Tracy, ${ }^{29}$ in which the administrative department, insisting upon the administrative character of the act attacked, was sustained by the Tribunal des conflits. The action from which the conflict arose was directed against a prefect by the publisher of certain periodicals. These periodicals had been stricken from the list of publications attached to the permits issued to newspaper vendors. It was held that the act of striking the names of the newspapers from the catalogue was not of itself responsible for the exclusion of these newspapers, but that the exclusion resulted from issuing licenses to vendors only upon the condition that the particular publications should not be offered for sale. In other words, the elimination of certain periodicals from the catalogue was an integral part of the act of licensing, which, if irregular in any respect, could be censured in its entirety only by the administrative courts. Plaintiff's claim, the Tribunal said, "tends to have the civil court indirectly order the prefect to reform his act by condemning him to pay dam-

\footnotetext{
${ }^{23}$ Rec. 1883.939. See Laferrière, Vol. I, p. 651 ; Ducrocq, Cours de droit administratif, 7 th ed. (1898), Vol. 3, p. 347 .

${ }^{20}$ Rec. 1877.931 ; S. 1878.2 .157 .
} 
ages for each day's delay in revoking the restrictions attached to the licenses. ${ }^{30}$ Laferrière criticized the decision ${ }^{31}$ on the ground that it was beyond the powers of the administrative to impose a condition upon newspaper vendors which, in fact, operated as a limitation of the freedom of the press. ${ }^{32}$ Viewed in this light, the act of attaching the condition to the license seemed to him an abuse of power and a faute personnelle. This view obviously was not in accord with the doctrine of the Pelletier decision, which reserved administrative policies for the scrutiny of the administrative courts exclusively. However, Laferrière's critical comments concerning the Gounouilhou case significantly anticipated a trend of thought which later became articulate. ${ }^{33}$

\section{B. CLASSIFICATIONS OF JÈZE}

From the beginning, the chief difficulty in determining the limits of personal liability presented itself when injurious acts of administrative officers appeared so intimately interwoven with the exercise of official functions that what was administrative could not be segregated from what was per-

${ }^{80}$ Rec. 1877.931 at 938 (italics added). The Tribunal's decision contains the language customarily employed since the Pelletier case, affirming that the decree of September 1 9, 1870 , had had no other effect than to suppress the plea in bar formerly available in case of actions against public officers without previous authorization, and that it did not remove the prohibition against cognizance of administrative acts by the judiciary. It held that "illegality imputed to an [otherwise] administrative act does not deprive the act of its administrative quality and does not convert it into a personal act"; and that the act complained of "cannot be separated and qualified as a distinct and independent fact which might be appraised by the judicial courts."

${ }^{31}$ Vol. 1, p. 651 , note 3.

${ }^{3}$ But compare the opinion of the commissaire du gouvernement in the case. A "law" attributed to December 25, I 875, in art. 3, provided that "prohibitions to sell and distribute in the public streets can no longer be issued by the administrative agencies as isolated measures against individual newspapers." However, the statute required applicants for licenses to submit lists of the publications they intended to sell. These lists, upon inspection, were signed by the prefect and served as license certificates.

"See infra, chap. IX, "The Doctrine of Administrative Trespass." 
sonal. Ever since, one of the primary concerns has been to trace as accurately as might be done this elusive line of demarcation.

\section{Bad Faith-Gross Error}

In a comment published in $1909^{34}$ Jèze objected to the attempts which had been made to establish inductively the line dividing faute de service from faute personnelle. Instead, Jèze proposed to deduce from the cases the considerations which had guided the courts in determining liability and jurisdiction. He found that the courts in fact had only elaborated and refined the criteria already detected by Laferrière. Obviously one of these criteria, "bad intention," Jèze pointed out, is not difficult to discover because its presence invariably manifests itself through an overt act of hostility towards the victim. ${ }^{35}$ Consequently in cases of malicious intent personal fault is not merged in but is "detached from the exercise of the function." ${ }^{\mathbf{3 6}}$ The author, on the other hand, directed attention to the apparent complication which enters into the determination of liability when the latter depends upon whether or not the error committed is great enough to "exceed the ordinary risks of the function," "to be inexcusable because of the peculiar situation of the official." ${ }^{38}$ Jèze, thus dividing personal faults into (I) faults accompanied by bad faith and (2) faults arising from gross

34 26 R. D.P. ( 1 909) 263 .

${ }^{35}$ Jèze, $26 R$. D. P. at 267 . In Grosson v. Souhet, Rec. 1902.644, the Tribunal des conflits resolved a negative conflict arising from an action for damages by a plaintiff whom the mayor had denied access to the municipal slaughter-house. See also Lalande v. Peynaud, D. I 899.3.93, Rec. 1897.758, holding a faute personnelle the act of a mayor, who, after proper publication of a corrected election list, posted a second notice and had the town crier announce that a named person had been rightfully stricken from the list because of bankruptcy.

* Jèze, loc. cit.

Ibid.

Ibid. 
error, expressed in fact what Hauriou ${ }^{39}$ later described more clearly as different degrees of "detachability." In other words, there is either a personal act clearly separable from the "mechanical or automatic" performance of the function, ${ }^{40}$ such as disconnected defamatory statements; ${ }^{41}$ or there is a distinguishable but not detachable circumstance to which the alleged injury is attributable, for instance, gross negligence in the performance of an official duty. ${ }^{42}$

\section{Fautes Lourdes}

It should be observed that the decisions cited by Jèze to illustrate fautes lourdes (grave errors) ${ }^{43}$ involving personal liability, are also instances in which the personal element of bad faith was discernible but not separable from the administrative act. Thus (a) in Gérôme v. Gerbault ${ }^{44}$ the defendant postmaster had, without proof, formally reported the theft by an employee of a folder containing postal money orders. Actually the folder had been misplaced by the postmaster himself. (b) The fault imputed to officers of the sanitary police in Mascaras v. Séné et Chichét5 consisted in an erroneous diagnosis of a young woman aboard ship, which resulted

${ }^{29}$ Précis, roth ed., pp. $371-372$.

${ }^{20}$ Ibid., p. 370.

${ }^{11}$ Lalande v. Peynaud, D. 1899.3.93, Rec. 1897.758, supra, note 35. Cf. Préfet v. Loumagne, Rec. 1 897.497; Hauriou, Précis, 1 oth ed., p. 372.

${ }^{4}$ De Rubelles v. Préfet de L'Allier, Rec. 1880.999 , supra, note 14 . But cf. the later case of Sureau v. Rigaudie (Rec. 1906.196, D. 1 907.3.102) holding the erroneous delivery of a telegram not to be a "personal fault." (Hauriou, Précis, I oth ed., p. 373, note. The other case referred to there, Bouhier v. Candelier, Rec. 1881.918 , does not seem to be in point.) Evidently it was recognized that the error, on the part of mail and telegram carriers, could not well be construed as being tainted with bad faith in the absence of direct evidence.

${ }^{43}$ Subclassified into delictual and non-delictual errors $(26 R . D . P$. at 267-268).

"Rec. 1908.501. See also Coutareau v. Gillet, D. 1913.3.1 30, S. 1914.3.51; Waline, Manuel, p. 378.

${ }^{*}$ Rec. 1 902.209 , D. 1903.3 .93$. 
in her internment in a hospital and subsequent death. In these cases the personal fault apparently consisted in "gross error in the determination of facts." ${ }^{\text {} 6}$ The decisions indicate that the error-or rather the negligence-was deemed equivalent to bad faith. ${ }^{47}$

Another group of cases tends to show that personal liability may arise from errors of law, as for example where the administrative officer is grossly mistaken as to his powers. The instances referred to in Jèze's comment ${ }^{48}$ involved the following situations: (a) A mayor, having custody of the surveymaps recorded in the city registry, gruffly prevented inspection by a taxpayer of a map already placed at his disposal by a clerk in the mayor's office. ${ }^{49}$ (b) The defendant mayor had given notice to a property owner to make repairs on a building to prevent danger to the public. ${ }^{50} \mathrm{Upon}$ failure to comply, the mayor ordered the immediate demolition of the building. Under the applicable statute ${ }^{51}$ the mayor had authority only to order provisional precautions to be taken in case of imminent danger. Destruction of a building in all cases has to be authorized by the Conseil de préfecture, and must be preceded by expert findings, notice, and opportunity for hearing.

${ }^{48}$ Jèze, $26 R$. D. $P$. at 268 . In the second case the Tribunal said, "these facts, if proved, would constitute gross errors which because of their consequences exceeded the normal exercise of the function with which the two physicians were charged." ("If proved" emphasizes the function of the Tribunal des conflits, which is not to establish the alleged facts, but merely to fix the liability and consequent jurisdiction upon the assumption that the facts are as asserted.)

${ }^{47}$ Comparable are the cases involving utterances by public school teachers in class which, e. g., are indecent, violate the principle of neutrality in matters of religion, or tend to justify the commission of crimes. Girodet v. Morizot, Rec. 1908.597, S. 1908.3.81, D. 1908.3.57, noted 25 R. D. P. (1908) 272; Jèze, $26 R$. D. P. at 269.

${ }^{28}$ Jèze, $26 R$. D. P. at 269-270.

${ }^{40}$ Uhel v. Le Visage, Maire, Rec. I 900.51; the Tribunal held that "the act [of the mayor] could not be said to be of an administrative character because of the circumstances under which it occurred." flict.)

${ }^{50}$ Maudière v. Maire et commune de Nouzon, Rec. 1904.252 (negative con-

${ }^{81}$ Law of June 21,1898 , chap. 1 , concerning the public safety, arts. 3-6. 
(c) Demolition of a wall under construction on privately owned property on the bank of a creek was ordered by a mayor, ${ }^{52}$ and effected the day following. The order was issued because of alleged public danger in case of flood. Upon complaint, the action was defended on the ground that it had been taken after due deliberation and approval by the city council, and in the belief that the wall was located upon land owned by the city. The mayor also insisted that under the circumstances he could legitimately hold himself to be acting with the implied statutory authority of the prefect. ${ }^{53}$ However, the Tribunal des conflits held that the mayor acted without proper authority, and that the impeached act, being outside his powers, was "purely personal."

In the first of the foregoing instances the personal element could well be said ${ }^{54}$ to have manifested itself in the arbitrariness of the act, amounting to an abuse of power. But in the second and third cases any intentional abuse of power had to be inferred from the grossly erroneous interpretation, if not the disregard, ${ }^{55}$ of express statutory provisions defining the mayor's powers. In the light of the reported facts these are obviously borderline cases, and it is not too difficult to imagine that under somewhat similar circumstances no personal fault might be found. It seems indeed extremely probable that the supposed malicious motives of the respective officials were not the real ground of decision. The jurisdiction of the ordinary courts could well be confirmed in these cases; but the result, as appears below, may more correctly be reached under

0s Montlaur v. Balmigère, Maire de Tournissan, Rec. 1904.888, D. 1 906.3.58.

${ }^{53}$ Art. 16 of the law of April 8, 1898 , title II, Non-navigable Water Courses: "The mayor may, with the authority of the prefect, take all measures necessary in policing water courses."

ss Jèze, $26 R$. D. P. at $270,274$.

${ }^{\infty}$ These cases should again be considered in connection with the doctrine of administrative trespass, infra, chap. IX, pp. 143 and $150 \mathrm{ff}$. 
the doctrine of trespass ${ }^{56}$ instead of by what seems a doubtful application of the faute personnelle doctrine.

Aside from the cases of non-delictual fautes lourdes, Jèze ${ }^{57}$ calls attention to two decisions ${ }^{58}$ holding that violations of statutes expressly prohibiting the acts involved constituted fautes personnelles.

The author also considers the particular situation in which an unmistakable faute personnelle has been committed upon the order or with the approval of a hierarchic superior. The general rule ${ }^{59}$ seems to be that the element of obedience does not affect the personal character of the act. In the Vincent case $^{60}$ police officers who had mutilated election posters in violation of a criminal statute were held liable notwithstanding the order of the Minister of the Interior ${ }^{61} \mathrm{~A}$ similar result was reached ${ }^{62}$ in an action against a colonial official who, upon the order of his superior, caused a native to be forcibly expelled from his hut and his property to be destroyed. Probably with greater justification, the same principle has been applied in the case of personal acts defended with the subsequent approval of a superior officer. ${ }^{63}$

${ }^{8 B}$ Infra, chap. IX.

${ }^{67} 26 R$. D. P. at 270-271.

${ }^{68}$ Vincent v. Fosse, Rec. 1890.183, D. 1891.3.31, supra, note 25 ; Girodet v. Morizot, Rec. 1 908.597 , S. 1908.3 .81 , D. 1908.3 .57 , noted 25 R. D. P. (1908) 272, supra, note 47 .

${ }^{60}$ Jèze, $26 R$. D. P. at $271-273$.

${ }^{\infty}$ Supra, note 58.

${ }^{21}$ The case is especially interesting if viewed in the light of the objections raised before the Tribunal by the Minister of the Interior. The latter directed attention to the fact that the action was brought not only against the officers who executed the order but also against the under-prefect who had transmitted it. On the other hand, the prefect who had received his instructions from the minister and had transmitted them to the under-prefect was not made a party defendant. The government suggested that this had been done in order to avoid involving the minister personally. See Waline, Manuel, pp. 379 ff., 382, concerning the virtual absence of a civil liability of the ministers.

${ }^{82}$ Mohammed-ben-Belkassem, Rec. 1891.542 , D. 1892.3 .125$.

* See Saffroy v. Martin et Ligeron, Rec. 1894.628 , D. 1896.3.10. Duguit (Traité, Vol. 3, p. $285 \mathrm{ff}$.) agrees that superior orders or approvals do not 


\section{LATER DEVELOPMENTS}

The earlier analyses of faute personnelle have been followed by various attempts to devise more accurate definitions. However, no new criteria have been discovered and in fact little has been done beyond carefully redefining the basic ingredients; that is, the personal intent and the evidentiary circumstances which must accompany the impersonal functional act.

\section{Duguit-Detachable and Nondetachable Errors}

Duguit, in his treatise on constitutional law and in a note, ${ }^{64}$ emphatically insists upon the necessity of dividing personal faults into (I) "detachable" Accordingly, in some cases the fault consists in an independent act, which, purporting to be official, is in fact personal because of obvious bad faith or malicious intent. ${ }^{87}$ In other cases, however, there is only one functional act, but this act "contains a personal element." ${ }^{88}$ The distinction emphasizes anew that personal fault can always be isolated from the official function whether the former takes the form of a separate

preclude the subordinate's personal liability; however, he thinks that these facts should operate as a mitigating circumstance [referring to Barthélemy's article, "L'influence de l'ordre hiérarchique sur la responsabilité des agents," 31 R. D. P. (1914) 491], insisting that the order of the hierarchic superior is capable "of giving administrative character to a faute personnelle," (p. 547). The classic exception to the prevailing rule is the absolute obedience due a military superior. Duguit, Traité, Vol. 3, pp. 286, 289-29o.

ot Traité, Vol. 3, p. 278 ff.; note under Monpillié v. Gruet, Maire de Bordeaux, S. I 9 1 8-1919.2.1 ff.

${ }^{65}$ Faute détachable (ibid.).

${ }^{68}$ Faute incluse (ibid.).

${ }^{67}$ Duguit, Traité, Vol. 3, pp. 280-281, cites as examples Lalande v. Peynaud, S. 1899.3 .95 , D. 1899.3 .93 , Rec. 1897.758 , supra, note 4 I ; Girodet v. Morizot, S. 1908.3.81, D. 1908.3.57, Rec. 1908.597, supra, note 47; and Carbonnel v. Sigé, S. 1912.3.33, in which the facts were similar to those in Gérôme v. Gerbault, Rec. 1908.501, supra, note 44.

${ }^{68}$ Duguit, ibid., p. 282. 
act or of a qualifying fact. Duguit, however, draws the further conclusion ${ }^{69}$ that if the fault is incluse, the ordinary courts cannot take jurisdiction. For in order to determine whether an administrative act contains a personal element, these courts would have to scrutinize the administrative act in its entirety. This, of course, would contravene the differentiation of agencies and the doctrine of the Pelletier decision. Duguit's theory has not been accepted; nor is there any indication in the decisions ${ }^{70}$ that the administrative domain has been invaded through the exercise of jurisdiction by the ordinary courts over what Duguit termed fautes incluses.

\section{Appleton-Intellectually Discernible Fault}

The decision of the Cour de cassation in Monpillie v. Gruet, Maire de Bordeaux, ${ }^{71}$ which inspired Duguit's analysis, brought forth a further attempt to circumscribe with particular care the characteristics of personal fault. Professor Appleton, commenting on the Monpillié case and a few years later on the decision of the same court in Laur v. Lemonnier, ${ }^{72}$ in principle adopted the definition according to

${ }^{80}$ Ibid., pp. 290 ff., 292-93.

${ }^{70}$ Cf. Appleton, note, D. 1921.1.41 at $42: 1$.

${ }^{\pi}$ D. 1921.1.4I, S. I918-1919.2.I. The mayor of the city of Bordeaux issued an ordinance regulating the inspection of meat imported into the city and making provision for the transportation of meat found unstamped to a central inspection place. The parties affected by the enforcement of this provision, over their objections, entered a recourse for excess of power and obtained annulment by the Conseil d'Etat because of a vice of form (Matter of Chambre syndicale, etc., Rec. 1916.243); they also prosecuted the mayor for abuse of power under arts. I 84 and I 86 of the Code pénal, and simultaneously instituted suit for damages against the city and the mayor. In both actions the judicial courts held themselves without jurisdiction and were upheld by the Cour de cassation, which found that the measures taken by the mayor "did not involve any personal fault separable from the function which could be determined by the civil courts without inquiring into the administrative act itself."

${ }^{72}$ D. 1921.1.17. The mayor of a town had authorized the installation of an outdoor rifle range. Upon being notified of the danger resulting to the public, certain precautions were taken, but proved insufficient. A passerby was seriously 
which personal fault arises from malicious intent either apparent on the face of the act or inferable from the gravity of the error ${ }^{73}$ This author also recognizes that fault, liability for which can be determined by the ordinary courts, may appear in the form of a separate act accompanying the lawful exercise of a function. However, Professor Appleton concludes from the adjudicated cases that the civil courts are competent even if the element of fault, though inseparably connected with (inclus) $)^{74}$ the functional act, can be "intellectually" or "by an operation of the mind" discerned from the latter.

Neither of the two cases annotated by Professor Appleton held that the impeached acts contained a personal element. In the Monpillie case the enforcement of a regulation by confiscating meat for the purpose of inspection was found "to have been within the exercise of administrative functions," although the procedure followed was irregular. In other words, illegal administrative enforcement is not deemed per se a faute personnelle. ${ }^{75}$ In Laur v. Lemonnier, ${ }^{76}$ no personal error was imputed to the mayor because of his failure to take adequate measures for the protection of the public. ${ }^{77}$ It seems

injured and filed suit in the Conseil d'tat for damages against the town, and in the civil court against the mayor. The latter found in favor of plaintiff but was reversed by the Cour de cassation because the act complained of "was in fact only an alleged insufficiency in the measure taken by the mayor in the exercise of his legitimate functions." (See also Compagnie d'assurances Rhin et Moselle v. Henry, D. 1 933.3.4 I; Appleton, Supp. p. 34.) The Conseil d'Etat held the town liable in damages for faute de service.

It is now recognized that faute personnelle and faute de service can exist side by side, though only one recovery is allowed. Bonnard, Précis, p. roo; Berthélemy, Traité élémentaire de droit administratif, I $3^{\text {th }}$ ed. (1933), p. 88; Appleton, note in D. 1921.1.17:1.

${ }^{3}$ Appleton's notes in D. I92 I.I.I 7 and 4 I are substantially identical with the corresponding text of his Traité élémentaire du contentieux administratif, p. $230 \mathrm{ff}$.

${ }^{7}$ Cf. Duguit, Traité, Vol. 3, p. 281 , supra, note 67.

TApleton, note, D. I 921.1 .41 at $42: 2$, and Traité, p. 243. See supra, note 7 I.

${ }^{76} \mathrm{D}$. 1921.1 .17 , discussed by Appleton in a footnote to the case and in his Traité, pp. $235,238$.

${ }^{\boldsymbol{7}}$ See note ${ }^{2}$, supra. 
therefore that, regardless of the magnitude of the consequences, misfeasance does not result in personal liability if it is due to an error in judgment rather than to gross negligence. ${ }^{78}$ These were indeed the immediate implications of each of the two decisions. But, as Appleton points out, ${ }^{79}$ it is far more important to observe the new trend evidenced by a growing disinclination on the part of the courts to hold administrative officers personally liable unless the injurious acts were clearly accompanied by personal motives.

\section{Recent Decisions}

The marked shift of emphasis in the direction of the subjective element ${ }^{80}$ of bad faith or malicious intent is illustrated by several recent decisions. The Cour de cassation found personal fault in the refusal of an army physician to care for a soldier who insisted on two successive days that he was ill. The soldier died during the imprisonment ordered by the medical officer on the ground that the soldier was an alcoholic. ${ }^{81}$ But in another instance an army physician was held by the same court not to be personally liable, although the death of a soldier occurred as a result of questionable diagnosis and treatment. ${ }^{82}$ The Tribunal des conflits ${ }^{83}$ affirmed the jurisdiction of a civil court on the ground that the following state of facts, if proved, would involve a faute personnelle because of obviously malicious intent. The prefect against whom the action was brought had issued a pass (carte

T3 Appleton, note, D. 192 I.I.I 7 at 18 and Traité, pp. 235, 238.

T Appleton, note, D. 1921.1.1 7-1 8 and Traité, pp. 234-236. Cf. the early case in which an error in the delivery of a telegram was not treated as personal to the administrative agent. Sureau v. Rigaudie, D. 1 907.3.3.102, Rec. 1906.196.

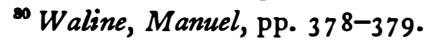

su Fontenas v. B. ... , Gaz. Pal. 1923.2.319; Appleton, Traité, p. 244.

${ }^{8}$ Chiron v. Sineau, D. H. $1926.8 \mathrm{I}$; Appleton, Traité, p. 244.

In Matter of Navarro et Mounier, D. H. 1926.55. See Appleton, Traité, p. 245 ; Waline, Manuel, p. 378. 
d'invalidité) to a disabled veteran. The latter was purposely led to believe that the pass entitled him to free railway transportation. Upon the express order of the prefect the veteran was apprehended the first time he sought to make use of the pass for that purpose, and was charged with the violation of railway regulations.

In another instance the infliction by police officers of personal injuries ("third degree") upon a prisoner while in custody at the police station was held to be a personal fault. ${ }^{84}$ This case should be contrasted with a singularly illustrative set of circumstances in which the Tribunal des conflits declined to find personal fault notwithstanding very grave consequences. ${ }^{8 \overline{5}}$ An intoxicated person was arrested and detained at police headquarters. Without being searched he was locked into a room which he set on fire with matches he carried on himself. Due to the disorderly state of the room the fire spread, and the inebriate burned to death in consequence of delay on the part of the fire department. ${ }^{86}$

The tendency of the courts to recognize only malicious intent or bad faith as indicative of personal fault, and to ex-

${ }^{84}$ Immarigeon v. Perrin, (Confl.) Rec. 1922.185; Appleton, Traité, p. 245.

${ }^{85}$ Dionnet et Proton v. l'État, (1913) S. 1920.3.47. See Waline, Manuel, pp. 377-378. See also the other cases cited there (Thomas v. Ruaux, Rec. 1 928.871; Claire v. Jamot et Loison, Rec. 1 929.389).

${ }^{80}$ In this connection, compare Gérôme v. Gerbault, Rec. 1908.501 and Coutareau v. Gillet, D. I913.3.130, S. 1914.3.51 (cited Waline, Manuel, p. 378 , supra, note 44 ), involving negligent accusations of subordinate officers.

See also Mayer v. Kraencker (D. H. 1934.398; Appleton, Traité, Supp., p. 33), where the Cour de cassation affirmed a decision of the Cour d'appel de Paris (which had reversed the trial court) answering in the negative the question whether the injury caused by the driver of a fire-truck through a collision at a street intersection resulted from personal fault. $\mathrm{Cf}$. two recent cases decided by the Cour d'appel de Paris (Béguin v. Choquet and Schmitz v. Cabanel, Gaz. Pal. 1 935.2.257, 52 R. D. P. 8 I I ). In the first, unintentional disregard of traffic regulations by petty military officers in the course of a driving lesson, resulting in bodily injury to a third person, was held not to involve a fault which was "distinct from the exercise of [their] official function." [Similar, Thépaz v. Mirabel, (Confl.) Gaz. Pal. 1935.2.261.] On the other hand, in the second case, the fact that a police officer on duty was driving at an excessive speed and on the left side of the road was found to be a faute personnelle in respect to the resulting collision and injuries. 
clude from consideration the seriousness of the injury, is well exemplified by Duez v. Fournier, ${ }^{87}$ a late decision of the Cour d'appel of Douai. This case involved a tort action against an employee of the bridge and highway department who in criminal court had been found guilty of negligent homicide. A child engaged with others in play had received fatal injuries through contact with machinery operated by the defendant. The record disclosed that the employee had repeatedly, and immediately before the accident, forbidden the children of the neighborhood to come on the premises where work was in progress. The court held that the act causing the death coincided with the lawful performance of an administrative function and that the civil liability therefore accrued to the state. ${ }^{88}$ The decision of another appellate court, in Fournier v. Bonnefond, ${ }^{89}$ was felt to be inconsistent with the holding in Duez v. Fournier because of the supposed similarity in the facts of the two cases. In the Bonnefond case a public school teacher had injured the eye of a pupil with her fountain pen. The court found that the abrupt gesture of the defendant which had caused the harm was "a fact completely apart from the acts which constituted the exercise of her public functions," and that the fault therefore was imputable to her personally. However, differences in the circumstances attending the two cases ${ }^{90}$ may account for the seemingly conflicting solutions. The act which caused the death of the child in the Duez case coincided completely with the regular,

\footnotetext{
${ }^{87}$ D. 1936.2.51, 53 R.D.P. (1936) 685; contrasted in 54 R.D.P. (1937) I 54 .

${ }_{88}^{8}$ Waline, in a note accompanying the decision (D. 1936.2.5 I, 53 R. D. P. $685)$, criticizes the result and suggests that criminal negligence necessarily involves personal fault. Cf. $52 R$. D.P. (1935) 8 10.
}

${ }^{\infty}$ D. H. 1936.502 .

${ }^{20}$ See 54 R. D. P. (1937) 1 53-154. The decision in part reads: “. . . one can indeed not accept as admissible the explanation given by [the defendant] concerning the happening of the accident, because a fountain pen simply gliding from the hand of the person using it could not ... penetrate the eye of a child standing in the vicinity of the [teacher's] desk. ... In fact the [her own] statements disclose that she turned around abruptly." D. H. 1936.502 at 503 . 
though negligent, exercise of the function, viz., the operation of the machinery by the engineer in charge. On the other hand, the abrupt movement of the teacher which injured the pupil was an independent act obviously calculated to have a disclipinary effect. Furthermore, the different relationships between the administrative agent and the victim may also have influenced the result. ${ }^{91}$

In terminating this perusal of the more recent adjudications, a somewhat unusual case should be considered in which the Cour de cassation ${ }^{92}$ declined to find personal fault in the inaction of a mayor who had failed to notify an inhabitant of the granting of a petition by the town council. The court held that this omission, which resulted in pecuniary damage to the plaintiff, was an "act inseparable from the [mayor's] function," and therefore not reviewable by a civil court.

\section{CONCLUSION}

In the light of the adjudicated cases, it is quite clear that there has been no inclination to inflate the faute personnelle concept for jurisdictional purposes. It is true that legal writers at various times have attempted to read new criteria into the decisions. Moreover, the courts may have refrained from indicating the exact contours within which they would confine the doctrine.$^{93}$ But it is equally true that the courts have never deviated from the base line of culpable intent, but have rather in the course of time kept closer to it. In the main they

${ }^{02}$ Cf. Lemaire v. Préfet du Nord, Gaz. Pal. 1937.1.396, 54 R. D. P. (1937) 381 , where a municipal hospital attendant in immediate charge of a patient was held personally liable on the ground of gross negligence.

${ }^{02}$ Saint-Martin v. Gaussorgues, Gaz. Pal. 1938.184, 55 R. D. P. (1938) I 68. An inhabitant had petitioned the town council to make certain improvements. The petition was granted, but the mayor merely summoned the petitioner to appear before the public work commission without informing him of the favorable action of the council. This, the complainant insisted, caused him to abandon the matter.

${ }^{\infty}$ See Waline, Manuel, p. 377. 
seem to hold that an in jurious act is personal to the administrative official when "the function has served his personal ends," but not when "in committing an error he believes himself to be performing his official function." ${ }^{\text {"94 }}$ To the essential requirement of abuse of power, gross negligence in the lawful exercise of power has at times been assimilated.

The jurisdiction of the civil courts over the persons of administrative officers has thus been limited to cases involving official activity which is faulty not because of intrinsic illegality but because of the presence of an independent, nonadministrative element. The phrase that a fault to be personal must be "distinguishable and separable from the administrative act and from the exercise of the function," though stereotyped, is a clear affirmation of the sanctity of strictly administrative action under the differentiation of agencies.

Upon reviewing the major steps in the jurisdictional developments connected with official tort liability in French law, the capital importance of one fact moves to the foreground. Ordinary court review of administrative action through the medium of damage suits against officers did not materialize. The repeal in 1870 , of the former "administrative guarantee" had indeed opened the door to this form of collateral attack so well-known in American law. ${ }^{95}$ But to sacrifice ad-

Berthélemy, Traité, p. 82, quoted by Appleton, note, D. 1921.1.17:2, and Traité, p. 234.

${ }^{\text {QS }}$ Collateral attacks upon administrative acts through damage suits against officials are unobstructed and common in American administrative law, and the jurisdictional complications of the French systems have been unknown in the United States. But also an ideal combination of state liability with personal liability of administrative officers is far from having been achieved. On the subject of personal liability, see Jennings, "Tort Liability of Administrative Officers," 2 I Minn. L. Rev. (1936) 263. Nevertheless, the inherent weaknesses of the principle of unmitigated personal liability are too obvious not to have been recognized.

Federal law offers an interesting example of retaining personal liability as a matter of preserving obsolete form. In the case of taxes wrongfully collected, recovery must be sought in a suit against the collector personally. The taxpayer's remedy against the collector, of common-law origin [White v. Hopkins, (C. C. A. 5th, 1931) 5I F. (2d) I 59 at 161] and "equitable in its nature and 
ministrative autonomy so lightly would scarcely have been consonant with the history and spirit of the droit administratif, and close adherence to a restrictive interpretation of the statutory language which seemed to defy the differentiation of agencies effectively preserved the status quo.

However, the conclusion is inevitable that the judicial construction of the decree of 1870 , which thus prevented a redistribution of jurisdiction, materially prompted the evolution of another phase of the French administrative system.

grounds" [Hartwell Mills v. Rose, (C. C. A. 5th, 1932) 6r F. (2d) 441 at 443] has been appropriately called an "anomalous relic of bygone modes of thought," particularly where the officer "was acting in the line of duty." Justice Cardozo in George Moore Ice Cream Co. v. Rose, (r933) 289 U. S. 373 at 382 . In fact, execution on a judgment against the collector or other revenue officer for money paid into the treasury cannot issue if there has been probable cause for the act or if the collection has been made under the directions of a superior officer. 28 U. S. C. (1934), $\$ 842$. In either case the officer under the statute is entitled to a certificate from the court. The effect of a certificate of probable cause or of direction of a superior officer is to convert the suit against the collector into a suit against the government. United States v. Sherman, ( 1878 ) 98 U. S. 565 ; George Moore Ice Cream Co. v. Rose, supra. 


\section{Chapter IX}

\section{The Doctrine of Administrative Trespass}

A. IS THERE AN INHERENT JUDICIAL POWER TO PROTECT PERSONS AND PROPERTY AGAINST ADMINISTRATIVE ENCROACHMENTS?

7 HE question whether judicial power necessarily implies power to protect persons and property against

1 administrative encroachments can be evaded in the United States by pointing to the Constitution, under which the courts have successfully asserted the power to review administrative acts. This power of the courts is commonly based upon the postulate of the "supremacy of law" and the requirement of "due process of law." But more precise answers to the suggested question may be found in the motives which lie behind the express and implied constitutional guarantees. Penetrating legal analysis has arrived at the conclusion that "legislation and administration, representing the force of collectivism, clash to some extent with the courts, representing the interest of property owners: and the 'rule of law' takes on a deeper significance." Moreover, the Supreme Court itself points to its protective mission, reminding that "when fundamental rights are in question this Court has repeatedly emphasized 'the difference in security of judicial over administrative action." " 2

However, the different conception of the separation of powers with its companion doctrine of differentiated agencies might well be understood to have obviated the performance of an analogous function by the judiciary of France. It is

${ }^{1}$ Fuchs, "Concepts and Policies in Anglo-American Administrative Law Theory," 47 Yale L. J. (1938) 538 at 559.

${ }^{2}$ Crowell v. Benson, (1932) 285 U. S. 22 at 61. 
therefore of vital importance to observe the doctrine of ordinary court protection of civil rights and property which has been unceasingly defended in the face of the postulate of administrative freedom from judicial interference. In the words of Dareste, "If the principle of the 'separation of powers' were pushed to its extreme . . . all rights and liberties of the people would be remitted to the administrative. . . . This was indeed the theory of the revolutionary period; however, it soon became undermined and the entire doctrinal development of the last hundred years is but the history of the conflict between the 'separation of powers' and the equally essential principle which places the rights and liberties of the people under the safeguard of the judiciary." But the theory that declares the administrative courts utterly incompetent and postulates the ordinary jurisdiction ${ }^{4}$ for the redress of all administrative invasions of "private constitutional rights" has at times been subject to dispute. Little or no light has been thrown on the origin of the doctrine by any of the conflicting authorities. Its validity has been assailed with considerable force by Jacquelin, ${ }^{5}$ who denied that it had any influence upon the distribution of jurisdiction between the two sets of courts. On the other hand, a ma jority of the writers who have discussed the subject are unequivocally committed to the contrary view. ${ }^{6}$ Their statements of the principle, gen-

${ }^{8}$ Les voies de recours contre les actes de la puissance publique (1 914 ), p. I 76, note 2 (italics supplied).

'In the absence of statutory provisions to the contrary.

${ }^{5}$ Les principes dominants $d u$ contentieux administratif (1899), pp. $82 \mathrm{ff}$., $97 \mathrm{ff}$., $106 \mathrm{ff}$. At the last page, it is stated: "The foregoing investigations with a view to discovering a general and directive principle have been fruitless, and this failure confirms the observation .... that the distribution of jurisdiction [among the administrative and judicial courts] has been altogether arbitrary. . . ."

'Ducrocq, Cours de droit administratif, 7th ed. (1 897), Vol. 2, p. I 3: "The judicial courts are the guardians of the right of property, and of the security, freedom and status of persons."

Aucoc, Conférences sur l'administration et le droit administratif, $3 \mathrm{~d}$ ed. (1885), Vol. 1, p. 482: “. . . the judicial courts alone may adjudicate, even 
erally broad and categorical, have a counterpart in many of the decisions of the courts. ${ }^{7}$ At the same time the adjudication of personal and property rights affected by administrative action has in many instances been reserved for the ordinary courts by express statutory provisions. ${ }^{8}$ Therefore, in order to determine whether the jurisdiction of the ordinary courts over questions of status, civil liberties and property rights must be considered as original and as having been confirmed rather than made the exception by the various statutes, other factors have to be taken into consideration. But even such

adversely to the administrative department, questions relating to the civil status and the domicile of persons, to property rights [and] to servitudes founded on rules of private law."

Laferrière, Traité de la juridiction administrative et des recours contentieux, 2d ed. (1896), Vol. I, p. 514: "The civil personality of each member of society . . . is placed under the exclusive protection of the judicial courts." Ibid., p. 529: "Aside from the civil rights properly so called, there are individual rights, legal faculties attached to each person, which are more or less broadly recognized by the constitution and by political laws. Such are: the individual freedom, the freedom of the press, the freedom of work and of industry, the right to associate [and] the right to assemble. The controversies which may arise from the exercise of these rights, in principle, come within the jurisdiction of the ordinary courts; it is before them that redress for illegal encroachments, be it by third persons or by the administration itself, must be sought."

Dareste, p. 247: “. . . the ordinary courts . . . are the natural guardians of the rights of property, of individual freedom and of the rights attached to the person." See also p. 272.

Appleton, Traité élémentaire du contentieux administratif (1927), p. 140: "It is generally recognized that the judicial courts alone are competent to adjudicate questions of status, civil capacity, domicile, violations of individual liberty and other similar rights immediately connected with the exercise of the liberties guaranteed to the individual by the constitution." Ibid., p. 152: "The courts have affirmed ever so of ten that the judiciary are the natural guardians of private property."

Cf. Moreau, Lé règlement administratif (1902), p. 260; Duguit, Traité de droit constitutionnel, 2d ed. (1923), Vol. 3, p. 30; Bonnard, Précis de droit administratif (1935), p. 158; Waline, Manuel élémentaire de droit administratif (1936), p. 52.

Tee the cases in the Répertoire de législation (Dalloz) (1848), Vol. ro, p. 472 , No. 138 et seq.; Supp. (1888), Vol. 3, p. 266, No. 209 et seq. Also see the cases noted in the digests to each volume of Dalloz, Recueil Périodique, under "Compétence Administrative."

${ }^{8}$ Aucoc, Vol. I, p. 481 ff.; Jacquelin, Principes, p. 97 ff.; Répertoire général alphabétique du droit français (1894), Vol. 12, p. 639, No. 759; Appleton, p. $140 \mathrm{ff}$. 
sources as legislative history and annotations accompanying some of the recorded statutes afford no conclusive test. ${ }^{9}$ However, a recent legislative enactment of February $7,1933{ }^{10}$ sanctioning the exclusive jurisdiction of the ordinary courts in all matters of personal liberty, is of considerable interest in this connection. This law expressly prohibits the administrative department from claiming jurisdiction over such matters in the Tribunal des conflits, even though acts of administrative agents may be involved. The discussion of the motives for the enactment ${ }^{11}$ makes especial reference to the judicial declarations that the ordinary courts are les gardiens naturels de la liberté individuelle. ${ }^{12}$ It is also of interest that the Conseil d'Etat at various times has acknowledged the purely declaratory nature of related statutory provisions by holding them to be but individual applications of a general principle. ${ }^{13}$

The writers who deny that the protection of private rights is peculiarly a matter for the civil courts insist that the juris-

' See, for example, Duvergier, Collection complète des lois, décrets, etc., Vol. 33, p. 214 , note 2. In connection with the law of June 22, 1833 , regulating the organization of the Conseils généraux de département and the Conseils d'arrondissement - both administrative bodies-it was argued that these elective bodies on general principles must be the judges of the validity of elections held for their formation; "however, they [certain members of the legislature] consented to make an exception to this rule, and to leave to adjudication by the ordinary courts questions relative to the eligibility [civil capacity] of the respective persons, because these questions, of a totally judicial nature, require special knowledge which the council members might lack." [Italics added.]

But compare the utterances made in the debates concerning the law of June 30, 1838 , regulating the care of the insane. Duvergier, Vol. 38, p. 491 at 512-513. Art. 29 of the statute makes provision for judicial inquiry into the legality of the detention of a person in an insane asylum under a decree of the administrative agencies. In regard to this statute it was said that "in the matter of personal liberty there is and can be but one recourse, that is, to the country's judiciary (la justice du pays), because it alone offers a genuine guarantee."

${ }^{10}$ Art. 2 of the act amending the Code d'Instruction Criminelle.

${ }^{11}$ D. 1933.4 .66 at 67 , note II.

${ }^{12} \mathrm{Cf}$. the opinion of the commissaire du gouvernment in L'Action française v. Bonnefoy-Sibour, D. 1935.3 .25 at 28 , discussed infra, chap. X, at note 1 .

${ }^{18}$ See Jacquelin, Principes, p. 100 ; Dareste, pp. 247-248, note 2 ; decision of the Conseil d'Etat in the matter of Clouet, Rec. 1844.493-94 (question of loss of citizenship). 
diction of the administrative courts is paramount and can be limited only by express statutory exceptions. As Béquet remarks, ${ }^{14}$ "jurisdiction depends upon the nature of the act under attack, and not upon the nature of the right in whose name action is brought." Further objections to the prevailing doctrine have been made upon the ground that there is no valid reason for discriminating between different private rights by not according all private rights the same protection. ${ }^{15}$

However well taken the objections may be, and however numerous the statutory exceptions to the rule, the predominantly affirmative attitude of the authorities must at least be recognized as strong evidence of what the Germans would term a Rechtsiiberzeugung; i. e., an innate belief pervading legal thought that the rights and liberties of the individual are more safely guarded in the hands of the judiciary than in those of administrative agencies. That this conviction among the French closely parallels the conception of the function of the courts in the United States can hardly be open to doubt.

\section{B. THE TRESPASS CONCEPT}

Prerevolutionary conditions in France called into being a jealously guarded differentiation of the administrative from the judicial agencies. For a time political bias obscured other

\footnotetext{
${ }^{14}$ Répertoire général alphabétique du droit français (1894), Vol. 12, p. 638, No. 752, citing Béquet, Contentieux administratif.

${ }^{15}$ Ibid., p. 639, No. 759; Jacquelin, Principes, p. 98. Hauriou, Précis de droit administratif et de droit public, 1 oth ed. (1921), p. 38, note 1, 1 2th ed., (1933), p. 30, note ro admits the principle of judicial competence in regard to invasions of property rights amounting to a total dispossession (cf. ibid., I oth ed., pp. 876-77, note, I 2 th ed., p. 347), but denies its validity as to encroachments upon other private rights.

Cf. the note by Alibert under the Mélinette decision, S. 1 933.3.97, 51 R. D. P. (1934) 140 at 142, criticizing the decision because it was inspired by "the false and stereotyped" precept that the judicial courts are the guardians of personal rights and public liberties.
} 
vital issues. But as the reasons for this attitude, and consequently the prejudice itself, began to disappear, interest in the normal scope of judicial authority revived. It was a natural course of events that evolved a means of bridging the gap between the competing principles of differentiation of agencies and of ordinary court protection of personal liberty and of property. Gradually, this means took shape in the form of the doctrine of administrative trespass-voie de fait. ${ }^{16}$

\section{General Theoretical Considerations}

\section{(a) Illegality}

The act of an administrative officer, though performed in the exercise of his official functions, may be purely personal and therefore beyond the confines of the administrative jurisdiction. ${ }^{17}$ Similarly, acts of administrative officials or agencies may be devoid of intrinsic legality to a degree which reduces their administrative content to the bare fact of their origin within the administrative department. If such is the case, according to the doctrine accepted in France, the department disclaims the act as nonadministrative, unless it is of a general regulatory nature. ${ }^{18}$ Jurisdiction may then be exercised by the ordinary courts without contravening the constitutional prohibition against their taking cognizance of, and interfering with, administrative operations.

As a rule, according to Laferrière's time-honored formula, ${ }^{19}$ which continues to hold sway, illegality ${ }^{20}$ does not de-

16 "Administrative trespass" or "trespass" will be used interchangeably with the French term, voie de fait, throughout this discussion.

${ }^{17}$ Supra, chaps. VII and VIII.

${ }^{18}$ See supra, chap. VI.

${ }^{19}$ Vol. I, pp. 478-8o, quoted by Dareste, p. 168. Cf. Appleton, p. $103 \mathrm{ff}$.

${ }^{20}$ See Duguit, Traité, Vol. 3, p. 681 ff.; Hauriou, Précis, roth ed., p. $52 \mathrm{ff.,}$ I 2th ed., p. 577 ff.; cf. Waline, Manuel, p. 97 ff., 300, 323. Cf. the declaration of rights of May 29, 1793, art. 24, supra, chap. VII, note 12 ; Duguit, Traité, 
prive an action of its administrative quality ${ }^{21}$ so as to bring it automatically within the jurisdiction of the ordinary courts. ${ }^{22}$ To this extent the analogy between general regulations and individual administrative acts is complete; both must be respected by the judicial courts and any infirmity in one or the other only "affects its validity, not its nature."23 The rule, however, is subject to qualification in regard to acts of only individual application.

\section{(b) Usurpation of Power}

Individual administrative acts, in theory and practice, have always been recognized as being susceptible of varying degrees of illegality; as a result illegality has been deemed capable of assuming proportions that will destroy the administrative quality of the affected act. Such a high degree of illegality is, according to Laferrière, ${ }^{24}$ present whenever an administrative agency steps not merely outside the sphere of its own competence but beyond the domain constitutionally occupied by the aggregate of administrative authority. ${ }^{25}$ Any act illegal within

Vol. 3, p. 264. See the comparative study of the question by Andersen, Ungültige Verwaltungsakte (1927), p. $293 \mathrm{ff}$.

${ }^{21}$ "Just as illegality or vice of form attending the decision of a judicial tribunal . . . does not destroy its judicial character." Laferrière, Vol. I, p. 478 .

${ }^{22}$ Laferrière, of course, had reference exclusively to actes de puissance publique, since according to his theory (see p. 40, supra), all actes de gestion in principle, come under the jurisdiction of the ordinary courts. This, however, does not affect the validity of the doctrine in question but merely calls for the logically necessary extension of its application to all acts which according to modern prevailing theory have been beyond the reach of judicial scrutiny, viz., all acts-whether authoritative or managerial-pertaining to public service. Supra, p. $4 \mathrm{I}$.

${ }^{28}$ Laferrière, ibid., p. 478.

${ }^{2 t}$ Ibid., p. 479.

${ }^{20}$ Cf. Duguit, Traité, Vol. 3, pp. 714-15; Dareste, pp. 262-265, citing Commune de Corbon v. Valet, D. $1877 . r .9$. Cf. the language used by the commissaire du gouvernement in Société immobilière de Saint-Just v. Préfet du Rhône, (discussed infra, chap. $X$, at note 24), D. 1903.3.4I, S. 1904.3 .17 at 
this definition constitutes a usurpation of power. ${ }^{26}$ In turn, the resultant lack of administrative quality produces consequences whose nature differs according to whether the act bears the semblance of a decision or order, ${ }^{27}$ or of an act performed in the execution of such an order. ${ }^{28}$ In the former case the purported decision is simply nonexistent, while in the latter the effects actually produced by the act of execution call for active redress.

The "nonexistent act" by its very term implies that it is without any effect whatever, so that it may be completely disregarded. ${ }^{30}$ Not being administrative and having no legal consequences, it is evident that it gives rise to no jurisdictional problem. $^{\mathbf{3 1}}$

On the other hand, when usurped power not only is transformed into an executory determination but manifests it-

20:2: "Employing the customary legal terminology, it is not merely contended that [the administrative agency] exceeded 'the limits of its powers,' but that it did not act in 'the exercise' of its powers, and that it left 'the domain legally assigned to it.'"

${ }^{23}$ Laferrière, Vol. 2, pp. 497-499; Duguit, Traité, Vol. 3, pp. 709, 713 ff., Vol. 2, pp. 294-95; Appleton, pp. 103-105, p. 593 ff.; Bonnard, p. 217.

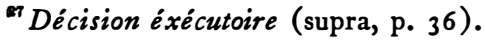

${ }^{28}$ Opération matérielle d'éxécution. Concerning the classification of this type of act, and its relation to other forms of administrative action, cf. Kormann, System der rechtsgeschäftlichen Staatsakte (1910), p. 13 ff.; Jellinek, Verwaltungsrecht, 2d ed. (1929), pp. $237 \mathrm{ff}$.

${ }^{20}$ Laferrière, Vol. 2, p. 498, Vol. 1, p. 480; Dareste, pp. 153-1 55 , and cases there cited; Duguit, Traité, Vol. 3, p. 714 ; Hauriou, Précis, roth ed., p. 39; Bonnard, Précis, p. 195; Waline, Manuel, pp. 442-44, and cases there cited. See also the recent note by Blaevoet in D. 1938.1.106 (concerning four decisions of the Cour de cassation). Blaevoet defends the theory of actes administratifs inexistants and rejects the criticism of the doctrine by Professor Mestre (S. 1935.3.57). Blaevoet likens the nonexistence of an administrative act to its unconstitutionality (D. 1938.1.106 at 110:1).

${ }^{80}$ Laferrière, Vol. 2, p. 498 ; Jèze, Les principes généraux du droit administratif, 3d ed. (1925), p. 76 ff.; Bonnard, Précis, p. 195; Hauriou, Précis, r oth ed., p. 39 .

${ }^{a}$ Because of the usurpation of power, such an act distinguishes itself from an act which is illegal because of an excess of power. See Duguit, Traité, Vol 3, pp. 714-717; Hauriou, Précis, roth ed., p. 39; cf. the note under Labadié v. Gaillardon, D. I 876.1.289:2. The latter persists until annulled by the administrative jurisdiction. The nonexistent act need not (Laferrière, Vol. 2, p. 498; Appleton, p. 594) and, in fact, cannot, be annulled (Bonnard, Précis, p. 195). 
self through immediate and tangible results relative to the rights of the individual, then the situation necessitates action to offset the illegal effects. ${ }^{32}$ In such cases it is no longer possible to speak of a "nonexisting act,"33 and under a system which postulates the differentiation of the administrative and judicial agencies the question of jurisdiction over the situation which arises must be dealt with. ${ }^{34}$ In fact, acts of this kind; due to their flagrant illegality, have been deemed to be nonadministrative, so that the responsible administrative agency is concerned neither with the act itself nor with its consequences. This construction automatically leaves the ordinary courts competent to grant relief whenever private rights have been thus invaded, without violating the principle of differentiated agencies.

\section{Administrative Trespass Defined}

Illegality resulting from usurpation of power and the directly following violation of private rights are the basic elements which have been held to convert acts performed by administrative agents into trespasses. ${ }^{35}$

However, more recently the Conseil d'Etat has shown a tendency to allow a recourse for excess of power if not for the purpose of annulling, at least in order to censure the administration active for acting illegally. See Appleton, p. 596, Bonnard, Précis, p. 195, and the cases cited by these authors. Cf. Matter of Frécon, D. H. 1935. 183, infra at note 54.

${ }^{30}$ Cf. Hauriou's note under the Piment case, S. 1910.3.129, Jurisprudence (1929) Vol. I, p. 604 at 609.

${ }^{38}$ Duguit, Traité, Vol. 3, p. 709. Cf. also Waline, Manuel, pp. 443-444, as to indications in the Conseil d'Etat of a tendency away from the doctrine of actes inexistants (Ministre des Travaux publics v. Mahieu, D. H. 1932.154, S. 1932.3 .60$)$.

is The distinction between the nonexisting executory decision and the wholly unauthorized act of execution has not always been made. It seems to have been stated clearly only recently by Professor Waline in his note accompanying the Action française case (D. 1 935.3.25 at 26:2). Cf., for instance, Appleton, pp. 103-105, 593 ff.; Hauriou, Précis, r 2th ed., p. 578. See Duguit, Traité, Vol. 3, pp. 71 $0-7$ I 5 ; cf. Dareste, p. 155 , note 3.

${ }^{80}$ Laferrière, Vol. I, p. 530; cf. Duguit, Traité, Vol. 3, p. 709; Hauriou, Précis, I 2th ed., p. 578; Appleton, pp. 104-105;Bonnard, Précis, p. 158; Waline, Manuel, p. 57 ; note in D. 1935.3.25 at $26 \mathrm{ff}$. (see the conclusions of 
The courts themselves do not seem to have ever given a clear definition of administrative trespass. Nevertheless the concept has served in numerous cases as a criterion of jurisdiction. Obviously the reluctance to indicate the probable limits of its application is calculated to preserve the freedom to predicate the ordinary jurisdiction over acts of administrative origin on other grounds than that they are "nonadministrative." This applies equally to the administrative and to the judicial courts, as well as to the Tribunal des conflits, in their respective concessions, assertions and affirmations of that jurisdiction. ${ }^{36}$

In the frequent applications of the doctrine of voie de fait, the jurisdiction of the civil courts has commonly been justified by emphasizing only the "nonadministrative" character of the

the commissaire du gouvernement, ibid.). Cf. also, Dareste, pp. 262-267, 271-279; Teissier, La responsabilité de la puissance publique (1 906), pp. 55-58.

${ }^{* 3}$ In the case of Favre v. Mas, D. 1 904.2.321, referred to by Dareste, p. 274, note 3 , the Cour d'appel de Lyon held that the arrest by three police officers (agents des moeurs), without warrant or express authority of law, of a woman suspected of prostitution because of her alleged conduct constituted a judicial and not an administrative act, even though performed by administrative officers. Consequently the judicial authority was competent in the matter of damages which the woman sought to recover for the illegal arrest; for the judicial courts are "the natural guardians of individual liberty" and, in principle, their jurisdiction extends to all questions affecting that right. Dareste (ibid.) points out that this formula was used to circumvent the necessity of having the legality of an administrative act determined by the administrative jurisdiction (see question préjudicielle, chap. VI, note 5I, supra). However, instead of reaching the same result by way of the simple and unquestionably applicable doctrine of trespass (Duguit, Traité, Vol. 3, p. 30), the court rested its authority upon the judicial nature of the act. (But see the law of Feb. 7, 1933, supra, note 10 , vesting jurisdiction in all matters of individual liberty in the ordinary courts and excluding conflicts where acts performed by administrative agents are involved.)

In several cases of seizures (infra, chap. $X$, note 9 ) performed by police agents, the Conseil d'État refused to take jurisdiction, and the Tribunal des conflits under similar circumstances confirmed the ordinary jurisdiction on the ground that the acts of seizure were judicial in nature. The acts in those cases were indeed authorized under statutes appointing the particular administrative agents officers of the police judiciare. (See Berthélemy, Traité élémentaire de droit administratif, 1 $3_{\text {th }}$ ed. (1933), p. 267.) Nevertheless it would seem to have presented little difficulty to term administrative an act as plainly so as the seizure of property. By way of analogy, if acts performed by administrative officers are not necessarily administrative, acts emanating from judicial officers need not indiscriminately be deemed judicial. 
act complained of. ${ }^{37}$ Thus, superficially, the primary concern seems to have been that the principle of differentiated agencies should be left unimpaired. Nevertheless, sight must not be lost of the fact that every trespass presupposes the violation of a personal right. Hence the question becomes at once pertinent whether the rule of judicial competence in cases of administrative trespass is not in fact a manifestation of the desire to remit the protection of all civil liberties and property rights to the ordinary courts.

\section{(a) Applications}

i. Illegal arrest. The Cour de cassation, in 1876 , in the case of Labadié v. Gaillardon, ${ }^{38}$ decided that an illegal arrest followed by unlawfully prolonged detention was not an administrative act and that therefore the lower civil court was competent to take cognizance. Although there is no express reference, the decision is a manifest application of the trespass doctrine, revealed in this language: "In passing upon the character [illegality] and the consequences [invasion of personal liberty] of the act, the court below did not interfere with any administrative act, and consequently did not violate the principle of the differentiation of agencies."39

\footnotetext{
${ }^{87}$ Hauriou, Précis, Ioth ed., p. 35, I 2th ed., p. 27 ; Bonnard, Précis, p. 157 ;
} Waline, Manuel, p. 56.

${ }^{36}$ D. 1876.1 .289 at 296 . Gaillardon was arrested upon the order of Labadie shortly before the latter received a telegram containing his expected nomination as prefect. Thereafter the prefect permitted Gaillardon to be detained seven days without a hearing. Gaillardon committed suicide, and his widow sued the prefect personally in the civil courts for indemnity and recovered the judgment which the defendant below asked the Cour de cassation to set aside.

The case is noteworthy also because it is in sharp contrast with the later case of Favre v. Mas, D. 1904.2.321, supra, note 36, in that it expressly holds that the act of arrest was not a judicial function subject to inquiry only in the ordinary courts. The point is discussed with elaboration in the note accompanying the report of the decision.

Cf. Matter of Ginière, Rec. I 904.88, where the Conseil d'Etat, without qualifying its grounds for the rejet, declined to take jurisdiction over a case of alleged arbitrary arrest of a woman. 


\section{I44 REVIEW OF ADMINISTRATIVE ACTS}

ii. Illegal interference with religious. freedom. In Curé de Réalmont v. Maire de Réalmont, ${ }^{40}$ the Tribunal des conflits recently upheld the jurisdiction of a civil court which had been invoked by a church community to secure relief from administrative interference with property devoted to religious purposes. The action taken by the mayor was deemed not to conform to the resolution passed by the town council, and because of the resultant violation of religious freedom the act was characterized as a trespass. ${ }^{41}$

There is a series of interesting decisions of the Tribunal des conflits involving invasions of religious freedom in which the trespass doctrine was applied and the judicial competence affirmed. ${ }^{42}$ The question presented by these cases was the authority of a mayor to order the ringing of church bells on the occasion of civil interments. Under certain statutes ${ }^{43}$ and regulations, ${ }^{44}$ church bells are recognized as belonging to the religious cult, except in case of public danger and except as local laws or local custom authorize their use for other purposes. In each case the mayor's order to ring the bells at a civil burial, having been found to be contrary to existing laws and regulations and without the sanction of a local custom, was held not an administrative act, but a voie de fait and subject to redress in the civil courts. ${ }^{45}$

${ }^{40}$ S. $1935 \cdot 3.97$.

12 The council had authorized the construction of a public comfort station at a designated location behind a church building. The mayor had part of an iron fence upon the church property removed and had the station placed up against the church. In order to occupy premises devoted to religious cults it would have been necessary to follow a specific statutory procedure.

${ }^{2}$ Abbé Piment v. Guichard-Voillemond, Maire, Rec. 1910.323 , S. 1 9 10.3.1 29, D. 1911.3.41; Abbé Mignon v. Godet, Rec. 1910.442, D. 1911.3.41; Abbé Thiney v. Dompnier, Rec. 1916.52. See also Duguit, Traité, Vol. 3, p. 716; Jèze, Principes, p. 78 .

${ }^{48}$ Art. 27 , law of Dec. 9, 1905 ; art. 5, law of Jan. 2, 1907.

4t Art. 51, Ordinance of March 16, 1906.

${ }^{45} \mathrm{Cf}$., however, the recourse for excess of power to the Conseil d'Etat in the case of Abbé Bruant v. Maire de Breurey-les-Faverney, D. I911.3.4I, S. 1910.3.129. Lnder identical facts, with the exception that the mayor alleged 
iii. Illegal damage to land. In I892, the conflict arising from the case of Lebel $v$. Bault ${ }^{48}$ was decided in favor of the jurisdiction of the ordinary courts. An action had been instituted to recover possession of land, to enjoin the taking of material from the land, to have the land restored to its previous condition, and to recover damages for material already removed and used for maintenance work on a public road. The Tribunal found that the taking of the material was illegal and a trespass because of nonobservance of statutory formalities. ${ }^{47}$

The Cour de cassation in Ville de Mende v. Roussel ( 1905$)^{48}$ held that the Cour d'appel de Nîmes did not violate the principle of the differentiation of agencies by ordering the city to restore, at its cost, a private water supply which had been destroyed by its agents, without observing the required procedure. The action taken was termed a trespass. ${ }^{49}$

iv. Illegal military requisition. In 1930, the Tribunal des conflits resolved a negative conflict ${ }^{50}$ arising from the refusal of both the civil courts and the Conseil d'Etat to exercise jurisdiction in an action for damages by the Union Villeneuvoise de Conserves, ${ }^{51}$ whose canning plant had been taken

a local custom, the Conseil d'Etat (July 8, 1 910) apparently treated the act as administrative, though it denied the existence of a local custom, and annulled it.

In a note concerning this and the above decisions (in S. 1910.3.129, and Jurisprudence, Vol. I, pp. 604, 609 ff.), Hauriou reconciled the holding of the Conseil d'Etat with those of the Tribunal des conflits, suggesting that the order of the mayor to ring the bells was considered by the Conseil as a décision éxécutoire while the Tribunal treated it as an act of execution. This dual aspect of an order, or the coincidence of a preliminary determination with the order causing its execution, is only possible in case of verbal orders in which the two elements, though present, cannot be readily distinguished.

${ }^{46}$ D. $1892 \cdot 3 \cdot 110$.

${ }^{47}$ Authorization by prefect, according to Law of May 21, 1836, art. 17. See "procedural trespass," infra, p. 151.

29 D. 1910.1 .266 at 269 .

"See "procedural trespass," infra, p. I 51.

'0 Supra, p. 27.

D. H. 1931.135. 
over by the military authorities. The Tribunal ordered the civil court to take cognizance because the requisition, which had not been made in conformity with statutory formalities, constituted a trespass.

v. Illegal encroachments on private property. A typical situation that has found its way into the courts with some frequency is the encroachment on private property in the course of installing electric line equipment. As early as I 884 the Tribunal des conflits in Neveux v. Administration des postes et télégraphes ${ }^{52}$ affirmed the competence of the civil courts in which an action was pending against the post office department on account of the installation of telephone line equipment and apparatus on top of plaintiff's buildings. Finding that the prefect, in ordering the construction upon private property, had acted without statutory or regulatory authority, the Tribunal held that the act was not administrative. ${ }^{53}$ In a recent case, Matter of Frécon, ${ }^{54}$ the Conseil d'État again termed a voie de fait the act of placing telephone line supports into the façades of private buildings without observing the statutory procedure which had been prescribed in I 885 , as the sequel to the Neveux case. ${ }^{55}$

${ }^{52}$ Rec. 1884.909 .

${ }^{\infty}$ In consequence of this litigation, the competent minister submitted a draft of a statute regulating the procedure to be followed by the prefect under similar circumstances. It became law on July 28,1885 .

${ }^{6}$ D. H. I 935.183 . See 52 R. D. P. (1935) 340 and cases cited there. Cf. the five cases in D. 1937.1.17 (Cour de cassation), summarized 54 R. D. $P$. (1937) 517: Compagnie nouvelle d'éclairage, etc. v. Guiringaud; Régie du Syndicat intercommunal, etc. v. Same; Béziat v. Société Nord-Lumière; Syndicat des communes, etc. v. Société Phelan-Ségur; Syndicat des communes, etc. v. Société Cuvelier.

"Supra, note 52. The Conseil d'Etat "annulled" the act of the department and referred the plaintiff to the civil courts "which alone are competent to adjudicate the consequences of a voie de fait." The annulment of an executed decision of course amounts to no more than a censure, and the holding of the Conseil d'Etat does not imply that such an annulment was necessary before the civil court could take jurisdiction. Had the case been brought before the civil court at the outset, and had the administrative asserted a conflict, the latter would unquestionably have been resolved in favor of immediate action 
vi. Illegal abridgment of the freedom of the press. Invasions of the freedom of the press have given further occasion to sustain the power of the ordinary courts to grant relief from the administrative action. In the widely discussed case of L'Action française, ${ }^{56}$ the Tribunal des conflits held "the general seizure of a newspaper, wherever the same may be offered for sale" on a certain day, to be a trespass and subject to redress in the civil courts. The court's decision was based upon the ground that the measure, as taken by the prefect of Paris, was not indispensable to the restoration and maintenance of the public order.

\section{(b) Evaluation}

Laferrière, ${ }^{57}$ when expounding the theory of the judicial protectorate of civil liberties and property, envisaged situations virtually identical with those involved in the foregoing cases. These examples lead with indisputable force to the conclusion that in the case of trespass the jurisdiction of the ordinary courts rests entirely on the fact of invasion of personal rights. Nevertheless this conclusion must be viewed with caution in order not to do violence to basic concepts of the droit administratif. Thus, while violation of civil liberties or of rights of property is an essential element of administrative trespass, the illegality of the invasion is no less important. So far as the courts are concerned, "illegality" refers to the intrinsic or "nonadministrative" nature of the official act, and this illegality, rather than the character of its conse-

in the ordinary courts without the previous intervention of the Conseil d'tat. It may well be supposed that the particular procedure in the case was employed for the very purpose of bringing the matter before the administrative jurisdiction in order to provoke an expression of its attitude towards the issue involved.

${ }^{60}$ L'Action française v. Bonnefoy-Sibour, D. 1935.3.25, noted 53 R. D. P. (1936) 296, discussed infra, chap. X.

or Vol. I, pp. 479-480, 530. 
quences, has been the touchstone of jurisdiction. The emphasis upon the formal aspect of the injurious act is even more evident in the cases of clear trespass in which redress for the violated right is permitted to be had in civil courts on the purely formal ground that the act was nonadministrative because it was judicial. ${ }^{58}$ Moreover, the element of illegality requires especial consideration because, as will be developed further, not all illegal administrative invasions of personal and property rights are trespasses in the sense that they are subject to redress in the ordinary courts.

The utility of the concept of administrative $\operatorname{trespass}^{59}$ and the necessity when applying it of appraising separately the impeached act, as distinguished from its consequences, derive logically from the peculiar situation brought about in France by the interpretation of the separation of powers. It is true that the adjudication of private rights and the dispensation of relief in the event of the violation are generally deemed to be within the exclusive province of the judicial courts. But whenever acts of administrative agencies are involved, the question of their propriety and legality can, according to prevailing doctrine, be passed upon only by the administrative

${ }^{58}$ Favre v. Mas, D. 1904.2.321, supra, note 36.

There are some attempts to deny completely the soundness of the voie de fait doctrine. Laroque, in a note accompanying the report of the Curé de Réalmont v. Maire de Réalmont decision (S. 1 935.3.97, supra, note 40), questions the grounds for the decision on that account. He finds justification for the jurisdiction of the civil court not in the violation of the freedom of religion but in the illegal entry upon the church property. Generally, he recognizes the principle of judicial competence only in the case of invasion of privatelyowned real estate. See also the note by Blaevoet under the decisions reported in D. 1937.1.17 at $18: 2$, supra, note 54. But see his more recent note (D. 1938.1.106) in which this commentator has fully "reconsidered" the validity of the voie de fait doctrine (ibid. at 1 ro.2). [This note has not been available to the author until a time when it was no longer possible to give a fuller account of this interesting exposition of the doctrine of administrative trespass. However, it may suffice to say that Blaevoet declares himself entirely in accord with Professor Waline's analysis (infra, p. 154) of the trespass concept. D. 1938.1.106 at 111 :1.] 
courts and must always be referred to them.$^{60}$ Under the constitutional and statutory protection guaranteeing administrative autonomy, the administrative courts are the sole judges of the formal validity, the administrative legality of such acts. The administrative department therefore will ordinarily not tolerate its own acts to be condemned, except by its own judicial machinery. It is always directly concerned with the act and its administrative purpose, although the judicial courts may deal with its collateral or secondary effects. However, now and then these effects are so drastic as to be wholly out of proportion to the original administrative object. May it not be assumed then that at such a juncture the administrative department is no longer interested in being identified with the act, and therefore does not insist upon submission of the question of legality for its determination? Is it not more convenient, and less injurious to the administrative prestige, to abandon the enfant terrible to be branded a voie de fait and to be disciplined at the hands of a judicial court?

The trespass concept is elastic. The civil courts may readily resort to it under circumstances where it would be rejected by the administrative courts. The degree of illegality required may vary according to the dissimilar views of the respective courts and these views in turn must be harmonized through the office of the Tribunal des conflits. However, it is certain that the doctrine of administrative trespass has a definite place in French administrative law $^{61}$ and operates in the interest of both administrative and judicial justice. In regard to the latter it offers a special advantage by eliminating in many

${ }^{\infty 0}$ See questions préjudicielles, supra, chap. VI, note 5I; Hauriou, Précis, roth ed., p. 877 , note 2 .

ex See the note by Blaevoet, D. I938.1.106 at I I 2:2. It will be made to appear more clearly (infra, p. I 74) that, notwithstanding the similar jurisdictional implications, voie de fait does not in any way coincide with faute personnelle (supra, chap. VIII). 
instances the necessity of referring to the administrative jurisdiction the question of the legality of acts for which redress is sought.

\section{The Elements of Trespass Analyzed}

The very fact that the doctrine of voie de fait has received close attention and analysis only in the comparatively recent legal literature is significant. It points unquestionably to the cause which, during the past two decades, has engendered a great deal of new and penetrating interest in the relation of the administrative and judicial departments. This cause, in France as in this country, is the rapid expansion of administrative activity since the first World War. Indeed, it would have been strange if during this period the notion of administrative trespass had escaped the searching thought of contemporary legal writers. ${ }^{62}$

\section{(a) Illegality-Usurpation and Procedural Irregularity}

The results of the various analyses to which administrative trespass has been subjected are highly interesting and important for the present investigation. According to Hauriou, who was the first to undertake careful examination and definition, the illegality which may taint the act of an administrative authority can assume two distinct forms. Trespasses may arise not only from usurpation of power, ${ }^{63}$ reflected in the ends towards which the act is directed, but also from the unlawfulness of the means employed, i. e., from disregard of procedural requirements. So Hauriou, ${ }^{64}$ looking only to intrinsic defects, has classified trespass as (I) trespass due to

${ }^{2}$ See Hauriou, Précis, r oth ed., p. 35, 12th ed., p. 26; Bonnard, Précis, p. 157; Waline, note in D. 1935.3.25 at 26.

${ }^{68}$ Supra, p. 139 ff.

4auriou, Précis, soth ed., pp. 35-36, note 3 . 
lack of lawful authority ${ }^{65}$ and (2) trespass due to procedural irregularity ${ }^{66}$ Trespass of the first type presupposes an act performed outside the exercise of authority expressly conferred. Hauriou's qualifying phrase "for want of power". envisages both the constitutional power and authority derived from legislative and quasi-legislative acts. ${ }^{67}$ The absence of a power to act in this instance results in an excess of power attended by a total lack of authority. On the other hand, in the case of a "procedural trespass," there is an excess of power in the sense of a total disregard of required formalities. ${ }^{68}$

A second classification of trespass on the basis of intrinsic illegality, suggested by Bonnard, ${ }^{69}$ seems to differ from the foregoing in form but not in substance. Bonnard distinguishes (a) trespass because of irregularity in the executed decision, and (b) trespass because of irregularity in the act of execution. The former is attributed to the virtual nonexistence of the purported decision, ${ }^{70}$ which is ineffectual because it tends

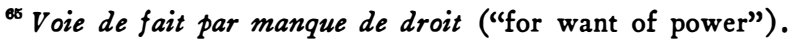

"Voie de fait par manque de procédure ("for want of procedure").

${ }^{07}$ Cf. Abbé Piment v. Guichard-Voillemond, Maire, Rec. r910.323, S. 1910.3.129, D. 1911.3.41, supra, note 42. Hauriou, Précis, 1 oth ed., pp. 34, 52 , emphasizes that there is an autonomous regulatory power which the administrative may exercise to determine its own "rights" within a domain that not even the legislature may arbitrarily limit. If on the one hand the administrative has only such "rights" as have been specifically regulated by legislative enactment or by its own rules, the administrative rule-making power, on the other hand, although it must not run contrary to the laws, may be exercised to the extent that it is not expressly limited by law. See also ibid., p. 35, note $\mathrm{I}$.

Cf. Andersen, Ungültige Verwaltungsakte (1927), pp. 293, $303 \mathrm{ff}$. And see also Jellinek, Gesetz und Verordnung (1 887), pp. 24 ff., 366 ff., 395 ff., Mayer, Deutsches Verwaltungsrecht, 2d ed. (1914), Vol. I, p. $65 \mathrm{ff}$.

${ }^{68}$ See Hauriou's note under Société immobilière de Saint-Just v. Préfet du Rhône, S. I 904.3.1 7 at I $8: 1$, Jurisprudence, Vol. I, p. 84 at 100: "it is very important to confine the administration to its habitual procedure, otherwise, whenever the ordinary methods (mesures de haute police) proved inconvenient, there would be added extraordinary procedures. . . . There should no more be extraordinary methods in administration than in the courts of justice."

'Bonnard, Précis, p. 157.

${ }^{70}$ Supra, p. 140, cf. Jèze, Principes, p. 78. 
to operate upon a subject matter wholly beyond the powers of the administrative ${ }^{71}$ or because it was made without express statutory authority. The latter is said to arise whenever one of the following defects is present: (I) intrinsic illegality in the means of execution, (2) abuse of an intrinsically legal means, (3) employment of a legal means of execution but with complete disregard of the procedure prescribed, (4) employment of a legally permissible method of enforcement but without the judicial authorization which (subject to certain exceptions) ${ }^{\mathbf{7 2}}$ is required in all cases of direct execution against persons or property. It is interesting that in this one instance Bonnard associates the trespass doctrine with the principle that the jurisdiction of the ordinary courts extends to all questions concerning individual liberty and private property. However, there seems to be no adequate reason for differentiating between invasions of the private domain through the direct enforcement of general police measures against persons and property, as in the case of arrests or seizures, and incidental encroachments arising in connection with administrative operations, for instance, the appropriation of private property for the public benefit. Taking Bonnard's analysis as a whole, the situations contemplated under (a) clearly, and those under (b) (I) and (2) if only slightly reformulated, correspond to Hauriou's manque de droit, while (b) (3) and (4) are typical instances of manque de procédure. "Nonobservance of procedural requirements" has not always been distinguished from "lack of authority under positive general rules" as a separate form of intrinsic infirmity which may corrupt the acts of administrative agents. ${ }^{\mathbf{7 3}}$ Never-

${ }^{71}$ Supra, p. 139. See Duguit, Etudes de droit public, ( 1901) Vol. I, p. I I ff.; Esmein, Eléments de droit constitutionnel français et comparé, 7 th ed. (1921), Vol. 1, pp. 33-35, 548.

Infra, p. $164 \mathrm{ff}$.

${ }^{73}$ See, for instance, Duguit, Traité, Vol. 3, pp. 709-10, 716-717; Appleton, op. 104-5, 593-94. 
theless, there are many instances in which the courts have unmistakably recognized procedural trespass. Some examples will be found among the cases which have been previously discussed. Thus, in the Réalmont case ${ }^{74}$ the court held that "in the absence of a disappropriation effected in accordance with the statutory provisions, ${ }^{75}$ the removal of the fence and the installation of the public comfort station . . . constituted a trespass." ${ }^{76}$ Instances of purely procedural trespass occur frequently in connection with the taking of private property for public use. So in the Lebel case ${ }^{77}$ the failure to obtain the authorization of the prefect ${ }^{78}$ required by statute caused the removal of materials from private land for road purposes to be characterized as a trespass. Similar results were reached because of the disregard of statutory procedure in the Union Villeneuvoise ${ }^{79}$ and the Frécon ${ }^{80}$ cases. $^{81}$

${ }^{74}$ Supra, note 40.

${ }^{75}$ Art. I 3 of the law of Dec. 9, r 905 , concerning the separation of church and state provides that church property can be taken only upon securing a decree from the Conseil d'Etat or in pursuance of a special act of the legislature.

${ }^{76} \mathrm{~S}$. 1935.3 .97 at $99: 1$. The court's language in this case indicates that a double trespass was found. Not only had church property been taken without observing certain statutory formalities, but at the same time religious freedom had been violated.

The invasion of liberties through the taking of private property may occur in other situations as well. Compare the seizure of newspapers or printing machinery, which also involve encroachment upon the freedom of the press. Obviously coincidences of this type, together with the comparative frequency of trespass in regard to property, have militated against the recognition by some writers of the utility of the concept of voie de fait administrative.

${ }^{77}$ Supra, note 46.

${ }^{78}$ Art. 17 of the law of May 21, I 836, concerning rural highways.

${ }^{7}$ Supra, note 51. The formalities prescribed by the law of July 3, 1877 (as amended) relative to military requisitions had been completely omitted.

${ }^{80}$ Supra, note 54. Telephone line equipment had been attached to the walls of a privately-owned building with complete disregard of the requirements of notice and hearing provided by art. 6 et seq. of the law of July 28,1885 , regulating the construction, maintenance, and operation of telegraph and telephone lines.

${ }^{8}$ See also Répertoire pratique de législation de doctrine et de jurisprudence ( 19 I 2 ), Vol. 3, pp. 257-58, Nos. I 36 et seq. 
(b) Invasion of Civil Liberties and Property Rights

Until very recently, analytical treatment remained confined to the forms of inherent illegality which convert the act of an administrative agency into a trespass. The attendant violations of specific rights and liberties have received only incidental attention. ${ }^{82}$ However, the aftermath of an uncommonly important decision rendered by the Tribunal des conflits on April 8, I 935 brought forth penetrating examination of the elements of voie de fait by Professor Waline. ${ }^{83}$ For the first time an equal amount of attention was given to the criterion of "invasion of private property or of public liberties." ${ }^{84}$ Waline has demonstrated that actually the violation of a right or of a liberty is sufficient to constitute a trespass only where the injury is especially severe. ${ }^{85}$ The relevancy of the degree or magnitude of the unlawful invasion of rights and liberties is exemplified by cases in which the jurisdiction of the ordinary courts was not conceded although the prerequisites of voie de fait seemed fully satisfied.

${ }^{82}$ Hauriou, Précis, roth ed., p. 35 ; Bonnard, Précis, p. 157.

${ }^{83}$ See Waline's note in D. 1935.3.25. Waline is otherwise in agreement with Hauriou and Bonnard and distinguishes trespass arising from complete want of authority from trespass due to nonobservance of formalities prescribed by statute and especially intended for the protection of private persons.

$\$ 4$ "By public liberties are understood certain rights whose exercise appears particularly precious to the individual, and which, therefore, have been guaranteed by the laws or by the constitution." Waline, Manuel, p. 52.

${ }^{85}$ See note by Blaevoet, D. I 938.1.1 06 at I I I : I. 


\title{
Recent Applications of the Trespass Doctrine
}

\author{
A. THE ACTION FRANCGISE CASE
}

$\longrightarrow$

TOR complete understanding of the significance of the doctrine of administrative trespass in French law, it is necessary to examine in detail the resolution of the conflict in the case of $L^{\prime}$ Action française v. Bonnefoy-Sibour. ${ }^{1}$

The Action française case involved the powers of administrative agencies in regard to the freedom of the press, and the conclusion reached is in striking contrast to the earlier

${ }^{1}$ D. I 935.3 .25 , noted 53 R. D. P. (1936) 296. The decision is in the customarily concise form: "The laws of August 16-24, 1790, Fructidor 16, year III, Pluviose 28, year VIII, July 29, I 88 I and April 5, I884, have been examined.

"Considering that the action instituted by the publishing company L'Action française against Bonnefoy-Sibour before the justice of the peace of the northern canton of Versailles has for its object the reparation of the damage caused by the seizure of the newspaper L'Action française on the morning of February 7, 1934, ordered by the prefect of police to be made at the depositories of that newspaper in Paris and in the Department of the Seine; considering that the seizure of newspapers is regulated by the law of July 29, I88I; that, although it is the duty of mayors, and in Paris of the prefect of police, to take all measures necessary for the preservation of public order and safety, these duties do not carry with them the power to cause, as a preventive measure, the seizure of a newspaper without a showing that the seizure, ordered in such a general manner as appears from the record, viz., wherever the newspaper shall be offered for sale, in Paris as well as in the suburbs, was indispensable for the maintenance or restoration of public order; that, therefore, the measure attacked in the circumstances constituted merely a trespass so that the ordinary courts have jurisdiction over the case now pending before the court of Versailles; considering, nevertheless, that the court could not, without exceeding its powers, condemn the prefect to the costs on account of the rejection of his challenge [concerning the jurisdiction], because the prefect [in asserting a conflict] did not act as a party to the proceeding but as representative of the sovereign power:

"Art. I. The arrêté de conflit made by the Prefect of Seine-and-Oise on December 20, 1934 is annulled.

"Art. 2. The disposition in the judgment of the civil court of Versailles, dated December 14, 1934, condemning the Prefect of Seine-and-Oise to the costs is deemed not to have been made." 
holdings in the Pelletier ${ }^{2}$ and Gounouilhou ${ }^{3}$ cases. Upon the order of the prefect of police of Paris, the newspaper L'Action française had been seized on the morning of February 7, 1934, at all places where it was held for sale and distribution within the city of Paris and the Department of the Seine. The plaintiff publisher instituted an action for damages in the civil court of Versailles, whose jurisdiction was affirmed by the Tribunal des conflits after it had been challenged by the defendant prefect. The seizure had been ordered during the grave political situation existing in Paris on the night of February 6, and the commissaire du gouvernement pointed out that "if ever a police prefect could make use of exceptional powers it was during that night, and the seizure of newspapers containing appeals to riot could well constitute a legitimate use of the police power to the extent that the seizure was indispensable to the prevention of renewed and more serious disorders." 5 The conclusions of Commissaire Josse, which the Tribunal adopted, rest on a minute analysis of the jurisdictional issue involved, and thus considerable light is thrown upon the broader implications of the trespass doctrine and upon the import of its application in the case.

The Tribunal des conflits had to determine whether or not it was proper for the civil court of Versailles to allow the action against the prefect. This rendered it necessary to consider individually the possible factors which could subject the act of an administrative agency to the scrutiny of a civil court.

\footnotetext{
${ }^{2}$ Supra, chap. VII, note 60.

Supra, chap. VIII, note 29 ; note particularly Laferrière's interesting criticism, ibid. at note 31 .

D. 1935.3 .25 at $30: 2$.

'The prefect of police, under article 8 of a regulation of March 13, 1924, concerning newsstand concessions by the city of Paris, had power to prohibit the sale at stands of newspapers which in his opinion endangered the public order; but he had no such special power as to the sale in other places, as for instance in the streets.
} 
In the first place the question arose whether the prefect had committed a faute personnelle $e^{b}$ which would involve his personal liability. This question was answered in the negative by the commissaire, ${ }^{7}$ and implicitly by the court, on the ground that obviously the prefect had acted not from personal motives but from the manifest desire to restore and maintain public order in the city of Paris on that critical date. In other words, he "exercised police powers which he had, or believed he had; whether wrongly or rightly, legally or illegally, matters little as far as jurisdiction is concerned."

The second consideration was the apparent analogy in the facts of the case to those of three earlier cases ${ }^{9}$ decided by the Tribunal des conflits in I 889. At that time the Tribunal had held the ordinary courts competent to entertain suits instituted against three prefects as the sequel to certain seizures which were found to constitute invasions of the freedom of the press. It had to be determined, therefore, whether the principle upon which jurisdiction depended in the former cases was applicable to the present case. The commissaire

${ }^{B}$ Supra, chap. VIII.

${ }^{7}$ Commissaire Josse, relying on Laferrière's definition of faute personnelle as an act "which reveals the man with his human weaknesses, his passions, his indiscretions," and not "the official, the representative of the state, more or less subject to errors." Supra, chap. VIII, note 9 .

${ }^{8}$ D. $1935 \cdot 3.25$ at $28: 1$.

${ }^{\circ}$ Defeuille v. Préfet de police, Usannaz-Joris v. Lefebvre du Grosriez, préfet de la Savoie, and Michau et Lafreney v. Boegner, préfet du Loiret, D. I 890.3.65. All of these cases involved political agitations directed against the republican government by the former nobility of France, in particular by Phillipe, Count of Paris. In the first case the prefect of police of Paris had ordered the seizure of a manifesto addressed by the Count of Paris to mayors and towns of France, as well as of plates and signature stamps used in the printing. In the second case the Prefect of Savoy had seized at a post office letters similarly addressed and containing copies of the same manifesto. In the third case the Prefect of Loiret ordered the seizure of likenesses of the Count of Paris to be distributed with a newspaper. The courts in which the respective complaints were received were held to have power to give relief by ordering the restitution of the confiscated property or by assessing damages against the prefects; not, however, by holding the postmaster liable in damages for having surrendered the letters, as in the second case. 
demonstrated at length that the earlier decisions could no longer stand as precedents, notwithstanding the fact that the freedom of the press was still regulated by the law of July 29, I $88 \mathrm{I},{ }^{10}$ prohibiting preventive confiscations by the administrative and permitting seizures only in aid of criminal prosecutions for specifically designated offenses. ${ }^{11}$ This law had not been made the basis of the former adjudications, but the jurisdiction of the civil courts in those cases had been upheld on the ground that the respective prefects had acted as "officers of the judicial police"12 under powers conferred by article Io of the Code d'instruction criminelle. Since in the Action française case the prefect had not acted in such capacity nor in aid of a criminal prosecution, ${ }^{13}$ but strictly in the exercise of police powers, justification for the ordinary jurisdiction had to be found elsewhere.

The seizure of the newspaper L'Action française had the appearance of a bona fide act of an administrative official performed in the exercise of his functions. The opinion of the commissaire points out that under normal circumstances the administrative seizure of newspapers would amount to such a flagrant violation of the freedom of the press that it could not be considered an exercise of police powers, but would

${ }^{10}$ As amended, Dec. 1 2, 1893.

${ }^{11}$ Provocation to such crimes as murder and arson, and to crimes against the security of the state (see law of December 12, 1893 ).

${ }^{12} \mathrm{Cf}$. the instances of illegal arrest (supra, chap. IX, notes 38,39 ), where the jurisdiction also was predicated upon the judicial nature of the function. Cf. also the cases cited by the commissaire (Matters of Spitz, Rec. 1920.1006; Dubois, Rec. 1921.231; Cons. Huignard, Rec. 1923.727; Marquié, Rec. 1926.383 ) in which the Conseil d'Etat declined to assume jurisdiction because the seizures had been made by commissaires de police "acting in their capacity as officers of the judicial police."

${ }^{18}$ At the particular time, art. Io of the Code d'instruction criminelle was not in force, having been abrogated by the law of Feb. 7, 1933 (supra, chap. IX, note 10). It was, however, re-enacted by art. 6 of the law of March 25, 1935, amending the Code d'instruction criminelle. See Waline, Manuel élémentaire de droit administratif (1936) p. 450. 
clearly constitute a trespass. ${ }^{14}$ However, it is also pointed out that the fact that a liberty, such as the freedom of the press, is protected and that violations are subject to redress according to statute does not nullify the police powers which the administrative derives from other laws. ${ }^{15}$ It is of par-

${ }^{14}$ D. 1935.3 .25 at $30: 1$, citing two cases decided by the Cour de cassation involving violations of the press law of July 29, I88I: Lajudie v. Pomarède, and Vaugeois-Héron v. Rieunier, D. I 9 19.1.32.

${ }^{15}$ This point is illustrated by a number of cases in which the Conseil d'Etat indicated the extent of the general police power. It was held that the "freedom of advertising" (art. I 5, law of July 29, I 88I, supra, at note 10) was not violated by a police order prohibiting the use of special vehicles for advertising purposes in the streets of Paris, in the interest of the safety and convenience of traffic. Matter of Hostein \& Cie., D. 1 901.3.53; Matter of Compagnie nouvelle des Chalets, etc., Rec. 1902.42. Cf. Matter of Cotte, Rec. 1924.839, concerning the destruction of "suspicious" billboards under the order of a prefect duly authorized by the Minister of the Interior in 1914; held not in violation of the above law of July 29, $188 \mathrm{r}$.

Respecting the scope of the general police power in regard to "public liberties" (peddling, art. 18, law of July 29, 188I), the decision of the Conseil d'État of Nov. 30, 1928, in the matter of Pénicaud (D. H. 1929.39) referred to by the commissaire du gouvernement appears especially pertinent. It was held that the statute did not preclude the exercise by the mayors and prefects of their general police powers in the interest of peace and order, and consequently they could prohibit the distribution of printed matter apt to endanger the public order in the vicinity of schools, churches, barracks, or factories; but that it would be an excess of power and contrary to the statute to prohibit the distribution of all writings whatsoever in all cases where there is a certain congestion of traffic.

Enlarging the background of the extent of the police power, there is repeated emphasis in the conclusions of a decision of the Conseil d'Etat (May 19, 1933) annulling a prefect's decree which prohibited a public address by a named speaker, for the purpose of preventing anticipated disturbances of the public order. The language employed by the court is of interest in connection with the principal case: The right of free assembly being involved "the alleged probability of disturbances was not of such a high degree that the public order could not have been maintained without prohibiting the meeting." This implies that under different circumstances the same order might have been a proper police measure. Matter of Benjamin, D. 1933.3.54 at 57 (italics supplied).

Completing the outline, two cases of confiscation are considered in order to demonstrate the right of the administrative under its general police powers to interfere directly with property rights. In Monpillié v. Maire de Bordeaux, D. 1921.1.4I, S. 1918-1919.2.1, supra, chap. VIII, note 71, the Cour de cassation affirmed the incompetence of the ordinary courts in an action against the mayor on account of the seizure of meat brought into the city without having been submitted for inspection and stamping in accordance with a city ordinance. The reason was that both in issuing the order and in causing the seizure pursuant to it, the mayor had remained within his police powers and his administrative functions (art. 97, law of April 5, 1884, Municipal Organization). 
ticular interest to note that the opinion expressly denies that the jurisdiction of the administrative courts is automatically excluded whenever the exercise of such police powers conflicts with a protected liberty. ${ }^{16}$

In drawing the final conclusions essential to the disposition of the principal case, the commissioner relied on the precedents reviewed. He deduced from the earlier decisions that administrative agencies, in the lawful use of their general po-

- lice powers, may indeed curtail constitutional liberties without committing a trespass, and that redress by the ordinary

And the Conseil d'Etat, in principle, decided that a mayor may within his police powers proceed to confiscate deteriorated foods where such action is urgent in view of the existence of serious danger to the public health. Matter of Société Laitière Maggi, D. H. r 924.170.

${ }^{16}$ Additional precedents sanctioning the administrative jurisdiction, i. e., denying the trespass character of the act, in case of illegal invasions of property rights, are cited in Professor Waline's note, D. 1935.3.25. The Conseil d'Etat held itself competent to adjudicate a matter of illegal detention and utilization of a foreign neutral vessel in Matter of Chan Pek Chun, Rec. 1931 .r 12 5. [The case is relied on by Laroque, supra, chap. IX, note 59 , in his endeavor to discredit the voie de fait doctrine.]

In this particular instance the question seems pertinent whether the diplomatic aspects of the case did not contribute to the retention of jurisdiction by the Conseil d'Etat. Furthermore, one may well ask if and upon what grounds the administrative jurisdiction might have been vindicated before the Tribunal des conflits had the action of the owner of the ship been instituted in the civil court.

In the case of Bailly v. Carques, D. 1918.3.1, irregularities in effecting military requisitions of beef cattle and grain, in the opinion of the Tribunal des conflits, did not deprive the respective acts of their administrative character so as to justify the jurisdiction of the civil court. This case should be compared with the Union Villeneuvoise case (supra, chap. IX, note 5I); there is a difference both in the degree of procedural irregularity and in the consequences. The former case involves the taking of personal property, while the latter was concerned with taking possession of an entire factory. It should be noted, however, that in the Bailly case the court did not refer to the trespass doctrine as an alternative solution but rather reached its decision on the basis of the distinction between faute de service and faute personnelle, i. e., by denying the quasi-delictual character of the acts in question. In the third case cited (De Gasté v. Hospices, etc., D. 1895.3.45) the Tribunal des conflits decided in favor of the administrative jurisdiction "because there was no trespass, even though construction on a public works had been begun prior to any administrative formalities and a water course to which plaintiffs claimed a right had been diverted." Waline, D. 1935.3.25. It should nevertheless also be noted that the court expressly held that there had been no dispossession and that the right claimed was not a property right. 
courts is not available unless the act complained of involves a malfeasance or usurpation of power. Consequently the seizure in the Action française case could be impeached in a civil court only if there was something in the attending circumstances which deprived the act of the prefect of its apparently administrative character, thus reducing it to an unqualified violation of the law protecting the freedom of the press. ${ }^{17}$ The test of this proposition depended upon the answers to two separate questions: (I) Did the police powers of the prefect under the particular circumstances extend to the seizure of the newspaper? (2) If so, was the seizure ordered and made as a means to an end, or as an end in itself?

The first question presents two aspects, being concerned both with the existence of the powers as such, and with the mode of exercising them. The general scope of the powers of the prefect of police in regard to the press could be readily determined. Thus, according to the express terms of the concessions of the city-owned newsstands, the display and sale of publications which were held to endanger the public order could be prohibited. Furthermore, since the police authorities were charged with the maintenance of order in the public streets, ${ }^{18}$ the sale of a newspaper inciting to violence in the streets of an already inflamed city could also be prohibited by the prefect. However, whether the newspaper could be seized raised a different, more delicate issue. The commissaire du gouvernement concluded $^{19}$ that, even though the

${ }^{17}$ Although the 1889 cases (supra, note 9) denied all right of preventive seizure of newspapers, the commissioner insisted that "not every seizure of a newspaper is, nor can be, a trespass" per se.

${ }^{18}$ Baldy v. Préfet de Saône-et-Loire, D. 1920.3.25; see art. 99, law of April 5, 1884, Organization of Municipalities. Cf. Matter of Hostein \& Cie., D. 1901.3.53, supra, note I 5 ; Matter of Compagnie Nouvelle des Chalets, etc., Rec. 1902.42, supra, note 15 .

${ }^{10}$ Reliance was had on the authority of the decision of the Conseil d'Etat in the matter of Anduran, D. 1925.3.43. Upon the recourse of the owner of a flour mill whose plant had been "sealed" because of numerous known and suspected violations of certain statutes, it was held that the administrative de- 
seizure constituted an administrative execution, it was justifiable because of the exceptional circumstances. It was pointed out that under the special terms of the concessions the action taken was appropriate as far as the newsstands were concerned. However, in regard to the street sales it was necessary to construe the seizure as a direct sanction of an implied prohibition to sell. On this basis the seizure could be justified on the ground of the existing emergency and imminent danger.

\section{B. ADMINISTRATIVE EXECUTION AGAINST PERSONS AND}

\section{PROPERTY}

At this point, a more intimate examination of direct administrative execution ${ }^{20}$ in French law is imperative. Professor Waline ${ }^{21}$ has said that that "is one of the most delicate problems of our public law, because it brings into conflict two fundamental principles, personal liberty and the respect due the laws."

Trespasses by administrative agencies often stage their appearance in the cloak of acts of enforcement directed immediately against persons or property. It is important, therefore, to determine under what circumstances direct sanctions may be applied, and when, on the other hand, their use is illegal in the sense that affected parties are entitled to the protection

partment exceeded its powers in resorting to a sanction not specifically provided for in the respective statutes, which afforded other adequate means of enforcement, since this was "not a cause of emergency and immediate danger." (See infra, p. 168.) Commissaire Josse developed the problem of administrative execution more fully in the Anduran case.

${ }^{20}$ Berthélemy, "De l'exercice de la souveraineté par l'autorité administrative," 21 . D. P. (1904) 209; Dareste, Les voies de recours contre les actes de la puissance publique (1914), pp. 71-89; Hauriou, Précis de droit administratif, roth ed. (1921), pp. 77-80, I th ed. (1933), pp. 578-582, and his note accompanying the Saint-Just decision in S. 1904.3.1 7 and La jurisprudence administrative de ${ }_{1892}$ à 1929 (1 929), Vol. I, p. 84 at 99 ff.; Bonnard, Précis de droit administratif (1935), pp. 186-187.

${ }^{21}$ Waline, Manuel élémentaire de droit administratif (1 936), pp. 451-54. 
of the ordinary courts. That one available form of relief, in case of the unauthorized application of such sanctions, is of the injunctive type should be especially noted. For this exceptional, although very limited, power of the French civil courts to enjoin administrative action must be related to the fact that no corresponding remedy is available in the administrative courts. ${ }^{22}$ Attempts have not been lacking to equip the latter with powers of injunction (référés). The difficulty, however, has been that the administrative courts actually have no power to interfere with the execution of administrative orders lawfully made. Thus it is possible to obtain an injunction only by holding the act of enforcement "nonadministrative" and therefore subject to the ordinary jurisdiction.

\section{The Rule of the Saint-Just Case}

The outstanding occasion for dealing exhaustively with the problem of direct sanctions arose in connection with the enforcement of the law regulating religious associations. This statute prohibited the formation of religious congregations without special legislative authorization, and permitted their establishments to be operated only by virtue of a special decree of the Conseil d'État. ${ }^{23}$ In the case of Société immobilière de Saint-Just v. Préfet du Rhône, ${ }^{24}$ the owner of certain premises housing an unauthorized school of the Sisters of St. Charles brought action in the civil court against the prefect, who had ordered the premises sealed after evicting the congregation. The prefect had acted in pursuance of a

${ }^{22}$ Bonnard, Précis, p. 159; Jacquelin. "L'évolution de la procédure administrative," 19 R.D.P. (1903) 373 and $20 R . D$. P. (1903) 5 at 17-19; Hauriou, Jurisprudence, Vol. i, p. 108.

${ }^{2 *}$ Law of July 1, r 901 , art. 13.

${ }^{2}$ Decided December 2, 1902, S. 1 904.3.1 7 ; D. 1903.3.41 ; Hauriou, Jurisprudence, Vol. 1, p. 84 . 
decree of the "ministers in council,"25 and he challenged the competence of the court by asserting a conflict.

The Tribunal des conflits had to decide, for the purpose of determining jurisdiction, whether the action taken by the prefect was within his administrative functions or whether it constituted a trespass. The decision required consideration of the important question of administrative sanctions in the form of direct execution against persons or property. The general rule is that direct enforcement of the commands or prohibitions contained in laws and regulations is permissible only if it has been previously authorized by a judicial court. ${ }^{26}$ Penal sanctions for infractions cannot be applied except upon conviction in the ordinary courts. These courts alone are deemed competent to authorize or to order the appropriate means of execution to be employed. If the administrative department resorts independently to methods of direct enforcement, it is held to violate the principle of differentiation of agencies, ${ }^{27}$ and its action constitutes a trespass because of the illegal invasion of private rights or property.

This general rule is subject to exceptions. Thus, power to apply penal sanctions in a few isolated instances has been conferred upon the administrative courts by statute. ${ }^{28}$ In addition, the rigid application of the principle was found to produce undesirable results, particularly where a law failed to provide sanctions for the violation of its terms. This was the

${ }^{20}$ This being the form of decree required by art. 13 of the law of July I, I 901 , for the closing of such establishments.

${ }^{20}$ See the conclusions of the commissaire du gouvernement in the case; Hauriou, Jurisprudence, Vol. I, p. 86; Dareste, p. 71 ff.; Hauriou, Précis, r oth ed., p. 77, r 2 th ed., p. 580.

${ }^{n}$ See the opinion in the Saint-Just case, S. 1904.3.17 at $22: 2$, quoted by Dareste, p. 83 .

${ }^{20}$ See Laferrière, Traité de la juridiction administrative et des recours contentieux, 2d ed. (1896), Vol. I, pp. 20-21, Vol. 2, p. 629 ff.; cf. Hauriou, Précis, Ioth ed., p. 879 , I 2th ed., p. 350 . The powers originally given have recently been reduced by the law of Dec. 28, 1926. See Berthélemy, Traité élémentaire de droit administratif (1935), p. I146; Waline, Manuel, p. 554. 
condition with which the Tribunal des conflits was confronted in the Saint-Just case. The statute involved in the case, providing penalties and civil sanctions for certain infractions, ${ }^{29}$ did not make provision for the effective enforcement of .a closing order such as was before the Tribunal. Hence it was for the latter to decide whether the statute was to remain a dead letter or whether the responsible administrative agency could supply the sanction which the legislature had omitted. The Tribunal des conflits conceded the authority of the prefect to come to the aid of the statute and to enforce it by sealing the premises. ${ }^{30}$

The cautious conclusions in the case ${ }^{31}$ must be weighed carefully in order to gauge the exact import of the decision, which elicited approving as well as vehemently disapproving comment. It should nevertheless be observed that even the

${ }^{29}$ Law of July 1, 1 901, arts. 8, 1 4, 16.

${ }^{80}$ Commentators have pointed out that it is possible for a law to be entirely devoid of sanctions only because of the restrictive interpretation which the Cour de cassation has placed on art. 471, § 15, of the criminal code (supra, chap. VI, note 7). A more liberal interpretation would make this statute and its penalties applicable in case of violation of any administrative regulation. Consequently laws from which sanctions were omitted could then be effectively supplemented with regulations for the purpose of curing the defect. See the opinion in the Saint-Just case, S. 1904.3.17 at 21:1; Dareste, pp. 71-77; Hauriou, Précis, roth ed., pp. 77-78, Jurisprudence, Vol. 1, pp. 108-109, 126; Moreau, Le règlement administratif ( 1902 ), p. $325 \mathrm{ff}$.

sa The commissaire du gouvernement admitted the equal validity of a theory which denies that an "incomplete" statute may be administratively supplemented, because the guarantee of liberty and property must be the paramount consideration. On the other hand, the commissaire insisted that in France the postulate of the separation of powers implicitly demands that laws shall not be left unenforced. Nevertheless, he recognized the necessity of well-defined limitations upon direct administrative sanctions, for "One cannot overlook the serious disadvantages which 'forced administrative execution' presents. On one hand . . . direct execution by the administrative, 'by default,' without judgment, without opportunity of defense . . . aside from being contrary to our customs, may in certain cases foster arbitrary action and cover up illegalities. On the other hand, the administrative courts are not equipped to protect effectively private rights which might be violated in a flagrant manner through abuses of acts of direct execution; they do not have local judges for the purpose; they do not dispose of injunctive relief [référé] and the slowness of their intervention can often render their efficacy illusory." S. 1 904.3.17 at $21: 2$. 
champions of the doctrine that laws should never be permitted to remain unenforceable ${ }^{32}$ have been keenly aware of the danger to private rights from abuse of the requisite powers. They have stressed the necessity of strictly limiting those powers of the administrative department. ${ }^{33}$ Hauriou's note ${ }^{34}$ on the decision seems to suggest that certain restrictions ${ }^{35}$ proposed by the commissaire du gouvernement would not fully satisfy the exigencies of the situation. The author insisted at the time that, although there may be occasion for direct execution by administrative agencies, these agencies should always conform to customary administrative methods, and should not resort to extraordinary measures. On the other hand, the doctrine has been vigorously condemned by Berthélemy ${ }^{36}$ on the ground that the paramount principle of public law demands that the administrative "exercise only those powers which have been expressly conferred upon it by statute."37

${ }^{2}$ Hauriou, Précis, roth ed., p. 79, I 2th ed., p. 579, Jurisprudence, Vol. I, p. 99; Waline, Manuel, p. 452.

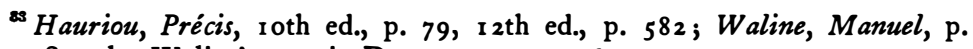
451 . See also Waline's note in D. 1935.3.25 at 26 .

${ }^{34}$ S. 1904.3.17; Jurisprudence, Vol. 1, p. 100 (quotation, supra, chap. IX, note 68). However, the point seems to have been abandoned later on. Cf. Hauriou, Précis, roth ed., pp. 79-80, I 2th ed., pp. 581-582.

${ }^{35}$ See note 38 , infra.

\$ "De l'exercice de la souveraineté par l'autorité administrative," 2 I R. D. P. (1904) $209 \mathrm{ff}$.

${ }^{87}$ Ibid., p. 216. The same writer also states: "The administrative cannot touch our property, put its hand upon our persons, except in pursuance of express statutory authority. Wherever the statute is silent the function of the administrator terminates. . . . the legislative intent may not be presumed if it has not been expressed." Ibid.

It is worth noting that in the country which has sponsored administrative autonomy some of the foremost authorities are constantly pointing out and militating against the danger of opening the door to arbitrariness. Berthélemy sees "behind the independent exercise of sovereign power the spectre of administrative tyranny. . . . the administrative may act only to insure the execution of the laws, only in the forms specified by statute, only to the extent indicated by the statute." Ibid., p. 214. And again, further on, "While one cannot overlook the disadvantages arising from leaving a statute temporarily devoid of all sanction, this disadvantage is not commensurate with the danger 
In the Saint-Just case, the commissaire du gouvernement argued and the court found that in sealing the premises the prefect had acted within his powers. It was further held that the enforcement of the statute in question was accompanied by all the circumstances ${ }^{38}$ necessary to justify direct administrative execution. Thus, the act of the prefect was strictly administrative and, since there had been no trespass, the court had violated the differentiation of agencies by declaring itself competent in the matter. ${ }^{39}$

presented by the introduction into practice of arbitrary administrative procedures not sanctioned by law." Ibid., p. 223. The author concludes that "the actor to whom the program assigns no part must not appear upon the stage." P. 227 . See also the same writer's Traité, p. $349 \mathrm{ff}$.

Cf. Duguit, Traité de droit constitutionnel, 2d ed. (1923), Vol. 3, pp. 7 1 1713 ; cf. also Dareste, p. 86; and the unsigned note in D. 1903.3.4 I.

38 “ 1 . The administrative object for which execution is necessary must have its sources in the express language of a statute;

"2. There must be cause for forced execution because of resistance to a law or to a sovereign command [acte de puissance publique];

"3. The necessity for direct administrative execution must spring from the absence of a penal sanction;

"4. The means of forced execution must tend solely to realize the immediate administrative object envisaged by the statute." Opinion in the case, S. 1904.3 .17 at $21: 3$.

Hauriou (see supra, chap. IX, note 68) at that time insisted that the fourth limitation be further qualified, and he interpreted the decision as satisfying the double requirement. Through an interesting review of the earlier instances of sealing localities as a method of administrative execution, he shows that this has been a means "habitually" employed. Consequently, in the present case it was not an "extraordinary" means which would deprive the act of the prefect of its administrative quality and would remove it from the administrative jurisdiction. (The instances referred to are the suppression of the prerevolutionary system of courts, and the administration of the estates of emigrants and the royal family and of religious associations under the legislation of the years 1 789-1 792.) See Hauriou, Jurisprudence, Vol. 1, p. 1 00 ff.

The commissaire du gouvernement, whose reasoning was adopted by the court, viewed the question of jurisdiction from still another angle. Application to the civil court for an injunction had been made, not by the evicted congregation, but by the owners-lessors of the building. These parties, although they did not do so, might have insisted upon the civil jurisdiction for the protection of their property rights. To meet this implied objection to the exclusive competence of the administrative court in the case, the court pointed out that "to seal the premises and to keep them temporarily sealed" did not amount to "an act of dispossession" such as would automatically confer jurisdiction upon the civil courts. S. 1904.3.17 at $24: 3$.

The civil jurisdiction in the case of expropriation (supra, p. 135) has by analogy been extended to dispossessions by the administrative. See the conclusions of 
The Saint-Just decision became a milestone by establishing the rule that direct administrative sanctions may be employed in order to give effect to a statute which is unenforceable because of a deficiency in its terms. But the decision, through the underlying opinion of the commissaire du gouvernement, also indicates the further and probably far more frequent necessity for such sanctions in case of "extreme emergency in the sense of immediate danger to the general security, public health, or public order." ${ }^{40}$ The picturesque phrase coined by Commissaire Romieu in the case has often been quoted: "When the house is on fire one does not apply to a court for an order directing the firemen to extinguish it."

The Conseil d'État, since its decision in the recourse Suremain, ${ }^{41}$ has adhered to the principle stated in the Saint-Just case in several decisions of more recent date. ${ }^{42}$ These cases hold that administrative agencies may take measures directly affecting persons or property whenever public interests are seriously and immediately endangered, and whenever, under

the commissaire, S. 1 904.3.23:3; Hauriou, Jurisprudence, Vol. 1, pp. 95, 107, Précis, 12 th ed., p. 347. It seems extremely difficult in this particular instance to maintain a clear distinction between a dispossession and a trespass upon private property. In the present case, assuming there had been a dispossession, the civil court obviously would have been held competent although the act remained administrative. But the dispossession of the private owner of real property by an administrative act may very well present all the characteristics of a trespass. The outward guise of a dispossession incidental to an otherwise legal act may conceal a virtual expropriation without the requisite formalities. The complete disregard of procedure combined with the fact of dispossession unquestionably would result in a voie de fait. See Laferrière, Vol. 1, p. 542 ff.; Hauriou, Précis, 12th ed., p. 869 ff.; Bonnard, p. 459 ff.; Waline, Manuel, p. $468 \mathrm{ff}$., 529 ; Berthélemy, Traité, p. $698 \mathrm{ff}$.

${ }^{40}$ S. 1904.3.1 7 at 2 I :1. Hauriou, Précis, roth ed., p. 79, 1 2th ed., p. 581 , takes the position that the absence of a statutory sanction must coincide with emergency. Cf. Bonnard, Précis, p. 158; Waline, Manuel, pp. 450, 453. See also Dareste, pp. 84, 86; Appleton, note under Monpillié v. Gruet, D. 1921. 1.41-42. Cf. Matter of Gilibert, Rec. I 933.930-31.

"11 Decided in 1907, Rec. 1907.345 ff. (see the conclusions of commissaire Romieu, ibid., p. 347).

- In 1913 (Matter of Société française d'industrie chimique, S. 1916.3.1, Hauriou, Jurisprudence, Vol. I, p. 120) a manufacturer of chemical products complained of the action of a prefect who had served notice to discontinue the unauthorized and dangerous manufacture of certain products, and to suspend the previously authorized production of other chemicals on account of changed con- 
these circumstances, the terms of a statute cannot be adequately enforced by applying the sanctions which it provides. ${ }^{43}$

\section{The Saint-Just Rule and the Action Française Case}

The conflict in the Action française case could be resolved only by determining whether or not the seizure involved was a trespass in the sense of an unjustified application of a direct administrative sanction. According to the opinion of the commissaire du gouvernement, the action taken by the prefect, although it was in the nature of a direct execution, was not illegal per se. The prefect was under a legal duty to maintain order; an emergency existed, and the sale of printed matter inciting to violence would have seriously and immediately endangered the public safety. These circumstances called for prompter action than could have been obtained through the intervention of the judicial department. Never-

ditions and considerations of public health, and who also had sealed machinery used in the manufacture. The Conseil d'Etat held that the notice constituted a definite prohibition; however, it condemned the sealing of machinery. The decision on the second point was interpreted to rest implicitly on the ground that there had been no emergency. (See Hauriou's note, S. I 9 16.3.1, Jurisprudence, Vol. 1, p. I 20.) But it seems more likely that the sealing as a means of execution was inappropriate because adequate statutory sanctions were not lacking as in the Saint-Just case, inasmuch as art. $47 \mathrm{I}, \S \mathrm{I5}$, Code Pénal, was operative. This meets the criticism of Duguit, Traité, Vol. 3, p. 7 I3, who insists that the solution in both cases should have been the same. See also Berthélemy, Traité, pp. $355-356$, note.

In a cause of action which arose during the war of I 914 , the Conseil d'Etat approved the action of a prefect who destroyed all advertising signs and their supports in his district, although a government order prescribed the removal of "suspicious" signs only. The ground of decision was "extreme emergency." Matter of Cotte, Rec. 1 924.839. The Conseil d'État in Matter of Société Laitière Maggi, D. H. 1924.I 70, held that the mayor would have been justified in confiscating in plaintiff's plant foodstuffs unfit for consumption, in direct execution of art. 97 of the law of 1884 (Municipal Code), only if this had been necessary because of the imminence of grave danger. In the Anduran case (D. 1 925.3.43), supra, note 19, it was held that the mills could not legally be sealed for contravention of certain statutes by the owner, because there was no emergency and immediate danger, and there were various statutory sanctions with which the prefect could have effectively enforced the infracted rules.

The majority of writers is in agreement on this question. However, Berthélemy adheres staunchly to the theory that under no circumstances may the administrative proceed by way of direct execution. Traité, p. 356, note. 
theless the commissaire concluded that the seizure was a trespass on account of the object towards which it was ultimately directed. Due to the broad scope of the prefect's order "to seize the newspaper Action française at all places where held for sale in Paris and suburbs," the seizure was not limited to designated places within the area where the sale of that newspaper would actually have become a menace to the public order and safety. The apparent purpose of the order therefore was not merely to forestall the potential effect of such sales, but to prevent the distribution of the newspaper. In the language of the opinion, the seizure under the circumstances appeared not as a means to an end but as an end in itself. On the basis of this construction, the commissaire du gouvernement suggested, ${ }^{44}$ and the Tribunal des conflits held, that the act of seizure constituted a trespass and that the civil court had jurisdiction in the case.

Quite obviously the Action française decision suggests new and important considerations in the analysis of administrative trespass. Although the Tribunal des conflits in principle approved an extension of the police powers in regard to the freedom of the press, and by implication in regard to all civil liberties, it indicated at the same time the value of the trespass doctrine as a means of checking administrative discretion. In this respect the decision vindicates Hauriou, who defended the doctrine of voie de fait as necessary to confine administrative activity within its constitutional domain. ${ }^{\mathbf{4 5}}$

4s "What we ask you [the court] ... is that you confirm the existence of a police power to restrict, or paralyze temporarily, civil liberties which are guaranteed and regulated by law, be it the freedom of the press, or the freedom of assembly, whenever exceptional circumstances justify it. You should not disarm the authority of the police by a decision to the contrary. But if, upon confirming this principle, you find that the circumstances in the present case were not such as to render legal a measure as general as the one taken, it is unimportant from the doctrinal point of view. ..." D. 1935.3.25 at 31 i:

${ }^{45}$ See Précis, 1 2th ed., p. 26. Blaevoet (D. 1938.1.106 at 114:2) says that "the recognition of administrative trespass is a means of protection against, and sometimes even of prevention of, arbitrariness." 
Professor Waline, ${ }^{46}$ in evaluating the decision, did not accept the final conclusions of the commissaire du gouvernement in their entirety. The latter saw in the general nature of the scope ${ }^{47}$ and purpose ${ }^{48}$ of the impeached order the element of illegality which deprives an act of its administrative character. Thus the act could be denounced as a trespass upon the freedom of the press, subject to redress by a civil court. There is nothing in the language of the Tribunal directly suggesting an adoption of this construction, and Professor Waline arrived at a somewhat different interpretation. ${ }^{49}$ According to this commentator, the trespass arose from the fact that the seizure, "ordered in such a general manner," was not necessary for the maintenance of order and security. In other words, under the limitations established by the Saint-Just case, ${ }^{\mathbf{5 0}}$ the circumstances did not justify the direct sanction resorted to by the prefect. This suggests that the decision must be taken to hold ${ }^{51}$ (I) that under the circumstances, though not per se, the act of the prefect was illegal, (2) that the act tended to violate a civil liberty, and (3) that the invasion of the freedom of the press which actually resulted from the seizure of the newspaper was sufficiently serious to constitute a trespass.

\section{A THIRD ELEMENT OF TRESPASS-EXTENT OF INVASION}

The necessity of measuring the extent of illegal encroachments upon civil liberties and property rights for the purpose of determining the presence of a voie de fait had never been

${ }^{\infty}$ Note in D. 1935.3 .25 at 27.

"77 "To seize the newspaper in all places where held for sale in Paris and suburbs." [Italics supplied.]

20 To seize certain property without exclusive regard to the immediate concern of maintaining public order.

D. 1935.3 .25 at 27.

${ }^{80}$ Supra, note 24.

'See Waline's note, D. 1935.3.25. 
emphasized prior to the Action française decision. Furthermore, there is nothing in either the opinion or in the tenor of the decision in the case that points to this requirement. On the surface, the only outstanding fact in the Action française case is that an invasion of the freedom of the press for the first time was treated as a trespass. Nevertheless, it is apparent that the Tribunal des conflits did not stigmatize the act of the prefect as a trespass because of the sole fact of invasion of a liberty, but rather because the invasion assumed the drastic form of a seizure. Viewed in the light of this qualification, the precedents disclose a general tendency of the courts to apply the trespass doctrine only in case of serious violations. ${ }^{52}$ So where property rights are involved, a dispossession $^{53}$ seems to be requisite, and this rather as to real property than as to personalty. ${ }^{54}$ Corresponding to dispossession

${ }^{52}$ Waline, ibid., thinks that the presence of a trespass may also depend upon the severity of the formal illegality of the act, citing as an illustration, Lacombe v. Perrier, D. 1876.3 .51 . In that case the Tribunal des conflits, resolving a negative conflict, found a trespass because the mayor had violated a criminal statute by causing graves and corpses to be disturbed in locating the foundations for a church building.

${ }^{5} \mathrm{Cf}$. the introductory notes preceding the report of the decision of the Tribunal des conflits in Montlaur v. Balmigère, Maire de Tournissan (Rec. I 904.888 at 889 ) : "So long as the administrative stays on its own ground, does not invade private property, but reaches it from without only and does not put its hand upon it, the impairment of the owner's enjoyment, no matter how great, is not for judicial cognizance; on the other hand, the judicial courts have exclusive jurisdiction if there is a trespass, i. e., if there is on the part of the state [personne publique] an encroachment, taking, seizure, or usurpation in respect to private real property whose protection is specially entrusted to those courts."

${ }^{54}$ See the cases discussed above (p. 160 ). Note in particular Monpilliè v. Gruet, supra, chap. VIII, note 7I (emphasized in Waline's note, D. 1935.3.25), where even the Cour de cassation denied the jurisdiction of the ordinary courts in a case involving the removal of noninspected meat from stores over the objection of the owners. There was procedural irregularity which in this country would have provoked at least an allegation of want of due process. However, the act was held to be administrative, very probably on the ground that the disregard for procedure was comparatively slight. But again, it may be, as Waline seems to suggest, that the holding was influenced by the fact that only personal property was involved. Evidently the case of Bailly v. Carques, supra, note i6, concerning a procedurally irregular military requisition of cattle and grain, is susceptible of analogous interpretation, and both cases can on the same ground 
as the standard for determining trespass in regard to property rights, ${ }^{55}$ are unlawful detention where personal liberty is involved, ${ }^{56}$ illegal deprivation of the use of property devoted to a cult where religious freedom is concerned, ${ }^{57}$ and seizure or equivalent interferences ${ }^{58}$ in the case of freedom of the press. ${ }^{59}$

\section{VOIE DE FAIT DISTINGUISHED FROM FAUTE PERSONNELLE}

The Action française case, in addition to contributing greatly to the clarification of the concept of administrative trespass, is authority for the important proposition that a voie de fait is not necessarily accompanied by a faute personnelle on the part of the administrative official. ${ }^{60}$ In other words, the act

be contrasted with the contrary holding in the Union Villeneuvoise case, supra, chap. IX, note 51, where the Tribunal des conflits was concerned with the occupation of an entire factory by the military. Cf. also City of Mende v. Roussel, supra, chap. IX, note 48, where the Cour de cassation found in favor of the jurisdiction of the civil court because of a trespass resulting from the destruction of a private water conduit; and De Gasté v. Hospices, supra, note I 6, where, on the contrary, the Tribunal des conflits declared the administrative courts competent in a somewhat similar situation. There was neither a dispossession nor a trespass upon plaintiff's property; furthermore, no property right in the bed of the watercourse but only a right to the water being at stake, compensation for any permanent damage sustained had to be sought in the Conseil de préfecture because it resulted from the construction of a public works. Law of 28 Pluviose, year VIII (Feb. 17, 1800), art. 4.

However, it should be observed that Waline himself seems to take a different view in his Manuel (1936). There he says (p. 56): "The jurisdiction belongs to the civil courts in all cases of trespass, even though there is no dispossession." It would follow that in the foregoing cases where there was no dispossession, the jurisdiction of the administrative courts must be attributed to the absence of a sufficient degree of illegality. Cf. Matter of Frémy, Rec. 1933.11 59, upholding a Conseil de préfecture which had declined to take jurisdiction in a matter of "irregularly taking possession of private property" in connection with the construction of an electric power line.

${ }^{65}$ Waline, D. 1935.3 .25 .

${ }^{68}$ Cf. Labadié v. Gaillardon, supra, chap. IX, note 38.

${ }^{57}$ Cf. Curé de Réalmont v. Mayor, supra, chap. IX, note 40.

${ }^{68}$ See Waline, D. 1935.3.25 at 28:1.

${ }^{58}$ L'Action française v. Bonnefoy-Sibour, supra, note $\mathbf{I}$.

${ }^{\circ 0}$ Jèze, Les principes généraux du droit administratif, $3 \mathrm{~d}$ ed. (1925), p. 79, note 2, has taken the view that there can be no trespass without a personal 
of an administrative official may be nonadministrative without being personal. Thus, trespass by no means precludes good faith and need not involve the personal liability of the administrative agent. Voie de fait, therefore, has been appropriately described as a notion objective, as distinguished from faute personnelle, which is a notion subjective. ${ }^{61}$ It is eminently the "impersonal" aspect of the trespass concept upon which attention must be focussed in appraising its value for comparative purposes.

\section{E. THE SIGNIFICANCE OF THE TRESPASS DOCTRINE}

As a first impression it might seem that the doctrine of administrative trespass bears but a remote relation to the degree of autonomy which under the French conception of the separation of powers the administrative department has enjoyed in the past. Taken at its face value, the oft-employed phrase "a trespass can never be an administrative act" ${ }^{62}$ apparently means that the concept of voie de fait envisages only acts which are so palpably nonadministrative that the jurisdiction of the ordinary courts follows as a necessary consequence. In other words, it may seem that the trespass doctrine contemplates only usurpations of the most obvious kind and as foreign to proper administrative activity as are fautes personnelles. However, the adjudicated cases at once reveal that administrative trespass is not a simple but a complicated and multi-faceted concept. In its application, degrees of illegality and shades of invasion of constitutional

fault of the public officer. See also Duguit, Traité (1923), Vol. 3, p. 7 I5; Appleton, p. 233. But see Hauriou, Précis, roth ed., p. 36, note, who recognized that "in the case of trespass there is frequently malfeasance on the part of the functionary," engaging his personal liability. See also the note by Blaevoet, D. 1938.1 .106 at $113: 1$.

${ }^{1}$ Waline, D. I 935.3.25 at 27:1 ; Blaevoet, D. I 938.1.1 06 at I I 3 :I.

0 See the opinion in L'Action française v. Bonnefoy-Sibour, D. I 935.3 .25 at $31: 1$. 
rights which are destructive of the administrative quality of an act have been distinguished.

It may have been well enough to hold that an act is nonadministrative where an agency clearly overstepped the borders of the domain constitutionally belonging to the administrative department. However, the courts have stigmatized administrative acts as trespasses even though there was color of authority and a legitimate administrative objective pursued in good faith. Moreover, acts clearly authorized and only procedurally irregular have been condemned in the same sense. It is evident, therefore, that the term "nonadministrative" has been useful only as a convenient formula and has concealed the actual function of the trespass doctrine. Manifestly the trespass doctrine has served as a device to overcome the unwieldiness of the principle of the differentiation of agencies. No sweeping modification of this fundamental precept was desired, but there was an obvious and stringent need for a means by which greater play could be given to concerns more pressing than historical considerations.

In its operation the doctrine of administrative trespass proved sufficiently flexible to fill the need it was called upon to supply. Administrative acts affecting private rights were not indiscriminately exposed to the scrutiny of the civil courts. Machinery was available by which the administrative department might seek to vindicate its action whenever it found it desirable to do so. Whenever redress for an alleged voie de fait was sought in the ordinary courts, the department could insist upon the administrative character of the act and could claim jurisdiction before the Tribunal des conflits. On the other hand, the alleged error could be tacitly conceded. Similarly, where relief was sought in the administrative courts, these courts might either assume jurisdiction or they could, of their own accord, denounce the act as a trespass and refer the complainant to the judicial courts. 


\section{I76 REVIEW OF ADMINISTRATIVE ACTS}

The manifold implications surrounding the trespass doctrine indicate that out of a seemingly simple rule of jurisdiction grew a complex device permitting sporadic modifications of the principle of the differentiation of agencies and facilitating the reconciliation of that principle with the "unwritten" rule of ordinary court protection for the constitutional rights and liberties of the people. 


\section{Chapter XI}

\section{Comparison and Conclusions}

T $\mathrm{N}$ the comparison of the French and American systems of reviewing administrative action, the final conclusions 1 must depend upon the relative significance of the doctrines which circumscribe the review powers of the ordinary courts of France and the doctrine of judicial review in the United States. It is unquestionably important that notwithstanding the differentiation of agencies the ordinary courts of France have full power of interpretation in regard to administrative regulations and a substantial amount of control over their legality. Account must further be taken of the doctrine of the nonexistence of executory administrative orders which have been the outgrowth of usurped authority. Adding finally the full weight of the power of the civil courts to grant affirmative relief from flagrantly illegal administrative acts, the striking similarity of the French and American systems becomes evident. In France, as in this country, administrative acts directly affecting persons or property, in order to escape the scrutiny of the judicial courts, must be both constitutional and legal, and the administrative procedure must have conformed to prescribed forms. Thus the postulates of the rule of law and of due process of law in regard to personal liberty and property have been as common to the conception of justice in France as they are today in the United States. The unqualified inference, suggested by the Special Committee on Administrative Law of the American Bar Association, ${ }^{1}$ that France has never had a policy of supremacy of the law must be rejected. The judicial courts of France have had at their command means of control

${ }^{1} 6_{3} \operatorname{Rep.A.B.A.}(1938){ }_{331}$ at 341. 
over administrative action comparable to judicial review in the United States. This power effectively reached administrative policies and was a strong bulwark against the advances of administrative absolutism. The evolution of the system was characteristic of French democracy, and the droit administratif of democratic France did not provide a pattern suitable for administrative absolutism.

\section{Judicial Review in the United States}

The manifest resemblance which, during the reign of the droit administratif, existed in the relation between the administrative and judicial departments of the two countries can best be illustrated by pointing out the essential features of judicial review of administrative action in the United States. The complexity of the maze of procedural devices by which judicial relief from administrative action can or must be obtained ${ }^{2}$ need only be mentioned incidentally in this connection. On the other hand, specific inquiry must be made as to the right to judicial relief which determines the fundamental nature of judicial review. The content of this right, which exists only in the presence of a legally protected interest ${ }^{3}$ adversely affected by administrative action, is of course no greater than the power of the courts to intervene. The courts, in turn, have indicated the extent of their review powers, i. e., their jurisdiction over acts of administrative agencies in terms of constitutional limitations. ${ }^{4}$ Accordingly

2 See Stason, "Methods of Judicial Relief from Administrative Action," 24 A. B. A.J. (1938) 274; see also "Judicial Control of Administrative Agencies in New York," 33 Col. L. Rev. (1933) ro5; Isaacs, "Judicial Review of Administrative Findings," 30 Yale L. J. (1921) 781; Freund, Administrative Powers over Persons and Property (1928), p. 234 ff.; Dickinson, Administrative Justice and the Supremacy of the Law (1927), p. $39 \mathrm{ff}$.

'See Edward Hines Yellow Pine Trustees v. United States, (r923) 263 U. S. 143 .

' Chicago, Milwaukee \& St. Paul Ry. Co. v. Minnesota, (1890) I 34 U. S. 4 18, discussed by Dickinson, pp. 190-93; Freund, The Police Power (1904), 
they cannot review, ${ }^{5}$ except for the question of constitutionality, acts which are legislative or administrative and not judicial in nature, because in reviewing the policies embodied in such acts they would themselves exercise legislative or administrative functions. ${ }^{6}$

\section{Procedural Due Process}

The prerequisite that an administrative act must be " judicial" " in nature in order to be cognizable by the constitutional courts is twofold in meaning. The very courts which derive from it their jurisdiction to review at other times require administrative agencies to employ judicial methods so as to afford constitutional due process of law. ${ }^{8}$ Thus jurisdiction to review, and consequently the right to judicial relief, enlarges. For this right exists not only where (I) the

pp. 391-393; Ohio Valley Water Co. v. Ben Avon Borough, (1920) 253 U. S. 287; United States v. Los Angeles \& S. L. R. Co., (1927) 273 U. S. 299; Federal Radio Commission v. General Electric Co., (1930) 281 U. S. 464; Public Service Commission of Puerto Rico v. Havemeyer, (1936) 296 U. S. 506; Hodges v. Public Service Commission, (1931) i ro W. Va. 649. See also Murray's Lessee v. Hoboken Land \& Improvement Co., (1 855) I 8 How. (59 U. S.) 272 at 284 .

- Relief from administrative action in many cases calls for review of the injurious and impeached act upon a statutory appeal or direct attack through the common-law methods of certiorari, mandamus, prohibition, habeas corpus, and quo warranto. But the act complained of, if it is wholly void, can be collaterally attacked in an action for damages, application for equity injunction, or by way of defense to prosecution for an alleged violation. See Stason, 24 $A$. B. A. J. $274 \mathrm{ff}$.

- Federal Radio Commission v. General Electric Co., (r 930) 28 I U. S. 464 at 467,469 (see chap. V, note 7, supra). Cf. Hodges v. Public Service Commission, (1931) 110 W. Va. 649 at 655 . The rule does not apply in the state courts, which in many instances have been given administrative review powers by statutes. However, if an appeal lies from the state court to the federal courts, the latter cannot take jurisdiction if the state court has acted legislatively or administratively. See Prentis v. Atlantic Coast Line Co., (1908) 2 II U. S. 210 ; Bacon v. Rutland R. Co., (1914) 232 U. S. 134. See chap. V, supra.

" More commonly the function of the administrative agency in this case is referred to as quasi-judicial, both because it is not truly, not wholly, judicial, and because it cannot be judicial under the separation of powers.

${ }^{8}$ Cf. Chicago, Milwaukee \& St. Paul Ry. Co. v. Minnesota, (1890) I 34 U. S. 4 I8. 
primary object of the administrative act is adjudication, ${ }^{9}$ but equally where (2) the method of pursuing an administrative or legislative ${ }^{10}$ end (a) is judicial or (b) violates the due process requirement by failing to be judicial. ${ }^{11}$ Much depends, therefore, upon the types of administrative activity ${ }^{\mathbf{1 2}}$ which the courts have actually treated as judicial and upon the extent to which they have insisted on procedural due process.

The acts of administrative agencies are essentially adjudicative if they are concerned with the determination of existing legal rights and duties. In this case the administrative tribunal virtually performs the function of a specialized court of justice, e. g., in making awards under workmen's compensation statutes, in condemnation proceedings, in adjudicating claims against the government, in determining rights to pensions, patents, ${ }^{13}$ or to land under government grants, or again in exclusion or deportation cases, particularly where the issue of citizenship is involved. However, the requisite judicial element is also considered to be present in various types of actions of nonjudicial tribunals which are directed toward clearly administrative ends. ${ }^{14}$ This is true,

'E. g., the making of awards by workmen's compensation commissions.

${ }^{10}$ E. g., rate-making.

${ }^{11} \mathrm{Cf}$. the similar English approach-Gordon, "Administrative' Tribunals and the Courts," 49 L. $Q$. Rev. (1933) 94 at ror, note I 5: "In other cases, the point is rather the implied obligation of a tribunal to adjudicate, so that if it acts without adjudicating it is liable in trespass for depriving the party of a hearing." P. 1 8 : "The powers expressly given to a tribunal may be clearly legislative, but their exercise conditional on a state of facts, ascertainment of whose existence as clearly requires judicial powers. Then doubt may arise whether the tribunal has by implication the judicial power to adjudicate on this question, or whether the validity of its orders depends on the finding of a Court of law that the conditions were first fulfilled." See also Part II of the same article, 49 L. Q. Rev. 419 at $428 \mathrm{ff}$.

${ }^{12}$ I. e., activities entrusted to, and carried on by, administrative agencies.

${ }^{20}$ It is interesting in this connection to follow the opinion in In re Barratt's Appeal, (1899) I 4 App. D. C. 255 at 257; but cf. Federal Radio Commission v. General Electric Co., (1930) 28 I U. S. 464 at 467.

${ }^{10} \mathrm{Cf}$. chap. V, supra. 
for instance, in regard to the revocation of licenses, abatement of nuisances, removal of officers, and in the classic case of public utility rate-making. The courts have never indicated the exact meaning of the term "judicial" as applied to administrative action; indeed, an attempt to do so is scarcely to be expected in view of the complex tasks with which administrative agencies have been and may hereafter be charged.

The extent of the right to, and the inherent purpose of, judicial review as conceived by the courts is further reflected in its scope. This scope varies according to the respective weight of the public and private interests which must be balanced. Unless designed for the purpose of pure adjudication, administrative action unavoidably brings these interests into conflict, and the reviewing power of the courts-the probable extent of their intervention-may be measured by the intensity of the conflict. ${ }^{15}$ Provided administrative action, socalled, is of the adjudicative type and therefore predominantly judicial both as to object and form in that it is concerned solely with the determination of correlated private rights and duties, ${ }^{16}$ the power to review attaches without hindrance. ${ }^{17}$ On the other hand, where giving effect to a general legislative-administrative policy directly affects rights of persons or property, it is only the process, ${ }^{18}$ as distin-

${ }^{25}$ As to the concurrent operation of the doctrines of administrative finality and of prior resort to administrative agencies, or exhaustion of administrative remedies in the interest of administrative expertness, see chap. V. See also United States Navigation Co. v. Cunard Steamship Co., (1 932 ) 284 U. S. 474; cf. Prentis v. Atlantic Coast Line Co., (1908) 21 I U. S. 210; Palermo Land \& Water Co. v. Railroad Commission, (D. C. Cal. 1915) 227 Fed. 708. And see the dissenting opinion in Crowell v. Benson, (1932) 285 U. S. 22 at 65.

${ }^{16}$ As, for instance, in the case of awards in industrial accident cases and adjudication of claims against the government. In the second instance it is immaterial that one of the parties is the government, since the questions before the tribunal are of a purely private nature arising from contractual or quasicontractual relations.

${ }^{17}$ Cf. Borgnis v. Falk Co., (1911) 147 Wis. 327 .

18 The common use of the term "function" in this and similar connections is believed to be inaccurate and misleading. 
guished from the object, which can be termed judicial. Consequently in such instances judicial review is confined to the administrative mode of procedure. However, here the due process requirement has proved capable of being stressed to such an extent that review by the courts effectively reaches the administrative objective whenever it is deemed desirable to afford protection to large proprietary interests which may be at stake. ${ }^{19}$

\section{The Supremacy of Law}

The right to judicial review thus far appears primarily in the light of a guarantee of procedural due process. Broad as it may be because of the freedom of the courts to define due process in relation to specific needs, the right to court revision of administrative action is by no means limited to the scrutiny of procedural errors. Indeed, the area as well as the efficacy of judicial relief is greatly increased through the power to test the jurisdiction of administrative agencies whose acts are the subject of complaint. This power implementing the postulate of the supremacy of the law is a comprehensive one. If administrative action exceeds constitu-

${ }^{10}$ The cases involving public utility rates are outstanding illustrations, particularly because the issue of confiscation, when raised, must be finally determined by the courts in order to afford due process. See the famous case of Ohio Valley Water Co. v. Ben Avon Borough, (1920) 253 U. S. 287. Ratemaking in the United States has variously been held to be a legislative or judicial "function." This is obviously due to the failure to distinguish between ultimate objective and method of procedure. In Village of Saratoga Springs v. Saratoga Gas, Electric Light \& Power Co., (1908) 191 N. Y. 123, the Court of Appeals of New York was clearly aware of the distinction, though, strangely enough, it seems to have escaped the same court in People ex rel. Central Park, N. \& E. River R. Co. v. Willcox, (1909) r94 N. Y. 383.

Protection of civil liberties is exemplified by the attitude of the courts in matters of exclusion and deportation of persons alleging citizenship. In exclusion cases a fair hearing before the administrative authorities is sufficient. United States v. Ju Toy, (1905) 198 U. S. 253; Chin Yow v. United States, ( 1908 ) 208 U.S. 8. But in case of deportation, due process seems to require that the administrative finding be subject to redetermination in the courts. $\mathrm{Ng}$ Fung Ho v. White, (1922) 259 U.S. 276. 
tional or statutory limitations, the courts, because of the usurpation, can redress potential and actual injuries through preventive or restitutional relief, without reviewing the act. Nor is the power of the courts to intervene in this case restricted to acts which are judicial in nature. In regard to the latter, jurisdictional grounds for relief can be tested upon direct attack. ${ }^{20}$ However, the available collateral methods of attack, particularly applications for injunctions, ${ }^{21}$ allow judicial inquiry into jurisdictional defects in a much more general sense. The possible extent of judicial protection in case of usurpation or excess of power depends entirely upon the content given by the courts to the term "jurisdiction." 2

The flexible limits of due process of law and of jurisdiction embrace a large area within which the right to judicial relief in the United States can be asserted against illegal and arbitrary administrative action. ${ }^{23}$ This remains so even in the face of the recent declaration of the United States Supreme Court that "the range of issues open to review is narrow," and that "Only questions affecting constitutional power, statutory authority and the basic prerequisites of proof can be raised." ${ }^{24}$

In the comparison of ordinary court control of administrative action in the destroyed French democracy and the United States, the similarities of the two systems should

${ }^{20}$ Certiorari or statutory appeal if appropriately worded.

${ }^{21}$ The remedy of injunction is of especial importance in the federal courts, which do not have power to grant common-law certiorari.

${ }^{22}$ How it may affect the scope of review is well illustrated by the doctrine of jurisdictional facts, chap. V, p. 70. Crowell v. Benson, (1932) 285 U. S. 22 ; cf. Borgnis v. Falk Co., ( 19 I I ) 147 Wis. 327 .

${ }^{28} \mathrm{Cf}$. Albertsworth, "Judicial Review of Administrative Action by the Federal Supreme Court," 35 Harv. L. Rev. (1922) 127, suggesting in the conclusions that review may be narrowed (I) to cases of the violation of the minimum of due process of law, and (2) to action occurring "outside the sphere of jurisdiction."

${ }^{2}$ Rochester Telephone Corp. v. United States, (r 939 ) 307 U. S. 125 at r39-140. 
not be permitted to eclipse obvious dissimilarities. Nevertheless it may at once be observed that the latter are differences in degree and method rather than in principle. Undoubtedly the power of the ordinary courts of France in regard to administrative action was less general and less broad than the corresponding power of the American courts. In France this power was always subject to be tested and its scope to be redetermined in the Tribunal des conflits, while in the United States courts are guided by self-imposed limitations under elastic constitutional precepts. In this respect the French system has had the advantage of machinery specially designed for the weighing of conflicting public and private interests by an impartial umpire. Procedurally, the methods of securing relief through the judicial courts under

- the French system were limited to collateral attacks. Executory administrative orders could be disregarded by the courts if clearly ultra vires, while redress for injuries sustained was available through actions for damages and restitution or injunctions against continuing administrative trespass. Direct attacks upon administrative acts in the ordinary courts of France were precluded because of the peculiar interpretation of the separation of powers.

Bearing in mind that administrative law developments in the United States and in former France have been overshadowed throughout by the respective conceptions and interpretations of the separation of powers, one of the recent demands voiced by the American Bar Association deserves analysis and rectification within these conclusions. In 1936 the Special Committee on Administrative Law of the Association, championing the separation of powers doctrine, ${ }^{25}$ objected vehemently to the so-called commingling of powers in administrative agencies. Relying upon language of

${ }^{25} 6$ 1 $\operatorname{Rep} . A$. B. A. (1936) 720 at 725 . See also Ballantine, "Administrative Agencies and the Law," $24 A . B . A$. J. (1938) I09 at 111. 
O'Donoghue v. United States, ${ }^{26}$ a Supreme Court decision, the Committee insisted that "it is precisely this forbidden commingling of the essentially different powers of government in the same hands that is today the identifying badge of an administrative agency." ${ }^{27}$ However, it should be noted that the Supreme Court in that case had before it the questions of "permanent tenure of office and the undiminishable character of the compensation of judges." ${ }^{28}$ Relating the issue to the separation of powers, the court made reference to "occasional . . . conferring upon a given department [of] certain functions, which, by their nature, would otherwise fall within the general scope of the powers of another." ${ }^{29}$ The particular instance envisaged was the enstrusting by Congress to the District Court of the District of Columbia ${ }^{30}$ of certain administrative functions that did not require the district court to act simultaneously as administrator and judge. The effect of the act of Congress on the contrary was that the court might act as the one in a given matter, and as the other in a different and unrelated cause. The evil thus referred to by the Supreme Court was not at all the same as the one emphasized by the American Bar Association Committee. For the latter complained about the commingling of "powers" in an administrative agency for purely administrative ends, that is, the exercise of differentiated "powers" for the accomplishment of a single administrative objective. Therefore the Committee's objection to the commingling of powers is open to criticism if it is given the general interpretation of which it is certainly susceptible.

${ }^{2}$ (1933) 289 U. S. 516 at 530.

${ }^{27} 6$ I Rep. A.B.A. at 727 . [Italics supplied.]

${ }^{28}$ O'Donoghue v. United States, (I 933 ) 289 U. S. 516 at 529-530.

${ }^{20}$ Ibid., 289 U. S. at 530.

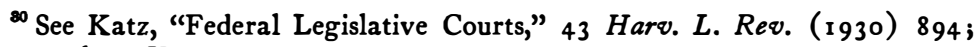
supra, chap. V. 
Except in the case of official action only nominally administrative and in fact judicial in nature, ${ }^{31}$ original adminis[trative action, i.e., the administrative process, is necessarily complex. It has, unavoidably, qualities closely resembling the traditional legislative and judicial processes. But, are these qualities "functions" or "powers"? Are they not merely different aspects of one of the essential forms of governmental activity, so that any permanent dissection must inevitably disintegrate and cripple that activity? Perhaps the viewpoint taken by a French writer is helpful in this connection. Hauriou, ${ }^{32}$ distinguishing the acts of the administration active from those of the juridiction administrative, has said that private persons, even though their rights may be affected, are third parties as regards original action by administrative agencies. Expressed in terms more familiar to the American lawyer, original administrative action that collides with private rights does not for this reason alone present a "case or controversy." ${ }^{33}$ Consequently an administrative agency engaged in fact-finding for the purpose of determining a course of action ultimately affecting private interests does not exercise "judicial functions or powers." ${ }^{34}$ Its action, in certain phases, indeed resembles or must conform to the methods customarily employed by judicial bodies; however there is no usurpation of powers which should be restored to their constitutional recipient. ${ }^{35}$ The individual

${ }^{\mathbf{2 1}}$ For instance, the action of a workmen's compensation tribunal or the judicially conducted review by an "administrative court" such as the Board of Tax Appeals, Court of Claims or Court of Customs and Patent Appeals.

*2 See Hauriou, Précis de droit administratif, roth ed. (1921), pp. 36-37, 361, 363. Cf. Jèze, Les principes généraux du droit administratif, 3d ed. (1925), pp. 7, $25 \mathrm{ff} ., 48 \mathrm{ff}$., making the distinction between actes juridiques and actes juridictionnels.

${ }^{38}$ See Prentis v. Atlantic Coast Line Co., (1908) 21 I U. S. 2 1 0 at $227-228$; Upshur County v. Rich, ( 1890 ) I 35 U.S. 467 ; Postum Cereal Co. v. California Fig Nut Co., (1927) 272 U. S. 693.

${ }^{a}$ Cf. People ex rel. Steward v. Board of Railroad Commissioners, ( 1899 ) I60 N. Y. 202 at 206-7.

${ }^{36}$ Cf. Norwalk Street Railway Company's Appeal, (1897) 69 Conn. 576 at $594-595$. 
phases of action are but integral parts of the administrative process; the fact that they follow a pattern common to other governmental activities does not automatically convert them into functions constitutionally belonging to another department. Therefore, as a necessary consequence of the separation of powers these so-called judicial functions could not be imposed upon the courts. ${ }^{36}$ Nevertheless, the danger of "administrative absolutism" is remote. For, if the composite administrative act is in any sense or phase illegal, judicial review and relief will effectively protect adversely affected private interests.

These considerations are important because of their bearing upon administrative law reforms proposed in the United States. Clearly, the administrative process is essential to modern government and must not be disintegrated. Where safeguards are needed to preserve our constitutional form of government they should first be provided in the administrative process itself. In other words, the administrative process must be constructed so as to conform uniformly to the constitutional due process requirements. The formulation of satisfactory procedure for the guidance of properly manned administrative agencies is the most important step towards judicious rather than judicial administration. The large extent to which judicial vetoes of administrative acts have signified an insistence upon due process has actually resulted in shifting the focus of interest from judicial review and its scope to administrative procedure.$^{37}$ However, it must not be assumed that the institution of judicial review of the completed administrative act may thus lose importance. The

${ }^{*}$ Federal Radio Commission v. General Electric Co., (1930) 281 U. S. 464; (see chap. V, note 7 , supra). Cf. Hodges v. Public Service Commission, (1931) I 10 W. Va. 649; Murray's Lessee v. Hoboken Land \& Improvement Co., ( 855 ) 18 How. ( 59 U. S.) 272 at 284; Fuchs, "Concepts and Policies in AngloAmerican Administrative Law Theory," 47 Yale L. J. (1938) 538 at 553; $61 \operatorname{Rep} . A . B . A$. at 728 ; chap. $\mathrm{V}$, supra.

${ }^{\text {S7 }}$ See the monographs prepared by the Attorney General's Committee on Administrative Procedure. 
scope may indeed contract ${ }^{38}$ and administrative activity may flow more freely. But judicial protection of constitutional rights and liberties must continue as an indispensable part of our existing form of government.

The comparison of the French and American administrative systems can be summed up with a concluding observation which current events have endowed with unforeseen significance. Not only in this country, but also under the droit administratif, as it has evolved, administrative action directly encroaching upon private rights and liberties was normally subject to ordinary court review and control. In its final setting the function of the French administrative courts

- was to accord expert treatment to intrinsically administrative problems rather than to subtract from the powers customarily belonging to the judicial courts.

Thus, in order that the circle may close, this inquiry must turn once more to the separation of powers. Both in the United States and in France a century and a half ago the establishment of a democratic form of government occurred under the auspices of the separation of the departments of government. However, the events following in the wake of widely diverging interpretations show that the precept was too vague to be depended upon for the preservation of the system it had helped to create. Each system developed within itself and of its own strength the far more reliable device known as judicial review. It is not difficult in this country

${ }^{88}$ The proposal in the new Administrative Law Bill, S. 915, H. R. 4236, 76th Cong., Ist sess. (1 939), favoring a considerable extension of judicial review of administrative orders and decisions undoubtedly exaggerates the function of judicial review. Section 5 (a) of the bill provides seven grounds upon which decisions may be set aside. Briefly stated, they are: (I) erroneous findings of fact, (2) insufficient evidence, (3) absence of facts to support the decisions, (4) lack of due process, (5) lack of jurisdiction, (6) unconstitutionality and illegality under federal laws, and (7) other illegality. 
to mistake the shadow for the substance, since the separation of powers as originally conceived placed no serious obstacle in the path of judicial control over administrative action. However, in France, where its corollary, the differentiation of agencies, had guaranteed autonomy to the administrative department, the struggle of "judicial review" to regain and maintain its place throws into high relief the reasons for such review, that is, the preservation of democratic institutions and the protection of civil liberties and private enterprise. 


\section{Bibliography}

\section{Texts and Articles on French Law Cired:}

Texts:

Appleton, Jean, Traité élémentaire du contentieux administratif, Paris, 1927, with 1936 Supplement.

Artur, E., De la séparation des pouvoirs et de la séparation des fonctions de juger et d'administrer, Paris, I905 [first published in Revue de droit public I 900, 1902, 1903$13: 214,470 ; 14: 34,236,436 ; 17: 78,234,439$, $18: 415]$.

Aucoc, Léon, Conférences sur l'administration et le droit administratif, 3 d ed., Paris, 1885 (2 vols.).

Berthélemy, H., Traité élémentaire de droit administratif, $13^{\text {th }}$ ed., Paris, 1933.

Bonnard, Roger, Le contrôle juridictionnel de l'administration, Paris, 1934. [Bibliothèque de l'institut international de droit public: No. VI.] Précis de droit administratif, Paris, 1935.

Brissaud, Jean, A History of French Public Law, translation by James W. Garner, The Continental Legal History Series, Boston, 1915.

Cormenin, L. M. de, Droit administratif, 5th ed., Paris, 1840 ( 2 vols.).

Dareste, Pierre, Les voies de recours contre les actes de la puissance publique, Paris, I9I4.

Ducrocq, Th., Cours de droit administratif, 7th ed., Paris, 1897-1905 (7 vols.).

Duguit, Léon, Etudes de droit public, Paris, 1901, 1903 (2 vols.).

Les transformations du droit public, Paris, 191 3; English translation: Law in the Modern State, translation by Frida and Harold Laski, New York, I 919.

Manuel de droit constitutionnel, 3d ed., Paris, 1918. Traité de droit constitutionnel, $2 \mathrm{~d}$ ed., Paris, 19211925 (5 vols.). 
Duguit, Léon and Monnier, Henry, Les constitutions et les principales lois politiques de la France depuis 1789, 4th ed., Paris, 1925.

Esmein, A., Cours élémentaire d'histoire du droit français, I I th ed., Paris, I 9 I 2.

Eléments de droit constitutionnel français et comparé, 7th ed., Paris, I 92 I ( 2 vols.).

Précis élémentaire de l'histoire du droit français de I 789 à I 8 I 4, Paris, 1908.

Hauriou, M., Précis de droit administratif et de droit public, Ioth ed., Paris, I92 I, I 2th ed., Paris, I 933.

La jurisprudence administrative de 1892 à 1929, Paris, I 929 ( 3 vols.) [a collection of the author's numerous case notes].

Jacquelin, René, Les principes dominants du contentieux administratif, Paris, I 899.

Jèze, Gaston, Les contrats administratifs, Paris, 1927.

Les principes généraux du droit administratif, $3 \mathrm{~d}$ ed., Paris, 1925.

Laferrière, E., Traité de la juridiction administrative et des recours contentieux, 2d ed., Paris, 1896 (2 vols.).

Montesquieu, Baron de, De l'esprit des lois, Pourrat ed., Paris 1834; English translation by Thomas Nugent, 1766, reprinted, London, 1823 .

Moreau, F., Le règlement administratif, Paris, 1902.

Teissier, G., La responsabilité de la puissance publique, Paris, I 906.

Waline, Marcel, Manuel élémentaire de droit administratif, Paris, 1936.

White, James, Speeches of M. de Mirabeau, the Elder, Pronounced in the National Assembly of France, translation, London, 1792.

Articles:

Barthélemy, J., "L'influence de l'ordre hiérarchique sur la responsabilité des agents," 3 I R. D.P. (I9I4) 49 I.

Berthélemy, H., "De l'exercice de la souveraineté par l'authorité administrative," 2 I R. D. P. (I 904) 209.

Duez, Paul, "Le contrôle juridictionnel de la constitutionalité des lois en France," Mélanges Maurice Hauriou, Paris, 1929, p. 2 I I. 
Duguit, L., "The French Administrative Courts," 29 Pol. Sci. Q. (I914) 385 (English translation).

Garner, James W., "French Administrative Law," 33 Yale L. J. (1924) 597.

"Judicial Control of Administrative and Legislative Acts in France," 9 Am. Pol. Sci. Rev. (I915) 637. Jacquelin, R., "L'évolution de la procédure administrative," 19R.D.P. (1903) 373; 20 R. D.P. (1903) 5. Laroque, P., "Les conflits d'attributions," $49 R$. D. $P$. (1932) 5 .

Réglade, M., "L'exception d'illégalité en France," 40 R. D.P. (1923) 393.

Waline, M., "Observations sur la gradation des normes juridiques établie par M. Carré de Malberg," 5 I R. D.P. (1934) 521 .

"Vers un reclassement des recours du contentieux administratif?" 52 R. D. P. (1 935) 205.

[Note: This list does not include the numerous annotations and comments to the cases which are referred to in the text.]

II. Other French Materials Used:

Encyclopedic works:

Répertoire général alphabétique du droit français, with Supplément (Fuzier-Herman), Paris, r 886-.

Répertoire méthodique et alphabétique de législation, de doctrine et de jurisprudence, and Supplément (Dalloz), Paris, I 845-I 897.

Répertoire pratique de législation de doctrine et de jurisprudence, and Supplément (Dalloz), Paris, I9I0-.

Codes and collections of statutes:

Code administratif (Petite collection Dalloz), Paris, [1932?]-1936.

Code civil, annoté, with Supplément (FuzierHerman).

Code d'instruction criminelle et code pénal (annotated, Petits codes Carpentier), Paris, I927.

Collection complète des lois, décrets, etc. (Duvergier), Paris, I 824-. 
Collections of, cases:

Dalloz, Recueil hebdomadaire de jurisprudence, Paris, 1924一.

[Annual volumes (since 1924) of the weekly reports of decisions not published in the Recueil périodique. (The decisions are accompanied by brief remarks.)]

A case cited (e.g.) D. H. 1926.427, indicates the report in this collection (Dalloz hebdomadaire) by year and page number.

Dalloz, Recueil périodique et critique de jurisprudence, de législation et de doctrine, Paris, I 845-.

[The annual volumes are divided into four (through I9I 5 five) parts. Part I contains decisions of the Cour de cassation; part 2, decisions of the courts of appeal and lower courts; part 3, decisions of the Counseil d'État and the Tribunal des conflits. These are selective reports of decisions and are annotated and frequently accompanied by signed comments and notes. Part 4 is reserved for the report of laws and statutes enacted during the year, supplemented with the pertinent legislative reports and debates. (Part 5 contained summaries of less important decisions of various tribunals.)]

Cases reported in this collection are cited (e.g.) D. I 929.3.144, i.e. Dalloz, I 929 volume, part 3, page 144.

Sirey, Recueil général des lois et des arrêts (Journal du palais)

[Annual volumes divided into four parts containing (I) decisions of the Cour de cassation, (II) decisions of the courts of appeal and lower courts, (III) decisions of administrative courts and the Tribunal des conflits, (IV) decisions of foreign courts. (Part IV was added in 1927, and prior to 1881 parts II and III combined formed part II of each volume.) The selected 
decisions which are annotated and in many instances accompanied by signed notes and comments are followed by laws and statutes in chronological order of enactment.]

Citations of cases in this collection are preceded by S. (Sirey) and give the number (year) of the volume, of the part and page, e.g., S. I 934.2.77.

Gazette du Palais, Paris, I $88 \mathrm{I}$ -

[Annual or semi-annual volumes of decisions (approximating chronological order) of the various judicial and administrative courts, with brief notes; followed by laws and statutes as enacted. The pages of each volume are numbered consecutively.]

Cases in this collection are cited, e.g., Gaz. Pal. 1935.1.781, thus indicating page 78I of the first semi-annual volume of $\mathbf{I} 935$.

Recueil des arrêts du Conseil d'État-des decisions du Tribunal des conflits (etc.), Paris, I $82 \mathrm{I}$ -

[Annual volumes containing the decisions of administrative courts and the Tribunal des conflits.]

Cases in these reports are identified by year and page number, e.g., Rec. I 898.573 .

[Note: Many of the more important decisions are reported in more than one of the foregoing collections.]

Revue du droit public et de la science politique, Paris, I 894-.

[A quarterly review in which leading articles concerning questions of public law are currently published, as well as abstracts of the important decisions and the notes accompanying them.]

Materials in the review (abbreviated R. D. P.) are cited by indicating number of yearly volume, year, and page, e.g., 46 R. D. P. ( 1929 ) 157. 
III. Miscellaneous Texts and Articles on Foreign Law Cited:

Texts:

Andersen, Poul, Ungültige Verwaltungsakte, translated into German from the Danish by Walther Pappenheim, Berlin, 1927.

Bernatzik, Edmund, Rechtsprechung und materielle Rechtskraft, Vienna, I 886.

Ghose, N., Comparative Administrative Law; Tagore Law Lectures, I918, Calcutta and London, I 9 I 9.

Jellinek, Georg, Allgemeine Staatslehre,-3d ed., Berlin, 1929. Gesetz und Verordnung, Freiburg, i. B., 1887.

Jellinek, Walter, Verwaltungsrecht, 2d ed., Berlin, 1929.

[Enzyklopädie der. Rechts- und Staatswissenschaft, No. XXV.]

Kelsen, Hans, Hauptprobleme der Staatsrechtslehre, 2d ed., Tübingen, I 923.

Kormann, Karl, System der rechtsgeschäftlichen Staatsakte, Berlin, I9Io.

Locke, John, An Essay Concerning Civil Government, reprinted in Boston, 1773.

Two Treatises of Government, London, 1698.

Mayer, Otto, Deutsches Verwaltungsrecht, 2d ed., Munich \& Leipzig, I 914 (2 vols.). [Vol. VI of Binding, Karl, Systematisches Handbuch der Deutschen Rechtswissenschaft].

Stein, F., Grenzen und Beziehungen zwischen Justiz and Verwaltung, Tübingen, I 912.

Articles:

Gordon, D. M. "Administrative Tribunals and the Courts," 49 L. Q. Rev. (1933) 94, 4 I9.

Jellinek, Georg, "Eine neue Theorie über die Lehre Montesquieu's von den Staatsgewalten," 30 Zeitschrift für das Private-und Öffenliche Recht der Gegenwart, (1903) 
IV. Texts and Articles on American Law Cited:

Texts:

Dickinson, John, Administrative Justice and the Supremacy of the Law in the United States, Cambridge, Mass., 1927.

Erlick, E. M., La séparation des pouvoirs et la convention fédérale de 1787 , Paris, 1926.

Federalist, The [written in 1788; same chapter numberings in all editions].

Freund, Ernst, Administrative Powers over Persons and Property, Chicago, 1928.

The Police Power, Chicago, 1904.

Landis, James M., The Administrative Process, New Haven, 1938.

Articles:

"Administrative Action as a Prerequisite of Judicial Relief," 35 Col. L. Rev. (1 935) 230.

Albertsworth, E. F., "Judicial Review of Administrative Action by the Federal Supreme Court," 35 Harv. L. Rev. ( I92 I) 127.

Ballantine, Arthur A., "Administrative Agencies and the Law," 24 A.B.A.J. (1938) ro9.

Berger, Raoul, "Exhaustion of Administrative Remedies," 48 Yale L. J. ( I 939) 981.

Beutel, Frederick K., "Valuation as a Requirement of Due Process of Law in Rate Cases," 43 Harv. L. Rev. (1930) 1249.

Borchard, Edwin M., "Declaratory Judgments in Administrative Law," i I N.Y.U. L. Q. Rev. ( I 933) I 39.

[Note] 39 Col. L. Rev. (I 939) 693.

Cooper, Robert M. "Administrative Justice and the Role of Discretion," 47 Yale L. J. (1938) 577.

Dickinson, John, "Crowell v. Benson: Judicial Review of Administrative Determinations of Questions of 'Constitutional Fact," " 8o U. Pa. L. Rev. (I 932) 1055.

Fairlie, John A., "The Separation of Powers," 2 I Mich. L. Rev. (1923) 393.

Fuchs, Ralph F., "Concepts and Policies in Anglo-American Administrative Law Theory," 47 Yale L. J. (1938) 538. 
Isaacs, Nathan, "Judicial Review of Administrative Findings," 30 Yale L. J. ( I92 I) 78I.

Jacoby, Sidney B., "Delegation of Powers and Judicial Review: A Study in Comparative Law," 36 Col. L. Rev. ( 1936) 87 I.

Jaffe, Louis L., "Invective and Investigation in Administrative Law," 52 Harv. L. Rev. (1939) 1201.

Jaretzki, Alfred, Jr., "The Administrative Law Bill: Unsound and Unworkable," 2 La. L. Rev. (I 940) 294.

Jennings, E. G., "Tort Liability of Administrative Officers," 2 I Minn. L. Rev. (1936) 263.

"Judicial Control of Administrative Agencies in New York," 33 Col. L. Rev. (1933) 105.

Katz, W. G., "Federal Legislative Courts," 43 Harv. L. Rev. (I930) 894 .

Kirchwey, Karl W., "The Interstate Commerce Commission and the Judicial Enforcement of the Act to Regulate Commerce," I4 Col. L. Rev. (I9I4) 2 II.

Landis, James M., "Administrative Policies and the Courts," 47 Yale L. J. (1938) 519.

McAllister, Breck P., "Administrative Adjudication and Judicial Review," 34 Ill. L. Rev. (1940) 680.

McGuire, O. R., "The American Bar Association's Administrative Law Bill," I La. L. Rev. (I 939) 550.

Parker, Edmund M., "State and Official Liability," I9 Harv. L. Rev. ( I 906) 335 .

"A Redefinition of Judicial Review of Administrative Orders," 48 Yale L. J. (1 939) I 256.

Sharp, Malcolm P., "The Classical American Doctrine of 'The Separation of Powers'," 2 U. Chi. L. Rev. (1935) 385 .

Special Committee on Administrative Law, American Bar Association Reports, vol. 61 (1936), p. 720; vol. 62 (1937), p. 789; vol. 63 (1938), p. 331; Advance Program (1938), p. I 34 .

Stason, E. Blythe, "Methods of Judicial Relief from Administrative Action," 24 A. B. A. J. (1938) 274.

Symposium, "American Bar Association's Administrative Law Bill," 34 Ill. L. Rev. (1940) 64 I. 


\section{Index}

Abuse of power, I I6-I I 8 .

Actes de gestion, see Acts of management.

Actes de puissance publique or actes d'autorité, see Authoritative acts. Acts of management and authoritative acts, distinction, 39 ; jurisdictional implications, 40, 4I, 5354, 61 .

Administration active, distinguished from juridiction administrative (administrative courts), 20, $21-$ 22; acts of, censure through annulment, 34 .

Administrative absolutism, judicial safeguards in France, 1 77-1 78; protection against, does not require disintegration of administrative process, 187 .

Administrative action, effect of delay, 37; object of, distinguished from method, I79-180, I $81-$ I 82; when deemed "judicial," I 80-181. See also Administrative process; "Judicial."

Administrative acts, nonreviewability in America, basis, 65-67; of general application, 93; of individual application; 93 ; effect of illegality, I39-14I ; "nonexistent," I 40; what are, 66, 80-83, 142.

Administrative appeals, 33; provision in Walter-Logan Bill, 73. See also Recourse for excess of power.

Administrative autonomy, area of in America, $68-74$; role of judiciary in relation to, $73-74$.

Administrative contracts, see Contracts.
Administrative courts, French, dispute whether control of administrative acts should be given to ordinary courts, 15-16, 102; general, limited and special jurisdiction, 16-18; in America, proposed by Logan Bill, 72-73; French, suppression of, proposed, 102; have no injunctive powers, 163; essential function, 188. See also Conseil d'Etat; Jurisdiction.

Administrative decisions, see $D \dot{e}$ cisions exécutoires.

Administrative discretion, check upon, see Administrative trespass, doctrine.

Administrative error (fault, mistake), see Faute de service.

Administrative execution, illegal, a form of trespass, 162 ; subject to redress in ordinary courts in France, 162-163; injunction against, 163 ; judicial authorization, when required, 164 ; judicial authorization, when not required, 164-169; in case of absence of statutory sanctions, I 64I68; in case of emergency, 162 , 168-169.

Administrative expertness, essential motive for creation of French administrative courts, 15-16, 188; bearing on distribution of jurisdiction, 41, 5I, 62; basis of judicial noninterference in America, 66-67; discretion of American courts to respect or disregard, $7 \mathbf{I}$.

Administrative finality, American doctrine, 69-71, 181; effect, 73 . 
Administrative functions, constitutional courts may not perform, 63-64.

"Administrative guarantee" of officers, 96-10 I ; effect on principle of differentiation of agencies, 97 ; scope, 98, 100-101, 108; sanctions, 99; operative only as to acts "related to function," I00-101; repeal, IOI-105. See also Administrative officers.

Administrative Law Bill, see Walter-Logan Bill.

Administrative law reforms, 72-74; must take account of discretionary powers of courts, 72-73; proposed by Logan Bill, 72 ; proposed by Walter-Logan Bill, 73; must envisage constitutional administrative procedure, 187 .

Administrative officers, redress for delictual acts, 93-94; prohibition of actions against, in France, 94; personal liability, 94-96; necessity of protection, against intimidation, 95, 97-98; criminal liability, 96; abuse of actions against, checked, 96; constitutional guarantee, 96-10I; repeal of guarantee, IOI-105; effect of repeal of guarantee, I05; substitution of "judicial" for administrative guarantee, 105-110. See also "Administrative guarantee"; Faute personnelle.

Administrative personnel, necessity for adequate training, 74 .

Administrative process, the, is necessarily complex, 186; must not be disintegrated, 186-187; resemblance to other governmental activities, not a usurpation of "functions," 187.

Administrative questions, what are, 65,66 . See also Constitutional courts.

Administrative regulations, what are,
$77-78$; powers of French courts relative to, 78, 86-89, 90, 177 ; l'exception d'illégalité relative to, 78-80, 82; legislative character, disputed, 80-83; administrative quality, 82 ; judicial declaration of illegality, not an annulment, 84, 93, effect, 85 , enforcement, 85 ; interpretation and invalidation, 87-88; affecting civil liberties and property rights, 89; legality, a question préjudicielle, 89; judicial control in America, 90; similarity of judicial control in France and America, 90; provisions in Food, Drug and Cosmetic Act, concerning review, 91-92.

Administrative systems, French and American, similarities, 62-64, 77, 90, I77-1 78, I 88 .

Administrative trespass, defined, I4I, 1 50-1 54; a criterion of jurisdiction, $142,147-148$; utility of concept, 148-150, 153; elasticity of concept, 149-150, 175 ; distinct from faute personnelle, 149, I 73-1 74; reasons for contemporary interest, 150; unconstitutionality and illegality, elements, I5I; procedural irregularity, I 50-I 53, I 75 ; violation of rights and liberties, 154 ; degree of invasion of rights and liberties, 154, 171-1 73; illegal administrative enforcement, 162, 164, I69-170; doctrine of, a check on administrative discretion, 170, 171 ; dispossession, 172 ; unlawful detention, 173; interference with religious freedom, 173 ; interference with freedom of the press, 173; concept, complicated nature, 1 74-1 76; function of doctrine, 175-1 76; operation of doctrine, I 75. See also Civil liberties and property rights.

Alembert, d', J. L. R., on Montes- 
quieu's conception of two governmental powers, 5-6.

American Bar Association, Special Committee on Administrative Law, misconceives French system of administrative justice, 20; on strict interpretation of the separation of powers, 23-24; demanding segregation of "judicial functions" of administrative agencies, 24; classification of "judicial functions" of administrative agencies, 67; negative inference concerning the supremacy of the law in France, rejected, 177; objection against "commingling of powers," 184-185; critique of objection, $185-187$.

Ancien régime, no immediate discard of institutions, 94 .

Annulment of administrative acts, see Recourse for excess of power.

Appleton, J., defining public service, 41 ; on l'exception d'illégalité, 80; on interpretation of the separation of powers, 86; defining faute personnelle, 125-126; on jurisdiction in case of faute personnelle, 126, 127; on judicial protection of constitutional liberties and property, 135.

Arrest, illegal, 143. See also Administrative trespass.

Assemblée constituante, Montesquieu's theory debated in, $\mathbf{I} 2$.

Aucoc, L., on the need for a central administrative court, 15 ; on ordinary jurisdiction over questions of civil and property rights, 134135.

Authoritative acts, distinguished from acts of management, 39-40. See also Acts of management.

Authorization of actions against administrative officers, see Administrative officers.

Berthélemy, H., disapproving extension of administrative jurisdiction, in damage actions, $48-49$, in actions on contract, 54 ; on repeal of "administrative guarantee," I IO; repudiating doctrine of administrative sanctions, 166-167, 169.

Bill of rights, in French constitution, 95,96 .

Blaevoet, Ch., reconsidering former repudiation of doctrine of administrative trespass, 148; on doctrine of administrative trespass as a protection against arbitrary action, 170.

Bonnard, R., defining administrative trespass, I 5 I-I 52.

"Case or controversy," 66, 91 ; original administrative action affecting private rights not a, 186 .

Civil liberties and property rights, doctrine of judicial protection in France, 89, 133-137, 188; ordinary jurisdiction where involved, statutory, 135, 136; doctrine of judicial protection, reasons advanced against, 1 36-137; invasion of, 154, 171-173; doctrine of judicial protection reconciled with differentiation of agencies, I 76. See also Administrative trespass.

Collateral attack on administrative acts, through actions against administrative officers, 108, III, 179; did not materialize in France, 112, I31; through actions against officers in America, I 3 I; as test of administrative jurisdiction, 179, 183; only method of obtaining ordinary court relief in France, 184.

"Commingling of powers," see American Bar Association.

Commissaire du gouvernement, I 8; importance of consulting conclusions, 43.

Commission $d u$ contentieux, see Conseil d'État, judicial section. 
Conclusions, see Commissaire $d u$ gouvernement.

Conflict, jurisdictional, see Confit. Conflit, implementation of differentiation of agencies, 25-27; unilateral power of administrative to assert, 25-26; positif, negatif, de décision, distinguished, 27; statutory exclusion in matters of personal liberty, 136, 142. See also Tribunal des conflits.

Conseil d'Etat, original character, 14-1 5, 49; expansion of jurisdiction, 15 ; establishment as an independent court, 16, 32; designates both administrative body and its judicial section, 17 ; organization and functioning, 17-18; consent to actions against administrative officers, 96-97. (See also Jurisdiction; Recourse for excess of power).

Conseil du roi, 9, 32.

Conseils de préfecture, jurisdiction, I6, 18 ; organization, 18.

Constitutional courts, American, may not determine administrative questions, 63-64, 72, 178-1 79, 187; rules of self-limitation, 68 , 178-179; protective function, I 33, I 37. See also Judicial review.

Constitutional facts, doctrine of, 6971 .

Constitutionality of administrative acts, $151,177,182-183$. See also Administrative trespass; Usurpation of power.

Constitutionality of laws, French courts without power to determine, 83 .

Constitutional limitations on review powers of American courts, I 78I 79.

Contentieux de l'annulation, 3 I. See also Recourse for excess of power.

Contentieux de la répression, 31 .

Contentieux de l'interprétation, 31 .
Contentieux de pleine juridiction, 31 . See also Ordinary recourse.

Contracts, jurisdiction in case of contracts pertaining to public service, 51, 56; when "administrative," 53 ; when made by central government, 53 , 55 ; predetermination of jurisdiction by special clauses, 56. See also Jurisdiction.

Cormenin, L. M., de, on administrative protection of officers, 99-100.

Cour de cassation, 26, 43, 79, 86, 88, 103, 104.

Court control of administrative acts, see Administrative courts; Judicial review; Jurisdiction.

Curia regis, 9.

Damage to land, 145. See also Administrative trespass.

Damages, actions for, against administrative officers, see Administrative officers; Collateral attack.

Dareste, P., on judicial protection of civil liberties and property, I 34, I35.

Décisions exécutoires, annulment upon recourse for excess of power, 36; defined, 36; requirement of notice, 36 ; requirement of proceeding by way of, sanctions, 37 .

Declaratory judgments, determination of questions préjudicielles in France, 89; on validity of regulations, proposed in America, 91.

Delegation of legislative power, theory of, rejected in France, 80; judicial invalidation of in America, 90.

Differentiation of agencies, administrative and judicial, in France, a corollary of the separation of powers, I 2; object, I 2-13 ; constitutional and statutory provisions, 13-14; strict interpretation held not practicable, 19 ; attenuation of principle, $20-21,23$, 39; sanctions of principle, 25-27, 89; administrative expertness a 
factor in interpretation, $4 \mathrm{I}$; nonstatutory exceptions to principle, 77 ; statutory exceptions to principle in case of regulations, 78 80 ; interpretation in regard to judicial control of administrative regulations, 80, 88, 177; interpretation in regard to jurisdiction over public officers, 94; effect of repeal of "administrative guarantee" of officers, 102 ; re-affirmation of principle, 105-107, I I I, I I ; faute personnelle doctrine not a limitation, I 30, I 3 I; conflict with doctrine of judicial protection of civil liberties and property, 89, 133-137, 138; principle deemed not violated by ordinary court review of "nonadministrative" acts, I41, I43; violation of principle by unauthorized application of administrative sanctions, 164 ; circumvention of principle by doctrine of administrative trespass, $175,176$. See also Separation of powers.

Direct attack on administrative acts, 3 I, I 8 3. See also Judicial review; Recourse for excess of power.

Dispossession, 167-168, 1 72-1 73 . See also Administrative trespass.

Droit administratif, see Administrative systems, French.

Ducrocq, Th., on Montesquieu's conception of the separation of powers, 7 ; on duty of courts to verify legality of administrative regulations, 78 ; on judicial protectorate over property rights and liberties, 134.

"Due process of law," I33; common to both American and French conception of justice, 177 ; requirement of procedural due process, $179-182,187$.

Duguit, L., on the two-fold nature of administrative regulations, $8 \mathrm{I}$; on l'exception d'illégalité, 82 ; on effect of superior order on personal liability of officers, 123124; defining faute personnelle, 124-125; on jurisdiction in case of faute incluse, 125.

Emergency, see Administrative execution.

Encroachment on private property, 146. See also Administrative trespass.

Évocation, withdrawal of jurisdiction from courts, II , 25, 95 .

Exception d'illégalité, 78-80. See also Administrative regulations.

Excès de pouvoir, see Excess of power.

Excess of power, what constitutes, 34 ; recourse, see Recourse for excess of power.

Exhaustion of administrative remedies, not a prerequisite to recourse for excess of power, 35; American doctrine, 68-69, 181 ; purpose of doctrine, 68 ; distinguished from "prior resort" doctrine, 68. Expropriation, 167-168.

Faute de service, and faute personnelle, distinction, 47, 100.

Faute détachable, see Faute personnelle.

Faute incluse, see Faute personnelle. Faute lourde, see Faute personnelle. Faute personnelle, distinguished from faute de service, 47, 100, I I2; deprives official act of administrative quality, 48 ; jurisdictional implications, I I 2, I1 3 ; liability of administrative officers, I 13 ; definition, I14; negligence, when faute personnelle, I $15-116$, $127,129,131$; abuse of power, 116-118; bad faith, 119, 126; faute lourde, 1 20-1 21 , 1 26 ; "detachable," distinguished from "inclosed," I 24, 125 ; "intellectually descernible," I 25, I 26; illegal act of enforcement not per se 
Faute personnelle (Continued) faute personnelle, 1 26; "third degree," 128; inaction, 130; doctrine has not broadened ordinary court control over administrative acts, 130; culpable intent chief element of concept, I 30-13 I, 1 57; distinct from trespass, 145, I 57, $173-174$.

Food, Drug and Cosmetic Act, provisions for judicial review of regulations, 91-92.

Freedom of the press, illegality of restrictive regulation, 79; curtailment of, deemed administrative error, I1 8; violation of, held a trespass, 147, 155-1 56, $172-$ I 73; violation of, by administrative seizure (of newspaper), 156 , 170 (of printed matter and printing equipment), 157-1 58.

"Fundamental rights," protection by constitutional courts, 133.

Hauriou, M., on décision exécutoire, 36; on gestion publique, 42 ; on rule of jurisdiction in matters of public service, 48 ; on jurisdiction in matters of contract, 56 ; on the "supremacy of the law," 83; on protection of administrative officers, 98; on repeal of "administrative guarantee," 103; defining administrative trespass, I 50-I 51 ; on administrative rule-making power and procedure, I5I; on administrative execution, I66, 167; on function of trespass doctrine, I 70; on original administrative action, 186 .

Illegality of administrative acts, basis of ordinary jurisdiction in France, 77, 96; degrees, 138, 139; does not automatically render act "non-administrative," I 38-1 39, 174-175; an element of trespass, I 47-I 48, I 50-1 53 . See also Administrative regulations; Ad- ministrative trespass; Usurpation of power.

Injunction, against illegal administrative execution in France, 163; not available in administrative courts, 163, 165; in America, a method of collaterally testing administrative jurisdiction, 183 .

\section{Intendants, 9.}

Interest, adversely affected, basis for recourse for excess of power, 33; reasons for requiring, 34 .

Interference, judicial, with administrative action, in France, 10-11; in America, 23-24. See also Parlements.

Jacquelin, R., on effect of repeal of "administrative guarantee," 102, 107, 109; repudiating doctrine of ordinary jurisdiction for protection of civil liberties and property, 134 .

Jèze, G., on prestige of French civil courts, 49; defining faute personnelle, I I 9-1 20.

"Judicial," term, used to differentiate administrative court review and administrative review, 20; meaning relative to administrative action, I 79-1 80, 181 .

Judicial control, see Court control.

Judicial power, Montesquieu's conception, 8; Montesquieu's conception favorable to aims of French Revolution, 8, 13 ; American constitutional conception, 22-23, 62-64; American doctrines of limitation upon, 63-69; normal scope, revival of interest in France, 138.

Judicial relief from administrative action, see Judicial review.

Judicial review, of administrative regulations, 88-92 ; of administrative acts, comparable with rules governing review powers of 
French civil courts, 177-1 83, 18 8; procedural devices in Americe, $178,179,183$; right to, content, 178-1 79, 182; limited by "judicial" nature of act, I 78179, I 81 ; scope, defined by purpose, 181 ; determined by interpretation of "due process" and "jurisdiction," 182-1 83; and the "supremacy of the law," I82; American and French methods, differ in degree only, 184 ; advantage of French system, I 84 ; in the sense of protection of constitutional rights, essential to American form of government, I88; indispensable to preservation of democratic institutions, 188-189.

Juridiction administrative, distinct from administration active, 20, 21-22.

Jurisdiction, exclusive, of Conseil d'État to annul administrative acts, $31-33$; in case of ordinary recourse, 39-42; in case of actions for damages, 42-50; in case of actions on contract, 50-56; in case of "administrative" contracts, 53-55; distribution among French courts, controlled by familiar ideas, 62; factors complicating, where administrative regulations involved, in France, $80-83$; of American courts over regulations, 90-92; of French courts over actions against officers, 94, 98; in case of faute personnelle, 112 ; in case of trespass, 122-123, 141-143; of French civil courts in matters of constitutional rights and property, 133-137; statutory, declaratory nature, in case of liberties and property, 136 ; in case of illegal administrative acts, 1 38-140, 177; in case of "non-administrative" acts, I4I, 142-143, I47-
148, 174-175; in case of illegal acts of execution, $162-163$; of American courts to review administrative acts, $178-183$.

Jurisdictional concepts, purpose of formulation in France, 61-62.

Jurisdictional conflicts, see Confit; Tribunal des conflits.

Jurisdictional facts, American doctrine, 69-7I.

Justice déléguée, 1 5-16.

Justice retenue, I I, I 5, 32.

Laferrière, $E$., on jurisdiction in case of ordinary recourse, 40, 52 ; on "administrative guarantee," 100, 10I; defining faute personnelle, I1 4; concerning violations of the freedom of the press, 118 ; on judicial protectorate over constitutional rights and liberties, 1 35, 147; on illegality of administrative acts, 138-139; on usurpation of power, 139-140.

Laroque, $P$., repudiating doctrine of administrative trespass, $\mathbf{1 4 8 .}$

Law schools, necessity of integrating public law curriculum, 74 .

Legality of administrative acts, see Declaratory judgments.

Legislative courts, federal, may perform nonjudicial functions, 64, 72 ; proposed "consolidation," 72.

Lettre de jussion, see Registration of royal ordinances.

Liability of administrative officers, a jurisdictional problem in France, 94, 112; established by Bill of Rights, 95-96; effect of "administrative guarantee" of officers, 97 ; complemented by state liability, I I I-I I 2, I 3 I; effect of superior order, 1 23; not involved in case of trespass, 174.

Lit de justice, I1. See also Registration of royal ordinances.

Locke, J., on the separation of powers, 5 . 
Logan Bill, federal administrative courts proposed, $\mathbf{7 2}$.

Maîtres des requètes, 17,43 .

Mandamus, precluded in France by differentiation of agencies, 37 . See also Judicial review, methods of.

Marchés de fournitures, 53, 55. See also Contracts.

Military requisition, irregular, 145.

Ministre-juge, doctrine of, 16.

Mirabeau, H. G. R., comte de, I.

Montesquieu, Ch. L. de S., baron de, conception of separation of powers re-examined, 4-8; reception of doctrine, in America and France, 5 ; recognized only two governmental "powers," 6; first to postulate distribution of governmental powers, 7; did not recognize a coordinate judicial power, 6-8.

Moreau, F., on interpretation of the differentiation of agencies, 8485.

"Negative order" doctrine, 65-66; repudiation of, as a criterion of reviewability of administrative acts, 65.

Negligence, see Faute personnelle. "Nonadministrative" nature of acts, a jurisdictional formula in France, I 38, I 4 I, 142-143, 147-148, $158,163,174,175$.

"Nonexistent" acts, 140-I 4I, 177. See also Administrative acts.

Notice, 36. See also Décisions exécutoires.

Notice and hearing, see Procedural irregularity.

Officers, see Administrative officers.

Ordinary courts, French, assertion of jurisdiction over administrative acts, 77, 88. See also Jurisdiction.

Ordinary recourse against administrative acts, in France, requisites, 38.
Parallel recourse, what is, 35 . See also Recourse for excess of power.

Parlements, powers, 9; interference with executive by, 9-I I.

Personal error (fault, mistake), see Faute personnelle.

Personal liability, see Liability of administrative officers.

Personal liberty, administrative interference, 143, 173.

Police power, exercise of in conflict with civil liberties, not trespass per se, I 59-161, I 70, 172 .

Prior resort to administrative action, 68-69; distinguished from "exhaustion" doctrine, 68.

Private interests, protection not in issue at inception of French administrative system, 14 .

Procedural due process, see "Due process of law"; Judicial review.

Procedural irregularity, a form of administrative trespass, 150-153, I75.

Property rights, see Civil liberties and property rights.

Public liberties, what are, 154.

Public service, jurisdictional implications of concept, 40-42, 59, 6I ; definition, $4 \mathrm{I}$; applied to damage actions, 42-50; applied to contract actions, 50-56; distinction of commercial and non-commercial, 56-6o.

Quasi-judicial action, see "Judicial." Questions préjudicielles, doctrine of, differentiation of agencies, sanction, 89, 145, 148-1 50. See also Declaratory judgments.

Rechtsïberzeugung, judicial protection of liberties and property, in France, 137.

Recours de pleine juridiction, see Ordinary recourse.

Recours gracieux, 33 .

Recours hiérarchique, 33. See also Administrative appeals. 
Recours parallèle, see Parallel recourse.

Recours pour excès de pouvoir, see Recourse for excess of power.

Recourse for excess of power, exclusive jurisdiction of Conseil d'Etat to receive, 31, 32, 36; significance, 3I-33; evolution, 32-33; nature of remedy, 33-35; originally an administrative appeal, 33; judicial aspect, 33, 37, 49; grounds, 34 ; is a proceeding in rem, 34; informal and inexpensive, 35 ; not available if parallel recourse open, 35 ; "executory decisions" subject to, 36 ; does not normally arrest administrative action, 37; evasion of by administrative, 37 .

Référé, see Injunction.

Registration of royal ordinances, power of parlements to refuse, of Crown to compel, I0-II.

Regulations, see Administrative regulations.

Religious freedom, administrative interference, I 44, 173. See also Administrative trespass.

Remonstrance, see Registration of royal ordinances.

Sanctions, administrative, See Administrative execution.

Section du contentieux, 15. See also Conseil d'État, judicial section.

Segregation of judicial functions, see American Bar Association.

Seizure, administrative, see Administrative trespass.

Séparation des autorités administrative et judiciaire, I 2. See also Differentiation of agencies.

Separation of powers, historic political meaning of doctrine, significance, 3-4, 23; function, 8, 12, 22, 23, 28; adoption in France, two-fold object, I 3-14; elasticity of doctrine, 19; difference in American and French conceptions of Montesquieu's theory, 21-23, $62-63,90$; changing content of doctrine, 23-24; implementation of, 25-27; interpretation by United States Supreme Court, 6368 ; instrumental in establishment of American and French democratic governments, 188 . See also Differentiation of agencies; Montesquieu.

Service public, see Public service. State liability, adoption in France, I I I; basis, I I I-I I 2; advantage, 112.

Supersedeas, 37.

"Supremacy of the law," the, I 33; postulate common to American and French administrative systems, 177; American Bar Assoçiation, inference, concerning, rejected, 177 ; implementation with judicial review, 182.

Torts, see Administrative officers; Faute de service; Faute personnelle.

Trespass, see Administrative trespass.

Tribunal des confits, organization and function, 26; establishment, 105 ; respect enjoyed, 108.

Usurpation of power, what constitutes, 139-141; distinct from excess of power, 140; a form of trespass, 150.

Voie de fait, see Administrative trespass.

Waline, M., defining administrative trespass, 154; defining "public liberties," I 54 ; on administrative execution, 162, 171 .

Walter-Logan Bill, provisions for intra-agency review, 73; proposals concerning review of administrative regulations, 90-91; proposals concerning judicial review, 188. 